\author{
UNIVERSIDADE DE SÃO PAULO \\ FACULDADE DE ARQUITEURA E URBANISMO
}

EVANIZA LOPES RODRIGUES

\title{
A Estratégia Fundiária dos movimentos populares na produção autogestionária da moradia
}




\section{A Estratégia Fundiária dos movimentos populares na produção autogestionária da moradia}

Dissertação apresentada à faculdade de Arquitetura e Urbanismo da Universidade de São Paulo para a obtenção do título de Mestre em Arquitetura e Urbanismo Area de Concentração: Habitat Orientadora: Profa. Dra. Raquel Rolnik

EXEMPLAR REVISADO E ALTERADO EM RELAÇÃO À VERSÃO ORIGINAL, SOB RESPONSABILIDADE DO AUTOR E ANUÊNCIA DO ORIENTADOR.

O original se encontra disponível na sede do programa

São Paulo 10 de junho de 2013

São Paulo 
AUTORIZO A REPRODUÇÃO E DIVULGAÇÃO TOTAL OU PARCIAL DESTE TRABALHO, POR QUALQUER MEIO CONVENCIONAL OU ELETRÔNICO, PARA FINS DE ESTUDO E PESQUISA, DESDE QUE CITADA A FONTE.

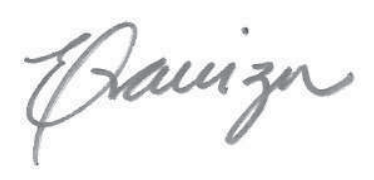

E-MAIL AUTORA: evaniza@uol.com.br

Rodrigues, Evaniza Lopes

R696e A estratégia fundiária dos movimentos populares na produção autogestionária da moradia / Evaniza Lopes Rodrigues. -- São Paulo, 2013.

233 p. : il.

Dissertação (Mestrado - Área de Concentração: Hábitat) FAUUSP.

Orientadora: Raquel Rolnik

1.Habitação popular 2.Solo urbano 3.Movimentos sociais Urbanos - Brasil I.Título 
Nome: RODRIGUES, Evaniza Lopes

Título: A Estratégia Fundiária dos movimentos populares na produção autogestionária da moradia

Dissertação apresentada à Faculdade de Arquitetura e Urbanismo da Universidade de São Paulo para a obtenção do título de Mestre em Arquitetura e Urbanismo, na Área de Concentração Hábitat.

Aprovada em:

Banca Examinadora

Prof. Dr. Instituição:

Julgamento: Assinatura:

Prof. Dr. Instituição:

Julgamento: Assinatura:

Prof. Dr. Instituição:

Julgamento: Assinatura: 


\section{Dedicatória}

Aos militantes dos movimentos de moradia que insistem em acreditar, ocupar, construir e anunciar a boa nova em nossas cidades. 


\section{Agradecimentos}

Aos lutadores e lutadoras do Movimento Sem Terra Leste 1, meu chão de vivência e construção, da União dos Movimentos de Moradia, da União Nacional por Moradia Popular, do Fórum Nacional de Reforma Urbana, da Secretaria Latino Americana de la Vivienda Popular e da Coalizão Internacional do Habitat e das assessorias técnicas, pelo aprendizado diário e por não permitirem, nunca, o desânimo ou a desistência.

À minha mãe que plantou em mim a semente da justiça social e da solidariedade.

Ao meu companheiro de vida e de luta Edilson Mineiro, por partilhar os dias de vida, de ocupação, de mutirão e de inúmeras reuniões, as angústias e belezas da vida.

A Guilherme Reinhard, Henrique Pacheco, Etel Costa, Emir Rigon, Rosangela Paz, Raquel Rolnik e Olívio Dutra que, ao longo da vida, me ajudaram a traduzir indignação em ação e reflexão.

Ao companheiro Jorge Hereda, com quem tenho compartilhado a experiência de executar a política, com seus limites e possibilidades.

A Nabil Bonduki, Pedro Arantes e Luciana Lago que insistiram que eu colocasse, na reflexão acadêmica, anos de vida e de luta. 
Tomem posse da terra e habitem nela, pois eu lhes dei essa terra, para que vocês a habitem. Dividam a terra entre vocês. Deem como herança uma parte maior para aquele que é mais numeroso, e uma parte menor para aquele que é menos numeroso.

Livro dos Números, 33:53-54 


\section{RESUMO}

RODRIGUES, Evaniza Lopes. A Estratégia Fundiária dos movimentos populares na produção autogestionária da moradia. 2013. 233 f. Dissertação (Mestrado) - Faculdade de Arquitetura e Urbanismo, Universidade de São Paulo, São Paulo, 2013.

Os movimentos populares de luta por moradia, que defendem a proposta autogestionária, atuam no Brasil desde a década de 80 , e são protagonistas da recente construção legal e institucional da política urbana e habitacional brasileira. Os programas Crédito Solidário e Minha Casa Minha Vida Entidades, frutos de uma trajetória de mobilização e pressão desses movimentos, reconhecem a atuação de entidades sociais, cooperativas e movimentos populares como agentes promotores de empreendimentos habitacionais, com recursos públicos federais.

O acesso à terra urbanizada e bem localizada para a habitação popular tem estado na pauta dos movimentos de reforma urbana que para isso têm desenvolvido ações diretas, como ocupações e mobilizações públicas, iniciativas legislativas e ações institucionais, como a participação em conselhos de políticas públicas. Entretanto o conjunto de instrumentos colocados à disposição da sociedade para regular o uso do território ainda não foram efetivamente implantados. Assim, a ausência de política fundiária, em nível local e nacional aliada à abundância de recursos públicos e privados disponíveis para o setor da construção civil e a financeirização da produção da moradia e da cidade fazem com que a busca por áreas disponíveis para a produção habitacional de interesse social seja cada vez mais difícil. Tal tarefa se torna ainda mais árdua para os movimentos sociais. O Programa Minha Casa Minha Vida consagra um modelo de produção habitacional calcada em um modelo único de acesso, através da aquisição, ainda que com subsídios expressivos, da propriedade individual da casa, que se torna, imediatamente, produto de mercado, com um aparato normativo adequado a esse objetivo. Configura-se assim um conflito entre a proposta de política habitacional autogestionária formulada no âmbito dos movimentos e as condições estabelecidas pelas políticas de habitação e solo urbano. O enfrentamento deste conflito se constitui hoje em campo fundamental de atuação dos movimentos.

Palavras-chave: 1. Habitação popular 2. Solo urbano 3. Movimentos sociais urbanos 


\begin{abstract}
RODRIGUES, Evaniza Lopes. The Land strategy from Housing popular movements in the collective self-managed housing production. 2013. 233 p. Dissertação (Mestrado) Faculdade de Arquitetura e Urbanismo, Universidade de São Paulo, São Paulo, 2013.

The housing social movements, that defend the collective self-managed agenda, act in Brazil since the 80 's and are protagonists of the recent legal and institutional construction of the urban and housing policies in Brazil. The public housing programs Crédito Solidário (Solidary Credit) and Minha Casa Minha Vida Entidades (My House My Life Entities), outcomes of a trajectory of mobilization and pressure of these movements recognize the performance of cooperatives, social organizations and popular movements as promotional agents of housing enterprises with federal resources.
\end{abstract}

The access to the well located urban land for the popular housing has been in the agenda of movements for urban reform that have developed direct actions, as public occupations and mobilizations, legislative initiatives and institutional actions, as the participation in public policies councils. However, the set of instruments available to the society to regulate the use of the territory had been not effectively implanted yet. Thus, the search for available areas for houses of social interest is even more difficult in the absence of land policies, in a local and national level, added to the abundance of available public and private resources for the civil construction sector as well as the financialization of the housing and city production. Such a task becomes even more arduous for social movements.

Minha Casa Minha Vida enshrines a model of housing production based on a single model of access to the individual property of the house by acquisition, although with considerable subsidies, which becomes immediately a commodity and to this end entails an adjusted normative apparatus. A conflict is configured between the proposal of collective selfmanaged housing policies as formulated by the movements and the conditions established for the urban housing and land policies. Facing this conflict constitutes today the main field of action for the movements.

Key words: 1. Popular housing 2. Urban Land 3. Urban social movements 


\section{LISTA DE FIGURAS}

Figura 1 - Participação de mulheres no mutirão - São Paulo/SP - 2003

Figuras 2, 3, 4 e 5 - Discussão de projeto - Mutirão Tania Maria - Suzano/SP - 2010

Figuras 6 e 7- Discussão a Aprovação de projeto - Mutirão Florestan Fernandes e José Maria Amaral - São Paulo/SP - 2012

Figura 8 - Gestão da obra - Grupo Esperança - Rio de Janeiro/RJ - 2012

Figura 9 - Trabalho em Mutirão - City Jaraguá- São Paulo/SP - 2003

Figura 10 - Mutirão Jardim Celeste - FUNAPS Comunitário - São Paulo/SP - 2001

Figura 11 - Mutirão 26 de Julho - FUNAPS Comunitário - São Paulo/SP - 1992

Figura 12 - Mutirão XV de Novembro - São Paulo-SP - 2001

Figura 13 - Manifestação contra a paralização dos mutirões - São Paulo-SP - 1993

Figura 14 - Mutirão União da Juta - Financiamento CDHU - São Paulo/SP - 1998

Figura 15 - Mutirão Vila Albertina - Financiamento CDHU - São Paulo/SP

Figura 16 - Entrega do projeto de lei do Fundo Nacional de Moradia - Brasília 1991

Figura 17 - Lançamento do Programa Minha Casa Minha Vida - Brasília - 2009

Figura 18 - Mutirão Jd. Santo André - 2000

Figura 19 - Caravana da Moradia à Brasília - 1998

Figura 20 - Mutirão Colinas da Oeste - PCS - São Paulo/SP - 2011

Figura 21 - Vale das Flores - PCS - São Paulo -SP - 2012

Figura 22 - Residencial Maria Firmina - Paço do Lumiar/MA - 2009

Figura 23 - Trabalho em mutirão - PCS Mar Azul - Salvador/BA - 2008

Figuras 24, 25 e 26 - Moradias rurais produzidas pelo PNHR - 2011 e 2012

Figura 27 - Empreendimento Mangabeiras - MCMV-Entidades - Feira de Santana/BA - 2012

Figura 28 - Residencial Lagoa Quente - MCMV - E - Caldas Novas/GO - 2012

Figura 29 - Cartilha Vamos Mudar Nossas Cidades? 
Figuras 30, 31 e 32 - Exemplos de Conjuntos produzidos pelo MCMV - FAR distantes do tecido urbano - 2010 e 2011

Figura 33 - Residencial Meu Orgulho - Manaus/AM (foto parcial) - 2012

Figura 34 - Exemplo de empreendimento do MCMV - FAR inserido na malha urbana - 2011

Figura 35 - Ocupação Jd. S. Francisco -São Paulo-SP - 1993

Figura 36 - Ocupação imóvel público em área central - São Paulo/SP - 1997

Figura 37 - Manifestação em defesa de moradia em área central - São Paulo/SP 2006

Figura 38 - Ocupação em Superintendência do INSS - São Paulo/SP - 2008

Figuras 39, 40, 41 e 42- Visita para aprovação e realização de estudo de terreno para MCMV Entidades - São Paulo/SP - 2009

Figura 43 - Projeto José Maria Amaral e Florestan Fernandes - MCMV-E - São

Paulo/SP - 2010

Figuras 44, 45 e 46 - Implantação, edificação e entorno do empreendimento V.

Patrimonial - São Paulo/SP - 2012

Figura 47, 48 e 49 - Localização Mutirão Barra do Jacaré e Vale das Flores - São Paulo-SP e Parque das Aguas - PCS - Ipatinga/MG

Figura 50 - Área do empreendimento Santa Sofia

Figura 51 - Caravana à Brasília- 2011 - FNRU

Figura 52 - Edifício do INSS da Avenida 9 de Julho - São Paulo/SP - 2001

Figura 53 - Ocupação em imóvel do INSS - São Paulo/SP - 2010

Figura 54 e 55 - Edifício Residencial Conquista - PCS - 48 Uh - Coopernova - MNLM - Porto Alegre/RS - 2010 


\section{LISTA DE TABELAS}

Tabela 1 - Metas e modalidades do programa Minha Casa Minha Vida

Tabela 2 - Metas do programa Minha Casa Minha Vida versus Déficit Habitacional

Tabela 3 - Síntese das regras de financiamento

Tabela 4 - Quantidades de unidades habitacionais contratadas por faixa de renda MCMV 1 e 2 (2009 - 2013)

Tabela 5 - Distribuição de unidades contratadas e meta na Faixa 1, por programa

Tabela 6 - Volume de contratações do PCS e MCMV-E (unidades habitacionais por ano)

Tabela 7 - Distribuição regional dos empreendimentos e das unidades habitacionais

Tabela 8 - Contratos de aquisição de terreno e elaboração de projetos 


\section{LISTA DE GRÁFICOS}

Gráfico 1 - Déficit habitacional versus metas MCMV

Gráfico 2 - MCMV -Percentual de contratação por faixa de renda em relação à meta

Gráfico 3 - Participação de cada programa na faixa 1 (UHs contratadas/programa) 90

Gráfico 4 - Empreendimentos contratados por ano

Gráfico 5 - Localização dos empreendimentos 156

Gráfico 6 - Modalidades de contratação

Gráfico 7 - Situação dos contratos

Gráfico 8 - Regimes de construção 158

Gráfico 9 - Forma de aquisição do terreno 158

Gráfico 10 - Prazo para a aquisição do terreno 165

Gráfico 11 - Como a entidade encontrou o terreno 166

Gráfico 12 - Ocupação no terreno 167

Gráfico 13 - Gastos realizados pela entidade até a contratação 168

Gráfico 14 - Valor pago por metro quadrado de terreno 168

Gráfico 15 - Relação entre valor do terreno e valor do empreendimento (\%) 169

Gráfico 16 - Valor da fração por UH (R\$) 170

Gráfico 17 - Tamanho da fração de terreno por UH $\left(\mathrm{m}^{2}\right)$ 170

Gráfico 18 - Infraestrutura preexistente no entorno do terreno 173

Gráfico 19 - Prazos para o licenciamento 


\section{LISTA DE ABREVIATURAS E SIGLAS}

Aneel - Agência Nacional de Energia Elétrica

APP - Área de Proteção Permanente

BNH - Banco Nacional de Habitação

Caixa - Caixa Econômica Federal

Cbic - Câmara Brasileira da Indústria da Construção Civil

CCFDS - Conselho Curador do Fundo de Desenvolvimento Social

CDHU - Companhia de Desenvolvimento Habitacional e Urbano do Estado de São Paulo

CDRU - Concessão do Direito Real de Uso

CMP - Central de Movimentos Populares

Cohab - Companhia de Habitação

Conam - Confederação Nacional de Associações de Moradores

ConCidades - Conselho Nacional das Cidades

Cuem - Cessão de Uso Especial para Fins de Moradia

FAR - Fundo de Arrendamento Residencial

FDS - Fundo de Desenvolvimento Social

FGTS - Fundo de Garantia do Tempo de Serviço

FNHIS - Fundo Nacional de Habitação de Interesse Social

FNRU - Fórum Nacional de Reforma Urbana

Gidur - Gerência Regional de Desenvolvimento Urbano

GTE - Grupo de Trabalho Estadual da SPU

GTN - Grupo de Trabalho Nacional da SPU

HIC - Coalizão Internacional do Hábitat

HIS - Habitação de Interesse Social

IAPs - Institutos de Aposentadorias e Pensões

INSS - Instituto Nacional de Seguro Social

MCidades - Ministério das Cidades

MCMV - Programa Minha Casa Minha Vida

MCMV-Entidades - Programa Minha Casa Minha Vida Entidades

MNLM - Movimento Nacional de Luta por Moradia 
MST - Movimento dos trabalhadores Rurais Sem Terra

OGU - Orçamento-Geral da União

ONG - Organização Não Governamental

ONU - Organização das Nações Unidas

PAC - Programa de Aceleração do Crescimento

PAR - Programa de Arrendamento Residencial

PCS - Programa Crédito Solidário

PDP - Plano Diretor Participativo

Planhab - Plano Nacional de Habitação

PLHIS - Plano Local de Habitação de Interesse Social

RFFSA - Rede Ferroviária Federal

$\mathrm{RI}$ - Cartório de Registro de Imóveis

SCC - Centro Cooperativo Sueco

Selvip - Secretaria Latino-Americana de Moradia Popular

SNH - Secretaria Nacional de Habitação

SNHIS - Sistema Nacional de Habitação de Interesse Social

SPU - Secretaria do Patrimônio da União

UMM-SP - União dos Movimentos de Moradia de São Paulo

UNMP - União Nacional por Moradia Popular

Zeis - Zona Especial de Interesse Social 


\section{SUMÁRIO}

$\begin{array}{ll}\text { INTRODUÇÃO } & 19\end{array}$

$1 \quad$ A AUTOGESTÃO COMO PROPOSTA 22

$\begin{array}{lll}1.1 & \text { Porque a autogestão } & 25\end{array}$

1.2 A ação autogestionária na habitação 31

$\begin{array}{lll}1.3 & \text { Trajetória da autogestão na habitação } & 37\end{array}$

1.4 Autogestão e direito à cidade 42

1.5 Articulações em nível internacional 45

2 A AUTOGESTÃO HABITACIONAL NO GOVERNO FEDERAL 48

2.1 Política Habitacional no Brasil 49

2.1.1 Minha Casa Minha Vida 54

2.2 Autogestão no governo federal - projetos-piloto e pressão popular 60

2.2.1 Programa Crédito Solidário 65

2.2.2 Sistema Nacional de Habitação de Interesse Social e Programa Produção Social da Moradia $\quad 69$

2.2.3 Minha Casa Minha Vida -Entidades 72

2.3 Características dos programas em parceria com entidades 76

2.3.1 Formas de acesso ao financiamento habitacional 76

$\begin{array}{lll}\text { 2.3.2 } & \text { Acesso a terreno para os programas } & 78\end{array}$

2.3.3 Gestão da produção habitacional $\quad 80$

2.3.4 Luta contra a burocracia estatal 82

2.3.5 O papel da Assessoria técnica 84

2.3.6 A importância do trabalho social 86

2.4 O Lugar da autogestão na política habitacional 87 
3.1 Aspectos históricos do processo de apropriação da terra no Brasil 96

3.2 A lei de terras e o surgimento da propriedade privada, individual e absoluta 99

3.3 A privatização da política fundiária no Brasil 102

$\begin{array}{ll}\text { 3.3.1 A hegemonia da propriedade privada } & 102\end{array}$

3.3.2 Terra urbana na hegemonia do capital financeiro 105

3.4 Instrumentos urbanísticos: As promessas continuam válidas? 108

4. A QUESTÃO DA TERRA NAS POLÍTICAS HABITACIONAIS 115

$\begin{array}{lll}4.1 & \text { Os conjuntos habitacionais } & 119\end{array}$

4.2. Terra para Moradia nos Planos Diretores 122

4.3. Estratégias urbanas e fundiárias no PlanHab 129

4.4. Terra no Minha Casa Minha Vida 133

5 A QUESTÃO DA TERRA NOS PROGRAMAS AUTOGESTIONÁRIOS DE MORADIA $\begin{array}{ll}\text { POPULAR } & 145\end{array}$

5.1 Movimentos Sem-Terra na cidade 146

5.2 A questão da terra nos programas locais de autogestão $\quad 151$

$\begin{array}{lll}\text { 5.3 Terra nos programas federais - PCS e MCMV } & 153\end{array}$

5.3.1 Diagnóstico e considerações sobre os empreendimentos pesquisados $\quad 155$

$\begin{array}{lll}\text { 5.3.2 Doação de terras pelas prefeituras } & 159\end{array}$

$\begin{array}{lll}\text { 5.3.3 O Movimento vai ao Mercado } & 160\end{array}$

$\begin{array}{ll}\text { 5.3.4 Localização e Infraestrutura } & 173\end{array}$

$\begin{array}{lll}\text { 5.3.5 Aprovação e Licenciamento } & 176\end{array}$

$\begin{array}{lll}\text { 5.3.6 Relação com os cartórios } & 180\end{array}$

$\begin{array}{lll}5.4 & \text { Compra antecipada } & 183\end{array}$

$\begin{array}{lll}5.5 & \text { Terras públicas federais } & 192\end{array}$

$\begin{array}{ll}\text { CONCLUSÕES } & 199\end{array}$ 
ANEXOS

ANEXO 1 - Lista dos Empreendimentos pesquisados

ANEXO 2 - Roteiro para entrevista de caracterização do empreendimento

ANEXO 3 - Localização de empreendimentos PCS e MCMV

ANEXO 4 - Roteiro para elaboração do "Laudo de viabilidade técnica de empreendimentos habitacionais de interesse social" - PMCMV-E 


\section{INTRODUÇÃO}

A militância no movimento de moradia nos últimos 24 anos e a constatação de que cada dia somos mais "sem terra" em nossas cidades motivou o tema desta dissertação. 0 acesso à terra urbanizada e bem localizada para a habitação popular tem estado na pauta dos movimentos de reforma urbana desde a sua formação na década de 1980. As ocupações de terra e de imóveis ociosos, a construção de instrumentos urbanísticos e de controle social e sua consolidação em dispositivos legais buscam o cumprimento da função social da cidade e da propriedade.

A pesquisa investigou as formas e processos de obtenção de terrenos para viabilização de projetos para a produção de moradia, através da autogestão, por parte de movimentos populares, no contexto da recente financeirização do componente fundiário e das estratégias de produção habitacional do Programa habitacional Minha Casa Minha Vida. Os programas Crédito Solidário e Minha Casa Minha Vida Entidades, frutos de uma trajetória de mobilização e pressão desses movimentos, reconhecem a atuação de entidades sociais, cooperativas e movimentos populares como agentes promotores de empreendimentos habitacionais, com recursos públicos federais. O marco temporal, de 2004 a 2012, engloba o período de vigência desses programas habitacionais federais em parceria com associações populares e cooperativas.

Para dar voz aos movimentos e entidades, em suas proposições e avaliações das políticas públicas e programas, foi realizado um levantamento de documentos de encontros, manifestos, cartas públicas e ofícios dirigidos ao governo federal, no período de 1994 a 2012. Esse material serviu de linha de condução e de contraponto às posições e iniciativas do governo federal, demonstrando a postura ao mesmo tempo crítica e propositiva por parte das organizações. Foram priorizados os documentos do Fórum Nacional de Reforma Urbana e da União Nacional por Moradia Popular.

Para apoiar essa reflexão, além da análise dos dados quantitativos dos empreendimentos produzidos através dos Programas Minha Casa Minha Vida e Crédito 
Solidário, foi realizada uma pesquisa com 40 empreendimentos contratados ou em via de contratação nesses programas. São empreendimentos de entidades vinculadas aos movimentos nacionais de luta por moradia, distribuídos pelas 5 regiões brasileiras. Essa amostra, que representa $8 \%$ dos empreendimentos contratados, nos ajuda a entender a diversidade de dificuldades encontradas e de alternativas construídas pelo movimentos para enfrentar as exigências e viabilizar empreendimentos.

O primeiro capítulo traz a autogestão na habitação como referência e ponto de partida desta reflexão. Os movimentos populares de luta por moradia, que defendem a proposta autogestionária, atuam no Brasil desde a década de 80 e são protagonistas da recente construção legal e institucional da política urbana e habitacional brasileira. A autogestão, mais do que um modo de construir moradias, é um conceito que envolve a participação e o controle da produção da habitação, uma maneira de construção de vida comunitária e de produção não mercantil da moradia, concebida como direito e não como mercadoria.

O segundo capítulo traz uma memória da reivindicação de programas habitacionais autogestionários em nível federal e das respostas governamentais a essa demanda, culminando com os programas Crédito Solidário e Minha Casa Minha Vida Entidades. Aborda também as principais características desses programas e sua relação com a proposta autogestionária, além de demonstrar a pequena relevância da proposta dentro da estratégia do Programa Minha Casa Minha Vida, bem como as incoerências e contradições existentes entre esses dois modelos.

O terceiro capítulo, parte de um pequeno histórico da propriedade privada individual no Brasil e das formas de sua aquisição e uso, e busca identificar as dificuldades atuais encontradas na construção de uma política fundiária e os limites das opções governamentais adotadas nesse campo, cujas consequências, em princípio, contribuem para um aprofundamento da crise urbana. Nesse capítulo, são abordadas a financeirização da terra e as dificuldades para a implementação de instrumentos que visam fazer cumprir a função social da propriedade. 
O quarto capítulo trata do aspecto fundiário nas políticas habitacionais. Os avanços propostos pelo Estatuto da Cidade, os planos diretores e o Plano Nacional de Habitação servem de referência para a avaliação da forma como o Programa Minha Casa Minha Vida tem tratado o tema e as consequências imediatas de sua atuação.

Assim, a ausência de política fundiária, em nível local e nacional aliada à abundância de recursos públicos e privados disponíveis para o setor da construção civil e a financeirização da produção da moradia e da cidade fazem com que a busca por áreas disponíveis para a produção habitacional de interesse social, particularmente pelas entidades populares, seja cada vez mais difícil.

O quinto capítulo traz uma reflexão sobre as formas de acesso à terra nos projetos autogestionários de habitação. O texto parte da trajetória dos movimentos de moradia e a presença constante do tema fundiário em sua agenda e como os programas locais trataram a questão. O ponto central do capítulo é a discussão sobre o acesso à terra nos programas Crédito Solidário e Minha Casa Minha Vida Entidades, em seus diversos aspectos: propriedade e regularidade fundiária, acesso aos imóveis públicos, relação com o mercado imobiliário, com os órgãos licenciadores e de registro público. O texto também conta a trajetória das propostas do movimento popular sobre o tema, culminando com a elaboração de uma modalidade de aquisição de terrenos, denominada Compra Antecipada. A função social dos imóveis públicos também é discutido nesse texto.

Por fim, verifica-se que o Programa Minha Casa Minha Vida consagra um modelo de produção habitacional calcada em um modelo único de acesso, através da aquisição, ainda que com subsídios expressivos, da propriedade individual da casa, que se torna, imediatamente, produto de mercado, com um aparato normativo adequado a esse objetivo. Configura-se assim um conflito entre a proposta de política habitacional autogestionária formulada no âmbito dos movimentos e as condições estabelecidas pelas políticas de habitação e solo urbano. O enfrentamento deste conflito se constitui hoje em campo fundamental de atuação dos movimentos da reforma urbana. 
1 A AUTOGESTÃO COMO PROPOSTA 
Com a retomada do processo democrático, a partir da década de 1980, os movimentos de moradia, no cenário das lutas sociais no Brasil, marcaram as lutas urbanas, atuando no desenvolvimento de propostas e reivindicações junto ao poder público, em ações diretas de ocupação de imóveis, na resistência a despejos e reintegrações de posse, ou, ainda, como um dos agentes participantes nos novos programas habitacionais.

Paz (1996, p. 37) afirma que

A principal contribuição dos movimentos sociais tem sido no aprofundamento do processo democrático brasileiro, enquanto reconstrução de espaços de organização e participação na vida cotidiana, e de valores éticos e democráticos. Nosso entendimento é de que a consolidação dos movimentos sociais enquanto sujeitos políticos da democratização brasileira traz por consequência, mudanças nas relações que se estabelecem entre os indivíduos, na sociedade em geral e destas com o Estado.

Apesar da repressão aos movimentos populares, durante o período da ditadura, os movimentos de moradores de loteamentos irregulares e o Movimento de Defesa dos Favelados (este de caráter nacional) já atuavam no País desde os meados da década de 1970.

No final dos anos 70 e início dos 80, momento em que o Brasil viveu um processo de expansão das periferias, acompanhado por sérios problemas urbanos, surge uma infinidade de movimentos espontâneos os quais, com apoio da Igreja Católica, de profissionais, intelectuais e entidades comprometidas ou de outros movimentos populares, se articulam nos bairros, nas favelas e em determinadas regiões das cidades lutando por melhores condições de vida.

São, na expressão consagrada de Sader (1988), os novos personagens, que entram nas cenas política e social. Na década de 1980, extensas e numerosas ocupações de terra, nas periferias das metrópoles, impulsionam as organizações que, com o decorrer do tempo, estabelecem articulação entre as reivindicações pontuais e específicas das organizações locais e as agendas mais amplas ligadas ao direito à cidade.

Característica de parte desses novos movimentos é seu caráter propositivo. Paz (1996, p. 97) destaca o movimento de passagem de "seu caráter reivindicativo pelo atendimento das necessidades imediatas, para a proposição de políticas públicas e de seu reconhecimento institucional, enquanto sujeito político que intervém e negocia com outras 
forças sociais". Nesse marco, inserem-se a proposta dos mutirões autogestionários, a elaboração de iniciativas populares de lei e a criação de instâncias institucionais de participação.

Essas organizações, que proliferaram em nível local, também vão construindo articulações e propostas de caráter nacional. Em nível nacional, a necessidade e o desejo de articular-se surgem à medida que se aprofunda a crítica à política habitacional oficial do governo federal, marcada por critérios financeiros excludentes e, por consequência, pela exclusão das famílias mais pobres e dificuldade de acesso aos recursos, como veremos adiante. O resultado é a construção de entidades nacionais com plataformas propositivas no campo da política urbana e de habitação.

Desse processo, nascem a Confederação Nacional de Associações de Moradores (Conam), em 1984; o Movimento Nacional de Luta por Moradia (MNLM), formado em 1990; a União Nacional por Moradia Popular (UNMP), em 1993; e a Central de Movimentos Populares, em 1997. Esses movimentos atuam a partir de diversas expressões da questão da moradia, como as favelas, os cortiços, loteamentos irregulares ou ilegais, de mutuários e dos sem-teto que demandam a provisão de moradias, sempre pressionando o poder público, em níveis federal, municipal e estadual, e formulando propostas alternativas para a política habitacional.

Os movimentos também construíram articulações permanentes com outros atores sociais, principalmente o Fórum Nacional de Reforma Urbana (FNRU), integrado por movimentos populares, Organizações Não Governamentais (ONGs) e organizações sindicais

Gohm (1991, p. 11) explicita essas diferentes dimensões dos movimentos:

\footnotetext{
${ }^{1}$ A coordenação do FNRU é composta por representantes das seguintes entidades: Confederação Nacional de Associações de Moradores (Conam); Movimento Nacional de Luta pela Moradia (MNLM); União Nacional por Moradia Popular (UNMP); Central de Movimentos Populares (CMP); Federação Nacional das Associações de Empregados da Caixa Econômica (Fenae); Federação Interestadual dos Sindicatos de Engenharia (Fisenge); Instituto de Estudos, Formação e Assessoria em Políticas Sociais (Pólis); Federação Nacional dos Arquitetos e Urbanistas (FNA); Instituto Brasileiro de Administração Municipal (Ibam); Instituto Brasileiro de Análises Sociais e Econômicas (Ibase); ANTP - Associação Nacional de Transportes Públicos (ANTP); Centro pelo Direito à Moradia contra Despejos (Cohre) Américas; Associação dos Geógrafos Brasileiros (AGB); Federação Nacional dos Estudantes de Arquitetura e Urbanismo do Brasil (Fenea); Centro de Assessoria à Autogestão Popular (Caap); Associação Brasileira de Ensino de Arquitetura e Urbanismo (Abea); Bento Rubião - Centro de Defesa dos Direitos Humanos; Rede Observatório das Metrópoles; ActionAid Brasil; Conselho Federal de Serviço Social (Cfess); Habitat para a Humanidade; Fórum Nordeste de Reforma Urbana (FneRU); Fórum da Amazônia Oriental (Faor)/GT Urbano; Fórum Sul de Reforma Urbana; e Fórum Urbano da Amazônia Ocidental (Faoc).
} 
Vários movimentos sociais passaram a agendar em suas atividades cotidianas, reuniões para discutir e/ou elaborar subsídios para projetos de lei (...). A sociedade civil organizada passa a buscar a inscrever em lei seus direitos e deveres. Ou seja, passa a querer interferir diretamente na sociedade política e no funcionamento do Estado.

\subsection{Porque a autogestão}

A proposta autogestionária propõe a melhoria das capacidades econômica, social e política dos setores populares. Além disso, a ação autogestionária empodera a comunidade, qualificando sua interlocução e a prepara para os enfrentamentos com o poder público.

A definição de autogestão na área habitacional refere-se a ações em que a produção de moradias, ou a urbanização de uma área, ocorra com o controle dos recursos públicos e da obra pelos movimentos populares, pelas associações e cooperativas. Neste capítulo, demonstra-se tanto a dimensão da forma de implementação de programas habitacionais quanto as abrangências política e social da prática autogestionária.

Essa forma de atuação consiste não apenas na construção de moradias ou na urbanização, mas tem como pano de fundo o questionamento das estruturas sociais e econômicas, das injustiças sociais, como parte integrante do sistema econômico e da preponderância dada ao setor privado capitalista na produção do espaço construído e da cidade, como se verá neste capítulo.

A União Nacional por Moradia Popular (UNMP), durante o Seminário Nacional de Autogestão, demonstra essa convergência de objetivos e defende “(...) a autogestão como um projeto político transformador, e proposta de gestão de políticas públicas, assim como uma via fundamental e solidária para a melhoria da qualidade de vida e conquista de uma moradia com baixo custo" 2 .

Jeifetz $^{3}$ caracteriza a autogestão como "uma noção de construção de poder popular (...) de uma cultura de transformação, de desenvolvimento organizacional a partir da

\footnotetext{
2 UNMP. Carta de Pernambuco, 2004.

3 "Ejes autogestionarios en la producción social del habitat." In ORTIZ, E; ZARATE, M.L. (compiladores) Vivitos y coleando. 40 años trabajando por el hábitat popular en América Latina.HIC-AL, Universidad Autónoma Metropolitana, México, 2002, p. 79.
} 
perspectiva de ser parte dos processos unitários do campo popular, para transformar a atual realidade socioeconômica e cultural e construir uma nova realidade".

Propõe, ainda, que o conceito da autogestão não envolve uma construção que se opõe ao estado, ou que atua em paralelo, mas uma ação voltada para a transformação do estado, para que não seja mais uma estrutura a serviço do capital e da dominação de classes. A autogestão também tem sido um espaço de resistência contra as políticas que pregam a diminuição do estado e sua retirada das políticas públicas do hábitat em favor do mercado.

A autogestão insere-se em um conjunto de práticas e propostas de movimentos populares de toda a América Latina, denominada Produção Social do Hábitat (PSH). Esse conceito

trata de complexos processos de auto-organização, construídos a partir de movimentos coletivos e interações dos moradores urbanos gerando projetos e ações voltadas para assegurar os seus direitos à cidade e habitação. $O$ eixo articulador desses processos é a luta organizada por terra, habitação e serviços básicos. (ORTIZ e ZARATE, 2004, p.16) ${ }^{4}$.

Essas práticas podem ser observadas em ocupações organizadas de terra urbana; em ações de melhorias, em favelas e loteamentos, feitas coletivamente; nas lutas por reconhecimento e regularização fundiária; na luta por equipamentos e serviços públicos, muitos desses também autogeridos. Essas práticas assumem características distintas, de acordo com a realidade local, mas carregam as marcas de uma visão altermundista, que se articula em distintas redes locais, nacionais e internacionais.

Enrique Ortiz apresenta essas experiências e práticas como forma

de retirar o hábitat e a habitação da conceituação que os reduzem a meros objetos mercadoria, para tentar recuperar a sua função social, cultural e humana, e esclarecer as muitas interações que os potencializam como fatores de desenvolvimento e organização social, ordenamento territorial, uso do solo, preservação ambiental e fortalecimento da economia social e solidária. A PSH é parte desta perspectiva transformadora e tenta articular as muitas experiências realizadas em vários campos, e que se recusam a aceitar um mundo condicionado e regido apenas pela busca de lucro $^{5}$.

\footnotetext{
${ }^{4}$ Tradução da autora.

${ }^{5}$ Producción social de vivienda y hábitat:bases conceptuales para una política pública in El camino posible producción social del habitat en América Latina. Centro Cooperativo Sueco, San José, 2011, p. 14, Tradução da autora.
} 
Apesar de ocorrer no marco do capitalismo, a produção social do hábitat concorre com elementos que não se inscrevem nessa ordem, como a produção coletiva, sem lucro, de moradias e territórios; a apropriação coletiva dos ganhos obtidos; a inclusão social como eixo fundamental; a transformação daquilo que o sistema considera como mercadoria em bem comum; assim como a negação da privatização dos bens sociais. Para Arantes (2002, p. 219), "o mutirão autogerido é um lugar diferenciado dentro da produção capitalista do espaço. Este pequeno e minoritário momento na construção da cidade é um vislumbre do que poderia ser (poderá?) ser uma nova forma de produção".

Ao propor uma forma de produção estranha à produção capitalista, essas práticas incluem-se no processo de construção de uma nova ordem, dentro do que tem sido chamado de economia solidária. Como ensina Singer (2002), a economia solidária busca construir novos modelos de produção, comercialização e distribuição de riquezas, que se opõem ao modelo capitalista de acumulação e propõe a construção de novas relações sociais e econômicas. A economia solidária privilegia as formas associativistas e cooperativistas de organização, com a participação de todos em todo o processo, rompendo a alienação do trabalho e combatendo as desigualdades sociais.

Nessa perspectiva, assim como as demais práticas de economia solidária, a autogestão pode ser vista tanto como uma alternativa dentro do capitalismo, como parte da construção alternativa ao capitalismo.

A autogestão na área de habitação é bandeira contida na plataforma de organizações que denunciam não apenas a falta de apoio a esse modelo, mas a quase exclusividade conferida à produção privada de habitação social financiada com recursos públicos, o que Bonduki (1992, p. 32) qualifica como "transferência de recursos públicos para maximizar lucros privados". Nesse sentido, mais do que política social, habitação é vista como negócio privado e rentável, de interesse de alguns grupos econômicos. Na cartilha da União dos Movimentos de Moradia de São Paulo (UMM-SP), consta que:

Não por acaso, com raras exceções, o poder público pouco tem apoiado essas iniciativas por autogestão, e muito menos financiado a autogestão nos seus programas habitacionais, privilegiando assim empresas privadas. Uma mistura de preconceito com arbitrariedade para atingir seus interesses políticos e/ou 
econômicos. Isso tem feito com que os movimentos populares estejam sempre obrigados a "provar" sua capacidade e integridade moral exacerbada para conseguir alcançar os recursos públicos para a produção de sua moradia ${ }^{6}$.

De modo geral, a autogestão na área da habitação tem sido reivindicada e implementada por movimentos populares do campo da esquerda e que associam a luta por moradia a outras reivindicações urbanas, sociais e econômicas. O Fórum Nacional de Reforma Urbana (FNRU) tem a autogestão e a produção social do hábitat como um de seus eixos de atuação.

A proposta autogestionária também não se limita à proposição de programas que atendam às suas demandas específicas, mas incide na construção de políticas públicas no campo do desenvolvimento urbano e da habitação. Segundo Paz (1996, p. 107),

As experiências de mutirão, as influências do sistema uruguaio e o programa Funacom ${ }^{7}$ apontaram para as lideranças e assessorias da UMM-SP a matriz do que viria a ser o Projeto de Lei de Iniciativa Popular do Fundo Nacional de Moradia Popular.

Esse processo, que se estende de 1990 até 2005, quando finalmente o Sistema Nacional de Habitação de Interesse Social é aprovado, é exemplo de como se estende a proposta de políticas habitacionais e urbanas com essa matriz nos níveis local e nacional.

Outra dimensão explorada neste estudo é a incidência desses processos na vida comunitária. A formação da vida comunitária e a busca por qualidade de vida são características que ultrapassam a construção da moradia. O processo qualifica a forma de inserção social daqueles que dela participam, influencia a comunidade do entorno e tende a marcar a forma de organização da comunidade e a maneira como é reconhecida externamente. Ortiz (2011, p. 15) destaca o potencial dessas práticas como

geradora de tecido social, de manifestações de uma nova cultura na que predominam a solidariedade, a ajuda mútua, a gratuidade e as condições capazes de gerar uma convivência mais viva, lúdica, harmônica e criativa ${ }^{8}$.

Há diversas experiências que demonstram a continuidade do modelo organizativo apreendido durante a obra, como a criação de centros comunitários, creches, trabalhos com

\footnotetext{
${ }^{6}$ UMM-SP. Cartilha de formação de lideranças. São Paulo, 2010.

${ }^{7}$ Funaps Comunitário, programa autogestionário da Prefeitura do Município de São Paulo (1989-1992).

8 Tradução da autora.
} 
crianças e adolescentes, organizações religiosas, esportivas, que carregam a "marca" da autogestão, ainda que de forma híbrida com outros modelos de organização.

Ainda é preciso destacar o papel da autogestão no desenvolvimento da consciência crítica individual e coletiva nas comunidades. Para o processo autogestionário acontecer, é necessário desenvolver capacidades individuais, sensibilização e adesão de cada participante à proposta. Isso demanda intenso trabalho de educação popular, para enfrentar a cultura do imobilismo e do individualismo.

A formação do grupo para a ação coletiva vai trabalhar com a valorização de conceitos, como participação, ajuda mútua, saber popular, solidariedade e utopia, como motivadores da ação. Mais recentemente, se opõe à noção de acesso a direitos como simplesmente acesso ao mercado, bandeira neoliberal que preconiza que, se o trabalhador tiver renda e o mercado imobiliário fornecer o "produto" moradia em escala, não é necessária a ação direta do Estado. Os movimentos populares defendem as políticas públicas e se opõem a essa visão de acesso a direitos por meio apenas da ampliação do consumo, seja de moradia, saúde ou educação privada.

A expressiva participação de mulheres, nas associações e cooperativas, tanto em sua base como, mais recentemente, na direção e responsabilidades de gestão, também é marca encontrada em diversos processos autogestionários. Na esfera privada, a participação em atividades comunitárias tem questionado o papel tradicional da mulher na família, inclusive na luta contra a violencia doméstica. Na esfera pública, é o reconhecimento e a porta para a participação política, a melhor inserção social de mulheres. 
Figura 1 - Participação de mulheres no mutirão - São Paulo-SP - 2003

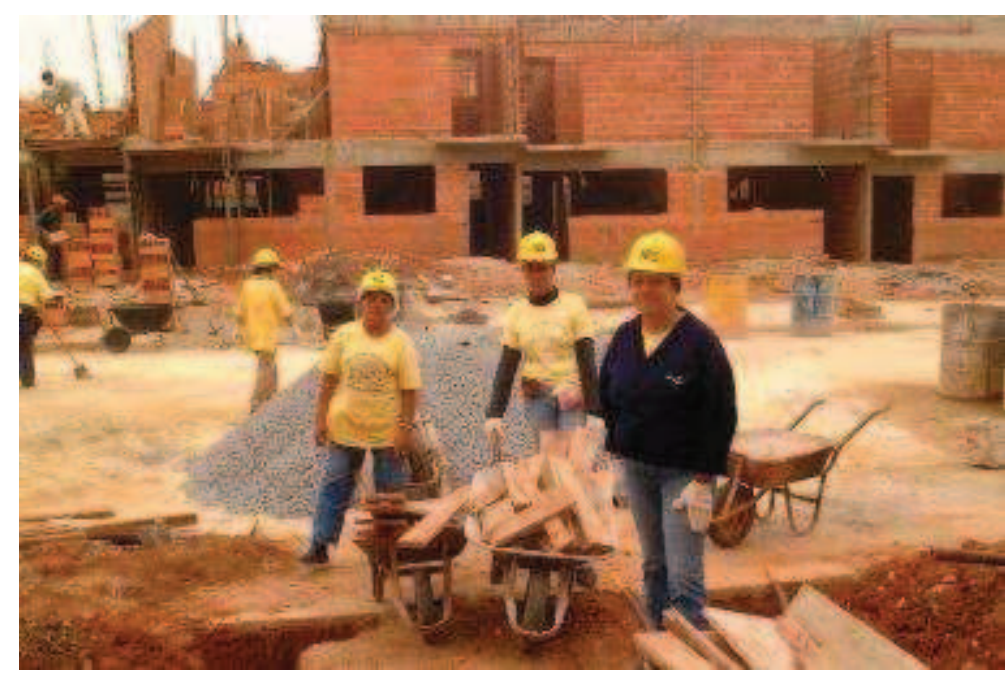

Fonte: Acervo UNMP

Outro elemento é a forma de organização que se busca construir, baseada em relações horizontais de poder. Desde a tomada de decisão sobre como construir um processo autogestionário até a definição de cada etapa desse processo e da forma de enfrentamento das situações adversas, a organização de forma participativa é um requisito fundamental. Para isso, é necessário romper com uma cultura autoritária e elitista, presente, inclusive, nas organizações populares.

Trata-se de um exercício cidadão de construir novas formas de relações sociais e de poder, inicialmente internas ao grupo, mas que vão influenciar na própria visão de mundo. Além das barreiras internas impostas a essa visão, é interessante observar que, de modo geral, as políticas públicas também incentivam uma forma autoritária de gestão e relação com as entidades da sociedade. Formas coletivas de gestão não são bem-vistas e, em alguns casos, proibidas por órgãos públicos ${ }^{9}$.

A proposta de conselhos que definam diretrizes da política habitacional e de desenvolvimento urbano e a destinação dos recursos é defendida em todos os níveis. Experiências desenvolvidas em nível municipal têm ratificado esse instrumento, mas já

\footnotetext{
${ }^{9}$ Por exemplo, para inscrever no Cadastro Nacional de Pessoas Jurídicas, um dos primeiros atos formais de uma entidade, a Receita Federal exige uma única pessoa responsável, geralmente chamada de presidente ou coordenador-geral.
} 
existem críticas sobre distorções em sua utilização. Ressalva-se que somente a existência do conselho não é suficiente, em si, para garantir democracia e participação, exigindo-se que expresse a mobilização e a organização existentes, sem invalidar, nem substituir, a pressão legítima dos grupos.

\subsection{A ação autogestionária na habitação}

De modo geral, são qualificados como autogestionários os processos em que a própria comunidade gerencia a produção da solução relacionada à sua habitação. Fala-se aqui de experiências que não são totalmente autônomas, mas que se inserem, de alguma forma, dentro da política pública de habitação e contam com financiamento e/ou subsídio estatal. Nessa proposta, a comunidade tem sob seu controle todas as etapas para produzir a solução, desde a definição do terreno, projeto, da assessoria técnica que os acompanhará, forma de construção, compra de materiais, contratação de mão de obra, organização do mutirão, prestação de contas e organização da vida comunitária.

Como se trata de empreendimentos dentro de determinada política e de um programa estatal que pode ou não ser desenhado especificamente para esse modelo, em geral, há limites predefinidos por essa política, que podem ser de caráter financeiro, traduzidos pelo teto do valor a ser financiado ou subsidiado, de localização, regularidade fundiária e parâmetros arquitetônicos e urbanísticos. A comunidade terá poder de decisão dentro desses limites e, não raro, existe um tensionamento para a sua superação.

A diferença significativa dos processos autogestionários, se comparados com a produção pública tradicional, é que, para esta o desenvolvimento do empreendimento independe daqueles que lá habitarão. Todas as etapas do processo (localização, projeto, forma de construção e ocupação) são definidas pelo ente público, ou agente promotor construtora ou incorporadora. Ou seja, primeiro vem a casa e depois o seu morador. 
Nos processos autogestionários, na contramão desse conceito, primeiro se forma o grupo de famílias que participará do processo e, a partir dele, se constrói uma proposta de produção habitacional. E esse modo de agir faz toda a diferença.

A escolha da área onde o empreendimento será construído, tema a ser desenvolvido com mais profundidade neste trabalho, no Capítulo 5, pode ser viabilizada com ações diretas de ocupação, pressão para que ocorra a desapropriação, ou regularização, pelo poder público, ou até ser negociada no mercado. De qualquer modo, é o grupo organizado que vai decidir se edificará ou não naquela localidade.

A escolha da equipe de assessoramento técnico é outra característica fundamental. 0 grupo escolherá a assessoria com a qual trabalhará, com foco em uma equipe que tenha comprometimento político e técnico com a proposta do movimento. Os grupos não aceitam assessorias impostas, por exemplo, pelo poder público, justamente por se tratar de uma relação muito além da contratual, mas de convergência de propostas. As assessorias trarão para o grupo o saber técnico, a capacidade de viabilizar o empreendimento, mas, sobretudo, a disposição de compartilhar saber e aprendizado coletivo. Bonduki (1992, p. 163) afirma que "sem assessoria técnica, as organizações populares perdem parte significativa de sua força de proposição, gestão e controle nas políticas públicas".

A fase de elaboração do projeto do novo conjunto habitacional das moradias é um dos espaços privilegiados de participação. Diversas metodologias de elaboração e discussão de projetos têm sido utilizadas, com diferentes graus de influência das famílias, mesmo com os limites já descritos acima. O fundamental é que a decisão sobre o projeto a ser edificado pertence às pessoas que vão nele morar. Isso tem proporcionado maior diversidade, tanto na tipologia das unidades, quanto na própria implantação do conjunto. As unidades geralmente são maiores do que o padrão utilizado na produção convencional e grande parte dos grupos projeta e constrói espaços de uso comum e equipamentos comunitários, a serem geridos coletivamente por meio da continuidade da organização, após finalizada a obra. 
Figuras 2, 3, 4 e 5 - Discussão de projeto - Mutirão Tania Maria - Suzano-SP - 2011
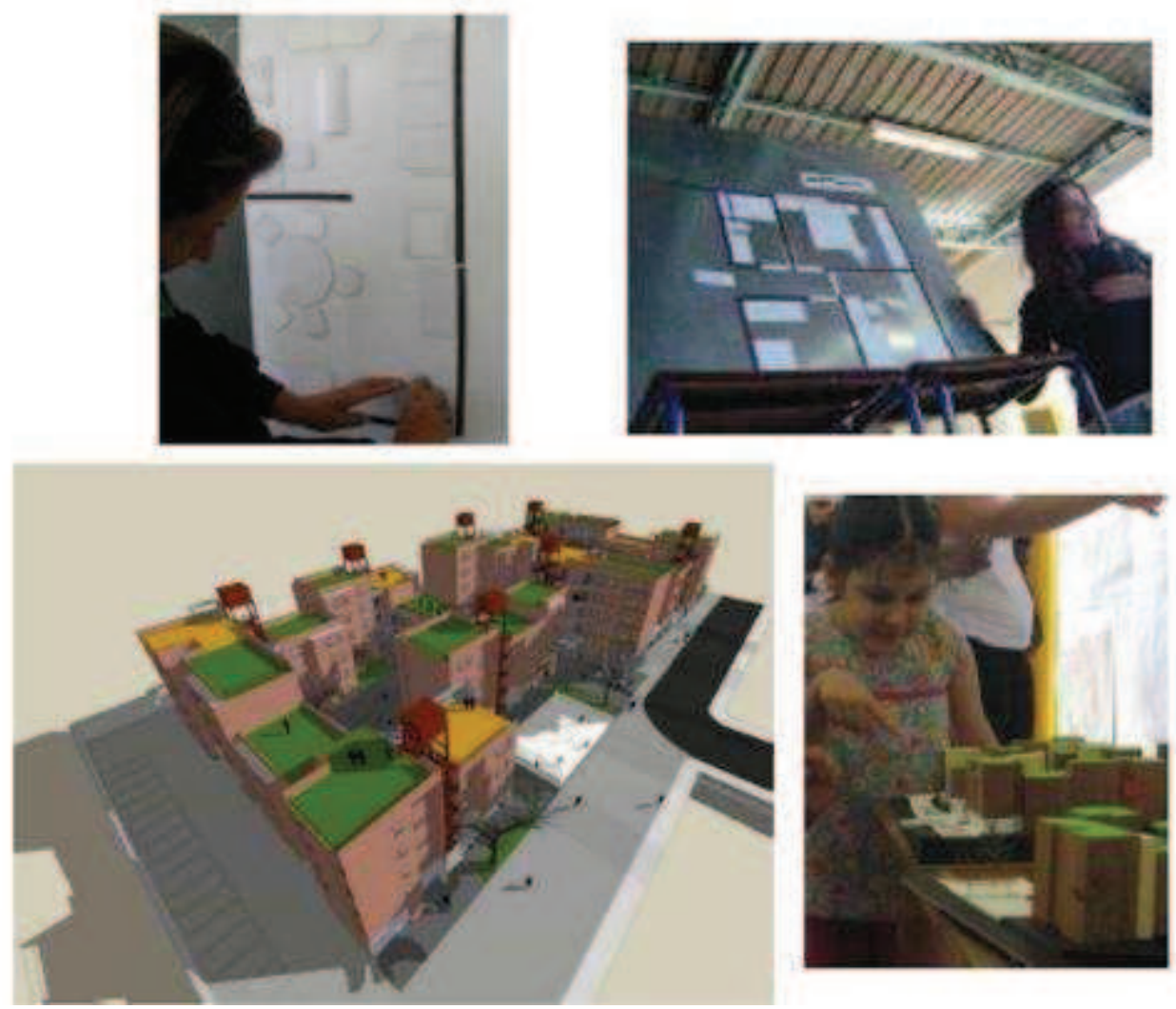

Fonte Usina CTAH

Figuras 6 e 7 - Discussão a Aprovação de projeto em assembleia - Mutirões Florestan Fernandes e José Maria Amaral - São Paulo-SP- 2010
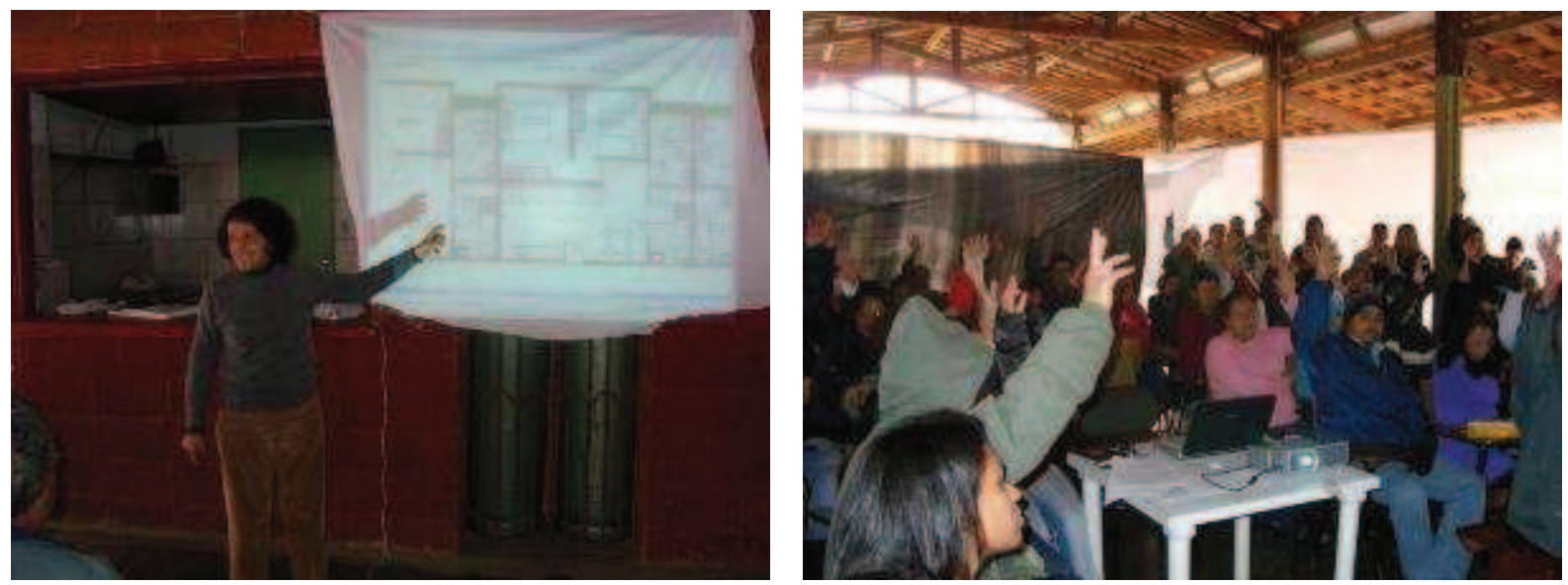

Fonte: A autora

A definição da forma de gestão da obra é outro ponto a ser destacado. Os processos mais bem-sucedidos têm sido aqueles que definem a distribuição de tarefas e responsabilidades dentro do grupo e criam mecanismos de decisão e avaliação permanentes. O maior grau de descentralização da gestão aponta para processos mais 
democráticos e de corresponsabilidade dos participantes. Há, no entanto, grupos que se comportam como pequenas empresas, reproduzindo a hierarquia de poder e centralização das formas tradicionais de organização. Perde-se, assim, a oportunidade de promover uma construção alternativa não apenas de gestão, mas de traduzir uma visão com princípios coletivos a ser implementada na vida daqueles que participam.

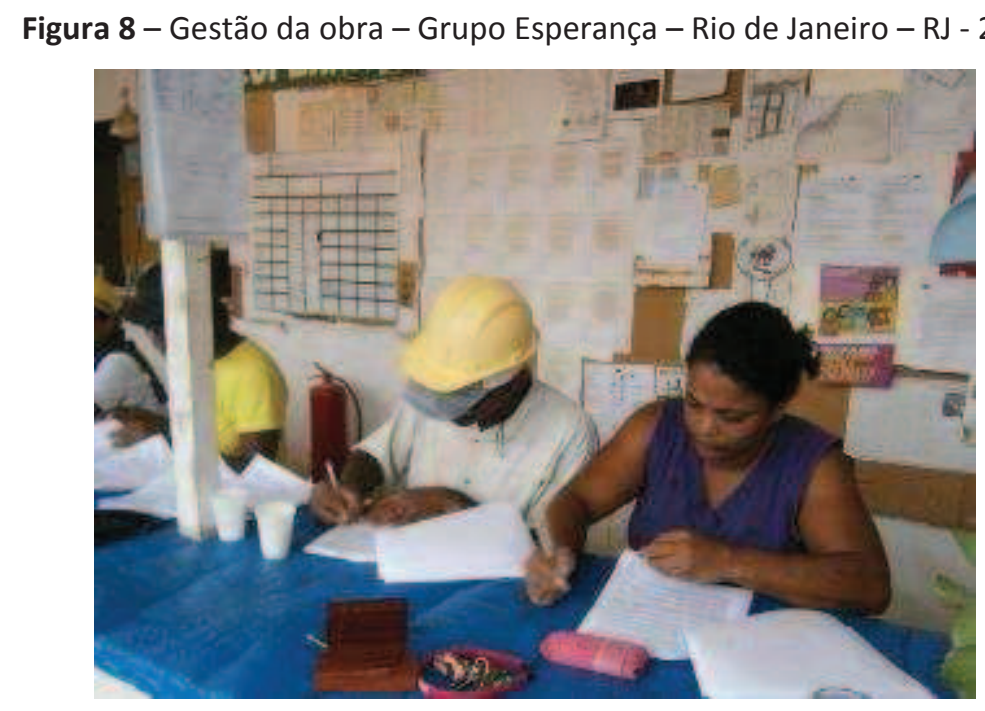

Fonte: Fundação Bento Rubião

Em processos autogestionários, as compras e a contratação de trabalhadores ou serviços, são feitas por representantes das famílias, eleitos para essa finalidade, com o apoio e a orientação da equipe de assessoria técnica. Nesse processo, pessoas que não têm necessariamente formação ou atuação profissional na área da construção vão adquirindo os conhecimentos necessários para exercer tal tarefa. É um resultado visível nos grupos, a qualificação das pessoas na leitura técnica, nas negociações com fornecedores, no controle financeiro, desmistificando o "não saber", por um lado, e socializando capacidades, por outro.

Um ponto sempre polêmico, nos processos autogestionários, é o trabalho em mutirão. Nas primeiras experiências, havia poucos recursos para a contratação de mão de obra especializada e todas as famílias tinham que se comprometer com maior quantidade de horas de trabalho do que é adotada, hoje, nos processos em andamento. Arantes (2002) defende a inclusão do trabalho mutirante nos processos, como forma de democratizar as 
relações e permitir a participação de todos, independentemente de profissão ou educação formal, valorizando o fazer.

O momento da obra restitui novos valores: aqueles ligados ao trabalho manual, ao corpo, à solidariedade, à invenção. A autogestão não pode ser apenas oral e escrita, pois a expressão privilegiada da organização popular ainda é o trabalho manual. Nele, manifesta-se uma forma de colaboração diferente daquela que ocorre na administração da obra, subvertendo inclusive a posição privilegiada dos que discursam melhor nas assembleias, controlam as contas e exercem um domínio sobre o grupo (p. 196).

Figura 9 - Trabalho em mutirão - City Jaraguá- São Paulo-SP - 2003

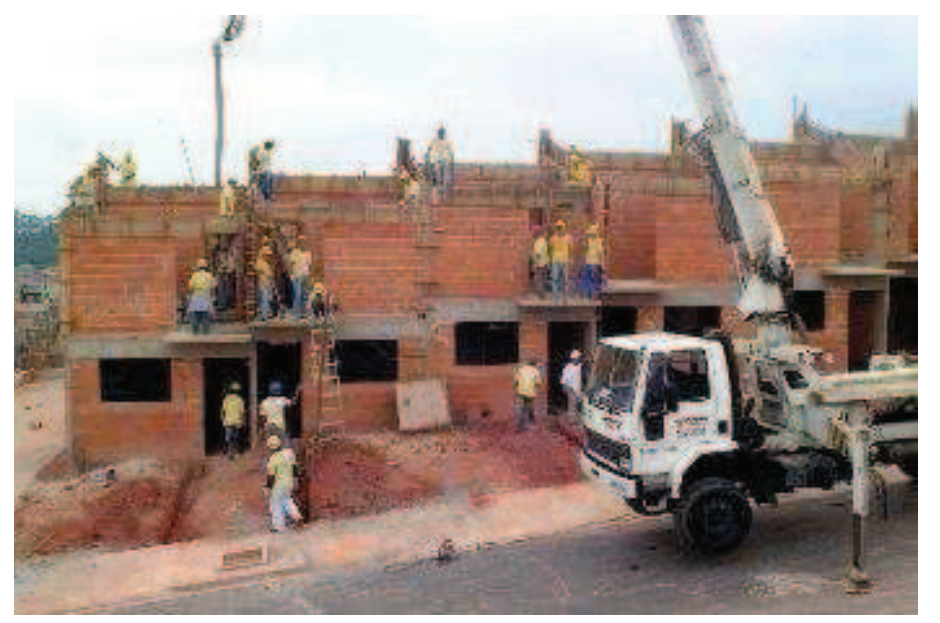

Fonte: Acervo UNMP

Nesses processos, busca-se evitar a reprodução das formas tradicionais do trabalho, comuns na economia capitalista, criando mecanismos de divisão de tarefas e de poder, mas que preservam seu caráter coletivista. Bonduki (1992, p.160) alerta para essa questão e a necessidade de que a opção pelo mutirão seja "mais do que um meio de baratear o custo final da casa, (mas um) instrumento de organização e gestão popular". De qualquer modo, a decisão sobre a existência ou não de trabalho mutirante pertence ao grupo de famílias, a partir da discussão da proposta política do grupo, dos projetos e dos recursos disponíveis.

A definição das regras do jogo em cada um dos grupos que implementa a autogestão dá-se por meio da elaboração e aprovação em assembleia do Regimento de Obra, hoje também já chamado de Regimento de Obra e Participação. No documento, o coletivo define como se dará a participação de cada indivíduo ou família, a quantidade de horas de trabalho, no caso do mutirão, da divisão de tarefas e poder, da composição das comissões de trabalho dentro e fora do canteiro, dos comportamentos aceitos ou não pelo grupo e das penalidades 
para as possíveis infrações. Como todo o processo se dá na base da adesão de cada família, a busca de consensos permeia toda a discussão.

As lideranças do movimento, a assessoria técnica e as experiências anteriores influenciam nessa decisão, que pode variar muito de grupo para grupo, mas o importante é que as regras sejam claras e de conhecimento de todos. Arantes (2002, p. 193) destaca que, ao deixar as regras explícitas, sem privilégios ou discriminações, essa prática combate o clientelismo e o favor, tão presentes nas relações políticas de toda ordem.

Ainda é preciso destacar que a autogestão não visa a obtenção de lucro. Dessa maneira, todos os recursos disponibilizados destinam-se à produção da moradia. $\mathrm{Na}$ produção tradicional capitalista, até $35 \%$ do orçamento é direcionado para Bônus e Despesas Indiretas (BDI) das empresas construtoras. Nos primeiros programas, não havia nenhum recurso reservado a essa rubrica. Atualmente, admite-se a destinação de um percentual para as despesas indiretas que envolvem, entre outras, o fortalecimento institucional da entidade para gerenciar o empreendimento. A ausência do objetivo de lucro garante mais recursos para a construção, melhorando a qualidade do produto e ratificando um modelo alternativo de produção.

Os movimentos não reivindicam que toda a produção da política pública de habitação seja construída com autogestão. No entanto, reivindicam políticas que apoiem a formação e a multiplicação de grupos com capacidade de gestão e proposta política nessa direção. "Muitas experiências não passaram de projetos-piloto, que, apesar de bem avaliados pelos governos, não se converteram em programas estáveis nem foram replicados" 10 .

No Capítulo 2, verifica-se que, mesmo em programas criados para atender entidades sociais, o regime de construção preferencial é a empreitada global, "terceirizando" a produção e tirando da associação o controle da gestão. A questão da escala também é um debate constante, tanto da possibilidade de se ter um grande número de organizações mobilizadas para essa finalidade quanto do tamanho dos empreendimentos a serem construídos, tanto em mutirão quanto de forma autogestionária.

\footnotetext{
10 União Nacional por Moradia Popular: Um pouco de nossa história de luta pela transformação da sociedade. In: Organización y lucha de la Secretaria Latino Americana de la Vivienda Popular. Caracas, p. 4. No prelo.
} 
Como se verá adiante, a existência de programas públicos permanentes estimula a criação de novos grupos e de conjuntos empreendidos, mas não é garantia da prática autogestionária. É inegável, porém, que já há quantidade considerável de moradias produzidas pelos movimentos e experiência acumulada. Para a UNMP,

Hoje, são milhares de famílias que vivem em bairros construídos de forma coletiva,
a partir da autogestão com recursos públicos. Ainda nos deparamos com o
despreparo e preconceito contra as formas autogestionárias de produção
habitacional, como se não fosse o povo o maior construtor de nossas cidades ${ }^{11}$.

\subsection{Trajetória da autogestão na habitação}

A proposta autogestionária, desde o final da década de 1980, torna-se parte fundamental da agenda de lutas dos principais movimentos de moradia no Brasil. Inspirada no modelo uruguaio ${ }^{12}$, a proposta serve de base para a construção de conceitos da relação estado-sociedade, até hoje defendidos pelos movimentos.

As primeiras experiências realizadas em São Paulo, ainda na década de 1980, são fruto da mobilização de comunidades, técnicos, com apoio da Igreja Católica e quase sem nenhum apoio governamental e à margem de qualquer política pública ${ }^{13}$. As grandes ocupações coletivas de terras urbanas, que também ocorrem nesse momento, ao mesmo tempo em que denunciam a falta de políticas governamentais, mobilizam e abrem espaço, no território e no imaginário político, para a construção de uma proposta alternativa de moradia.

O programa de Mutirões da Prefeitura de São Paulo, também chamado de Funaps Comunitário, realizado durante a gestão da prefeita Luiza Erundina (1989 - 1992), foi um

\footnotetext{
${ }^{11}$ Idem, ibidem, p.3.

12 Desde o final da década de 1980, os movimentos de moradia, inicialmente do Rio Grande do Sul e de São Paulo e depois de diversos estados, mantiveram inúmeros intercâmbios com a Federación Uruguaya de Cooperativas de Ayuda Mutua (FUCVAM), que desenvolve o modelo autogestionário desde o final da década de 1960.

${ }^{13}$ BONDUKI, N. (1992) descreve essas iniciativas pioneiras e sua importância para que a autogestão entrasse no imaginário e no repertório dos movimentos populares e nas políticas de habitação.
} 
marco nesse processo. Pela primeira vez, um programa público foi feito exclusivamente com esse caráter, financiando 12.351 unidades habitacionais, em 93 convênios.

Figura 10 - Mutirão Jardim Celeste - FUNAPS Comunitário - São Paulo-SP - 2001

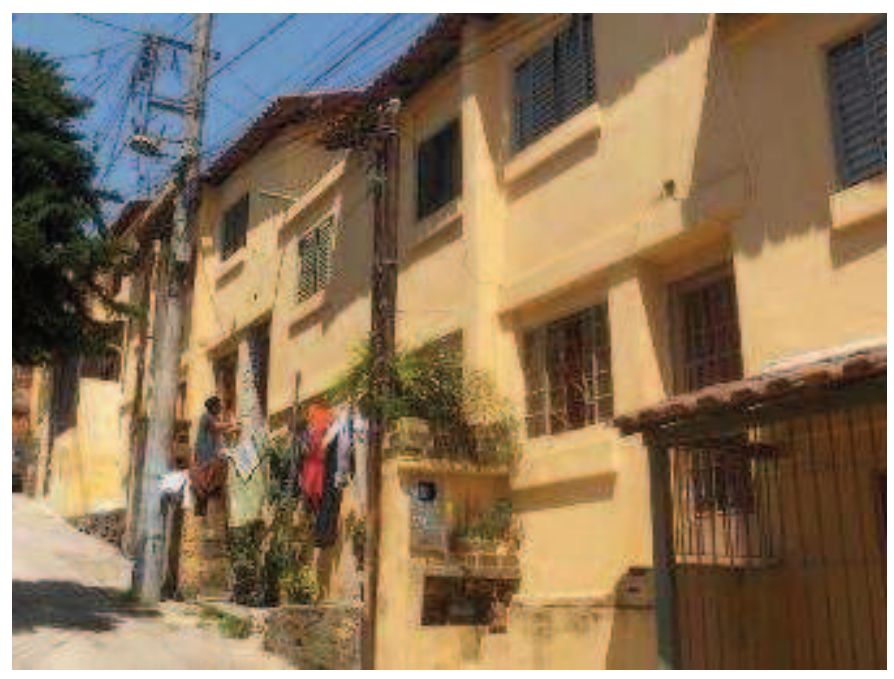

Fonte: Arquivo UMM-SP

Figura 11 - Mutirão 26 de Julho - FUNAPS Comunitário - São Paulo-SP - 1992

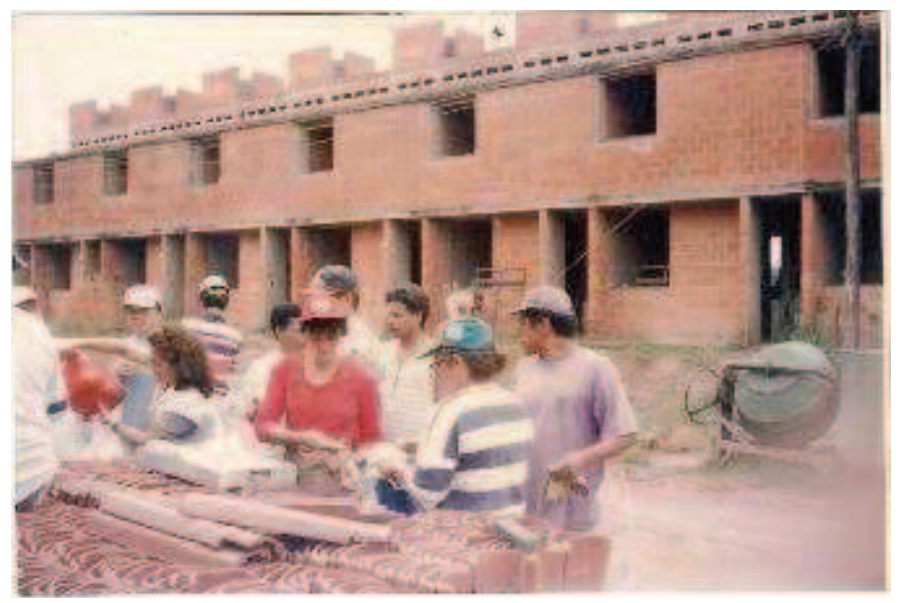

Fonte: Usina CTAH

Realizado exclusivamente com recursos próprios do município, o programa inovou ao repassá-los diretamente às entidades que, junto com uma assessoria técnica escolhida e contratada por elas, eram responsáveis pela elaboração dos projetos, compra dos materiais, execução das obras, feitas parte em mutirão e parte com mão de obra contratada e prestação de contas. Os terrenos eram de propriedade da prefeitura ou da empresa de habitação do município Companhia Metropolitana de Habitação (Cohab-SP), ou ainda adquiridos pelas próprias associações. 
Figura 12 - Mutirão XV de Novembro - São Paulo-SP - 2001

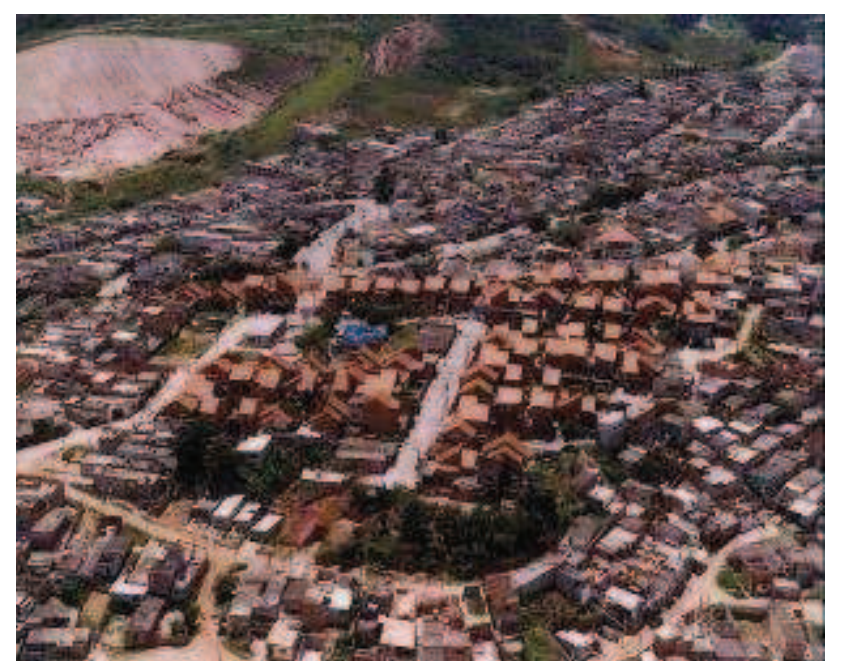

Fonte: COHAB-SP

Além de obterem escala significativa, os resultados demonstraram ganhos na qualidade de projeto e obra e economia de recursos. Também em outras prefeituras, como Ipatinga/MG, Porto Alegre/RS, Belo Horizonte/MG e Diadema/SP e no Distrito Federal e no estado do Rio Grande do Sul, dentre outros, foram criados programas ou linhas de financiamento que apoiaram processos autogestionários. Moreira $(2009$, p. 69) relata que

\footnotetext{
em meio ao contexto de amadurecimento do processo de descentralização e democratização política, ocorreram situações em que diversas iniciativas locais por parte do poder público e organizações civis buscaram fomentar por diferentes meios o desenvolvimento de projetos habitacionais autogeridos.
}

Após a gestão petista, o programa foi suspenso e criminalizado pelas gestões seguintes (1993 - 2000). O repasse de recursos às entidades foi paralisado e, em consequência, as obras também. Os movimentos resistiram ao desmonte do programa, com diversas atividades, como acampamentos na frente da sede da prefeitura. A prefeitura, por sua vez, junto com o Tribunal de Contas do Município, pediu a auditoria das contas dos mutirões, em um processo que levou mais de cinco anos. Apenas em 1998, algumas obras foram lentamente retomadas e ainda de forma pontual. 


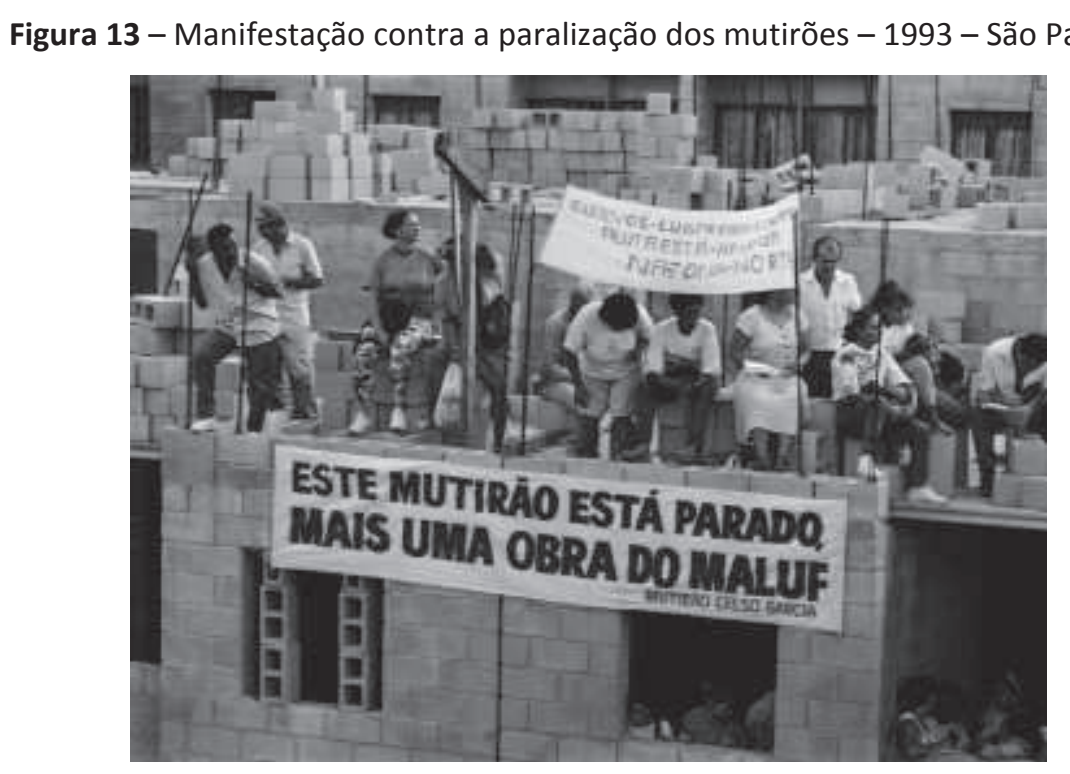

Foto: Douglas Mansur

O programa somente foi retomado durante nova gestão do Partido dos Trabalhadores (PT) de 2001 a 2004, quando a primeira preocupação foi o atendimento do passivo de unidades da primeira gestão, ainda inconclusas, com projetos deteriorados ou ocupados de forma precária pelas próprias famílias, que concluíram as unidades com recursos próprios. Novo programa foi reestruturado, ajustado a questões apreendidas durante os anos passados.

A experiência da capital paulista, no início da década de 1990, influenciou diversas outras ações. Em 1991, fortalecidos pelas ações em curso na Prefeitura de São Paulo, a União dos Movimentos de Moradia (UMM) conquista linha de financiamento para mutirões do governo do estado. Pontual e informalmente chamado de Programa de Mutirões - UMM, possuía a característica de ser apenas uma forma de dar resposta às pressões do movimento. Somente a partir de 1995, o governo de São Paulo cria o Programa Paulista de Mutirões, com regras pré-estabelecidas e maior amplitude de entidades atendidas. 
Figura 14 - Mutirão União da Juta - Financiamento CDHU - São Paulo-SP - 1998

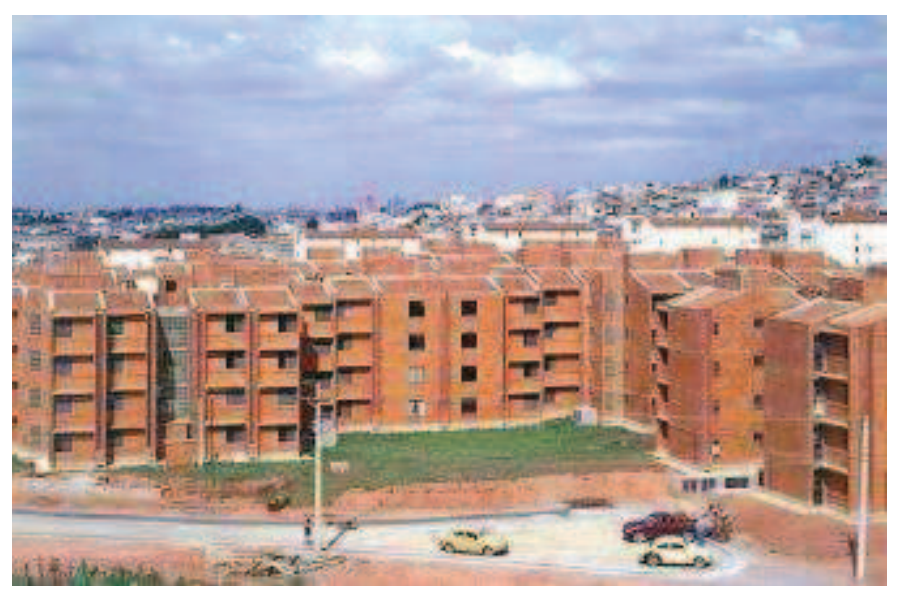

Fonte: Acervo UNMP

Figura 15 - Mutirão Vila Albertina - Financiamento CDHU - São Paulo-SP

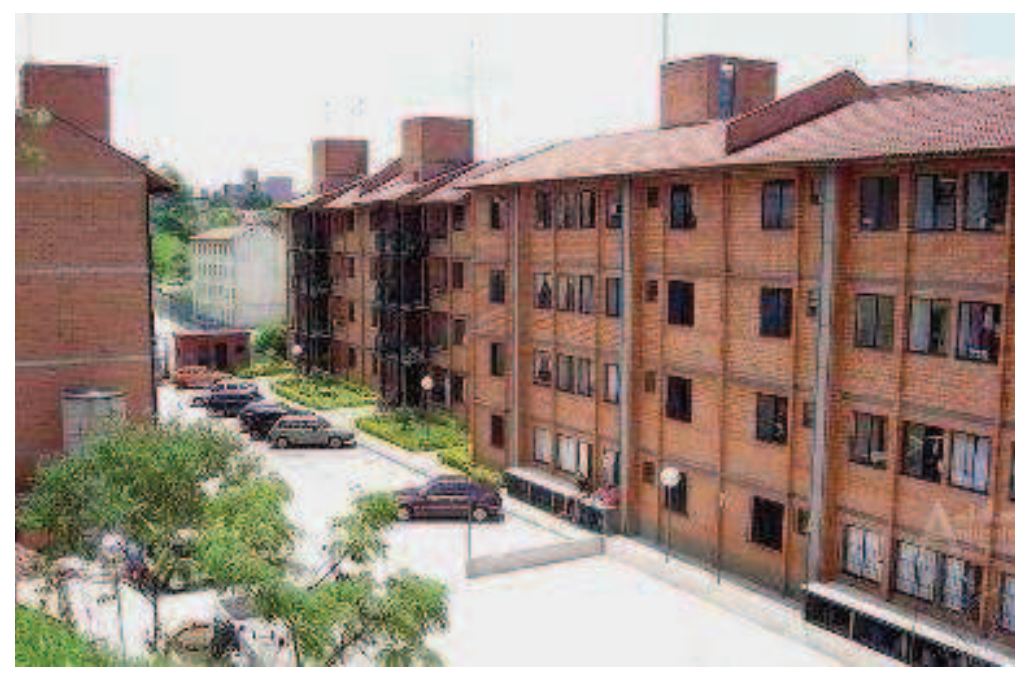

Fonte: Ambiente Assessoria Técnica

No entanto, o programa engessa cada vez mais as possibilidades de autogestão, pressionando para que as entidades não elaborassem seus próprios projetos, mas construíssem com as tipologias já elaborados pela $\mathrm{CDHU}$, dificultando a aprovação de novos projetos ou até, nas situações mais limites, impondo às associações a contratação de determinada empresa para a execução dos empreendimentos.

Nesse momento, apesar de o programa ter chegado a cerca de 21 mil unidades construídas ${ }^{14}$, identificam-se várias práticas que apenas utilizam os recursos do programa, sem ter, de fato, adotado a prática autogestionária. O programa manteve certo vigor, até o

\footnotetext{
${ }^{14}$ Fonte: <www.cdhu.sp.gov.br>. Acesso em: 20 jun. 2012.
} 
ano de 2000 e, apesar do mesmo partido permanecer à frente do governo estadual, foi sendo gradativamente extinto.

Questão a ser considerada nesses dois momentos, e observada em outras localidades também, é a descontinuidade das políticas públicas e de sua forma de implementação. Os programas de apoio à autogestão sofrem momentos de avanço e refluxo, o que impede a consolidação e estruturação dos seus agentes: tanto associações, movimentos, quanto as assessorias técnicas viveram na incerteza da continuidade ou não dos programas de financiamento. Ainda assim, a proposta autogestionária sobrevive e permanece na agenda política dos movimentos de moradia.

\subsection{Autogestão e direito à cidade}

Ao longo dessa trajetória, os movimentos de moradia também passam a interagir com outros atores e setores das lutas urbanas, tanto nas iniciativas comunitárias por melhorias nos bairros de sua atuação como na incidência em políticas públicas. Nesse processo, foram se ampliando a agenda de lutas e a prática cotidiana. Da mobilização social realizada em torno da Emenda Popular da Reforma Urbana ${ }^{15}$ apresentada à Assembleia Constituinte, pelo Movimento Nacional da Reforma Urbana, resulta o capítulo urbano, que corresponde aos artigos 182 e 183 da Constituição Federal.

Consequência da articulação em torno da Emenda Constitucional da Reforma Urbana, como aponta De Grazia (2002), foi a formação do Fórum Nacional de Reforma Urbana (FNRU), atuante até os dias de hoje. Santos Jr. reflete sobre esse processo:

A questão é reconhecer que nesse processo que combinou lutas sociais e reflexões conceituais desenvolveu um novo paradigma, ou mais precisamente, as bases de um novo paradigma, que podemos denominar da cidade-direito, ligado ao campo da reforma urbana, que tem se caracterizado pela construção de diagnósticos

\footnotetext{
${ }^{15}$ A Emenda Popular pela Reforma Urbana foi apresentada por um conjunto de movimentos, ONGs, entidades sindicais, entre outros, com cerca de 200 mil assinaturas.
} 
críticos da questão urbana brasileira e pela proposição de estratégicas para um projeto alternativo de cidades ${ }^{16}$.

Nesse sentido, ao lado das demandas já tradicionais do movimento de moradia, como o Fundo Nacional de Moradia e a prioridade de atendimento às famílias de baixa renda, outras bandeiras de luta foram incorporadas, como explica Cardoso (2003, p. 31):

\begin{abstract}
A proposta do Movimento Nacional da Reforma Urbana se centrou principalmente em termos da definição de uma nova esfera de direitos - os direitos urbanos diretamente ligados ao papel do Estado na garantia da reprodução social, e na defesa de uma nova concepção de democracia, pautada na participação popular na gestão da cidade. Estes princípios envolviam, ainda, necessariamente, uma maior regulação da ação dos capitais privados no urbano, o que se expressa principalmente através da ideia de limitação ao direito de propriedade.
\end{abstract}

O FNRU passa a desenvolver, de forma paralela e simultânea, ações no campo da mobilização e difusão dos conceitos da reforma urbana, bem como uma agenda institucional, junto ao Congresso Nacional e, a partir de 2003, ao Ministério das Cidades. Os melhores e mais evidentes exemplos dessa atuação no campo institucional foram as mobilizações pela aprovação das leis do Estatuto da Cidade (Lei 10.257/2001) e o Sistema Nacional de Habitação de Interesse Social (Lei 11.124/2005) e também a atuação nas Conferências ${ }^{17}$ e no Conselho Nacional das Cidades ${ }^{18}$.

O FNRU acompanha e incide diretamente nas discussões que levaram à aprovação do Estatuto da Cidade, como conta Bassul ${ }^{19}$, desde sua proposição até a sanção presidencial, fazendo a interlocução das discussões dos movimentos sociais com os demais segmentos envolvidos, especialmente o do capital imobiliário.

\footnotetext{
${ }^{16}$ SANTOS JÚNIOR, Orlando A. dos. Reforma urbana: desafios para o planejamento como práxis transformadora. In: COSTA, Geraldo M.; MENDONÇA, Jupira G. de (Org.). Planejamento urbano no Brasil: trajetórias, avanços e perspectivas. Belo Horizonte: C/Arte, 2008. p. 8.

${ }^{17}$ As Conferências Nacionais das Cidades foram instituídas por decreto presidencial, em 2003. A Conferência Nacional é precedida de etapas municipais e estaduais e elege o Conselho Nacional das Cidades. Cada conferência tem um tema central e eixos de discussão. Em 2013, é realizada a 5a Conferência Nacional das Cidades, com o tema Quem Muda a Cidade Somos Nós: Reforma Urbana já!.

18 O Conselho Nacional das Cidades é composto por 86 membros titulares e 86 suplentes, com maioria da sociedade civil e é um "colegiado de natureza deliberativa e consultiva, integrante da estrutura do Ministério das Cidades e tem por finalidade estudar e propor diretrizes para a formulação e implementação da PNDU, bem como acompanhar a sua execução". Disponível em: <http://www.cidades.gov.br/5conferencia/conselhodas-cidades/o-conselho.html>.

${ }^{19}$ BASSUL, José Roberto. Estatuto da Cidade: a construção de uma lei. In: CARVALHO, Celso Santos; ROSSBACH, Ana Claudia (Org.). O estatuto da cidade comentado. São Paulo: Aliança das Cidades, 2010. 120p.
} 
As Conferências Nacionais das Cidades e o Conselho Nacional das Cidades também têm sido processos em que se abre a possibilidade de diferentes grupos debaterem suas propostas e construirem políticas, junto com o poder público. Os processos, muitas vezes longos, contribuem também para que os movimentos ampliem sua visão da cidade e tenham um olhar mais abrangente sobre o papel da sociedade civil. No ConCidades, as entidades convivem com uma pauta que, se ainda é marcada por questões setoriais, exige o diálogo e a mediação entre esses setores.

Hoje, o FNRU está organizado em todo o Brasil e, desde 1987, atua na mobilização, capacitação e articulação dos atores políticos locais para a participação e a incidência nas políticas da reforma urbana, e também possui uma agenda nacional. As bandeiras atuais do FNRU são:

\begin{abstract}
a participação popular e o controle social; a moradia digna para todos e todas; a prevenção de despejos, deslocamentos e remoções coletivas de impacto social e mediação dos conflitos fundiários, com respeito aos direitos humanos; a regularização fundiária das favelas e ocupações; a integração dos projetos urbanos e investimentos em infraestrutura urbana com o planejamento das cidades; a garantia da implementação de uma política nacional de saneamento ambiental; a implantação da mobilidade sustentável e cidadã no país; a garantia da acessibilidade às pessoas com deficiência; a elaboração de políticas públicas de segurança pública, geração de emprego e renda e de combate à discriminação de grupos sociais e étnico-raciais que tenham como base os direitos humanos ${ }^{20}$.
\end{abstract}

Os movimentos populares traduziram essa agenda para as lutas cotidianas, como o reconhecimento do direito à cidade como fundamental; a preocupação não só com a casa, mas com a qualidade de vida, traduzida em infraestrutura, equipamentos sociais, acesso a transporte, geração de emprego e renda, alternativas coletivas e cooperativas de gestão dos equipamentos públicos e das áreas comerciais e de produção.

A defesa do direito à cidade dá-se também no questionamento de que somente as áreas distantes e desvalorizadas são os espaços "destinados" para os mais pobres, na resistência aos despejos e na mobilização contra projetos autoritários de caráter higienista e excludentes apresentados pelos poderes públicos para as cidades. De certa forma, estendem-se os conceitos apreendidos no exercício da autogestão para a esfera pública, sob

\footnotetext{
${ }^{20}$ FNRU. Plataforma do direito à cidade e reforma urbana: caminho para cidades justas democráticas e sustentáveis. São Paulo, 2012
} 
a forma de controle social, reivindicando não somente o direito, mas a participação nas decisões sobre a cidade.

A UNMP (2006, p. 4), em seu 10ํㅡㄹ Encontro, afirma que

A carência habitacional está no centro do nosso problema urbano já que, em razão da exclusão de grande parte da população do mercado imobiliário formal, cresce o déficit habitacional e as formas de inserção marginal na cidade. Prevalecem as lógicas perversas, produtoras da maior parte dos chamados problemas urbanos: quem está fora do mercado só tem acesso à moradia à margem da cidade! A nossa urbanização, em consequência, é caracterizada pelo permanente e crescente descompasso entre o crescimento das cidades e a veloz expansão das suas margens.

Dentre as propostas, defendem que a política habitacional e as ações dos movimentos devem ocupar os vazios urbanos, edifícios e as fábricas ociosos das cidades; e que seja aplicado o capítulo constitucional da reforma urbana, impedindo que as áreas que não cumpram sua função social permaneçam desocupadas e também que as desapropriações não deem lucro ao capital imobiliário. Também na pauta está a luta pela regularização de áreas e moradias ocupadas, com programas de urbanização e melhorias habitacionais.

\footnotetext{
Lutar pela função social da propriedade como eixo de uma política urbana inclusiva que modifique a nossa realidade pela implementação combinada dos diversos instrumentos de reforma urbana, visando à regulação pública da propriedade privada, à justa distribuição dos custos e benefícios do processo de urbanização, ao reconhecimento da cidade informal, à gestão democrática e ao desenvolvimento sustentável (UNMP, 2006, p.8).
}

\subsection{Articulações em nível internacional}

Nessa trajetória, os movimentos e as demais entidades também se articularam com organizações internacionais. Nesses espaços, prioriza-se o intercâmbio de experiências, mas também se busca construir uma agenda comum, que contemple as ações de um mundo cada vez mais globalizado. 
A Secretaria Latino-Americana de la Vivienda Popular (Selvip) é uma organização formada na década de 1990, exclusivamente por movimentos populares ${ }^{21}$ que defendem a proposta autogestionária e teve influência na formatação da proposta brasileira, especialmente com a experiência uruguaia, trazida pela Fucvam. Nesses mais de 20 anos, a Selvip, além de apoiar a construção de propostas autogestionárias em diversos países, tem atuado no fortalecimento dos movimentos populares anticapitalistas. Atualmente, a Selvip desenvolve uma Escola Latino-Americana de Autogestão Popular, como estratégia de difusão da proposta e atualização de sua agenda política.

Diversas organizações do FNRU participam da Coalizão Internacional do Hábitat (HIC), que reúne movimentos sociais, ONGs, universidades e ativistas de lutas urbanas ${ }^{22}$. A HIC tem centrado sua pauta na defesa do direito à terra e à moradia, no apoio e na reflexão sobre a Produção Social do Hábitat e na mobilização da solidariedade na luta contra os despejos e atua em campanhas, mobilizações, construção de reflexão coletiva, apoio à documentação e difusão desses temas, bem como na interlocução com organismos internacionais, como a Agência Hábitat e Alto Comissário das Nações Unidas para os Direitos Humanos.

A partir do 1ำ Fórum Social Mundial, tem início a formulação de uma Carta Mundial do Direito à Cidade, iniciativa do Fórum Nacional de Reforma Urbana, ampliada por inúmeras redes internacionais que se somaram ao longo do processo. A Carta propõe o reconhecimento, no sistema internacional de direitos humanos, do Direito à Cidade, definido como:

o usufruto equitativo das cidades dentro dos princípios da sustentabilidade e da justiça social. Entendido como o direito coletivo dos habitantes das cidades em especial dos grupos vulneráveis e desfavorecidos, que se conferem legitimidade de ação e de organização, baseado nos usos e costumes, com o objetivo de alcançar o pleno exercício do direito a um padrão de vida adequado ${ }^{23}$.

\footnotetext{
${ }^{21}$ Integram, hoje, a Selvip: a União Nacional por Moradia Popular, Movimiento de Ocupantes e Inquilinos-CTA, Federación Tierra Vivienda y Hábitat, Red de Hábitat Popular Chile, Federación Nacional de Pobladores, Federación Uruguaya de Cooperativas de Vivienda por Ayuda Mutua, Movimiento de Pobladores y Pobladoras de Venezuela e SOLIDARIDAD Asociación de Cooperativas Múltiples de Quito.

${ }^{22}$ A HIC foi fundada em 1976, por ocasião da I Conferência das Nações Unidas sobre Assentamentos Humanos e, hoje, reúne cerca de 350 organizações, em 80 países.

${ }^{23}$ Disponível em: <http://www.forumreformaurbana.org.br/index.php/documentos-do-fnru/41-cartas-emanifestos/133-carta-mundial-pelo-direito-a-cidade.html>. Acesso em: 20 dez. 2012.
} 
A Carta Mundial pelo Direito à Cidade é outro exemplo de agenda que passa a integrar o discurso e a pauta dos movimentos populares, integrando a luta por moradia às demais lutas urbanas.

A UNMP participa também, de 2006 a 2008, de um esforço coletivo do Centro Cooperativo Sueco (SCC), envolvendo organizações populares que atuam com autogestão habitacional de 14 países da America Latina ${ }^{24}$, para a construção de uma Estratégia Regional de Acesso ao Solo Urbanizado. Esse grupo, além de empreender um diagnóstico regional, considera as características locais, mas atentando fundamentalmente para os aspectos comuns desses países, a partir da realidade apreendida nos assentamentos precários e nas restrições de acesso ao solo.

\begin{abstract}
Mas a terra é um bem inelástico, não se reproduz, é a que existe, e, por isso, se instala a luta por ela: primeiro, a grande maioria, por apenas um lugar para viver, e, de outro, uma minoria com voracidade de lucrar com ela, fazendo que se torne uma mercadoria. Assim ocorre uma luta sem quartel: entre a terra como um direito ou como uma mercadoria. (SCC, 2012, p. 232).
\end{abstract}

O trabalho foi apresentado publicamente em um manifesto das organizações participantes e do SCC. O documento propõe 28 estratégias, que reafirmam a luta pelo cumprimento da função social da propriedade, da desmercantilização do solo urbano, da recuperação das mais-valias fundiárias, do reconhecimento de formas de posse comunitárias e informais e da criação de políticas públicas para a destinação de terra urbanizada para moradia popular.

\footnotetext{
${ }^{24}$ Movimiento Urbano Popular (MUP), México; União Nacional por Moradia Popular, Brasil; Grupo promotor de pobladores del centro histórico, Peru; Federación de Inquilinos y Vivienda de Tarija (Fedinvit), Bolívia; Codeca, Comunidad La Carpio, Costa Rica; Central de Cooperativas de Vivienda, Paraguai; Federación Uruguaya de Cooperativas de Vivienda por Ayuda Mutua (Fucvam), Uruguai; Federación Tierra y Vivienda (FTV), Argentina; Movimiento Ocupantes Inquilinos (MOI), Argentina; Grupo de Pobladores de Vivienda, República Dominicana; Federación de Cooperativas de Vivienda (Fecovi), Equador; Comité Hondureño de Vivienda Solidaria (Cohvisol), Honduras; Central de Cooperativas de Vivienda, Nicarágua; Movimiento Comunal Nicaraguense, Nicarágua; Movimiento Guatemalteco de Pobladores, Guatemala; Mesa de Cooperativas, Guatemala; Plataforma Urbana, Guatemala; Mesa de Coordinación de las Cooperativas de Vivienda, El Salvador; Comisión Nacional de Pobladores (Conapo), EL Salvador; Equipos Técnicos de Fundasal, El Salvador; Ceprodel, Nicarágua; Icade, Honduras; Fuprovi, Costa Rica; Idesac, Guatemala; e a Hábitat International Coalition (HIC).
} 
2 A AUTOGESTÃO HABITACIONAL NO GOVERNO FEDERAL 


\subsection{Política Habitacional no Brasil}

O fim do Banco Nacional de Habitação (BNH), em 1986, é considerado um marco na política habitacional brasileira. Se, no âmbito federal, a extinção não significa uma mudança na política, com a Caixa Econômica Federal (Caixa) assumindo parte do papel do BNH e o Sistema Financeiro de Habitação permanecendo vigente, o ambiente da democratização, as pressões sociais e as ações municipalistas forjam novas propostas, questionando a centralização e o modelo de produção e financiamento em vigor.

No período da ditadura, o BNH concentra as ações do poder público no campo da habitação, área estruturada em torno da concessão de financiamentos habitacionais no chamado Sistema Financeiro de Habitação (SFH), com recursos oriundos do Fundo de Garantia do Tempo de Serviço (FGTS), fundo compulsório dos trabalhadores, e do Sistema Brasileiro de Poupança e Empréstimo (SPBE), constituído por recursos das poupanças individuais. Esse Sistema, que sobrevive ao fim do BNH, portanto, nunca contou com recursos orçamentários e pouco atendeu aos extratos de renda mais baixa da população.

O fim do BNH, o novo cenário democrático e a nova Constituição de 1988, com maior protagonismo dos municípios e sob pressão das demandas dos movimentos populares em nível local, marca nova fase da política habitacional. Outros agentes, como estados, municípios e até outros órgãos do governo federal, passam a desenvolver ações no campo da habitação.

\footnotetext{
Neste quadro, emerge um amplo conjunto de experiências municipais de habitação de interesse social, realizadas a partir da redemocratização do país. (...) ocorre, nas esferas municipal e estadual, uma fase de atomização de experiências, com grande heterogeneidade, marcada pela diversidade de iniciativas, mas pouco articulada em decorrência da ausência de uma política nacional. (BONDUKI, 2008, p. 77).
}

A partir desses novos agentes aparecem programas locais, como a urbanização de favelas e regularização fundiária de assentamentos precários, programas autogestionários de produção habitacional, programas habitacionais em áreas centrais, entre outros. Essas práticas não só atendem a uma parcela até então excluída das políticas oficiais, como também assentam as bases para as elaborações posteriores dessa política. 
Em 1991, os movimentos populares de luta por moradia, somados a um grande número de entidades sindicais, ONGs e igrejas, apresentam o primeiro projeto de lei de iniciativa popular, que cria o Fundo Nacional de Moradia Popular, em uma mobilização que reúne um milhão de assinaturas e propicia amplo debate sobre a reformulação da política nacional de habitação.

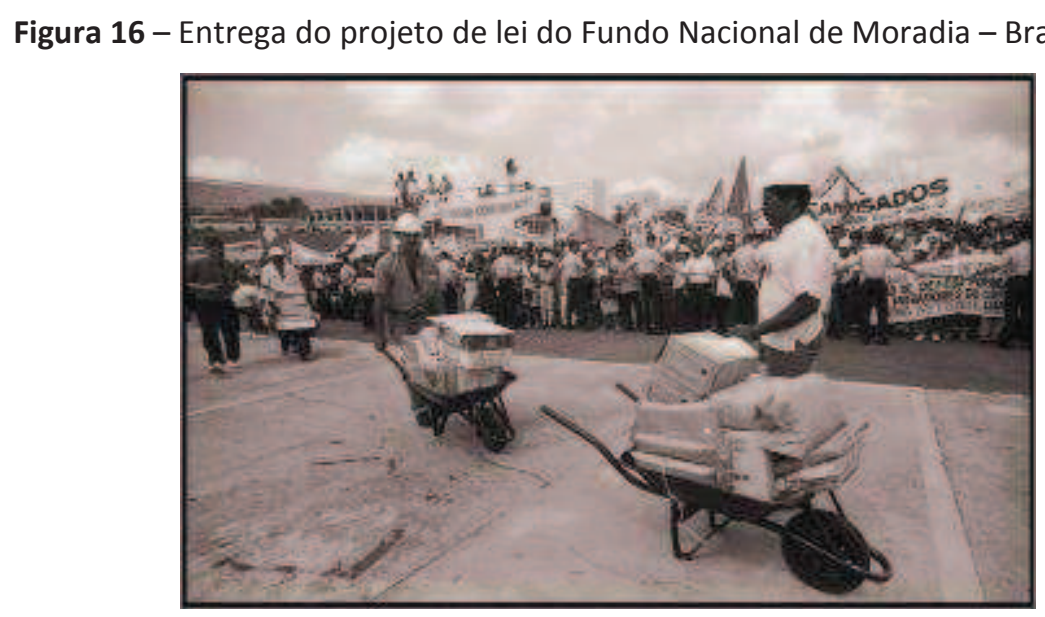

Foto: Douglas Mansur

Alguns dos aspectos principais do projeto de lei envolvem a prioridade para a habitação destinada à população de baixa renda, o controle social nos diferentes níveis e a articulação de governo federal, estados e municípios na política habitacional, conforme estabelece a Constituição de 1988. Em 1994, em documento que sintetiza as bases da política habitacional proposta pelos movimentos, a UMM defende as "responsabilidades diferentes e complementares entre as esferas públicas ${ }^{25}$, com competências bem definidas de cada um dos agentes, participação da sociedade civil e o mix de recursos onerosos e subsidiados, permitindo "uma política de financiamento de caráter social, com subsídios às famílias de baixa renda ${ }^{26 \prime}$. Essa pauta, ainda que com diversas atualizações, permanece vigente na agenda política dos movimentos sociais até os dias atuais.

Somente em 1995, durante a gestão de Fernando Henrique Cardoso, e quase dez anos após o fechamento do BNH, o governo federal lança uma Política Nacional de Habitação, centrada em financiamentos habitacionais ao beneficiário de forma individual,

\footnotetext{
25 UMM. Bases de uma política habitacional. 1994, p. 14.

${ }^{26}$ Idem, p. 12
} 
para que buscasse seu imóvel no mercado ${ }^{27}$. Na sequência, é criada a Carta de Crédito Associativa, modalidade em que cooperativas, sindicatos, entidades ou Cohabs podem organizar demanda para financiar empreendimentos a serem edificados por construtoras.

Essa política já contém elementos no campo da urbanização de assentamentos precários e melhorias habitacionais, mas com poucos recursos orçamentários ou de financiamento disponíveis. Segundo Bonduki (2008, p. 81),

o ajuste fiscal consolidou-se como principal obstáculo à realização de investimentos voltados para a urbanização e a produção de moradias destinadas ao atendimento dos segmentos de mais baixa renda, onde se encontra concentrado o grosso das necessidades habitacionais do país.

Dessa maneira, os resultados quantitativos, vinculados ao atendimento desse segmento, são pouco expressivos e a maior parte dos investimentos destinados ao segmento de renda média. Ainda nessa gestão, em 2001, é criado o Programa de Arrendamento Residencial $(P A R)^{28}$, para atuar exclusivamente em grandes centros urbanos.

Entre 1998 e 2000, o Instituto Cidadania, espaço de formulação de propostas para políticas públicas do PT, elabora o Projeto Moradia $^{29}$, que buscava construir uma proposta integral para a política de habitação. O projeto reúne o acúmulo de discussões realizadas no âmbito dos movimentos sociais, das conferências das cidades organizadas pela Câmara dos Deputados e ocorridas internamente no PT, e foi base para, na primeira gestão do presidente Lula, a criação do Ministério das Cidades e da política nacional de habitação.

A partir de 2003, durante a gestão do presidente Lula, diversas iniciativas passam a ser implementadas nessa área, com a criação do Ministério das Cidades. Em 2004, o Conselho Nacional das Cidades aprova a Política Nacional de Habitação, que, ao lado de um conjunto de ações para a urbanização de assentamentos precários e produção habitacional para as faixas mais baixas de renda, propunha também melhor regulação do mercado imobiliário, para atender aos setores médio e médio-baixo, de forma que deixassem de

\footnotetext{
${ }^{27}$ A Resolução 184, de 1ํ de agosto de 1995, do Conselho Curador do FGTS, criou a Carta de Crédito Individual, para dar financiamento do FGTS diretamente ao beneficiário interessado em adquirir seu imóvel no mercado. ${ }^{28}$ Programa de arrendamento residencial com o beneficiário, com opção de compra ao final do período contratado.

${ }^{29}$ A coordenação-geral foi da arquiteta e ex-deputada estadual Clara Ant. Participaram da coordenação do projeto André Luiz de Souza, Ermínia Maricato, Evaniza Rodrigues, lara Bernardi, Lúcio Kowarick, Nabil Bonduki e Pedro Paulo Martoni Branco.
} 
recorrer aos poucos recursos públicos destinados à habitação. Faz parte dessas iniciativas, a edição da Lei federal 10.391/2004, que regulamenta o patrimônio de afetação das empresas na construção e a adoção da alienação fiduciária, como figura central para as garantias dos financiamentos.

De forma paralela, o Ministério das Cidades dá continuidade e aprimora os demais programas já existentes, como o Programa de Subsídio Habitacional e a utilização de recursos do FGTS, principalmente com as Cartas de Crédito Individuais e Coletivas e o crédito para material de construção para reformas. O FGTS é responsável por importante inovação, ou seja, a utilização de recursos do seu patrimônio líquido para subsidiar financiamentos habitacionais, conhecida como Resolução $460^{30}$.

Com esse arranjo, parte do recurso para a provisão habitacional era onerosa e parte a fundo perdido. Em diversos casos, o próprio município assume a parte onerosa de empréstimo do Fundo, atendendo a famílias de mais baixa renda, que não poderiam arcar com um financiamento. O programa Operações Coletivas atende às demandas dos municípios, especialmente os de pequeno porte e também de algumas associações e cooperativas locais. O único programa novo criado na primeira gestão do presidente Lula, foi o Crédito Solidário, que será abordado adiante.

Após intensa pressão junto ao governo federal, é aprovada a Lei 11.124/2005, que cria o Sistema Nacional de Habitação de Interesse Social (SNHIS), após 13 anos de tramitação no Congresso Nacional. Havia um entendimento, por parte dos atores sociais, de que o Fundo Nacional de Habitação de Interesse Social (FNHIS) centralizaria os recursos e os programas de urbanização de assentamentos precários e produção habitacional de baixa renda.

No entanto, a conformação do FNHIS, concebido como "fundo orçamentário", deuIhe algumas restrições, a principal delas relacionada à origem de recursos, que, apesar de formalmente poder receber outras fontes, na prática, se restringiu ao Orçamento Geral da União (OGU). Esses recursos, além de estarem sujeitos a contingenciamentos orçamentários,

\footnotetext{
${ }^{30}$ Trata-se da Resolução do CCFGTS 460, de 14 de dezembro de 2004.
} 
determinaram o atrelamento da operação do FNHIS às regras de repasse do $O G U^{31}$, condicionando os repasses de recursos agentes promotores (estados e municípios), prevendo uma série de regras, entre elas a gestão do processo e a licitação de executores.

Com isso, as principais fontes de recursos utilizadas na habitação, especialmente o FGTS, integraram o SNHIS, mas não o FNHIS, como propunham os movimentos sociais desde a proposição do FNMP, em 1991. Essa questão passou a ser central na discussão da política habitacional. Em dezembro de 2006, a UNMP apresentou documento ao presidente Lula que acabara de ser reeleito, com diversas propostas e reivindicações, dentre elas:

\footnotetext{
- O Conselho Nacional das Cidades é o órgão central da política e deve ter caráter deliberativo;

- Toda a política de habitação deve ser debatida e aprovada pelo ConCidades, evitando "pacotes" unilaterais do governo;

- O Fundo Nacional de Habitação de Interesse Social deve reunir todos os recursos destinados à população de baixa renda, não apenas os orçamentários ${ }^{32}$.
}

A questão explicita-se quando, em janeiro de 2007, o governo federal lança o Programa de Aceleração do Crescimento (PAC) Urbanização com recursos do OGU e fora do FNHIS, sob a alegação de que o programa exigia agilidade e gerando inúmeras críticas dos movimentos sociais. O PAC adota um regime diferenciado de contratação, que, segundo o governo, não seria possível dentro do FNHIS. Uma das questões ressaltadas pelos movimentos é que os recursos do FNHIS são geridos pelo Conselho Gestor do FNHIS ${ }^{33}$ e que, portanto, os do PAC não teriam nenhum controle social e nem atendem às exigências operacionais do $\mathrm{FNHIS}^{34}$.

Em paralelo a esse processo, o SNHIS foi sendo implementado, com a adesão dos estados e municípios, e a elaboração do Plano Nacional de Habitação (PlanHab) pela Secretaria Nacional de Habitação, através da contratação de uma consultoria, em um processo que conta com a participação de diversos atores sociais, entre 2007 e 2008, através

\footnotetext{
31 Portarias do Ministério do Planejamento regem o repasse de recursos do OGU e vinculam os repasses ao cumprimento da Lei de Licitações (Lei 8.666/1993).

32 UNMP. Documento ao presidente Lula. dez. 2006.

33 O CGFNHIS é composto por 24 membros, metade deles do governo federal e metade da sociedade civil, eleitos pelo ConCidades.

${ }^{34}$ Para aderir ao SNHIS, o estado ou município deve criar um conselho e um fundo de habitação e elaborar um plano de habitação. Esses são requisitos para que o ente tenha acesso a recursos do FNHIS.
} 
de um grupo de acompanhamento integrado por membros do Conselho Nacional das Cidades e de reuniões com diferentes segmentos, regiões do País e temas.

O PlanHab estruturou, a partir dos princípios e diretrizes da Política Nacional de Habitação e da estrutura criada pelo SNHIS, propostas e metas para a solução da carência habitacional, quantitativa e qualitativamente, até o ano de 2023, através de quatro eixos: Financiamento e subsídio; Arranjos institucionais; Estratégias urbanas e fundiárias; e Cadeia Produtiva da Construção Civil.

O programa Minha Casa Minha Vida apropriou-se, em seu lançamento, de parte das propostas do PlanHab, especialmente naquelas que se referem à oferta de recursos subsidiados para HIS e de mecanismos de financiamento para os Grupos 2 e 3, mas não a totalidade de suas propostas, especialmente no que se refere à construção de uma política de habitação centrada na articulação entre os diferentes níveis de governo e nas estratégias urbanas e fundiárias.

\subsubsection{Minha Casa Minha Vida}

No final de 2008, com a crise financeira mundial, o governo começa a gestar um novo pacote habitacional. As empresas da área de construção, que vivenciaram um verdadeiro boom imobiliário nos anos anteriores, abrindo seus capitais na bolsa de valores e com uma série de recursos investidos no lançamento de imóveis residenciais, se viram diretamente afetadas pela crise.

O governo, também preocupado com os efeitos da crise, especialmente o risco de desemprego, e pressionado diretamente pela indústria da construção, passa a construir o que foi chamado de programa Minha Casa Minha Vida (MCMV). A condução das negociações com o setor foi feita pela então ministra chefe da Casa Civil, Dilma Roussef, que recebeu as propostas formatadas por grandes empresas, para definir o programa. Ao final do processo, outros segmentos, como prefeituras, governos estaduais e movimentos sociais também apresentaram suas propostas, mas a estrutura do programa já estava definida. 
O programa lança a bandeira da construção de 1 milhão de casas e anuncia o aporte de $R \$ 34$ bilhões, grande parte em subsídios, quantidade de recursos inéditos para o setor. $O$ MCMV é apresentado como uma política anticíclica, frente à crise econômica mundial de 2009, no intento de evitar a recessão e o desemprego no País. Fix (2011, p. 141) demonstra a dupla justificativa para tais investimentos:

[O programa] Responde, a um só tempo, a problemas de acumulação, por meio da injeção de recursos no circuito imobiliário (construção de edificações e construção pesada, indústria de materiais e componentes, mercado de terras) e legitimação, ao responder à pressão das lutas sociais do ponto de vista da demanda por habitação e por emprego.

O MCMV é um conjunto de programas habitacionais do governo federal, com diferentes fontes de recursos e faixas de renda atendidas. Encontram-se diferentes tipos de produção habitacional, sob a etiqueta. A primeira etapa do programa compreende o período de 2009 a 2010. Instituída pela Medida Provisória 459, de 25 de março de 2009, posteriormente é convertida na Lei 11.977, de 7 de julho de 2009, e demais normas infra legais. A segunda etapa do programa (MCMV 2), iniciada em 2011 e regulamentada pela Lei 12.424, de 16 de junho, propõe a construção de 2,4 milhões de moradias. O MCMV divide as moradias produzidas em três faixas de renda, com diferentes programas e fontes de recursos.

Figura 17 - Lançamento do Programa Minha Casa Minha Vida - 2009

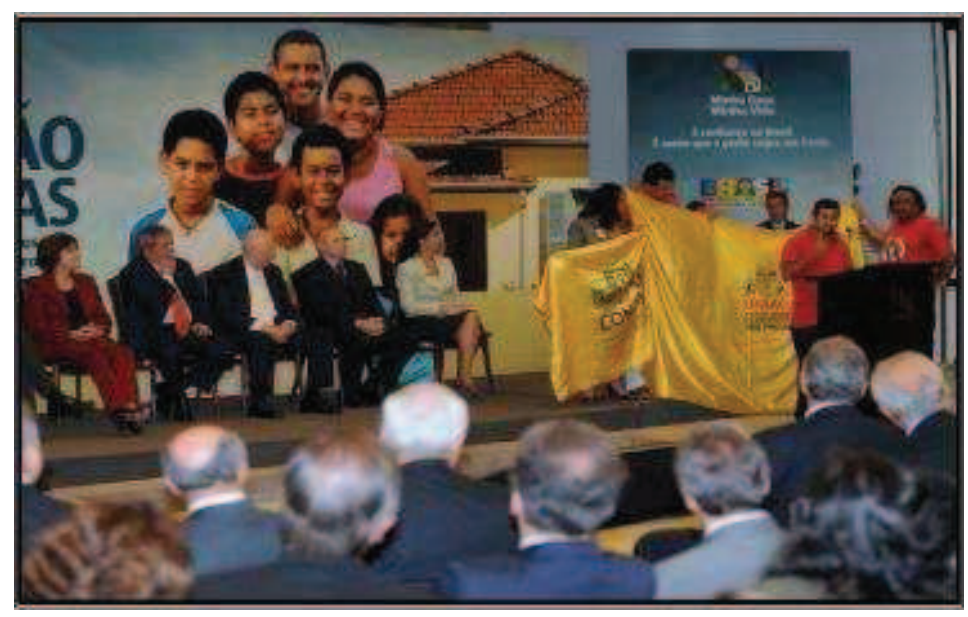

Fonte: Acervo da UNMP

O Programa Nacional de Habitação Urbana (PNHU), o Minha Casa Minha Vida Entidades (MCMV-E) e o Programa Nacional de Habitação Rural (PNHR) - Grupo 1 são 
destinados à Faixa 1 (Tabela 1) e têm como fonte de recursos, exclusivamente, o OGU. As demais faixas têm recursos do FGTS, sendo que a Faixa 2 também conta com subsídios do FGTS e do OGU. Posteriormente, no Congresso Nacional, quando é aprovada a Medida Provisória, cria-se a Oferta Pública de Recursos, para a Faixa 1, destinada a municípios com população inferior a 50 mil habitantes, conhecido como Sub 50. Além da alocação de subsídios, o programa MCMV também desonera parte da cadeia da indústria da construção, com um regime especial de tributação ${ }^{35}$ e, em novembro de 2012, anuncia também a redução dos encargos previdenciários da folha de pagamento das empresas da construção ${ }^{36}$.

Tabela 1 - Metas e modalidades do programa Minha Casa Minha Vida

\begin{tabular}{|c|c|c|c|c|c|}
\hline \multirow[t]{4}{*}{ aixa } & Em R\$ & $\begin{array}{l}\text { Em salários- } \\
\text { mínimos }^{a}\end{array}$ & $\begin{array}{l}\text { Número } \\
\text { de } \\
\text { Unidades } \\
\text { MCMV } 1\end{array}$ & $\begin{array}{l}\text { Número de } \\
\text { Unidades } \\
\text { MCMV } 2\end{array}$ & Programas \\
\hline & $\begin{array}{l}\text { Até } 1.395,00 \text { - Fase } 1 \\
\text { Até } 1.600,00 \text { - Fase } 2\end{array}$ & Até 3 & 400.000 & 1.600 .000 & $\begin{array}{l}\text { PNHU - FAR, PNHE - } \\
\text { FDS, PNHR e Sub } 50\end{array}$ \\
\hline & $\begin{array}{l}1.396,00 \text { a } 2.790,00-\text { Fase } 1 \\
1.601,00 \text { a } 3.275,00-\text { Fase } 2\end{array}$ & 3 a 6 & 400.000 & 600.000 & $\begin{array}{l}\text { PNHU FGTS }{ }^{b} \text { e PNHR } \\
\text { - FGTS com subsídio }\end{array}$ \\
\hline & $\begin{array}{l}2.791,00 \text { a } 4.650,00-\text { Fase } 1 \\
3.276,00 \text { a } 5.000,00-\text { Fase } 2\end{array}$ & 6 a 10 & 200.000 & 200.000 & $\begin{array}{l}\text { PNHU FGTS }{ }^{b} \text { e PNHR - } \\
\text { FGTS }\end{array}$ \\
\hline
\end{tabular}

a Salário-mínimo vigente em março de 2009

b Inclui as modalidades Carta de Crédito, Imóvel na Planta e Financiamento à Produção.

Fonte: Ministério das Cidades, 2011.

O MCMV configura-se pela produção privada dos empreendimentos, com financiamento público, com a justificativa de que o setor da construção civil apresentaria rápida reação ao programa, diferentemente das dificuldades e burocracias enfrentadas pelo setor público. Por ocasião do lançamento do programa, Arantes e Fix (2009, p. 2-3) chamam a atenção para o fato e afirmam que

\footnotetext{
35 Instrução Normativa 934 (RFB), de 27 de abril de 2009.

${ }^{36}$ Disponível em:

<http://www.fazenda.gov.br/portugues/documentos/2012/Apresenta\%C3\%A7\%C3\%A3o Constru\%C3\%A7\%C3 \%A3o_Civil_Final.pdf>. Acesso em: 12.dez.2012
} 
A justificativa é a dificuldade do poder público (sobretudo municipal) na aplicação de recursos e a lentidão na execução do Programa de Aceleração do Crescimento (PAC), o que acabou induzindo o Governo Federal e a Casa Civil a optarem por uma produção diretamente de mercado, que dispensa em grande medida a gestão pública. Ineficiência, falta de quadros, burocratismo, restrições legais e fiscais, licitações demoradas, órgãos de fiscalização (tribunais de contas e controladorias) são, efetivamente, fatores que contribuem para a lentidão e a baixa efetividade da administração pública, que sucumbe diante da solicitação de rapidez operacional exigida pela situação emergencial de reversão da crise (e das eleições no ano que vem).

Além disso, muitos empreendimentos já projetados, ou até iniciados, destinados inicialmente ao mercado, sem compradores, já estariam sofrendo os impactos da crise. Esses empreendimentos, destinados especialmente às Faixas 2 e 3, puderam ser imediatamente absorvidos pelo programa. As principais empresas que aderiram, em seu primeiro momento, foram aquelas que já estavam atuando no "segmento econômico", no jargão do setor, que tinham aberto seu capital nos anos anteriores e adquirido estoque significativo de terrenos. Segundo Fix (2011, p. 145), "boa parte dos primeiros empreendimentos utilizou estoque de terras das empresas, área de grande extensão que, de outro modo, estaria sem destinação".

Ao lado dessa estratégia, para a Faixa 1, é criado um novo programa, inspirado no modelo de contratação do PAR, porém sem o componente do arrendamento, que concentrou a maior parte dos investimentos nessa faixa.

As únicas exceções a esse modelo são o MCMV - Entidades, o PNHR e a Oferta Pública de Recursos. Nesta, os municípios são os responsáveis em buscar o recurso por meio de edital e pela contratação. Esse programa, porém, não fazia parte do escopo original do MCMV. Esses três programas são responsáveis por apenas 13,5\% do total das unidades previstas para as duas etapas do programa.

A primeira etapa concentra esforços nas Faixas 2 e 3, com $60 \%$ das unidades habitacionais, contrariando a distribuição do déficit habitacional ${ }^{37}$, que se concentra em cerca de 90\%, na Faixa 1. Na segunda etapa do programa, o panorama sofre alteração, e

\footnotetext{
37 Dados do Déficit Habitacional no Brasil 2008, publicado pelo Ministério das Cidades e Fundação João Pinheiro. A pesquisa baseia-se no Censo Demográfico de 2000 e é atualizada com dados da Pesquisa Nacional de Amostragem de Municípios de 2008. Nesses dados, o déficit brasileiro quantitativo é de 5.546 .310 unidades, com 916.478 rurais.
} 
$62 \%$ da meta é destinada a essa faixa de renda, mas ainda distante do panorama apresentado pelo déficit ${ }^{38}$. (Tabela 2 e Gráfico 1 ).

Tabela 2 - Metas do programa Minha Casa Minha Vida versus Déficit Habitacional

\begin{tabular}{lrrr}
\hline Faixa & Déficit Urbano & MCMV 1 & MCMV 2 \\
\hline Faixa 1 & 4.148 .329 & 400.000 & 1.600 .000 \\
\hline Faixa 2 & 379.646 & 400.000 & 600.000 \\
\hline Faixa 3 & 74.077 & 200.000 & 200.000 \\
\hline Acima de 10 $^{2}$ & 27.779 & 0 & 0 \\
\hline Total $^{39}$ & 4.629 .832 & 1.000 .000 & 2.400 .000 \\
\hline
\end{tabular}

Fontes: Ministério das Cidades, 2011 e FJP, 2008

Gráfico 1 - Déficit habitacional versus metas MCMV

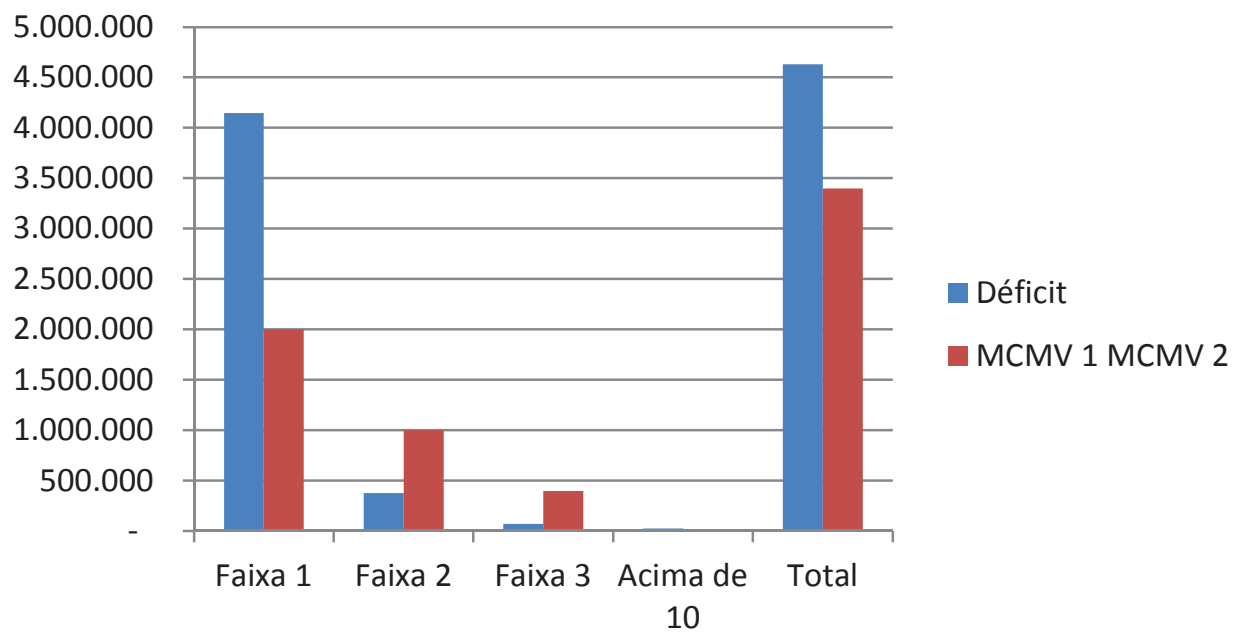

Fontes: Ministério das Cidades, 2011 e FJP, 2008

\footnotetext{
${ }^{38}$ No entanto, uma ressalva deve ser feita, especialmente ao MCMV 2, no que se refere à defasagem dos dados do déficit levantados há uma década, ainda que com algumas atualizações. Há uma premissa, utilizada pelo governo e que se confirma com os dados do censo de 2010, que houve aumento de renda dos mais pobres os quais poderiam acessar recursos destinados à Faixa 2. Entretanto, ainda não se dispõe da análise dos dados desse censo com o novo cálculo do déficit habitacional.

39 Para os dados por faixa de renda, considera-se apenas o déficit urbano, já que o rural não apresenta a mesma forma de classificação.
} 
O FNRU manifesta-se sobre o programa destacando a importância do aporte significativo de recursos para habitação social, fruto de anos de luta para o reconhecimento da moradia como um direito social. No entanto, as críticas concentram-se na concepção da proposta:

O Programa não prioriza a construção de uma política habitacional, tal qual foi concebida na lei que criou o Sistema Nacional de Habitação de Interesse Social (...). Ao invés disso, dá continuidade a uma prática que tem sido a tradição da política brasileira quando se fala em habitação: centrar na oferta de subsídios e créditos individualizados para a obtenção da propriedade privada, bem como na construção de unidades habitacionais também individualizadas, sem que as necessidades habitacionais da população de baixa renda sejam efetivamente atendidas ${ }^{40}$.

Na concepção de Cardoso, Aragão e Araújo (2011), o protagonismo do setor privado

entrou em choque com os princípios do SNHIS, pautado no papel estratégico do setor público, ignorou em larga medida premissas e debates em torno do Plano Nacional de Habitação de Interesse Social - PlanHab, então amplamente discutido em 2007. (2011, p.5).

O início da financeirização da política habitacional não pode ser atribuído ao MCMV, desde as reformulações do SFH empreendidas pelo governo de Fernando Henrique Cardoso e as medidas de regulamentação do setor habitacional, como a alienação fiduciária, vão criando o campo fértil para seu avanço. No entanto, ao injetar recursos orçamentários e de um fundo dos trabalhadores de forma massiva, o MCMV consolida essa concepção. A crítica tem se estendido a diversas políticas habitacionais atuais empreendidas na América Latina, especialmente no Chile e no México, onde

o papel do Estado (entendido como o poder público em seus diferentes níveis: Governos nacional ou federal, estaduais, departamentais ou provinciais e municipais) tem ido se limitando, de acordo com uma suposta nova concepção do seu papel, a atuar como "facilitador" da ação privada; o que e em definitiva faz que a sua intervenção somente contribua a assegurar melhores negócios às classes proprietárias, muitas vezes modificando a seu favor as normativas, assim como a sua perpetuação mediante o clientelismo ${ }^{41}$.

Mas a questão central em pauta é a habitação considerada como mercadoria, o que, segundo Ortiz (2011, p. 17), privilegia seu valor de troca, em detrimento de seu valor de uso ou sua noção de direito social.

\footnotetext{
${ }^{40}$ FNRU. Boletim a reforma urbana e o programa Minha Casa Minha Vida. 2009.

${ }^{41}$ SCC. Proposta de estratégia regional para acesso ao solo urbano. San Salvador, 2008, p.2.
} 
Este enfoque leva a conceber a moradia como produto industrial, setor econômico, tema essencialmente financeiro e patrimônio familiar. Isso implica na criação de um conjunto de instrumentos coerentes com essa visão: sistema hipotecário; mecanismos ágeis de titulação e registro da propriedade; garantias que respaldem a recuperação dos créditos; registro de destinatários e de seu histórico de crédito; sistema de informação sobre a oferta; sistema de subsídio destinado à aquisição de moradia [...] realizado por empresas privadas $)^{42}$.

No modelo do MCMV, chama a atenção a quantidade de recursos orçamentários em forma de subsídio destinada ao programa, única forma de atender à demanda de mais baixa renda, que, em determinadas situações, pode chegar a $96 \%$ do valor destinado à unidade. Ainda assim, os empreendimentos para essa faixa de renda têm as características marcadas pela produção para o mercado imobiliário.

Tanto o BNH como MCMV tratam a habitação como mercadoria a ser produzida
em moldes capitalistas. No MCMV, no entanto, os subsídios diretos ao comprador
podem ser vistos como um reconhecimento de que a habitação é um direito. Esse
reconhecimento do direito tem caráter ambíguo, uma vez que justifica a injeção de
recursos públicos em um sistema que, de resto, tem lógica privatista na definição
dos espaços, inteiramente formulados segundo os critérios de um
empreendimento imobiliário. (FIX, 2011, p. 145).

Assim, as políticas estatais atuam não só de maneira conivente, mas promotoras do conceito de mercantilização da moradia, tratando aquilo que é um direito como mais um ativo financeiro a ser disposto no mercado, regido por regras de mercado e tratando cidadãos como meros "consumidores".

Esse modelo mostra-se contraditório com as formas autogestionárias de produção habitacional. Ao se "enquadrar" em um esquema construído para outra finalidade, a autogestão perde parte de suas características, a despeito daqueles que seguem defendendo e construindo alternativas, como se verá a seguir.

\subsection{Autogestão no governo federal - projetos-piloto e pressão popular}

A proposta de criação de programas autogestionários de habitação financiados diretamente pelo governo federal está contida nas pautas dos movimentos populares desde a 1a Caravana da Moradia à Brasília, realizada em 1988. Essa reivindicação coexiste com o

\footnotetext{
42 Tradução da autora.
} 
projeto de lei de iniciativa popular de criação do Fundo Nacional de Moradia Popular, apresentado em 1991. Junto com o desenvolvimento do PL e com a proposta de um Sistema Nacional de Habitação integrando estados e municípios, a luta para que a autogestão integre a política nacional de habitação persiste na pauta política dos movimentos.

O governo federal financia poucos projetos autogestionários, sempre em resposta à pressão de movimentos populares manifestados por inúmeras caravanas, que reivindicam mudanças na política habitacional, ocorridas a partir de 1988. Apesar de terem sido bemsucedidos e avaliados, esses projetos foram pontuais e não constituíram um programa, e não têm continuidade até 2004.

Um dos primeiros empreendimentos autogestionários com financiamento federal, por meio do Prohap Comunidade, é fruto da I Caravana a Brasília, ocorrida durante o Governo Sarney, em 1988, quando são conquistados três projetos-piloto de 150 unidades para o estado de São Paulo: 50 para a Região Leste II, 50 para São Bernardo do Campo Associação Comunitária e 50 para Diadema - Associação de Construção Comunitária de Diadema.

\begin{abstract}
A Leste II passou as 50 unidades para a entidade de Diadema, que estava com um terreno denominado Buraco do Cazuza ${ }^{43}$. Depois de um ano da negociação em Brasilia, eles não cumpriram o prometido, então levamos quatro ônibus para a Caixa da Avenida Paulista e íamos ficar dois dias lá. No fim do primeiro dia, veio um telegrama da Matriz, liberando a verba e autorizando a construção em mutirão e autogestão, nos moldes dos mutirões da Fucvam do Uruguai ${ }^{44}$.
\end{abstract}

Esse empreendimento teve a parceria de uma assessoria técnica, Usina, e da Prefeitura de Diadema, e é considerado o primeiro mutirão vertical do Brasil, com 5 andares. Na primeira etapa, são construídas 100 unidades: 52 casas sobrepostas e 48 apartamentos (dois blocos de cinco andares) e na segunda etapa mais 180, entre casas sobrepostas e apartamentos.

Na Caravana de 1990, os movimentos conquistam mais um empreendimento, de 236 unidades, no Município de Santo André, com financiamento do FGTS, no marco de um programa federal denominado Plano de Ação Imediata para Habitação (Paih), na gestão do

\footnotetext{
${ }^{43}$ O nome do proprietário era Gazourzi e o povo apelidou-o de Cazuza.

44 Depoimento de Maria Aparecida Tijiwa, da Associação de Construção Comunitária de Diadema, 2012.
} 
presidente Fernando Collor. O empreendimento é coordenado pela Associação de Construção Comunitária de Santo André, assessorado pelo Centro de Apoio à Autogestão Popular (Caap) e conta com o apoio da Prefeitura do Município de Santo André, que se responsabiliza pela infraestrutura.

Devido a disputas judiciais sobre o terreno, a obra só é concluída em 1997, já na gestão de Fernando Henrique Cardoso. Na inauguração, comparecem diversos dirigentes da Caixa e o Secretário Nacional de Habitação. Segundo Leonardo Pessina, coordenador do Caap, "Este mutirão representou um marco na luta pela autogestão e pelo Sistema e Fundo Nacional de HIS, abrindo caminhos junto a autoridades e técnicos da Caixa"45.

Figura 18 - Mutirão Jd. Santo André - 2000

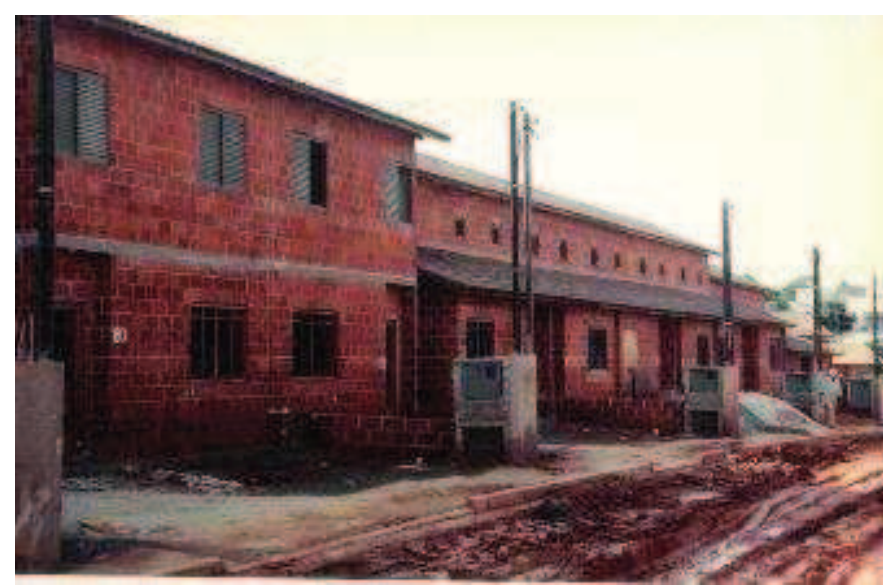

Fonte: CAAP

Os movimentos sociais seguem em sua ação de pressionar e propor, objetivando incorporar a proposta da autogestão em cada programa habitacional lançado pelo governo. Em 1999, com o lançamento do Programa de Arrendamento Residencial (PAR), a UNMP apresenta proposta de adaptação do programa para que "a própria associação seja o agente promotor do empreendimento, para desenvolver os projetos, efetuar a compra do imóvel, empreender a construção ou reforma e a gestão dos contratos" ${ }^{\prime 6}$.

\footnotetext{
${ }^{45}$ Depoimento dado à autora.

${ }^{46}$ UNMP. Ofício à Caixa Econômica Federal. 1999. Nesse ofício, a UNMP também apresenta proposta de fluxo para a produção habitacional em parceria com entidades, fruto de uma série de oficinas realizadas com movimentos e assessorias, que, apesar de nunca ter sido implementada, serviu de exercício para os processos seguintes de negociação.
} 
Figura 19 - Caravana da Moradia à Brasília - 1998

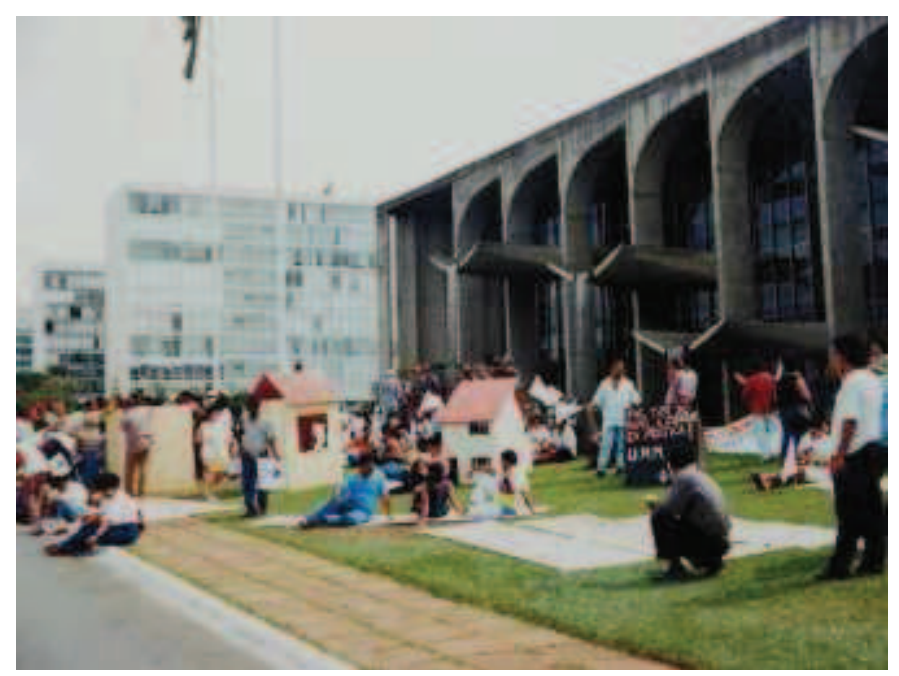

Fonte: Acervo UNMP

A proposta não é aceita pelo governo, e as entidades tornam-se apenas "organizadoras", com o papel praticamente clandestino de elaborar as propostas, porém os contratos continuam sendo feitos entre a Caixa e as construtoras, figurando a entidade apenas como testemunha e indicando a demanda dos empreendimentos.

O apoio às práticas autogestionárias, ao lado do apoio à indústria da construção, figura entre os princípios e as diretrizes do Projeto Moradia, do Instituto Cidadania (2000, p. 27), que define

Estímulo à gestão pública não estatal e à autogestão, com o apoio às iniciativas individuais ou coletivas da população para produzir ou melhorar sua moradia. Incentivo à formação de agentes promotores e financeiros não estatais, como cooperativas e associações comunitárias autogestionárias, na efetivação dos programas habitacionais.

Alem disso, o Projeto Moradia também defende a diversidade de agentes promotores, programas e projetos, citando, dentre outros, as cooperativas e associações e as práticas autogeridas.

Em 2003, com o início da gestão do presidente Lula e a criação do Ministério das Cidades (MCidades), os movimentos populares retomam as pautas gerais, como a criação da Conferência e do Conselho Nacional das Cidades, a aprovação do Fundo Nacional de Moradia Popular e a instituição das políticas setoriais articuladas, como saneamento, habitação e mobilidade, além de uma ação do governo federal para implementar o Estatuto 
da Cidade. Simultaneamente, retoma-se a pauta da autogestão, que é novamente reivindicada desde as primeiras negociações travadas com o Ministério:

\begin{abstract}
A UNMP defende a autogestão como uma maneira não só de construir casas, bairros ou equipamentos sociais, mas como uma forma de construção de poder popular. Ao controlar recursos públicos e processos, lutamos contra o clientelismo e a manipulação do poder público sobre a população e as organizações sociais. Construímos alternativas de gestão onde somos sujeitos de nossa história ${ }^{47}$.
\end{abstract}

Como não havia, no cenário imediato, a possibilidade de viabilizar recursos orçamentários para a criação de um novo programa, o movimento apresenta nova proposta de adaptação do Programa de Arrendamento Residencial (PAR) que incluía a modalidade de autogestão, retomando e ampliando a proposta de $1999^{48}$.

A proposta apresentada ao MCidades já continha a maior parte dos princípios a serem atendidos na mudança da política de habitação, como a destinação de subsídios para as famílias de baixa renda e a retirada de restrições de crédito para o acesso das famílias, recursos para assistência técnica, desburocratização e mais transparência nos procedimentos de aprovação dos projetos, destinação de terras públicas para HIS e o uso misto das edificações, para comércio ou equipamentos sociais. Algumas alterações foram feitas no PAR, mas não atenderam à proposta da autogestão, que efetivamente tinham natureza distinta dos princípios do programa.

Ainda em 2003, novas articulações aprovam propostas para a criação de programas autogestionários nas resoluções da 1a Conferência Nacional das Cidades, que define as diretrizes das políticas urbanas a serem implementadas pelo MCidades.

[...] Incentivar a participação de agentes promotores e financeiros e apoiar a formação de cooperativas e associações comunitárias de autogestão na implementação de políticas, programas e projetos de desenvolvimento urbano, habitação e gestão ambiental. [...] Financiamento de cooperativas, associações autogestionárias, mutirões, sindicatos, organizações não governamentais, sem fins lucrativos, com recursos onerosos e não onerosos (subsídio). (1aㅡ CONFERÊNCIA DAS CIDADES. Resoluções, 2003).

\footnotetext{
47 UNMP. Ofício ao Ministério das Cidades. abr. 2003.

48 Idem.
} 


\subsubsection{Programa Crédito Solidário}

As entidades continuam pressionando o governo para que crie um programa em parceria com os movimentos e que possibilite a autogestão. Ao final de 2003, o MCidades apresenta uma proposta, que prevê a utilização do Fundo de Desenvolvimento Social (FDS) para abrigar um programa autogestionário. O FDS foi criado em 1991, com recursos de aquisições compulsórias e voluntárias de cotas, por entidades financeiras, emitidas pelos Fundos de Aplicação Financeira (FAF), é gerido pelo Conselho Curador do FDS ${ }^{49}$ (CCFDS) e pelo resultado de suas aplicações. Trata-se de recurso oneroso, com patrimônio líquido significativo, que pôde dar melhores condições aos financiamentos.

Em abril de 2004, uma série de ocupações e manifestações simultâneas, em diversos estados, pressiona o governo federal para viabilizar a proposta. Após inúmeras negociações internas no governo entre o MCidades e a Caixa ${ }^{50}$ e negociações com os movimentos, o Programa Crédito Solidário (PCS) é aprovado pelo Conselho Curador do Fundo de Desenvolvimento Social ${ }^{51}$. Para os movimentos, o programa seria temporário, enquanto não se conquistava a aprovação do Fundo Nacional de Moradia Popular, ainda, naquele momento, sem consenso no governo e sem aprovação no Congresso Nacional.

Aprovado o programa, o MCidades divulga, ainda em 2004, uma sistemática de seleção de projetos para as entidades. Para isso, elas deveriam remeter uma proposta, contendo informações da entidade, da área a ser utilizada e do projeto preliminar 0 MCidades recebe 2.759 propostas e seleciona 684 em quase todo o País.

A partir daí, as entidades deveriam entregar os projetos, documentos do terreno e aprovações nas Gerências Regionais de Desenvolvimento Urbano (Gidurs) na Caixa. Nessa etapa, começam a surgir dificuldades para as entidades, já que o grau de exigência para os empreendimentos, por um lado, e os obstáculos encontrados inviabilizam a maioria das

\footnotetext{
${ }^{49}$ O CCFDS é composto por representantes do governo federal, do setor empresarial e financeiro e das centrais sindicais.

${ }^{50}$ A Caixa atua como agente operador do FDS, cuidando da aplicação e retorno dos recursos e como agente financeiro, gerindo a aplicação dos recursos em programas habitacionais.

51 O CCFDS é composto por representantes do governo federal e de entidades empresariais, e ligado aos setores financeiro e sindical.
} 
propostas selecionadas. Nos anos de 2005, 2006 e 2007, apenas 158 empreendimentos urbanos chegam à efetiva contratação.

Figura 20 - Mutirão Colinas da Oeste - PCS - São Paulo -SP - 2011

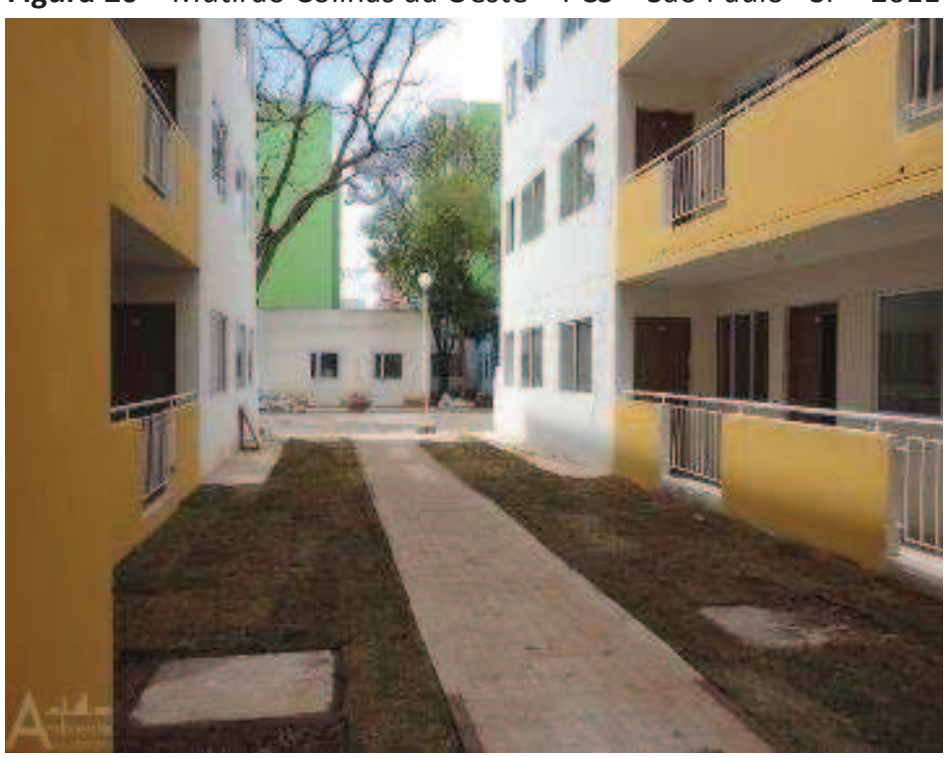

Fonte: Ambiente Assessoria

Figura 21 - Vale das Flores - PCS - São Paulo -SP - 2012

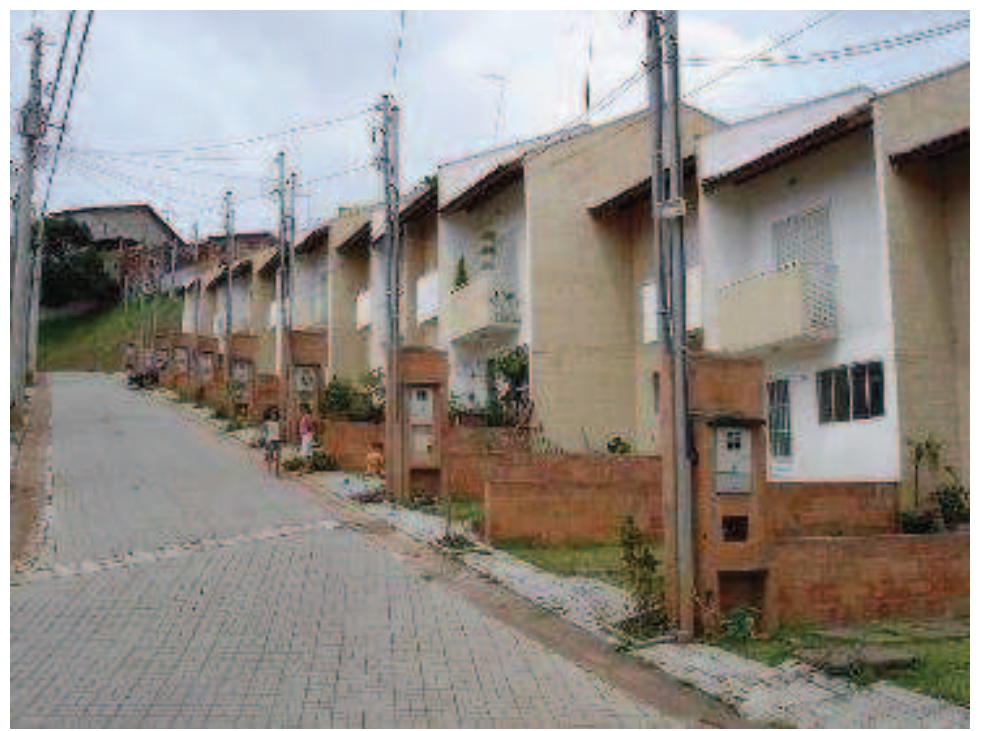

Fonte: Ambiente Assessoria 
Figura 22 - Residencial Maria Firmina - Paço do Lumiar-MA - 2009

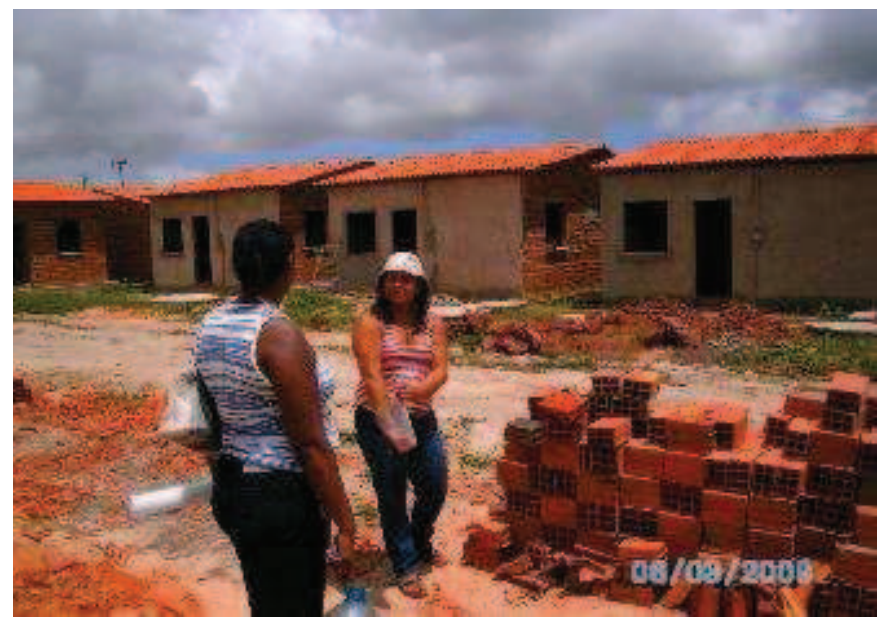

Fonte: Acervo UNMP

Moreira (2008, p.113) descreve essa questão e suas consequências para o programa:

O desenho do programa que atribuiu às associações uma capacidade de investimento inicial muito além do que parte delas poderia oferecer, foi formatado com base nos contratos de crédito imobiliário realizados tradicionalmente pela CEF junto às prefeituras e construtoras. Essa despesa inicial significativa teve que ser aportada pela associação ou como contrapartida pelas próprias famílias, sem que tivessem a garantia da efetivação do contrato. Condição que resultou na desistência de associações que não tiveram meios para dar continuidade ao desenvolvimento da proposta por falta de condições financeiras, técnicas e institucionais para cumprir com as exigências dessa primeira etapa.

Figura 23 - Trabalho em mutirão - PCS Mar Azul - Salvador-BA - 2008

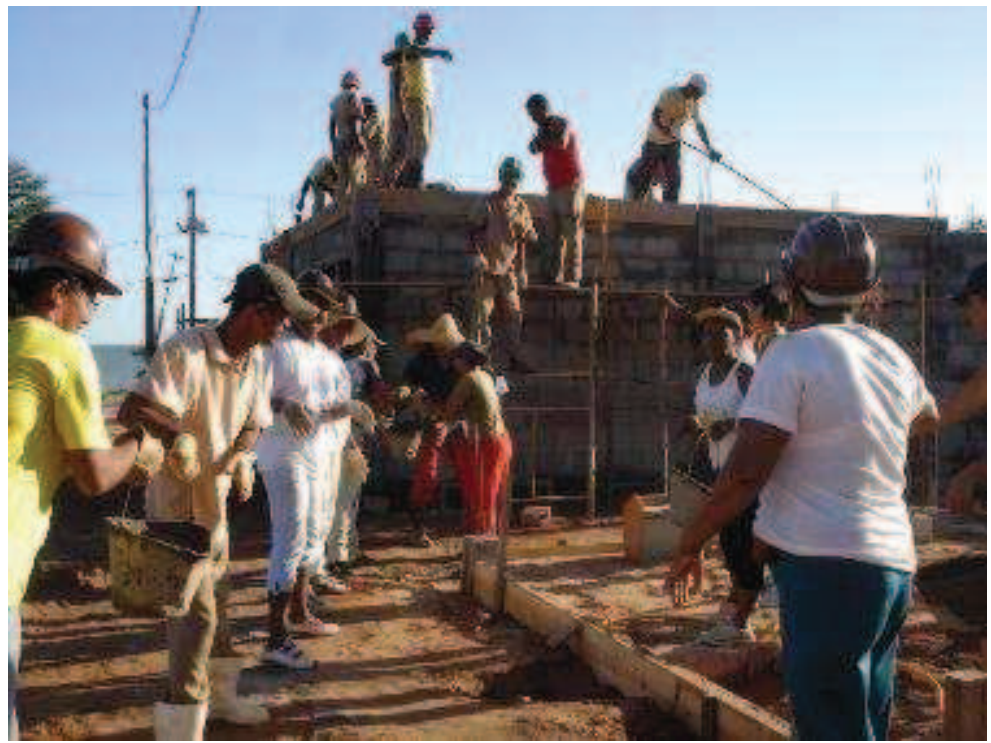

Fonte: UMP - BA 
O PCS é um programa de financiamento, com recursos onerosos e juros zero. Suas vantagens são os subsídios indiretos, que barateiam o custo do financiamento, mas que se insere na lógica financeira dos demais programas do SFH. O PCS, nesse sentido, é uma adaptação para atender às reivindicações dos movimentos, mas com uma série de limites.

Ao longo desse período, acontecem inúmeras manifestações, passeatas, acampamentos, ocupações e reuniões reivindicando a "desburocratização" do PCS. Sob essa palavra de ordem, os movimentos incluem diversas questões, desde mudanças nas condições de concessão de financiamento e requisitos para contratação, a mudanças de posturas, especialmente da Caixa, que dificultam a viabilização das propostas.

Já no final de 2004, a UNMP divulga documento que apontava os problemas encontrados para viabilizar o programa e questionava, por exemplo, a forma de financiamento, que, na realidade, era uma soma de financiamentos individuais e não um financiamento dado à cooperativa ou associação ${ }^{52}$. Alem disso, defendia a articulação entre governo federal, estados e municípios para viabilizar os empreendimentos.

No entanto, os dilemas do PCS continuavam, somando as dificuldades de contratação a novas questões que diziam respeito à execução e conclusão das obras. A partir das mudanças ocorridas tanto no MCidades $^{53}$, quanto na direção da Caixa ${ }^{54}$, os movimentos buscam ampliar seu espaço de interlocução, discutindo em reuniões conjuntas, mas também com a Secretaria Geral da Presidência da República, para incidir nos rumos e na implementação do programa.

Por ocasião da 3a Conferência das Cidades, ocorrida em novembro de 2007, o MCidades e a Caixa lançam uma série de medidas que alteram fundamentalmente a forma de financiamento do PCS. Essas mudanças são consolidadas na Resolução 121, de 9 de janeiro de 2008, e na Instrução Normativa 14, de 25 de março de 2008. As novas regras são chamadas de Programa Crédito Solidário 2.

\footnotetext{
52 UNMP. Carta de Pernambuco. 2004.

53 Em julho de 2005, o então ministro Olívio Dutra, do PT, é substituído por Márcio Fortes, do Partido Progressista (PP), da base aliada do governo e sem vínculo com a trajetória de luta da reforma urbana.

54 Em 2007, a Caixa cria a Gerência Nacional de Habitação de Interesse Social, que tem como principal finalidade a coordenação de programas habitacionais em parceria com associações e cooperativas.
} 
Durante o ano de 2008, um debate ocupa a pauta de negociações entre governo e movimentos de moradia: a revitalização do PCS ou a aposta no programa Produção Social da Moradia, com recursos do FNHIS. Com os recursos não onerosos do FDS se esgotando, o PCS estaria inviabilizado, a menos que houvesse um aporte de recursos orçamentários para subsidiá-lo.

Havia propostas, ainda, de negociação com os bancos detentores de cotas no FDS, para que parte dos recursos deixasse de ser oneroso, mas essa proposta nunca prosperou. Os movimentos, ao mesmo tempo em que defendiam que os recursos deveriam ser destinados ao FNHIS, seguiram negociando mudanças no PCS. O XI Encontro Nacional da UNMP pautava: "ampliar a destinação de recursos para o Programa de Produção Social da Moradia e propomos 500 milhões reais para o orçamento de 2009 e a ampliação dos recursos disponíveis no Programa Crédito Solidário" 55.

\subsubsection{Sistema Nacional de Habitação de Interesse Social e Programa Produção Social da Moradia}

Com a aprovação da Lei 11.124/2005, que cria o Sistema Nacional de Habitação de Interesse Social (SNHIS), os movimentos sociais concentram-se na proposição de um programa dentro do FNHIS, que substituiria o PCS. Os problemas, como já citado, iniciam-se com a composição de recursos do Fundo, restrita ao OGU, e às formas de repasse aos agentes promotores.

Ao mesmo tempo, uma análise jurídica da lei sancionada define que os recursos do FNHIS só poderiam ser destinados a entes públicos, excluindo as cooperativas e associações. Essa questão toma grande parte da agenda dos movimentos sociais, de 2006 a 2008, e dá início a um longo processo de pressão. Dentro do governo, havia posições divergentes. Os que se posicionavam contra o repasse direto às entidades e associações, alegavam que a

\footnotetext{
55 UNMP. Documento final do XI Encontro Nacional de Moradia Popular. Goiânia, jun. 2008.
} 
medida romperia a construção do SNHIS, que deveria articular as ações com estados e municípios e estes constituírem seus programas.

O impasse somente foi encerrado com a intervenção direta do Presidente da República, após diversas ocupações e manifestações dos movimentos populares, e implicou a alteração da Lei do SNHIS, com a aprovação de uma emenda ${ }^{56}$ apresentada à Medida Provisória $387 / 2007^{57}$, convertida na Lei $11.578 / 2007$, que admite o repasse de recursos diretamente às entidades.

O debate no Congresso Nacional foi acalorado, pois o Senado excluiu o artigo que permitia o repasse de recursos às entidades, alegando favorecimentos políticos e a possibilidade de corrupção que a medida poderia gerar. O projeto voltou à Câmara e também sofreu oposição, merecendo a defesa de diversos parlamentares, dentre eles o deputado Vicentinho (PT-SP):

\begin{abstract}
as associações e cooperativas habitacionais populares já são caracterizadas como agentes promotoras das ações do sistema, de acordo como art. 5o, inciso VII da citada lei. São agentes que acumularam experiências na produção social e sustentável limitação de qualidade, com um padrão digno, por meio de projetos autogestionários, participativos, utilização de tecnologias alternativas sustentáveis e implementação de projetos diferenciados, de acordo com a realidade dos diversos núcleos de famílias brasileiras. Nada mais justo que essas entidades tenham acesso aos recursos do Fundo Nacional de Habitação de Interesse Social para o desenvolvimento de suas atividades. A alteração da lei, com acréscimo do § 6o, como proposto pelo PLV, aprovado na Câmara dos Deputados, é de fundamental importância para aumentar, diversificar e qualificar a produção habitacional de interesse social do País. ${ }^{58}$
\end{abstract}

Com a alteração da lei, é criado o programa Produção Social da Moradia (PSM), a partir de uma série de propostas, apresentada pelos movimentos sociais e o FNRU e discutida em um grupo de trabalho criado no MCidades especificamente para esse fim. A

\footnotetext{
${ }^{56}$ Apresentada pelo deputado Zezéu Ribeiro, em articulação com o FNRU.

57 A MP incluía no Artigo 24-A, da Lei 11.124, o seguinte parágrafo: “§ 60 Os recursos do FNHIS também poderão, na forma do regulamento, ser aplicados por meio de repasse a entidades privadas sem fins lucrativos, cujos objetivos estejam em consonância com os do Fundo".

${ }^{58}$ Deputado Vicentinho, em sessão que finalmente aprovou a medida provisória. Disponível em:

<http://www.camara.gov.br/internet/sitaqweb/TextoHTML.asp?etapa=5\&nuSessao=319.1.53.0

\&nuQuarto $=47 \&$ nuOrador $=2 \&$ nulnsercao $=11 \&$ dt HorarioQuarto=10:32\&sgFaseSessao $=0 D$

\&Data=13/11/2007\&txApelido=VICENTINHO, PT-SP\&txFaseSessao=Ordem do Dia

\&txTipoSessao=Extraordinária - CD\&dtHoraQuarto=10:32\&txEtapa=>.
} 
Resolução 18 é aprovada em março de 2008 e o primeiro edital sai somente em outubro de 2008, com a seleção concluída em março de 2009.

Após a seleção, novos problemas aparecem, especialmente relacionados à sistemática de repasse dos recursos às entidades. Como se tratava de repasse de recursos do OGU, as entidades deveriam seguir o disposto nas portarias já citadas anteriormente. 0 governo recém implantava o Sistema de Convênios (Siconv) para acompanhar todas as etapas, da contratação à conclusão e prestação de contas dos repasses efetuados.

As entidades, que já haviam se organizado com a sistemática do PCS, se depararam com uma lógica completamente distinta e que se referia muito mais a estados e municípios do que a entidades sem fins lucrativos. Além disso, o Siconv ainda estava sendo ajustado e carecia de diversos aperfeiçoamentos. Como todo o processo é baseado na Lei de Licitações, induzia à contratação de empreitada global, pois, no caso de autogestão, cada compra, ou contratação de mão de obra, deveria ser antecedida de um processo licitatório, o que, na prática, o inviabilizaria.

Por fim, o FNHIS não poderia antecipar parcelas de recursos para as obras, o que é fundamental para a atuação de entidades que não possuem capital de giro.

Soma-se, a essa situação, o lançamento do programa MCMV, em março de 2009, que concorreu com o PSM. Além de contar com valores muito maiores para o financiamento das unidades, não possuía as regras de repasse do OGU, como se verá adiante. O lançamento do programa MCMV também mobiliza a ação do MCidades e da Caixa, deixando o PSM pouco atrativo às entidades. Prova disso é que, das 112 operações selecionadas em 2009 e 2010, apenas 20 efetivamente iniciaram suas obras ${ }^{59}$.

Ao lado do PSM, o Conselho Gestor do FNHIS amplia a ação de apoio à Assistência Técnica, que também passa a ser acessada por entidades e se destinava a garantir apoio técnico para elaboração de projetos e acompanhamento de obras de provisão habitacional. A ação visava atender ao disposto na Lei da Assistência Técnica ${ }^{60}$, outra agenda dos movimentos sociais e entidades profissionais.

\footnotetext{
${ }^{59}$ CAIXA. Operações PSM. 2011.

${ }^{60}$ Lei no 11.888, de 24 de dezembro de 2008
} 
Ao mesmo tempo, os movimentos também se dedicam a incluir a autogestão dentro das propostas do PlanHab. Em seu 11 Encontro Nacional, a UNMP afirma, em seu documento final:

\begin{abstract}
A produção social deve fazer parte do Sistema Nacional de Habitação, como uma de suas expressões. Deve ser reconhecida, apoiada e promovida por ações do poder público em nível nacional, estadual e municipal. A possibilidade das cooperativas e associações em acessar recursos dos fundos nacional, estaduais e municipais, promovendo ações habitacionais, deve estar prevista em todos os programas habitacionais como uma modalidade e concepção de gestão, nos convênios e contratações, valorizando a organização comunitária e o saber popular. (UNMP, 2008 - Relatório do Encontro Nacional).
\end{abstract}

O PlanHab, que foi concluído em 2009, reconhece a autogestão dentro do leque de propostas para a produção habitacional, e é uma das estratégias adotadas e um dos itens das linhas programáticas a serem financiados pelo governo federal, por suas diversas fontes de recursos $^{61}$. Essa posição é reafirmada por Bonduki (2008, p.37), coordenador da elaboração do PlanHab, para quem

Depois de um amplo período em que a autogestão foi considerada uma experiência a ser testada, chegou o momento de passar a ser parte do equacionamento do problema habitacional brasileiro, participando, em conjunto com outras formas de promoção, do grande desafio de colaborar com a produção massiva de habitação.

\title{
2.2.3 Minha Casa Minha Vida -Entidades
}

No final de 2008 e início de 2009, os movimentos e o FNRU realizam diversas atividades de mobilização, como a Jornada de Lutas pela Reforma Urbana, em novembro de 2008, com ocupações e manifestações em diversos estados. Dessas mobilizações, são reabertos alguns canais de negociação, que culminam em uma audiência com o Presidente da República e outra com a então ministra da Casa Civil, Dilma Roussef, no início de 2009, quando os movimentos apresentam propostas para serem incluídas ao "pacote habitacional" e reivindicam que parte das 1 milhão de casas fosse construída por autogestão.

\footnotetext{
${ }^{61}$ MINISTÉRIO DAS CIDADES. Plano Nacional de Habitação. 2009.
} 
Além disso, os movimentos elaboram um conjunto de propostas para o novo programa, discutido em reuniões com o MCidades e a Caixa. Essas propostas tratam de melhorias no financiamento coletivo, viabilização de terrenos, apoio à elaboração dos projetos, ampliação de recursos para a gestão e o trabalho social, apoio a tecnologias inovadoras e sustentáveis, uso misto dos imóveis, criação de regras claras e simplificadas dos programas e redução da burocracia na análise e contratação.

Desse processo de negociação, surge o programa MCMV-E que destina recursos orçamentários para o FDS. Parte de suas regras é incorporada do antigo PCS e parte equiparada ao Programa MCMV destinado às construtoras. Para o MCMV-E, são destinados $\mathrm{R} \$ 500$ milhões, em sua primeira etapa, e estabelecida uma meta de 60 mil unidades para a segunda etapa. Posteriormente, em audiência com a Presidenta Dilma Roussef, em 2012, a meta é ampliada para 200 mil unidades.

Apesar da conquista de um programa autogestionário dentro do pacote habitacional, dentre os questionamentos feitos pelos movimentos, estava justamente a concepção do programa que priorizava a produção privada da habitação e, ainda, a excessiva burocracia para as entidades: enquanto os programas destinados às construtoras são rapidamente regulamentados e revisados, o MCMV-E sofre com prazos estendidos para a edição de resoluções e instruções normativas e a falta de prioridade nas análises e aprovações.

Parte das propostas de formatação apresentadas pelos movimentos é incorporada ao MCMV-E, em sua versão inicial e nas revisões seguintes. Há que destacar a proposta de Compra Antecipada que será detalhada adiante. No entanto, o MCMV-E ainda tem as características de um programa destinado às construtoras, "adaptado" aos movimentos, em diversos aspectos.

Além disso, apesar de contar com recursos orçamentários, o programa é tratado como um "financiamento habitacional", ainda que com condições bastante favoráveis, o que impacta na concepção da concessão dos créditos e dos empreendimentos, como se verá a seguir. De 2009 a 2012, são realizadas diversas manifestações que reivindicam melhorias no programa e sua alteração. 
Ainda em 2009, fruto da reivindicação dos movimentos populares do meio rural, é criado o Programa Nacional de Habitação Rural (PNHR) ${ }^{62}$. O programa também tem como protagonista as entidades sociais, especialmente as cooperativas habitacionais da agricultura familiar, associações e sindicatos de trabalhadores rurais. O programa tem regras específicas para o meio rural e baseia-se na experiência das cooperativas com os programas Crédito Solidário, Programa de Subsídio Habitacional (PSH) e Operações Coletivas.

Figuras 24, 25 e 26 - Moradias rurais produzidas pelo PNHR - 2011 e 2012
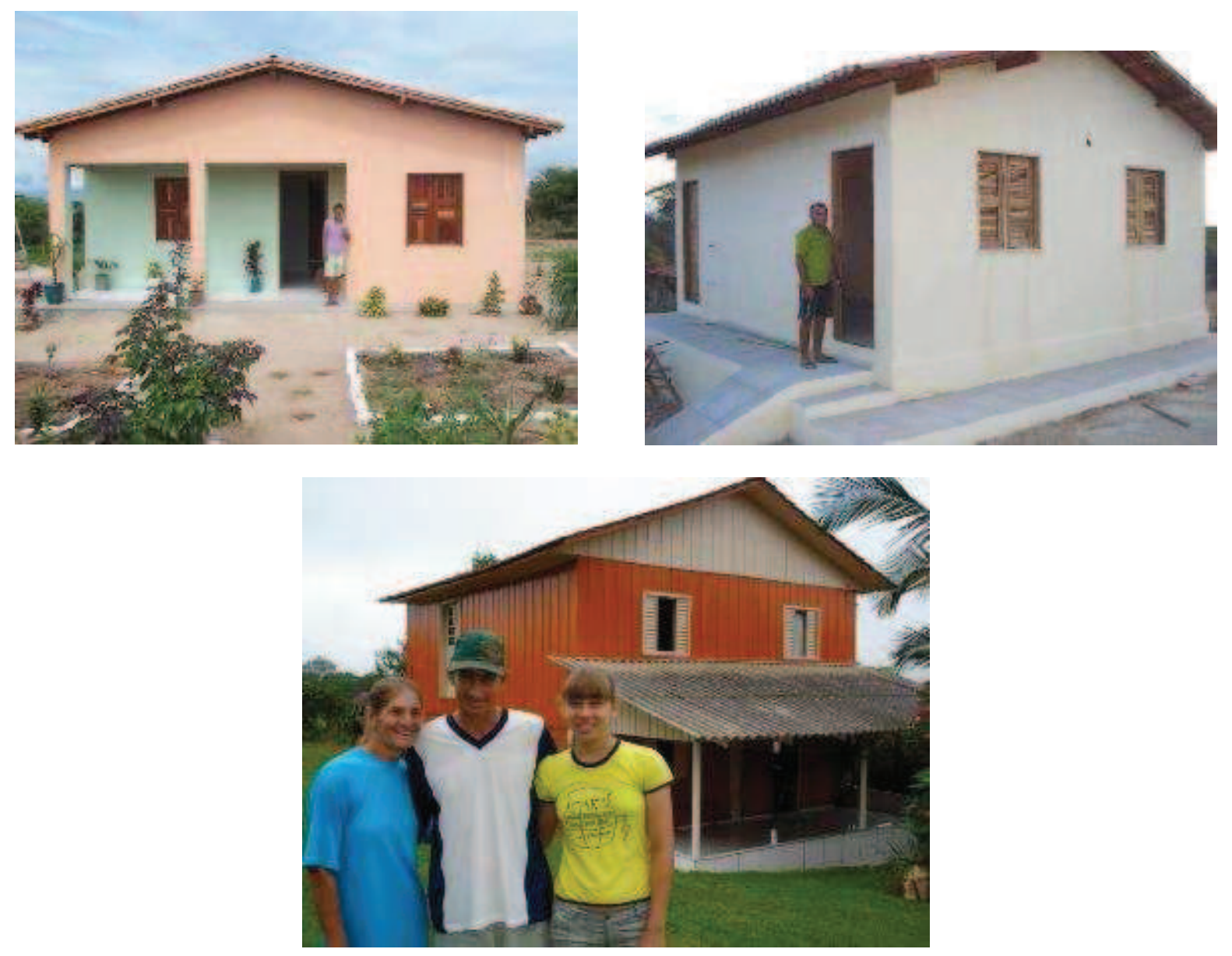

Fonte: Cooperhaf

Ainda assim, no final de 2011, decorrente de denúncias feitas em outras áreas do governo, surge um questionamento sobre os repasses de recursos públicos para entidades sem fins lucrativos. O governo reage, suspende o repasse dos recursos e realiza verificações nos projetos contratados. Os movimentos criticam a criminalização das entidades sociais,

\footnotetext{
62 Portaria Interministerial 484, de 28 de setembro de 2009.
} 
considerando que é inaceitável, inexplicável e arbitrária a suspensão destes repasses, para Produção Social da Moradia, uma vez que os critérios de seleção, contratação e desenvolvimentos dos projetos são amplamente transparentes e obedecem tanto a lógica quanto o rito processual dos sistemas governamentais e jurídicos, com efetivo controle social ${ }^{63}$.

Ao final do período de suspensão, todos os empreendimentos do MCMV-E e do PNHR são aprovados e retomados, mas resta clara a fragilidade do tema dentro da política habitacional.

Figura 27 - Empreendimento Mangabeiras - MCMV-Entidades - Feira de Santana-BA - 2012

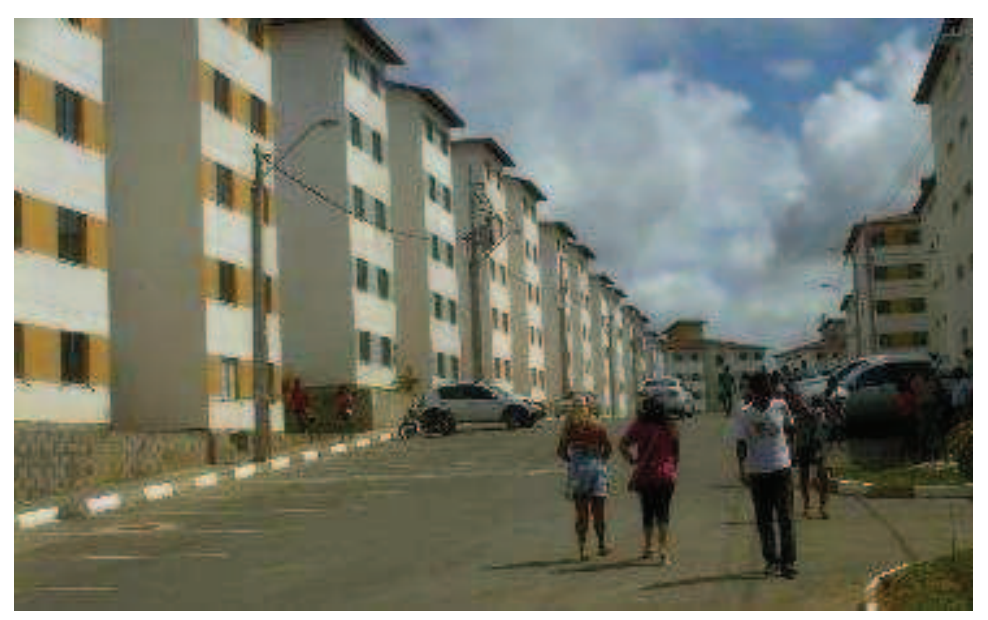

Fonte: UMP-BA

Figura 28- Residencial Lagoa Quente -Caldas Novas/GO - 2012

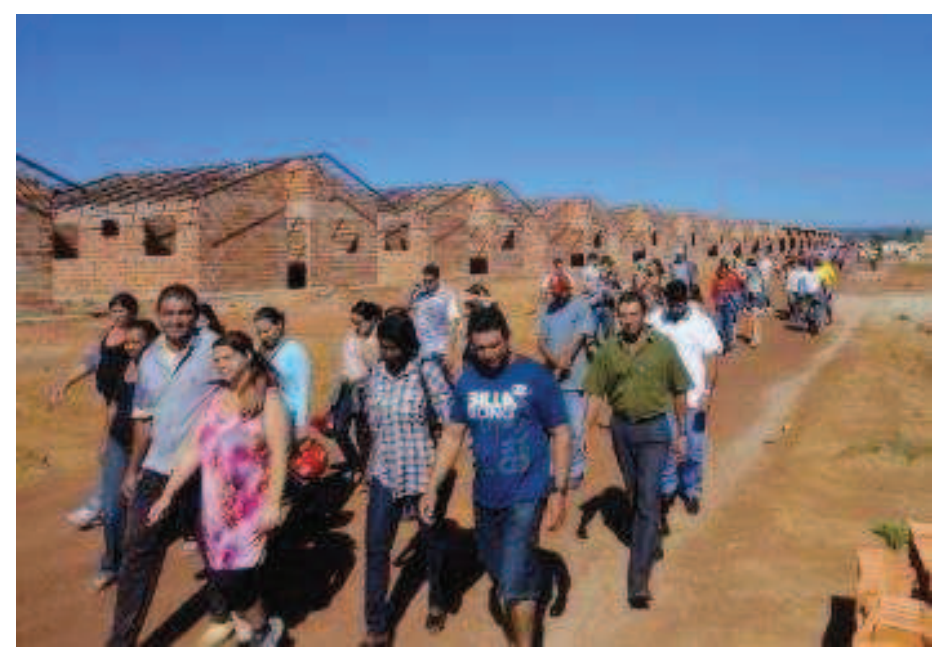

Fonte: Acervo UNMP

63 UNMP. Carta ao povo brasileiro. XII ENCONTRO NACIONAL DE MORADIA POPULAR. Belo Horizonte, 2011. 


\subsection{Características dos programas em parceria com entidades}

As diferenças mais marcantes entre o PCS e a MCMV-E estão na forma de financiamento de cada um deles. Apesar de ambos estarem abrigados no FDS, a origem de seus recursos e a forma de concessão de financiamento são totalmente distintas. O PCS tem como recurso os próprios depósitos do FDS, que são onerosos, e o MCMV-E é baseado em recursos do OGU, repassados ao FDS, pela Lei 11.977/2009.

\subsubsection{Formas de acesso ao financiamento habitacional}

O PCS é um programa de financiamento, em que o beneficiário retorna integralmente o valor de investimento, em até 20 anos, sem taxa de juros, o que o torna uma exceção no panorama dos demais financiamentos habitacionais da época, podendo ser tomado por famílias de menor renda em relação, por exemplo, àquelas atendidas pelo FGTS.

O MCMV, na faixa até três salários-mínimos, tem uma equação financeira distinta, tanto em sua versão para entidades como naquela destinada à operação por construtoras (FAR). Possui recursos orçamentários e o valor financiado independe da capacidade de pagamento da família beneficiária, fixando as mensalidades em $10 \%$ da renda família ${ }^{64}$ e prazo de pagamento de 10 anos. Os tetos dos valores de financiamento são fixados de acordo com os estados e o porte dos municípios.

Com essa equação, adota-se o subsídio parcial bastante significativo, como princípio do atendimento às necessidades habitacionais das famílias de mais baixa renda. Essa proposta sempre fez parte da agenda dos movimentos de moradia, que entendem que o valor de financiamento não deve estar atrelado à capacidade de pagamento, mas à necessidade habitacional. A UNMP, em 2007, afirmava que

A falta de uma forte política de subsídio, recursos massivos para as regiões metropolitanas, integração das políticas setoriais, programas que fortaleçam a autogestão, aliada ao clientelismo e a burocracia excessiva dos programas

\footnotetext{
64 O Decreto 7.795, de 24 de agosto de 2012, baixa as prestações para 5\% da renda, aumentando ainda mais o subsídio do programa.
} 
habitacionais têm provocado um fenômeno curioso: mesmo com o governo produzindo moradias, o déficit habitacional só aumenta e se concentra cada vez mais, entre os mais pobres ${ }^{65}$.

Outra inovação trazida pelo $\mathrm{MCMV}$, que já havia sido alvo de inúmeras propostas apresentadas pelos movimentos, foi a exclusão da análise cadastral dos beneficiários. Inúmeras famílias não podiam ser atendidas no PCS, por terem seus nomes inscritos no Sistema de Proteção ao Crédito (SPC) ou no Serasa.

Tabela 3 - Síntese das regras de financiamento

\begin{tabular}{|c|c|c|c|c|}
\hline & PCS 1 & PCS 2 & MCMV-E 1 & MCMV-E 2 \\
\hline Valor do encargo mensal & VF/240 + seguro & $V F / 240$ & $\begin{array}{l}\text { De } R \$ 50,00 \text { a } \\
R \$ 135,00\end{array}$ & $\begin{array}{l}\text { De } R \$ 25,00 \text { a } \\
R \$ 80,00\end{array}$ \\
\hline Subsídio direto & Não há & Não há & Até $90 \%$ do VF & Até $95 \%$ do VF \\
\hline Prazo de amortização & Até 20 anos & Até 20 anos & 10 anos & 10 anos \\
\hline Taxa de juros & $0 \%$ & $0 \%$ & $0 \%$ & $0 \%$ \\
\hline Atualização monetária & $\operatorname{Sim}$ & Sim & Sim & Sim \\
\hline Encargos pagos durante a obra & $\begin{array}{l}\text { Atualização } \\
\text { monetária + } \\
\text { seguro }\end{array}$ & Não há & Não há & Não há \\
\hline Seguro & $\begin{array}{l}\text { Pagos pelo } \\
\text { beneficiário }\end{array}$ & $\begin{array}{l}\text { Pagos pelo } \\
\text { FDS }\end{array}$ & Não há & Não há \\
\hline $\begin{array}{l}\text { Análise de capacidade de } \\
\text { endividamento }\end{array}$ & $\operatorname{Sim}$ & $\operatorname{Sim}$ & Não & Não \\
\hline Renda atendida & $\begin{array}{l}\text { De } 1 \text { a } 3 \text { SM } \\
\text { Até } 20 \% \text { de } 3 \text { a } 5 \\
\text { SM }\end{array}$ & $\begin{array}{l}\text { De } 1 \text { a } 3 \text { SM } \\
\text { Até } 20 \% \text { de } 3 \\
\text { a } 5 \text { SM }\end{array}$ & $\begin{array}{l}\text { De } 0 \text { a } \mathrm{R} \$ \\
1395,00 *\end{array}$ & $\begin{array}{l}\text { De } 0 \text { a } R \$ \\
1600,00^{*}\end{array}$ \\
\hline Análise cadastral (SPC/Serasa) & Sim & Sim & Não & Não \\
\hline Análise Cadmut/Cadin & $\operatorname{Sim}$ & $\operatorname{Sim}$ & $\operatorname{Sim}$ & Sim \\
\hline Desconto por adimplência & Não há & $5 \%$ & Não há & Não há \\
\hline
\end{tabular}

65 UNMP. Carta aberta em defesa da moradia e da reforma urbana. abril de 2007. 
* O valor de $\mathrm{R} \$ 1.395,00$ correspondia a 3 salários-mínimos (SM), na ocasião de lançamento do programa. As atualizações do salário-mínimo não indexaram a faixa de renda do programa, que perdeu essa correspondência.

No entanto, no entendimento de parte dos movimentos de moradia, esse modelo de financiamento ainda não atende a uma verdadeira política autogestionária, pois os financiamentos são individuais, tornando o empreendimento uma soma de financiamentos. A proposta defendida pelo movimento é que o financiamento seja coletivo, destinado ao grupo como um todo, podendo ou não ser individualizado, ao final do processo.

Esse quadro vem sendo parcialmente modificado, com a aprovação, pelo CCFDS, de modalidades destinadas ao financiamento às entidades e não diretamente às famílias. Visto inicialmente com desconfiança pelo governo, o modelo começa timidamente, em 2010, e toma força em 2012, com propostas de empreendimentos sendo apresentadas, e melhor regulamentação. A UNMP considera que as "mudanças reconhecem o protagonismo das entidades populares e fortalecem a autogestão" ${ }^{66}$. No entanto, as unidades ainda devem ser individualizadas ao final da obra e o retorno do financiamento será individual.

\subsubsection{Acesso a terreno para os programas}

Tanto o PCS quanto o MCMV-E podem financiar a aquisição de terrenos para construção, assim como aceitam terrenos doados ou cedidos pelo poder público ou adquiridos pelo grupo de famílias beneficiárias. Como o financiamento é viabilizado diretamente com o governo federal, pelas entidades, nem sempre há o apoio do poder local. Nesses casos, cabe à entidade disputar, com agentes privados, o mercado de terras urbanas viáveis para habitação. É importante relembrar que, nas anteriores experiências locais de autogestão, em geral, cabia ao Poder Público promover a obtenção e disponibilização da terra urbanizável.

\footnotetext{
${ }^{66}$ UNMP. O que muda com a nova resolução do Ministério das Cidades no programa Minha Casa Minha Vida Entidades. 2012.
} 
Para serem utilizados no programa, os terrenos devem ter a regularidade previamente atestada, nos âmbitos da propriedade, do parcelamento, do registro e da edificação a ser construída, diferindo da prática de boa parte dos programas públicos de habitação social desenvolvido historicamente. Essa exigência, por um lado, garante ao beneficiário a escritura do imóvel ao final do processo, mas está muito distante da realidade das terras urbanas disponíveis e acessíveis e dos processos de licenciamento nos órgãos públicos.

Essa realidade, desenhada no PCS, pouco se altera, no MCMV-E, apesar de ser questão contida nas críticas dos movimentos de moradia. No processo de negociação que leva à criação do $M C M V-E$, em reuniões com o Presidente Lula e a então ministra da Casa Civil, Dilma Rousseff, as entidades apresentam a proposta do que veio a ser chamada de Modalidade Aquisição de Terreno e Projetos, que ficou conhecida como Compra Antecipada.

A exigência de legalização prévia dos empreendimentos coloca o movimento em contato com um ator pouco afeito ao regime democrático: o Cartório de Registro de Imóveis. Os cartórios são verdadeiras empresas familiares de prestação de serviços públicos que, na tradição privatista brasileira, incorporaram características de forte e excessivo apego ao formalismo e à defesa incondicional de um modelo tradicional, individualista e descomprometido com a função social da propriedade. As alterações recentes na forma de delegação pública desse serviço não produziram, via de regra, alteração nesse modelo.

Os movimentos atuam fortemente durante o processo de construção da legislação do programa MCMV para garantir a gratuidade dos serviços registrais e a desburocratização dos procedimentos de registro e averbação dos títulos da regularização fundiária de interesse social e dos novos empreendimentos habitacionais populares. A lei do MCMV incorpora essa reivindicação, ao estabelecer que:

Art. 43. Os emolumentos referentes à escritura pública, quando esta for exigida, ao registro da alienação de imóvel e de correspondentes garantias reais e aos demais atos relativos ao imóvel residencial adquirido ou financiado no âmbito do PMCMV serão reduzidos em:

I - 75\% (setenta e cinco por cento) para os imóveis residenciais adquiridos do FAR e do FDS; 67

\footnotetext{
${ }^{67}$ Incluído pela Lei 12.424, de 2011.
} 
No entanto, os cartórios, seja usando seu arsenal jurídico para propor ações de inconstitucionalidade contra a lei do programa, ou mesmo formulando exigências técnicas descabidas nos pedidos que lhes são submetidos, têm obrigado o movimento a buscar apoio no Judiciário ou a pressionar por alterações constantes nas regras jurídicas do programa.

A questão da terra e sua regularização tem sido um dos maiores gargalos do programa, o que será aprofundado no Capítulo 4.

\subsubsection{Gestão da produção habitacional}

Na sua criação, o PCS admitiu três regimes de produção das moradias:

a) autoconstrução, pelos próprios beneficiários; b) autoajuda ou mutirão; ou c) administração direta, com contratação de profissionais ou empresas para execução de serviços que demandem maior especialização ${ }^{68}$.

No MCMV-E, admite-se ainda o regime "empreitada global". A opção pelo regime de construção deve ficar a critério dos beneficiários finais, mas, no MCMV-E, para a construção de empreendimentos verticalizados, exige-se a experiência prévia da entidade ou de sua assistência técnica. Ainda no caso de adoção de regime diferente da empreitada global, há um desconto de $8 \%$ no valor de teto do financiamento. Essas novas regras demonstram a nítida indução do governo para que adote a construção por empresas privadas, em detrimento de práticas autogestionárias.

As entidades que mantinham a autogestão em sua concepção política e organizacional, tiveram que se adaptar aos regimes estabelecidos. De modo geral, optaram pela "administração direta", com mutirão parcial. Nesse regime, a entidade contrata uma assessoria técnica multidisciplinar, que elabora o projeto e acompanha a execução das obras, além de formar um grupo gestor para as tarefas administrativas, a compra de materiais e contratação de trabalhadores e/ou serviços. As etapas das obras são contratadas uma a uma, de acordo com a sua complexidade, com prestadores de serviços diversos.

\footnotetext{
68 Instrução Normativa n. 39, de 28 de dezembro de 2005.
} 
Nessa modalidade, não há uma construtora responsável por toda a obra. No MCMV 2, criase o regime Autogestão, que ainda carece de melhor definição.

As famílias participam da gestão do empreendimento em assembleias, comissões de obra e trabalho mutirante. Em todos os empreendimentos, devem ser eleitas duas comissões, a Comissão de Acompanhamento de Obras (CAO) e a Comissão de Representantes do Empreendimento (CRE). Cada uma é formada, no mínimo, por um representante da entidade e dois representantes dos beneficiários e devem ser distintos entre si. A CAO tem a competência de coordenar a obra e, a CRE, de gerenciar os recursos do FDS.

Como as entidades não possuem capital de giro, nos regimes distintos da empreitada global, é aprovada a liberação antecipada de cada uma das parcelas de obra; somente após a execução e correspondente verificação da etapa executada, a Caixa libera a parcela seguinte.

Esse modelo de gestão ainda sofre bastante discriminação e não é totalmente incorporado pelo programa. Os agentes públicos ainda questionam a capacidade das famílias para o gerenciamento, a experiência da entidade e da assistência técnica, principalmente em relação aos riscos de execução e conclusão do empreendimento. Além das regras formais, antes descritas, há pressão dos técnicos governamentais para a contratação de empresas que executem a totalidade do empreendimento. Essa posição é rejeitada pela UNMP, que propõe:

\footnotetext{
- Priorizar as modalidades de autogestão e administração direta que representam a dimensão comunitária do programa;

- Apresentar os princípios da autogestão e do cooperativismo e fortalecê-los junto aos técnicos do poder público, sobretudo os que direta ou indiretamente lidam com o MCMV-Entidades, de modo que a produção de HIS por autogestão seja vista como um espaço avançado da política pública (e não o contrário), inclusive para colaborar na melhoria da qualidade dos projetos realizados por construtoras. ${ }^{69}$
}

Os movimentos têm empreendido, ainda que com precários recursos, atividades de capacitação e intercâmbio, a fim de difundir a proposta autogestionária e reivindicaram do governo que também o fizesse. Em maio de 2012, a Caixa realizou um Seminário Nacional com a participação de representantes de movimentos de moradia de todo o País, de

\footnotetext{
69 UNMP. Propostas da UNMP para o Minha Casa Minha Vida 2. 2011.
} 
funcionários responsáveis pelo programa de todas as Gidur, da Caixa Matriz e do MCidades. No seminário, foi apresentado um conjunto de mais de 200 propostas, algumas delas incorporadas nas resoluções seguintes e nos procedimentos internos do programa.

Se, em 1992, Bonduki (p. 162) afirmava que

Felizmente, nenhum burocrata está propondo ainda padronizar e regulamentar os movimentos urbanos - como foi feito com os sindicatos (...) - obrigando-os a ser uma entidade diferente daquilo que seus membros desejam.

em 2012 vê-se que os programas e suas normativas se tornam cada vez mais regulados e buscam uma padronização na forma de organizar os movimentos e suas ações. Para acessar os recursos, as entidades precisam seguir um roteiro formal, que muitas vezes não traduz o processo político de organização interna, exigindo, inclusive, mudanças de estatutos sociais, valorizando o formal em detrimento da participação coletiva.

Paralelamente, é observado um processo oposto, empreendido por algumas entidades. É a empreitada global travestida de administração direta, em que a proposta é toda formatada por uma construtora - sem a participação das famílias beneficiárias - que é apresentada por uma entidade habilitada no programa. Além disso, a entidade indica a proposta como "administração direta", obtendo com isso a antecipação de parcela - o que não ocorria na modalidade empreitada global - e dispensa a avaliação de risco da construtora. Essa tem sido uma distorção do programa, qualificada como "barriga de aluguel", por representantes do MCidades, e que toma o lugar de iniciativas efetivamente gestadas pela organização comunitária.

\subsubsection{Luta contra a burocracia estatal}

Além das questões gerais relacionadas com a formulação e execução da política habitacional do governo federal, as entidades do movimento popular também incluíram em sua pauta de reivindicações a necessidade de superar os entraves burocráticos que dificultam, ou mesmo impedem, a contratação e boa execução dos projetos habitacionais autogestionários. Um ano após o lançamento do programa MCMV, a UNMP denunciava: 
Desde que o Programa Minha Casa Minha Vida Entidades foi aprovado, as Associações e Cooperativas têm encontrado enormes dificuldades e inúmeros obstáculos para avançar nesta modalidade de Produção de Moradia Popular. A cada passo dado aparece uma dificuldade ou uma nova exigência, dificultando o acesso aos recursos de forma ágil e sem burocracia, impossibilitando, na prática, que a parceria para construção de moradia popular com famílias de renda até três salários-mínimos saia do papel $^{70}$.

A burocracia governamental é estreante nas relações com grupos organizados de origem popular e, entre interpretações excessivamente conservadoras da legislação, multiplicação de procedimentos internos pouco transparentes, e adoção de encargos que, aos movimentos, pesam demasiadamente, impõe a necessidade de se dedicarem a uma agenda que exige especialização das lideranças, capacidade técnica dos agentes técnicos e disposição em mobilizar-se, por parte da base social.

O MCMV-E está assentado em legislação (leis, decretos, resoluções, instruções normativas e manuais operacionais) que pouco incorporou das regulamentações anteriores dos programas autogestionários. Isso, aliado ao fato de que a estrutura operacional é pulverizada e assimétrica, gera pontos de conflito permanentes.

Reunindo questões que dizem respeito a problemas de interpretação da legislação, ausência de regulamentação, ou mesmo descumprimento de aspectos legais que se relacionam com os projetos, os movimentos passam a pressionar o governo para aperfeiçoar o programa.

São debates, por exemplo, sobre quais elementos técnicos devem ser exigidos da entidade organizadora para que uma proposta de compra de terreno possa ser aceita como apta; sobre a obrigatoriedade do registro da incorporação imobiliária no Cartório de Registro de Imóveis anteriormente à conclusão da obra; sobre a remuneração do trabalho social antes do início da obra, entre outros temas.

Em documento recente, são relacionadas como demandas dos movimentos, entre outras:

Estruturação da Gidur com a ampliação da equipe de análise e com perfil para se relacionar com os movimentos sociais; Imediata contratação dos projetos de compra antecipada protocolados e que já possuem parecer técnico da assessoria das entidades ou projeto aprovado/Suspensão da exigência da ART ou RRT de

\footnotetext{
70 UNMP. Manifesto Minha Casa, Minha Vida: Tá na hora de sair do papel. abr. 2010.
} 
execução para as assessorias técnicas nos projetos de autogestão (administração direta)/ Rapidez na liberação das parcelas dos projetos e obras em andamento (no máximo 30 dias)/Abertura das "Caixas-Pretas" (manuais internos da Caixa) para que os critérios de análise dos projetos sejam conhecidos por todos/ Participação dos técnicos da Caixa no acompanhamento nas negociações com os proprietários e nos processos de licenciamento junto aos órgãos públicos/ Participação dos técnicos operacionais e dos advogados nas reuniões de acompanhamento dos projetos/Antecipação das liberações de recursos para a elaboração do projeto social e acompanhamento das famílias na etapa de projeto ${ }^{71}$.

A discussão sobre temas estritamente relacionados com o cotidiano dos projetos, de um lado, permite que as lideranças dos movimentos se apropriem de aspectos técnicos dos projetos que impedem o avanço do programa autogestionário. Entretanto, também consome energias que poderiam estar direcionadas para aspectos estratégicos. Administrar os dilemas burocráticos cotidianos e continuar a reivindicar os avanços políticos necessários às políticas de desenvolvimento urbano são desafios a serem enfrentados na atual etapa das lutas populares.

\subsubsection{O papel da Assessoria técnica}

A assessoria técnica dos projetos autogestionários resulta da aliança política entre profissionais comprometidos com a produção social da cidade e os movimentos de moradia vinculados com a agenda da transformação social ${ }^{72}$. A relação entidade/assessoria técnica constitui, historicamente, a essência da proposta autogestionária. Isso permite conceber a moradia não apenas como uma mercadoria a ser consumida, mas como uma forma de incluir os cidadãos nos processos econômico, social e político.

No caso dos programas autogestionários federais, entretanto, a questão ainda não está corretamente posicionada. Desde o surgimento do programa Crédito Solidário, é

\footnotetext{
${ }^{71}$ UMM/SP. Carta aberta à população. Distribuída em 17 de abril de 2012, durante protesto na agência matriz da Caixa Econômica Federal.

72 ARANTES, Pedro Fiori. Assessoria técnica para autogestão. SEMINÁRIO PRÁTICAS DE MORAR. Ciclo Internacional de Debates - ONG Cidade. Porto Alegre, Faculdade de Arquitetura/UFRGS, 9.12.2011. Disponível em: <www.youtube/watch?v=RFUaMisa90Y\&feature=relmfu>.
} 
inegável que evoluiu, mas ainda se coloca como uma das insuficiências graves que os programas precisam corrigir.

A regra inicial do Crédito Solidário não detalha o que seria o conteúdo do trabalho de assessoria técnica. E, país afora, a concepção pode variar da simples assistência técnica que elabora o projeto e coordena a produção das unidades habitacionais até a construção coletiva da proposta de ação, da escolha dos terrenos, da elaboração dos projetos, da capacitação das famílias para o processo autogestionário, das negociações com o poder público e para a execução da obra de maneira compartilhada.

A atual regulação do MCMV-E considera a assessoria técnica como participante necessário do processo e inclusive detalha quais ações são remuneradas com os recursos do programa. Na maioria dos casos, todo o trabalho anterior à contratação do empreendimento é feito de forma não remunerada ou arcada pela cotização das próprias famílias, de modo que, além das dificuldades reais para sua efetivação, todo o risco corre por conta desses dois agentes e não da política pública.

No caso da modalidade compra antecipada, inclusive, está prevista a possibilidade de liberação de recursos na etapa de elaboração dos projetos, algo não contemplado nas demais modalidades, mas fundamental para possibilitar as condições materiais para o trabalho dos profissionais dedicados a esse modo de produzir habitação. Recentemente, também foi aprovada uma modalidade para apoio à elaboração de projetos destinados a terrenos doados ou cedidos pelo poder público ou de propriedade da entidade.

Outro aspecto a ser considerado é a abrangência do trabalho das assessorias técnica. As implicações práticas da exigência de legalização dos empreendimentos levam à necessidade de contar com advogados que se aproximem das formas de atuação dos movimentos populares e adotem posturas propositivas para superar os gargalos jurídicos a que os projetos estão submetidos. Também, cada vez mais se percebe a necessidade de apoio para a administração e gestão financeira que é de responsabilidade das entidades. As novas redes de articulações políticas que se fortalecem, como a economia solidária, são possibilidades que podem ampliar a qualidade de gestão dos empreendimentos.

O documento final do último encontro da UNMP indica a urgência da criação de uma 
servidores da Caixa, de promover assessoria multidisciplinar, envolvendo diversas áreas: social, arquitetura, engenharia, jurídica, administrativa financeira, comunicação, e da necessidade de criação de uma escola nacional de formação política para lideranças do movimento de moradia (multiplicadores) e assessores (formação política e formação em autogestão)" ${ }^{73}$.

\subsubsection{A importância do trabalho social}

O trabalho social é um componente que ganha cada vez mais espaço nos programas habitacionais, depois de muita luta por seu reconhecimento. Se, para qualquer empreendimento habitacional, o trabalho social é fator necessário para a agregação social e convivência, nas iniciativas autogestionárias, é o princípio de qualquer ação.

Historicamente, o trabalho social vem sendo desenvolvido de forma voluntária, pelas próprias organizações, ou até de maneira clandestina, com recursos não explicitados da assessoria técnica e da obra. O MCMV-E trouxe não só a obrigatoriedade de sua execução como a designação de recursos segregados. No MCMV-E 1, esses valores eram de cerca de $0,5 \%$ do valor da obra, na Fase 2 do programa, esses valores chegam a $2 \%$.

O trabalho social na autogestão visa tanto a participação de todos na totalidade do processo quanto a continuidade dessa organização para a vida comunitária. Além disso, traz os valores políticos da organização e da mobilização vinculados à visão de mundo daquele movimento social.

No entanto, a orientação formal dos normativos de TS não faz qualquer distinção sobre o seu conteúdo, quando da autogestão, gerando estranheza e algumas incompatibilidades. Nos processos autogestionários, as famílias não são meros beneficiários das unidades produzidas, mas seu principal agente. Nesse sentido, são tomadores de decisão e, portanto, responsáveis pelo bom andamento do processo.

As entidades têm reivindicado que os recursos para o trabalho social sejam disponibilizados desde a etapa de preparação do grupo e desenvolvimento dos projetos, quando a participação é imprescindível para garantir o andamento do empreendimento. No

\footnotetext{
73 UNMP. Declaração. XII ENCONTRO NACIONAL DE MORADIA POPULAR. Belo Horizonte, 2011.
} 
entanto, os recursos somente são disponibilizados após a contratação da obra, ou seja, depois que todo o projeto já está elaborado e aprovado e que o trabalho de mobilização, discussão de projeto e do programa, caracterização e enquadramento da demanda já tenha sido realizado ${ }^{74}$. Além disso, há críticas de que as regras do projeto de trabalho social têm um formato pouco maleável, o que induz a projetos pouco aderentes ao processo de cada grupo.

Por fim, ainda há discussões sobre o papel das entidades e o dos técnicos sociais. Há casos em que a própria entidade é que assume o TS e outros em que o trabalho dos técnicos está dissociado do processo de organização. Certamente, é um tema recente e que precisa ser mais bem desenvolvido.

\subsection{O Lugar da autogestão na política habitacional}

O PlanHab, elaborado entre 2007 e 2009, reconhece o papel das associações cooperativas e define entre suas diretrizes o estímulo à autogestão e formação de cooperativas para a produção habitacional, garantindo a assistência técnica. Dentro da Linha Programática e de Atendimento para Produção e Aquisição da Habitação, prevê a construção de um subprograma para Promoção por Autogestão de Unidades Habitacionais Urbanas, com o objetivo de

\footnotetext{
promover a oferta de unidades habitacionais urbanas destinadas aos Grupos de Atendimento 1 e 2 por meio da autogestão realizada por entidades privadas sem fins lucrativos (fundações, sociedades, sindicatos, associações comunitárias, cooperativas habitacionais, entre outros tipos de entidades) articuladas com agentes de assistência técnica, cuja atuação está amparada pela Lei 11.124/05. A autogestão envolve a ajuda mútua dos beneficiários finais na produção, gestão e manutenção dos empreendimentos habitacionais que podem ser de propriedade cooperativa. Esse regime de propriedade imobiliária poderá se efetivar a partir de adesões por parte dos moradores desses empreendimentos ${ }^{75}$.
}

\footnotetext{
${ }^{74} \mathrm{Na}$ Compra Antecipada, os recursos podem ser disponibilizados após a compra do terreno.

75 MINISTÉRIO DAS CIDADES. Relatório final do Plano Nacional de Habitação, Brasília, 2008. p. 149.
} 
No entanto, a participação da autogestão na política habitacional continua residual. Apesar de não ser o único fator a ser analisado, é significativo o pequeno peso dos programas autogestionários no volume de recursos destinados e, em consequência, no número de unidades produzidas. Alem disso, poucas ações para fortalecer a capacidade de gestão das associações e cooperativas foram realizadas, tornando o processo muito mais efetivo pela iniciativa das entidades do que de uma política própria para o setor.

O programa MCMV contratou, de 2009 a 2012, o total de 2.279.706 unidades habitacionais, nos diferentes programas. Destas, 1.050.393 tinham sido entregues até 31 de dezembro de 2012. As demais encontravam-se em fase de produção. Esses dados referemse às duas etapas do programa e, as metas, ao período de 2009 a 2010 (MCMV 1 ) e 2011 a 2014 (MCMV 2), ainda em curso (Tabela 4).

Tabela 4 - Quantidades de unidades habitacionais contratadas por faixa de renda MCMV 1 e 2 (2009 - 2013) Posição em 31.dez.2012

\begin{tabular}{l|c|c|c|c|c|c|c|c|c}
\cline { 2 - 9 } & \multicolumn{3}{c}{ MCMV 1 } & \multicolumn{3}{c}{ MCMV 2 } & \multicolumn{2}{c}{ Total } \\
\hline $\begin{array}{l}\text { Renda } \\
\text { (SMs) }\end{array}$ & $\begin{array}{c}\text { Contratad } \\
\text { o (UHs) }\end{array}$ & $\begin{array}{c}\text { Meta } \\
\text { MCMV } \\
\text { (UHs) }\end{array}$ & $\begin{array}{c}\text { Contratad } \\
\text { o (UHs) }\end{array}$ & $\begin{array}{c}\text { Meta } \\
\text { MCMV } \\
\text { (UHs) }\end{array}$ & $\begin{array}{c}\text { Contratad } \\
\text { o (UHs) }\end{array}$ & $\begin{array}{c}\text { Meta } \\
\text { MCMV } \\
\text { (UHs) }\end{array}$ & \begin{tabular}{l}
$\%$ \\
\hline 1
\end{tabular} \\
\hline (0 a 3) & 571.321 & 400.000 & $14 \%$ & 495.351 & 1.600 .000 & $31 \%$ & 978.092 & 2.000 .000 & $49 \%$ \\
\hline 2 & 284.772 & 400.000 & $71 \%$ & 642.267 & 600.000 & $107 \%$ & 1.018 .031 & 1.000 .000 & $102 \%$ \\
\hline (3 a 6) & 149.035 & 200.000 & $75 \%$ & 136.960 & 200.000 & $68 \%$ & 283.583 & 400.000 & $71 \%$ \\
\hline (6 a 10) & 1.005 .128 & $\mathbf{1 . 0 0 0 . 0 0 0}$ & $101 \%$ & $\mathbf{1 . 2 7 4 . 5 7 8}$ & $\mathbf{2 . 4 0 0 . 0 0 0}$ & $53 \%$ & $\mathbf{2 . 2 7 9 . 7 0 6}$ & $\mathbf{3 . 4 0 0 . 0 0 0}$ & $67 \%$ \\
\hline Total & & & & & & & & & \\
\hline
\end{tabular}

Fonte: CAIXA, 2013

No Gráfico 2, as metas e as contratações estão desagregadas por etapa do programa. Na primeira etapa, as metas foram atingidas com pequena distorção, favorecendo a Faixa 1, que contratou $21 \%$ a mais do que o previsto. Na segunda etapa, que ainda está em curso, vê-se que as metas para as Faixas 2 e 3 já foram praticamente cumpridas, em dois anos. Já a Faixa 1, que teve um aumento significativo na meta e na participação relativa no programa, contratou $31 \%$ da meta, tendo ainda mais dois anos para cumpri-la. 
Gráfico 2 - MCMV - Percentual de contratação por faixa de renda em relação à meta

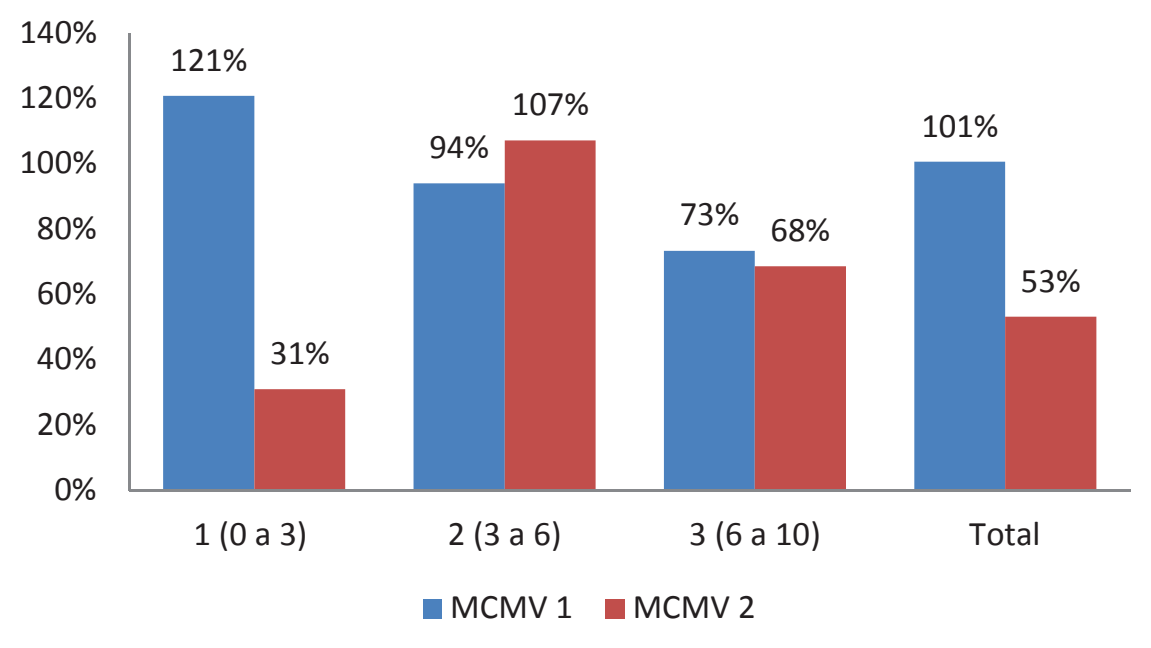

Fonte: Caixa, 2013

Quanto à participação das diferentes modalidades do MCMV, dentro da Faixa 1, desde o lançamento do programa, há uma concentração na modalidade do FAR destinado às construtoras. No entanto, se, na primeira etapa do MCMV, ela superou a meta prevista de contratações, na segunda, apresenta desempenho muito abaixo do esperado. Nessa etapa, o programa passou por momentos de baixa contratação, especialmente quando da pressão das empresas pela elevação do teto do programa.

O MCMV-E sofre diversas alterações no aspecto normativo, na sua segunda etapa, um dos elementos que prejudicou a contratação, além das dificuldades que serão abordadas no Capítulo 5. Já o PNHR teve desempenho acima do previsto, com valores, procedimentos e normativos que foram melhorados, desde a primeira etapa, além da expansão da atuação das entidades, antes muito concentrada no sul do País, para as demais regiões. (Tabela 5). 
Tabela 5 - Distribuição de unidades contratadas e meta na Faixa 1, por programa

Posição em 31.dez.2012

\begin{tabular}{|c|c|c|c|c|c|c|c|c|c|}
\hline \multirow[b]{2}{*}{ Faixa 1} & \multicolumn{3}{|c|}{ MCMV 1} & \multicolumn{3}{|c|}{ MCMV 2} & \multicolumn{3}{|c|}{ Total } \\
\hline & $\begin{array}{c}\text { Contratado } \\
\text { (UHs) }\end{array}$ & $\begin{array}{c}\text { Meta } \\
\text { MCMV } \\
\text { (UHs) }\end{array}$ & $\%$ & $\begin{array}{l}\text { Contratado } \\
\text { (UHs) }\end{array}$ & $\begin{array}{l}\text { Meta } \\
\text { MCMV } \\
\text { (UHs) }\end{array}$ & $\%$ & $\begin{array}{c}\text { Contratado } \\
\text { (UHs) }\end{array}$ & $\begin{array}{l}\text { Meta } \\
\text { MCMV } \\
\text { (UHs) }\end{array}$ & $\%$ \\
\hline FAR & 404.407 & 280.000 & $144 \%$ & 310.505 & 1.260 .000 & $25 \%$ & 714.912 & 1.540 .000 & $46 \%$ \\
\hline Entidades & 9.395 & 15.000 & $63 \%$ & 8.104 & 60.000 & $14 \%$ & 17.499 & 75.000 & $23 \%$ \\
\hline Rural & 5.167 & 45.000 & $11 \%$ & 42.046 & 60.000 & $70 \%$ & 47.213 & 105.000 & $45 \%$ \\
\hline Sub 50 & 63.772 & 60.000 & $106 \%$ & 30.503 & 220.000 & $14 \%$ & 94.275 & 280.000 & $34 \%$ \\
\hline FGTS & 88.580 & & & 104.193 & & & 192.773 & & \\
\hline Total & 482.741 & 400.000 & $121 \%$ & 495.351 & 1.600 .000 & $31 \%$ & 978.092 & 2.000 .000 & $49 \%$ \\
\hline
\end{tabular}

Fonte: Caixa, 2013

O Gráfico 3 demonstra a participação de cada programa, nas duas etapas, na efetiva contratação. Das unidades contratadas, $67 \%$ são dentro do programa destinado às construtoras. Nesses dados, encontram-se também os financiamentos do FGTS nessa faixa de renda, que atende, na maioria das vezes, de forma pulverizada, com financiamento direto às pessoas físicas. Apesar de não ser uma das principais estratégias do programa, foi responsável por $18 \%$ das contratações. Os dois programas que tem entidades como promotoras - MCMV-E e PNHR - somaram apenas $6 \%$ de todo esse montante, com $4 \%$ no PNHR e $2 \%$ no MCMV-E.

Gráfico 3 - Participação de cada programa na Faixa 1 (UHs contratadas/programa)

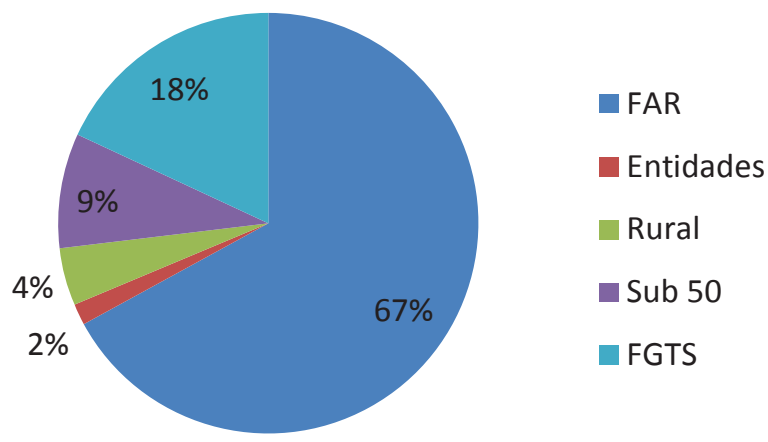


Ao analisar isoladamente os dados dos programas direcionados às entidades sociais PCS e MCMV-E - é possível aferir algumas questões sobre o desenvolvimento do programa e sua efetivação. O PCS foi o primeiro programa federal criado com essa finalidade. Nesse sentido, envolveu grande expectativa em sua capacidade de levar financiamento habitacional diferenciado, em relação às opções existentes até então, no FGTS, e ao baixo valor dos programas subsidiados.

Pode-se dizer que o PCS teve uma "curva de aprendizagem", a qual levou algum tempo, tanto para as entidades se apropriarem do programa, como de adaptação do programa e de seus agentes públicos na sua efetivação. A Tabela $6^{76}$ demonstra essa curva, bem como o início da operação do MCMV-E, que sofreu os mesmos efeitos, além do prazo excessivo para a edição dos normativos do programa.

Tabela 6 - Volume de contratações do PCS e
MCMV-E (unidades habitacionais por ano)
\begin{tabular}{c|r|r|r}
\hline & & MCMV - & \\
\hline 2005 & 1.268 & & 1.268 \\
\hline 2006 & 4.843 & & 4.843 \\
\hline 2007 & 5.612 & & 5.612 \\
\hline 2008 & 8.108 & & 8.108 \\
\hline 2009 & 1.574 & 309 & 1.883 \\
\hline 2010 & 40 & 7.484 & 7.524 \\
\hline 2011 & 50 & 3.099 & 3.149 \\
\hline 2012 & & 7.521 & 7.521 \\
\hline Total & $\mathbf{2 1 . 4 9 5}$ & $\mathbf{1 8 . 4 1 3}$ & $\mathbf{3 9 . 9 0 8}$ \\
\hline
\end{tabular}

Fonte: Caixa, 2013

\footnotetext{
${ }^{76}$ Os dados apresentados diferem em 914 unidades, dos apresentados na Tabela 5, por terem três dias de diferença na apuração dos contratos.
} 
Gráfico 4 - UHs contratadas por ano

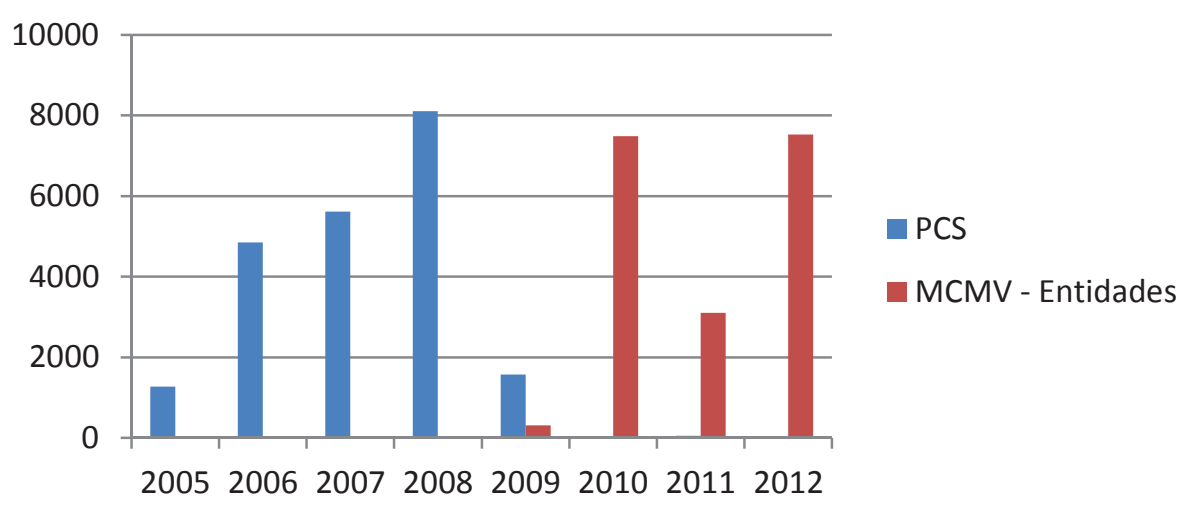

Fonte: Caixa, 2013

Percebe-se, assim, a pequena relevância dada à parceria com as entidades, mesmo em um contexto de investimento massivo em habitação e com metas quantitativas ousadas. Em audiência com a Presidenta da República, em julho de 2012, os movimentos de moradia reivindicam o aumento da meta para o MCMV-E para 200.000 unidades habitacionais e recebem a resposta da presidenta que a meta pode ser aumentada, na medida em que se atinja, antes de 2014, o patamar pré-estabelecido. No entanto, nem as metas intermediarias foram atingidas, como foi demonstrados nos gráficos e tabelas acima.

Nesse sentido, percebe-se que não se trata apenas de disponibilizar recursos, mas de construir formas de apoio e capacidades no poder públicos nas entidades, para essa finalidade, além de remover os entraves para que essa produção se concretize. Como se verá adiante, o tema do acesso à terra é o maior deles. 
3. ACESSO À TERRA URBANA NO BRASIL 
Desatar o nó da terra ${ }^{77}$ é a preocupação principal daqueles que se dedicam a analisar o chamado "pensamento crítico em relação à cidade periférica", como referido por Maricato (2011, p. 101). Preocupação forjada ao longo de décadas e que se opõe à opção generalizada pela propriedade individual, inclusive das políticas habitacionais, que reforçam longa tradição de privatização da terra no Brasil.

A centralidade do tema tem sido registrada por diversos autores, na academia, por movimentos pela reforma urbana e incorporada, inclusive, no discurso governamental dos principais partidos, com suas diversas matizes ideológicas e mais recentemente até o mesmo no discurso de parte do setor imobiliário e da construção civil $^{78}$.

Essa cidade periférica vai se concretizar na expulsão dos mais pobres para as periferias cada vez mais distantes e desprovidas de infraestrutura e oportunidades, na ocupação de áreas ambientalmente frágeis, nos despejos e remoções promovidos por investimentos públicos e privados, na "reserva" dos melhores lugares para o mercado imobiliário atuar, premiando a especulação com a valorização fundiária. A política habitacional oficial, longe de reverter esse quadro, o tem reafirmado, como se verá no Capítulo 4.

Maricato (2011, p. 186) aponta o que resta de cidade para aqueles que não dispõem de meios para acessar a terra mercantilizada:

\begin{abstract}
Nas cidades, a dificuldade de acesso à terra regular para habitação é uma das maiores responsáveis pelo explosivo crescimento de favelas e loteamentos ilegais nas periferias. Na década de 80 , quando o investimento em habitação social foi quase nulo, a taxa de crescimento da população que mora em favelas triplicou em relação à população urbana em seu conjunto. Nos anos 90 , a taxa duplicou. Perto de $12 \%$ da população de São Paulo e Curitiba moram em favelas. Em Belo Horizonte e Porto Alegre, até $20 \%$. No Rio de Janeiro, 25\%. Em Salvador, Recife, Fortaleza, São Luiz e Belém, mais de $30 \%$ das pessoas vivem em favelas. Somandose as moradias ilegais, encontramos aproximadamente $40 \%$ dos domicílios de São Paulo, e 50\% no Rio de Janeiro, em situação irregular.
\end{abstract}

\footnotetext{
${ }^{77}$ Expressão utilizada por Ermínia Maricato como título de artigo publicado em 2011 (MARICATO, E. O nó da terra. In: $O$ impasse da política urbana no Brasil. Petrópolis: Vozes, 2011).

78 CBIC. Position Paper. Terra urbanizada. Disponível em: <http://www.cbic.org.br/sala-deimprensa/position-papers/terra-urbanizada>.
} 
Para Campos (2011, p. 66), a questão do acesso à terra urbana orienta o crescimento periférico das cidades, que:

tem como base, portanto, a questão da terra urbana, na medida em que as terras localizadas em áreas bem infraestruturadas possuem uma renda diferencial em relação às terras distantes do núcleo central (física ou socialmente), localizadas em áreas caracterizadas pela precariedade da infraestrutura e serviços coletivos.

Já no início dos anos 70, Bolaffi (1982, p. 59 e 67), registrava sua preocupação com a relevância do tema ao analisar os motivos que levaram ao fracasso das iniciativas do $\mathrm{BNH}$, a mais ousada iniciativa no campo da habitação popular até então, promovida pela ditadura militar:

Neste sentido, a principal omissão do BNH e dos governos que ditaram a sua política foi, precisamente, não ter formulado uma política fundiária. O problema fundiário constitui um dos principais obstáculos tanto para o barateamento da habitação, como decorrência óbvia do custo representado pelo terreno, quanto para o aumento da eficiência e da produtividade do setor. (...) A resultante do processo, do ponto de vista urbanístico é o padrão periférico do crescimento da metrópole com todas as suas características: baixa densidade de ocupação do solo urbano, aumento das distâncias, ineficiência dos transportes, elevação dos custos sociais e privados da administração pública.

Embora o quadro que ali já era apontado como problemático tenha apenas se deteriorado, independentemente do fato de quantidade significativa de iniciativas pontuais de democratização do acesso à terra tenha sido empreendida ao longo dos anos, o que se verifica é a sobrevalorização do preço da terra. Um elemento que se agrega ao cenário é que o crescimento econômico do País tem ampliado a ocorrência do mesmo fenômeno.

O MCidades, no processo de capacitação dos municípios para a elaboração dos PLHIS, adotou posicionamentos que reconhecem a gravidade dessa situação. Conforme a expressão de Whitaker Ferreira (2009, p. 14):

Do ponto de vista da produção de seu espaço, nossas cidades sofrem o problema da sociedade subdesenvolvida: a subordinação absoluta à lógica dos negócios. Flávio Villaça (2001) mostrou como, na maior parte das capitais do país, verifica-se recorrentemente um eixo de desenvolvimento produzido pelas elites em seus deslocamentos em busca das áreas mais privilegiadas para se viver.

Em uma clara inversão de prioridades, os governos municipais investem quase que exclusivamente nessas porções privilegiadas da cidade, em detrimento das demandas urgentes da periferia. O resultado disso é visível para todos: ilhas de riqueza e modernidade nas quais se acotovelam mansões, edifícios de última geração e shoppings-centers, e que canalizam a quase totalidade dos recursos 
públicos, geralmente em obras urbanísticas de grande efeito visual, porém de pouca utilidade social.

Este capítulo retoma alguns aspectos da formação histórica e analisa a modificação no significado e na forma de uso da terra no País. Em síntese, do Brasil-Colônia aos dias atuais, passou de suporte físico-territorial para o projeto expansionista da coroa portuguesa para a condição de principal ativo virtual no processo de financeirização da política urbana, no estágio atual da política urbana das cidades, especialmente os das grandes cidades.

\title{
3.1 Aspectos históricos do processo de apropriação da terra no Brasil
}

O início da história da apropriação da terra no Brasil remonta ao período medieval, numa época de predomínio da Igreja Católica sobre a fragilidade da formação de EstadosNação. Nesse contexto, documentos, ora expedidos pela Igreja Católica, ora pelos próprios países interessados, justificaram o processo de ocupação das terras no bojo da expansão ultramarina. A apropriação do território brasileiro foi juridicamente justificada pelo chamado Tratado de Toledo (1480), pela Bula Inter Coetera (1493) e o Tratado de Tordesilhas (1494).

A Coroa Portuguesa iniciou o processo de colonização por meio do mecanismo das capitanias hereditárias ${ }^{79}$, que, conforme a apuração de Diniz (2005, p. 1),

\begin{abstract}
eram imensos tratos de terras que foram distribuídos entre fidalgos da pequena nobreza, homens de negócios, funcionários burocratas e militares. Entre os capitães que receberam donatarias, contam-se feitores, tesoureiros do reino, escudeiros reais e banqueiros.
\end{abstract}

Registre-se também e ainda com o suporte da autora, que a eles eram transferidos os poderes deveres de representação do Rei como administradores e delegados, com jurisdição sobre o colono português ou estrangeiro para a defesa do Reino e da religião. A eles cabia transferir a terceiros, parte dos poderes inerentes aos de proprietário.

\footnotetext{
${ }^{79}$ Capitanias hereditárias eram um estabelecimento militar e econômico voltado para a defesa externa e para o incremento de atividades capazes de estimular o comércio português.
} 
Mas, ao largo da titularidade jurídica da terra em favor da Coroa Portuguesa, ocorria a ocupação de fato, num processo marcado pela multiplicação de formas legais e ilegais de acesso à terra, desprovidos de registros públicos seguros e conduzidos por interesses conflituosos. A história da apropriação da terra, seja urbana ou rural, constitui um dos elementos explicativos da desigualdade físico-territorial ainda vigente.

Mas a característica relevante desse instrumento é que reservava à Coroa a manutenção da propriedade da terra, constituindo-se mais em uma fórmula de transferência do patrimônio público ao privado do que um processo de colonização com vistas ao desenvolvimento econômico da colônia. Em seguida, o fracasso do modelo levaria ao seu desdobramento nos modelos de subdivisão das capitanias nas chamadas sesmarias e suas subdivisões. Como ensina Diniz $(2005$, p. 2):

\begin{abstract}
$\mathrm{Na}$ época da colonização, pode-se distinguir o direito de caráter jurídico e o poder real de usufruir. A terra continuava a ser patrimônio do Estado português. Os donatários possuíam o direito de usufruir a propriedade, mas não tinham direitos como donos. Estavam, então, submetidos à monarquia absoluta e fortemente centralizada. Os capitães-donatários detinham apenas $20 \%$ da sua capitania e eram obrigados a distribuir os $80 \%$ restantes a título de sesmarias, não conservando nenhum direito sobre as mesmas.
\end{abstract}

A sesmaria nasce como desdobramento do modelo anterior, reproduzindo e radicalizando os vícios característicos das relações patrimonialistas desenvolvidas em Portugal, mas, dadas as condições políticas da época, não pôde ser transplantada como mera reprodução do modelo original, de caráter distributivo, mas sofre clara adaptação ao ambiente onde proliferava o domínio dos mais fortes, muitas vezes à margem das tentativas de regramento introduzidas pela Coroa. Prado Júnior define assim a condição política da época (1953, p. 28-29):

Até meados do século XVII pode-se afirmar que a autoridade desta (a Coroa) somente se exerce dentro dos estreitos limites da sede do governo-geral. Mantinha ela na colônia apenas uma administração rudimentar, o estritamente necessário para não perder com ela todo contato, e atendia a seus pedidos com a relutância e morosidade de quem não se decide a fazer grandes gastos com o que não the pagava o custo. Não raro por isso fechavam os olhos a toda sorte de abusos que não tinham forças para reprimir ou castigar. (...) tais circunstâncias condicionam a estrutura política da colônia. São elas que explicam a importância das Câmaras Municipais, que constituem a verdadeira e quase única administração da colônia. (...). O poder das Câmaras é, pois, o dos proprietários. (...). Se dentro do sistema político vigente na Colônia só descobrimos a soberania, o poder político da Coroa, vamos encontrá-lo, de fato, investido nos proprietários rurais, que o exercem através das administrações municipais. 
Assim, o modelo de ocupação da terra pensado como suporte mercantil lucrativo para atrair os recursos disponíveis - já que a Coroa não possuía meios de investir na colonização -, consumando-se numa forma de solucionar as dificuldades e promover a inserção do Brasil no Antigo Sistema Colonial, transforma-se em fonte permanente de conflitos fundiários e reprodução de modos de apropriação da terra que fundamentaram o nascimento das estruturas latifundiárias que ainda hoje vigoram em grande parte do território do País.

Mas a fragilidade da atuação da Coroa, aliada a fatores como o tamanho do território, delinearam nova configuração aos instrumentos, cujas características distorceram sua aplicação. Das características próprias que o mecanismo assume no País, Faoro (2001, p. 141) chama a atenção para o fato de que "a realidade americana torce o conteúdo da lei, transformando a terra, de instrumento régio de colonização e povoamento, em garantia permanente do investimento agrícola".

O modelo das sesmarias, ao ser transplantado para o Brasil, adota características complementares, ou "adaptações", entre as quais pode se destacar o dever de contribuir para com a proteção das terras portuguesas e a obrigação de produzir a monocultura da cana-de-açúcar para exportação do excedente.

Assim, o sistema de sesmarias, que já vinha sendo implantado na Europa desde o século XIII, e que lá possuía caráter redistributivo, pois a partir de pequenos lotes, incentivava o cultivo da terra e a ocupação do território, ao ser transplantado para a Colônia se desenvolve afirmando desigualdades, favorecendo o surgimento de grandes latifúndios e perenizando conflitos fundiários resolvidos por meio da violência, sem a mediação do Estado.

Ou seja, diversas razões, de ordem jurídico-econômica, entre as quais pode se destacar o fato de que a titularidade da terra ainda permanecia em nome da Coroa Portuguesa, ou mesmo das ordens religiosas, limitando os interesses dos sesmeiros; o problema da ausência de uma legislação pormenorizada e eficiente que regulasse a transferência dos direitos de sesmeiros a terceiros; a precariedade da demarcação dos 
limites das áreas ocupadas e a ocupação irregular da terra, levaram ao surgimento e fortalecimento da figura do posseiro e obrigaram a Coroa a tolerar a existência de sistemas legais e ilegais de apropriação da terra no Brasil.

O patrimonialismo brasileiro, embora não seja toda a explicação, pode ser visto como origem de boa parte de nossos problemas no campo fundiário. No Brasil, os autores que se dedicaram ao tema ${ }^{80}$ demonstram que o patrimonialismo decorre da implantação, no País, desde o processo de concessão de terras, de honrarias, favores diversos e poderes quase absolutos aos senhores de terra, influenciando uma prática político-administrativa em que o público e o privado não se distinguem perante as autoridades.

Ainda que se reconheça que ocorreu certo enfraquecimento do patrimonialismo na vida brasileira, ainda no período Imperial (FERNANDES, 1975), também é possível constatar que foi exatamente nesse período que ele alcançou seu mais significativo nível de influência nos assuntos nacionais, por volta da metade do século XIX. É também nesse período que a propriedade da terra passa a exercer papel importante na formação do capitalismo brasileiro.

\subsection{A lei de terras e o surgimento da propriedade privada, individual e absoluta}

O instituto da propriedade privada da terra, como a conhecemos nos dias atuais, ganha relevância no século XVIII, no esteio da formação dos estados nacionais pósrevolucionários, quando é reconhecido como direito individual fundamental da pessoa humana, expressão máxima da liberdade do cidadão frente ao poder do Estado ${ }^{81}$.

\footnotetext{
${ }^{80}$ Raimundo Faoro, Sérgio Buarque de Holanda, Victor Nunes Leal, entre outros.

${ }^{81}$ A Declaração Universal dos Direitos do Homem, de 1789, considera a propriedade como um direito natural, inviolável e sagrado.
} 
O transplante dessa concepção para o sistema jurídico brasileiro é precedido por longo período histórico de apropriação da terra, marcado profundamente pela herança patrimonialista portuguesa, modelo que diversas vezes coloca em conflito os interesses da elite local com o modelo liberal, que começava a tomar corpo nos circuitos europeus com repercussão na formação da nova intelectualidade brasileira.

Esse período de transição da propriedade semipública para a propriedade privada da terra, conforme ressalta Smith (2008, p. 304) põe em evidência um processo de amplo apossamento de terras, que caracterizará, no País, "a formação do latifúndio, na sua forma mais acabada. O latifúndio avançará sobre as pequenas posses, expulsando o pequeno posseiro em algumas áreas, num deslocamento constante sobre as fronteiras abertas".

Na mesma direção, Gorender registra que (1988, p. 307):

de 1822 a 1850, foi a posse a única via de acesso à apropriação legítima das terras públicas. Mas uma via de acesso aberta a grandes e pequenos. Se o número destes últimos cresceu com rapidez, surgiram também as posses de vastas dimensões. A Lei no 601 obstruiu a via da posse, proibindo as aquisições por outro título que não o de compra.

O enfrentamento ao caos fundiário verificado no início do século $X I X$, que se aprofunda, se dá pela criação da Lei 601/1850, conhecida como Lei de Terras. A iniciativa buscava ordenar a situação fundiária por meio da instituição da compra e venda de imóveis, das terras devolutas ${ }^{82}$, pela revalidação das sesmarias anteriormente concedidas e efetivamente utilizadas e pelo reconhecimento da posse que cumprisse sua função social.

Ou seja, na relação de hipóteses de regularização oferecidas na lei, havia mecanismos de democratização do acesso à terra. Conforme relembra Melo (2008, p. 41), a lei "acabaria por atribuir ao Império um enorme banco de terras", mas, longe disso, representou a formalização da propriedade privada e individual da terra, com as conhecidas características de inacessibilidade aos trabalhadores assalariados, aos escravos e às comunidades tradicionais.

\footnotetext{
${ }^{82}$ Terras devolutas são terrenos hoje considerados públicos por determinação constitucional, pois nunca pertenceram a um particular, ainda que tenham sido apropriadas ilegalmente. Com o fim do regime das sesmarias, tornaram-se devolutas as terras que não foram regularizadas, assim como as que foram dadas para o cultivo e depois retomadas, ante a ausência de uso, por meio de uma sanção denominada comisso.
} 
No Brasil, a propriedade da terra começa a se desenvolver num contexto précapitalista, em que a terra ainda não exercia papel central no modelo de desenvolvimento. Relembra Martins, (2010, p. 41) que: "mais valiosos que a terra eram os escravos. Isso porque antes de seu aparecimento ali o valor venal da terra era nulo. (....) Assim, a fazenda nada mais representava senão o trabalho escravo acumulado".

Como anota Whitaker Ferreira (2005, p. 3):

tal situação consolidou a divisão da sociedade em duas categorias bem distintas: os proprietários fundiários de um lado, e do outro, sem nenhuma possibilidade de comprar terras, os escravos, que seriam juridicamente libertos apenas em 1888, e os imigrantes, presos à dívidas com seus patrões ou simplesmente ignorantes de todos os procedimentos necessários para obter o título de propriedade.

As transformações em nível mundial, no século XIX, especialmente decorrentes da Revolução Industrial e das mudanças nas relações de trabalho, vão impactar diretamente as relações com a terra no Brasil. Silva (1998, p. 16) afirma que:

\begin{abstract}
Em meados do século XIX articulam-se os interesses da modernização da agricultura e do desenvolvimento manufatureiro, ambos dependentes da criação de um mercado de trabalho livre e de mercado urbano no Brasil. Para esses objetivos o fim do tráfico de escravos e a necessidade de expropriar os trabalhadores livres de todos os seus meios de subsistência para que eles fossem forçados a vender sua força de trabalho. Ao não ter nem um pedaço de chão, esses trabalhadores dependem em tudo do salário e do mercado de produtos.[...]. Nesses dois aspectos as regras de acesso à terra rural e urbana vigentes comportavam-se como um entrave. Se a terra continuasse a poder ser obtida a partir da legalização de posses, por que razão os imigrantes e os ex-escravos escolheriam trabalhar como assalariados para os fazendeiros ou nas indústrias? Esses problemas eram certamente mais cruciais do que os expressados no discurso liberal da época, influenciado pelo direito à propriedade como aspiração da revolução burguesa, concretizada na Constituição dos Estados Unidos da América (1789) e no Código Napoleônico da França (1804).
\end{abstract}

A relação entre a Lei de Terras e o fim da escravidão no Brasil é abordada por inúmeros autores e consagrada na afirmação de Martins (2010, p. 47): "Se no regime Sesmarial, o da terra livre, o trabalho tivera de ser cativo; num regime de trabalho livre a terra tinha de ser cativa", dando as bases para os primeiros passos do capitalismo no Brasil, na forma em que se estruturou até os nossos dias.

Esse retrato da metamorfose da renda capitalizada marca definitivamente a forma pela qual a apropriação da terra passa a influir na consolidação do capitalismo brasileiro, 
constituindo-se na base sobre a qual se desenvolverão nossas cidades. Esta também é a conclusão de Mariana Fix (2011, p. 141), para quem:

\footnotetext{
No Brasil, tal como discute Martins, a renda territorial capitalizada é engendrada no bojo da crise do trabalho escravo como meio para garantir a sujeição do trabalho ao capital, como substituto da expropriação territorial do camponês que, no advento do capitalismo, criou a massa de deserdados apta a entrar no mercado de trabalho da nova sociedade. A renda da terra surge, assim, da metamorfose da renda capitalizada na pessoa do escravo.
}

O resultado dos processos interpretados pelos autores citados neste item demonstram que o objetivo do projeto imperial era demarcar as terras devolutas, vendê-las, promover um projeto de colonização e financiar, com o dinheiro das vendas, a imigração estrangeira para o País. Essa tensão entre os interesses da elite dirigente com os senhores de escravos, com os escravos em processo de libertação e com os imigrantes que chegavam ao País, marcaram profundamente o conceito de propriedade e a forma como nossas cidades se constituíram e quão excludentes se converteram.

\subsection{A privatização da política fundiária no Brasil}

\subsubsection{A hegemonia da propriedade privada}

O direito à propriedade, sua conformação jurídica, os modos de aquisição e utilização exercem importante função simbólica na manutenção dos sistemas político, econômico e ideológico, com suas variações conjunturais, razão pela qual, ao mesmo tempo em que se constitui como elemento central nos programas habitacionais, também representa sua principal deficiência.

A noção de propriedade privada da terra, instituída no século XIX, prevalece até os nossos dias, ainda que, em termos formais, tenha incorporado a função social, como um princípio a ser observado, mas cuja aplicação ainda é pouco percebida na mediação dos diversos tipos de conflitos fundiários. Para a configuração dessa modalidade, ocorrem também, lateralmente, o fortalecimento de um sistema de hipotecas vinculado ao preço da 
terra e a criação de um sistema de registro de imóveis ao qual compete a segurança e a publicidade da informação sobre a condição proprietária.

Surgidas no meio rural, as tensões acompanham o processo de urbanização do País, conforme a síntese de Rolnik (2007, p. 22):

A história dos usos da terra urbana é em parte a história da apropriação do espaço através tanto da ocupação real quanto da propriedade legal. Duas questões podem ser apontadas aqui: a raiz da noção de que o direito à terra está diretamente ligado a sua utilização, que remonta a própria ordem jurídica portuguesa, e a convivência entre um sistema oficial de concessão e um registro de terras virtual e acessível a poucos com a realidade do apossamento informal. Esta contradição que, como vimos, não representava um problema ou uma fonte de conflito até 1850 , passou a ser o elemento fundamental de tensão urbana a partir dessa data até os nossos dias.

Diversos autores comentam o fato de que o instituto da propriedade assume as características de seu tempo histórico, mas no cenário brasileiro não se encontram exemplos de estímulo ao desenvolvimento de outros tipos de propriedade se não aquela privada, individual e absoluta. O Brasil não estimula o desenvolvimento de outras modalidades de aquisição da propriedade e mesmo o reconhecimento dos direitos de comunidades tradicionais permanece como uma promessa não cumprida ${ }^{83}$.

As estruturas de comunicação dos governos têm se empenhado em manter acesa a chamada ideologia da casa própria, num esforço permanente que reforça a importância da propriedade privada, colocando-a inclusive em posição superior a de que o importante é a garantia da condição digna de moradia e não apenas sua aparência. A ideologia da casa própria é assim definida por Bolaffi (1981, p. 43):

É que a pequena classe média e o operariado urbano no Brasil vivem permanentemente a contradição entre as expectativas de ascensão social, a necessidade de demonstrar publicamente esta mesma ascensão, e um poder aquisitivo cada vez mais reduzido. Vive, portanto, entre a angústia do crediário e a necessidade de consumir mais. Subjetivamente a aquisição de um imóvel se constitui na principal evidência de sucesso e de conquista de uma posição social mais elevada. Objetivamente, a casa própria não só melhora as condições de acesso ao crediário, como libera o orçamento familiar da despesa com aluguel.

\footnotetext{
${ }^{83} \mathrm{O}$ reconhecimento do direito à propriedade da terra indígena, ou dos remanescentes quilombolas, apenas foi formalmente incorporado na Constituição de 1988 e até hoje enfrenta fortes resistências para sua efetivação.
} 
O acesso à terra urbanizada também é elemento central para a compreensão da atualidade da ideologia "da casa própria" - recentemente revitalizada pelas estratégias de comunicação governamental ao denominar "Minha Casa, Minha Vida" o principal programa de produção habitacional do governo brasileiro, incluindo dentre seus destinatários a população de menor renda.

Embora existam diversas modalidades de fixação do cidadão no território, a opção do programa e apresentado como o único caminho possível, nos programas de produção habitacional desenvolvidos por todos os níveis de governo, é a consolidação do acesso à terra por intermédio exclusivo da propriedade privada e individual.

Ao longo do tempo, as formas artesanais de apossamento da terra, como a posse, cessão de datas, com precariedade de registro, foram sendo gradativamente substituídas pela introdução do elemento monetário como forma exclusiva de aquisição da propriedade como sustentáculo da introdução do capitalismo monopolista do período pós-colonial. Além disso, outras formas de reconhecimento da posse da terra, como a usucapião, embora legalmente reconhecidas, encontram, até os dias de hoje, imensas dificuldades de efetivação.

Os movimentos por reforma urbana defendem, entre as possibilidades de solução do problema habitacional, a utilização da propriedade coletiva da terra e da moradia, com base na experiência uruguaia, que, conforme relata Baravelli (2006, p.68,69): “converte em usuários ao invés de proprietários, uma vez que passam a ser detentores de um 'derecho de uso' sobre a residência que a cooperativa lhes designar".

A defesa da propriedade coletiva, presente em diversos fóruns de discussão da política urbana, cuja premissa é priorizar a garantia de sobrevivência para os membros de uma comunidade, como é particularmente utilizada no modelo da produção cooperativista uruguaia, demonstra que, em certas condições, ainda há viabilidade no tempo atual para a utilização dessa modalidade.

A apropriação coletiva da terra, por um lado, não representa a superação do modelo capitalista de organização da sociedade, mas pode se constituir em modalidade útil à preservação dos direitos de comunidades fragilizadas, na medida em que cria um ambiente 
comum de resistência à especulação imobiliária e seus efeitos no processo de exclusão territorial urbana.

\title{
3.3.2. Terra urbana na hegemonia do capital financeiro
}

O debate sobre o acesso à terra urbana ainda ocupa espaço central na discussão sobre os problemas urbanos, também porque ela se tornou uma mercadoria cujo preço parte de um patamar inacessível à população de menor renda e multiplica-se, historicamente, beneficiando-se também das vantagens governamentais.

Singer (1982, p. 23 e 35) analisa o papel central da propriedade na disputa pelo uso do espaço urbano por meio da apresentação da sua teoria sobre a formação do preço da terra. Para o autor:

\begin{abstract}
Ao contrário dos mercados de produtos do trabalho humano, em que os preços giram ao redor de uma média constituída pela soma dos custos de produção e da margem de lucro capaz de proporcionar a taxa de lucro média sobre o capital investido, os preços no mercado imobiliário tendem a ser determinados pelo que a demanda estiver disposta a pagar". [...] As transformações no preço do solo acarretadas pela ação do Estado são aproveitadas pelos especuladores, quando estes têm possibilidade de antecipar os lugares em que as diversas redes de serviços serão expandidas. No entanto, esta antecipação nem sempre é factível e quando o é a concorrência entre especuladores pode forçar a elevação do preço antes que o melhoramento previsto se realize, reduzindo sobremaneira os ganhos futuros da operação. Para evitar que isso se dê, a especulação imobiliária procura influir sobre as decisões do poder público quanto às áreas a serem beneficiadas com a expansão dos serviços.
\end{abstract}

Além disso, a demanda por terra urbanizada conta hoje com a conjugação de dois esforços importantes. De um lado, a ação estatal, que reverte grandes somas seja em projetos públicos ou em parcerias com o setor privado. E, de outro, se cristalizam grandes conglomerados econômicos, com estratégias agressivas em relação à aquisição de terras, para convertê-las em ativos financeiros que constituem o capital a ser transacionado em complexas operações financeiras. Esse processo contrapõe a determinação institucional por um grau maior de distributividade da terra, representada pela legislação urbano-ambiental, 
em relação a processos de maximização da extração de mais-valia urbana da terra por meio da financeirização dos ativos em operações praticadas nos mercados especulativos.

Mas encontramos, na história da apropriação da terra, alguns elementos que contribuem para a compreensão da forma como a aquisição da propriedade confronta a ideia de uma política urbana redistributiva, favorecendo a multiplicação de cidades marcadas pela distância entre o interesse da coletividade e a possibilidade de multiplicação dos lucros de setores privados cuja natureza também se encontra em transformação.

A síntese da reconstrução histórica do processo de cristalização do modelo tradicional de propriedade e do desenvolvimento do mercado imobiliário, seja por meios das ações privadas ou das políticas governamentais de incentivo, permite constatar que a evolução da função básica da propriedade de suporte do modelo de agroexportação précapitalista passa à condição de "ativo financeiro puro e reduzida a um campo especial de circulação do capital portador de juros", conforme diz Fix (2011, p.195).

A terra urbana agora não serve apenas aos interesses da burguesia nacional, mas transforma-se - a olhos vistos - em ativo financeiro de empresas e interesses transnacionais que se digladiam na busca por novas oportunidades de negócios, em que os sistemas institucionais internos de cada cidade são claramente moldados para facilitar a reprodução desse modelo.

Novamente Fix (2011, p. 195) desnuda a mecânica dessa operação:

\begin{abstract}
O movimento é duplo. As empresas brasileiras se capitalizaram recorrendo ao mercado de capitais. Visto de outra perspectiva, a nuvem de capital financeiro internacional encontrou um canal de conexão com um circuito imobiliário antes reservado às elites locais. Capitalizado, o setor encontrou barreiras próprias da formação social brasileira que procurou contornar por meio de inovações de vários tipos: na organização da empresa, nos instrumentos financeiros e urbanísticos, nos produtos imobiliários e no canteiro de obras.
\end{abstract}

Além disso, esse processo implicou a "modernização" do sistema jurídico que rege, por exemplo, os financiamentos imobiliários, com a regulamentação da alienação fiduciária ${ }^{84}$

\footnotetext{
${ }^{84}$ Por alienação fiduciária entende-se a transferência da propriedade de um bem, em nosso caso, um bem imóvel, à instituição credora, em garantia de pagamento de uma dívida, enquanto que o devedor continua utilizando o bem alienado, tendo a posse e não a propriedade. A propriedade do bem é devolvida ao seu titular
} 
- que anteriormente aplicava-se apenas aos bens móveis - nos contratos de crédito imobiliário e a instituição do chamado patrimônio de afetação ${ }^{85}$, entre outras alterações pontuais no sistema financeiro, completaram as garantias necessárias para a aceleração do crescimento do mercado imobiliário.

O interesse das empresas do setor imobiliário reside na possibilidade de ampliar a lucratividade do processo produtivo e a ela somar o lucro da renda da terra, maximizado pela possibilidade concreta de aumentar a demanda. Cardoso, Aragão e Araújo apontam essa nova perspectiva (2011, p. 6):

\begin{abstract}
O ganho com a redução do preço pago pela terra é de natureza mercantil e pode ser definido como lucro imobiliário, enquanto os ganhos com a redução do custo de construção são de natureza propriamente produtiva e podem ser definidos como lucro da construção. O lucro imobiliário é maximizado com a capacidade das empresas em desenvolver estratégias de redução do valor pago aos proprietários, exemplo: com a construção de estoques de terras, com a transformação de solo rural em urbano, ou ainda com a possibilidade de antecipar mudanças na legislação de uso do solo que viabilizem a utilização de terrenos até então fora do mercado. Já o lucro da construção se viabiliza com a ampliação da escala, racionalização do processo produtivo, redução de perdas, aumento da produtividade e utilização de novas tecnologias.
\end{abstract}

Para o setor privado, não basta especular e apropriar-se individualmente do esforço coletivo que produz as mais-valias urbanas, é preciso também maximizar os lucros do processo de especulação imobiliária convertendo a renda da terra em ativo virtual que alavanca os fluxos financeiros dos mercados em tempo de transações econômicas complexas, operadas com forte vinculação ao capital especulativo internacional.

Como afirma Fix, são tempos de parcerias para a exclusão ${ }^{86}$, que podem se manifestar em megaprojetos, cuja função é retroalimentar o próprio processo de

depois que ele quitar a obrigação assumida. O modelo inicialmente pensado para a utilização nos contratos do Sistema Financeiro Imobiliário, cujas operações se destinam à população de maior renda, paulatinamente foi transferido ao chamado segmento econômico, inclusive nos empreendimentos da Faixa 1 do Programa Minha Casa Minha Vida. Em síntese, a vantagem do uso dessa modalidade de garantia é a rapidez do procedimento de retomada do imóvel, em caso de inadimplência do credor, num procedimento extrajudicial. Essa conformação jurídica retoma, para o processo de reintegração na posse, o procedimento sumaríssimo utilizado na época da ditadura militar.

${ }^{85}$ O Patrimônio de Afetação é a segregação patrimonial de bens do incorporador imobiliário para uma atividade específica, com o intuito de assegurar a continuidade e a entrega das unidades em construção aos futuros adquirentes, mesmo em caso de falência ou insolvência do incorporador.

${ }^{86}$ No livro Parceiros da Exclusão: Duas Histórias de Construção de uma Nova Cidade em São Paulo: Faria Lima e Água Espraiada (São Paulo: Boitempo Editorial, 2001), a pesquisadora analisa criticamente o processo de 
especulação imobiliária de determinada área da cidade ou ser incorporada em programas públicos de caráter anticíclico, como ocorre no Minha Casa Minha Vida. Nos grandes centros econômicos do País, a nova forma de relações estado-capital na política habitacional é na construção das parcerias público-privadas.

Ao lado do esforço desempenhado pelo chamado movimento por reforma urbana, no sentido de viabilizar o cumprimento da função socioambiental da propriedade, agigantase o papel do mercado imobiliário, com radical financeirização e internacionalização.

Daí entender como correta a conclusão de Fix (2011, p. 223) no sentido de que "a desmercantilização da terra, que poderia sugerir outras condições de vida urbana, é, em grande medida, derrotada em favor da expansão de um padrão de acumulação de riqueza que impõe, ao urbano, seu projeto".

\subsection{Instrumentos urbanísticos: As promessas continuam válidas?}

Admitindo que as desigualdades vistas nas cidades brasileiras tenham, portanto, suas causas nas formas como se organizou nossa sociedade, importante analisar também as principais respostas elaboradas, em tempos democráticos, a essa herança.

O Estatuto da Cidade é tido, inclusive em termos internacionais, como moderno mecanismo legislativo de implantação da política urbana. Regulamenta o capítulo de política urbana da Constituição e relaciona diretrizes e instrumentos com o objetivo de contribuir para a construção de cidades justas e sustentáveis.

Qualifica o direito à cidade como a possibilidade de acesso a cidades ambientalmente sustentáveis, à terra urbana, moradia, ao saneamento ambiental, à infraestrutura urbana, ao

apropriação de áreas dotadas de infraestrutura por setores do mercado imobiliário num processo embrionários de inversão de recursos públicos para o favorecimento dos interesses privados nacionais e internacionais ao custo da exclusão da população mais pobre, então residente nessas áreas. 
transporte e aos serviços públicos, ao trabalho e lazer, para as presentes e futuras gerações e reafirma a função social da propriedade e a gestão democrática das cidades.

O conjunto de leis que regula a questão urbana é majoritariamente dominado por afirmações redistributivas, cujo objetivo é dar validade aos princípios constitucionais de promover a dignidade humana por meio da construção de uma sociedade livre, justa e solidária, garantindo o desenvolvimento nacional, a erradicação da pobreza e da marginalização e a redução das desigualdades sociais e regionais.

A função social da propriedade foi incluída pela primeira vez no ordenamento constitucional de 1934 e atualmente está prevista nos artigos 5으, XXII, XXIV, XXVI; 170 III; 182, caput; 185 parágrafo único, e 186, todos da Constituição. O novo Código Civil (que regula as relações entre particulares) foi na mesma direção, reproduzindo em seu artigo 1.228, §1으, essa concepção, acrescentando a preocupação ambiental. A Lei 10.257/2001 (Estatuto da Cidade), em seu artigo 2º, e a Lei 9.636/1998 (Lei de Terras da União), reforça essa configuração jurídica.

Todos reconhecem que a lei não transforma por si a realidade. Aliás, essa tarefa é de todos os integrantes da sociedade em suas ações cotidianas. Entretanto, essa ferramenta institucional é que permite afirmar que a função social da propriedade evoluiu de mero conceito filosófico para agregar os atributos de efetividade. Portanto, a nova propriedade hoje está configurada com maior limitação, pois precisa ser entendida a partir do reconhecimento de três aspectos fundamentais: a) privação de determinadas faculdades; b) complexo de condições para o exercício da condição de proprietário; c) obrigação de exercer determinadas ações.

A propriedade é um objeto em disputa pela concepção moderna da política urbana que, conforme a literatura reconhece, foi fortemente influenciada pela ação efetiva do movimento por reforma urbana. Na síntese do Fórum Nacional por Reforma Urbana (2002):

Entendido como a prevalência na formulação e implementação das políticas urbanas de interesse comum sobre o direito individual de propriedade, implicando no uso socialmente justo e ambientalmente sustentável do espaço urbano. Inclui a obrigação dos órgãos governamentais de regular e controlar o desenvolvimento urbano através de políticas territoriais que visem priorizar a produção social do habitat em observância aos interesses sociais, culturais e ambientais coletivos sobre os individuais. 
A função social da propriedade é o princípio norteador da regulação pública sobre o direito de propriedade urbana, visando a garantia do direito da população excluída e marginalizada de acesso à terra urbanizada.

Pode-se dizer, por fim, que o objetivo da função social incorporada ao direito de propriedade é o de não tolerar a sua ociosidade e promover a captação privada dos resultados dos investimentos públicos. E a função é dada, na legislação, objetivamente, conforme o que estiver disposto no Plano Diretor de cada município.

Por isso, ainda que se reconheça que a configuração da propriedade da terra encontra-se num processo de internacionalização jamais visto, conforme os argumentos anteriormente adotados, também é necessário reconhecer que o controle ou alteração desse quadro está no âmbito local. Das interpretações mais otimistas até as visões mais derrotistas em relação ao tema, ao menos uma questão parece ser comum a todos os que se dedicam ao tema: a maior ou menor aplicabilidade dos instrumentos e estratégias destinados a democratizar o uso do solo, depende a ação afirmativa do ente estatal. E o primeiro a ser chamado, nesse caso, é o ente municipal.

Mas, antes de anotar alguns aspectos do processo de implantação do Estatuto das Cidades, é preciso registrar que a Constituição, de um lado, incorpora um anseio geral pela realização de necessidades que há séculos estavam reprimidas pela ação elitista do Estado e, por outro, contempla também um anseio por descentralização, cujas raízes mais profundas estavam ancoradas numa perspectiva internacional e cujas razões mais concretas estavam ligadas à necessidade de retomar a ação pública para a sociedade, depois do longo período de intervenção militar.

A Constituição Federal de 1988 abre espaço para o estabelecimento de novo acordo político institucional entre vários atores sociais. Por isso, é das poucas que reconhecem o município como integrante da estrutura do estado, com autonomia própria, ou seja, como ente federativo.

Mas a mera definição federalista não qualifica o que é praticado no País, pois o que se vê é um tipo de federalismo que, em primeiro lugar, se direciona a uma estrutura político- 
territorial arcaica e, além disso, desenvolvido a partir de uma lógica administrativa que descentralizou responsabilidades em proporções inferiores aos recursos disponibilizados.

Em relação à herança histórica, afirmam Nogueira e Pires (2008, p. 31):

O federalismo pátrio (...) adota a república como forma de governo, e a federação como forma de Estado, decisão política que se ancorava nas antípodas de oligarquias fortemente antidemocráticas, representadas pelos poderosos locais, cuja formação tem suas origens na Colônia.

Mas a adaptação dessa teoria internacional não ocorre evidentemente sem desconsiderar a realidade local, com suas características já realçadas no início deste capítulo. O peso do município no encaminhamento dos assuntos públicos há muito se constituía como extensão do braço dos proprietários das terras. Dos mesmos autores, a seguinte conclusão é elucidativa desses aspectos (2008, p. 32 e 41):

Tal consagração para alguns, apresentou-se como solução tardia, uma vez que as estratégias descentralizantes de há muito já se haviam implantado no Brasil, consoante lembra Maria Helena Ferreira da Câmara, ao asseverar que as dimensões continentais do país e as diversidades regionais contribuíram, desde os tempos coloniais, para a descentralização político-administrativa, considerando-se que os primeiros sistemas administrativos adotados por Portugal eram medidas que antecipavam ideias de reestruturação do poder em moldes de compartilhamento [...] No Brasil, assim, a previsão constitucional é emblemática e, aliada a pródigas referências ao ente local, sinaliza inversão do movimento expansionista do poder central e anuncia a ampliação do campo autônomo do Município. Uma leitura do texto da Constituição mostra a preocupação do constituinte em enaltecer o ente local, quer nominalmente, quer na definição de competências centralizadas em relação a uma gama considerável de matérias. A ênfase no Município se dá, ainda no reconhecimento de seu papel como importante agente de políticas públicas, e, especialmente, na dedicação de comandos básicos e preordenadores da lei orgânica que o desvencilham da ordem estadual no tocante a sua organização.

O elemento inovador da forma federalista adota a valorização da condição do município, suporte necessário à realização prática dos objetivos da nação. Conforme Saule Júnior e Rolnik (2002, p. 28):

O Município, com base no artigo 182 e no princípio da preponderância do interesse, é o principal ente federativo responsável em promover a política urbana de modo a ordenar o pleno desenvolvimento das funções sociais da cidade, de garantir o bem-estar de seus habitantes e de garantir que a propriedade urbana cumpra sua função social, de acordo com os critérios e instrumentos estabelecidos no Plano Diretor, definido constitucionalmente como instrumento básico da política urbana. 
No campo local, essas promessas se materializariam no Plano Diretor com todo o seu arsenal de instrumentos urbanísticos. É o plano que deve dar o conteúdo da função social das cidades. Além disso, deve propiciar o debate dos temas centrais para o desenvolvimento urbano das cidades, como a promoção do acesso equitativo à terra urbanizada, daí a necessidade de qualificá-lo também como participativo.

Sem adentrar ao debate sobre sua viabilidade, ou não, a questão que se coloca é se esse sistema garante a legitimidade formal para os argumentos dos interessados na reversão do quadro de desigualdades. Sob a proposta da construção de cidades sustentáveis, o Estatuto da Cidade conceitua e relaciona um conjunto de princípios, diretrizes e instrumentos urbanísticos e jurídicos dos quais se espera, quando usados, certa eficácia contra a especulação imobiliária, induzindo a ocupação equânime da terra urbanizada.

O primeiro aspecto a ser lembrado diz respeito à necessidade de aproximar os instrumentos de indução ao desenvolvimento urbano ao processo de planejamento e na ação efetiva dos administradores no processo de implementação das políticas públicas.

Desde a aprovação do novo estatuto, o pensamento crítico da reforma urbana já alertava:

que estamos trabalhando com instrumentos que podem servir simultaneamente para controlar o uso do solo, influenciar o mercado de terras, arrecadar e redistribuir. Na forma como se aplica o instrumento pode estar enfatizada uma ou outra vertente; além disso, o desequilíbrio entre estas duas vertentes pode gerar, ao final do processo, uma demanda ainda maior de investimentos por parte do poder público. (ROLNIK, 2002, p. 141).

Mas a implantação desses instrumentos revela que os embates entre os diversos segmentos que atuam na política urbana ainda não foram efetivamente incorporados pelos agentes públicos, em franco favorecimento aos interesses dos proprietários das terras.

Um exemplo do impacto da ausência de estratégias eficientes de financiamento se dá pela análise de um instrumento clássico de arrecadação financeira, que é o IPTU. O tributo é um instrumento posto à disposição dos municípios desde a década de 1930, inicialmente como função meramente fiscal. Com o Estatuto da Cidade, sua função foi ampliada, com o objetivo de estimular o proprietário a cumprir a função social da propriedade, conforme o que for definido no Plano Diretor. Entretanto, como registra De Cesare (2007, p. 50): 
Enquanto o imposto sobre a propriedade imobiliária representa de 2,5\% a 3,5\% do Produto Interno Bruto (PIB) em países como Austrália, Canadá, Estados Unidos, Nova Zelândia e Reino Unido, sendo comum atingir 1\% do PIB mesmo onde o imposto foi recentemente instituído, como no caso da Polônia, o IPTU representa menos do que $0,5 \%$ do PIB no Brasil.

Ou seja, mesmo um instrumento básico, historicamente consolidado, com caráter predominantemente arrecadatório, ainda se ressente de efetividade na sua aplicação.

Ao destino que se verifica com o IPTU, somam-se as primeiras análises sobre o processo de implantação dos institutos, realizadas a partir de certo período de tempo, após a aprovação do Estatuto das Cidades. Em pesquisa coordenada pelo MCidades, em parceria com o Observatório das Metrópoles, os pesquisadores Biasotto e Oliveira (2011, p. 59) concluíram, no que diz respeito ao acesso à terra urbanizada, que:

o potencial dos instrumentos de intervenção no mercado de terras, de redistribuição da renda gerada pelo desenvolvimento urbano e da promoção da redução das desigualdades sociais no acesso à terra urbanizada e à cidade praticamente não foi aproveitado.

A pesquisa coordenada pelos autores indica que, embora os planos, em muitos casos, tenham incorporado o ideário do Estatuto das Cidades em seus termos mais genéricos, pouco avançaram no detalhamento da aplicação dos instrumentos que estavam previstos, permitindo inferir que no campo do acesso à terra a disputa assume mais complexidade, resultando ao mesmo tempo em maior difusão dos conceitos e o registro de derrotas sucessivas na efetivação dos princípios.

Outro exemplo concreto, trazido pelos citados autores $(2011$, p. 79$)$ é bastante revelador do estágio atual do processo de implantação dos instrumentos de acesso à terra:

O parcelamento, edificação ou utilização compulsórios, seguido do IPTU progressivo no tempo e da possibilidade de desapropriação com pagamentos em títulos da dívida pública - instrumentos definidos no art. 182 da Constituição Federal -, concentram as possibilidades mais efetivas de indução do desenvolvimento para áreas com boas condições de moradia, assim como, ao lado de outros instrumentos, da democratização do acesso à terra urbanizada. Aqui se agudizam, portanto, as dificuldades políticas de regulamentação dos instrumentos dos Planos Diretores, vide os conflitos previsíveis com proprietários e promotores fundiários - e, mais do que isso, toda a tradição patrimonialista brasileira. 
O que as primeiras interpretações sobre o processo de implantação dos planos diretores verificam é que estes não podem ser tomados como único instrumental a serviço da construção de cidades sustentáveis, pois, inclusive, o próprio campo institucional é insuficiente para realizar as transformações no espaço urbano suficientes para redirecionar o processo de privatização das cidades.

Há, como se vê, um abismo entre as promessas dos processos de elaboração de Plano Diretor e a realidade, pois, no mesmo campo em que os setores populares disputam suas propostas, também atuam outros setores, com outras estratégias.

É nesse cenário político e econômico em que os interesses financeiros se internacionalizam e constroem teias sofisticadas de relações com o capital nacional, como demonstra Fix, e onde as soluções dos temas relegadas ao campo local se encontram em situação de desvantagem, que a busca por terra urbanizada se desenvolve.

Portanto, o desafio de desatar o nó da terra continua como central, na agenda por reforma urbana, e a análise das políticas urbanas aplicadas recentemente contribui para compreender como esses limites são reforçados no próprio modelo de modernização conservadora estimulado na ação mais efetiva do Estado. Este é o intuito do próximo capítulo. 
4. A QUESTÃO DA TERRA NAS POLÍTICAS HABITACIONAIS 
A chamada crise urbana, representada pela falta dos elementos básicos de urbanidade que afeta a maioria das pessoas que vive nas cidades brasileiras, é o território sobre o qual este trabalho está assentado. Aos números alarmantes do déficit habitacional, somam-se as carências de saneamento, mobilidade; de acesso aos serviços urbanos e bens culturais, às oportunidades de trabalho e educação, em suma, a negação do direito à cidade.

\begin{abstract}
As condições de vida nas grandes cidades, principalmente nas metrópoles, têm se deteriorado a olhos vistos, configurando o que podemos chamar de crise urbana. De espaço de mobilidade social e lugar de acesso à diversidade cultural, melhores oportunidades de emprego e qualidade de vida, elas têm se tornado aglomerações, em grande parte depósito de pessoas, marcadas pela fragmentação, dualização, violência, poluição e degradação ambiental. (SANTOS JÚNIOR, 2007, p. 294).
\end{abstract}

A disputa pela terra urbanizada, a especulação imobiliária e a exclusão territorial da população mais pobre compõem a face mais dura da crise urbana. As políticas públicas habitacionais poderiam ser um contraponto a esse modelo, mas, no entanto, como se verá neste capítulo, acabam por reproduzi-lo e, por que não, aprofundá-lo. Bonduki (2008c, p. 3) ressalta a importância dessa questão.

A terra urbanizada, provida de serviços, equipamentos e infraestrutura, tornou-se cada vez mais cara, levando os que não tinham recursos a lugares cada vez mais distantes, precários e perigosos e à ocupação irregular. Este crescente processo mostra a ausência de uma política fundiária articulada com as políticas habitacional e urbana, nos diferentes níveis de governo no Brasil.

Aspecto comum das políticas habitacionais é que os arranjos financeiros e institucionais são priorizados e determinantes na concepção dos programas. O componente fundiário, para as moradias a serem produzidas, sempre foi tratado como secundário, ficando a cargo dos municípios, das companhias de habitação e demais agentes promotores, e especialmente, neste último período, das construtoras.

Além disso, na elaboração das políticas e programas habitacionais, as fontes de recursos e condições de financiamento determinam que produto, como e para quem a política será destinada, mesmo que contrarie, por exemplo, as próprias necessidades habitacionais. Prova disso é que tanto o BNH quanto os demais programas implementados pelo SFH atenderam ao déficit de forma inversamente proporcional, no que se refere às faixas de renda, excluindo os mais pobres, os que mais necessitam de políticas públicas, para 
os quais não sobrou opção a não ser a favela, o risco, a ocupação de áreas ambientalmente frágeis, ou o ônus excessivo de aluguel.

Os exemplos demonstram essa questão. Os antigos Institutos de Aposentadorias e Pensões (IAPs) adquiriram grandes bancos de terras que, apesar de também servirem para a produção habitacional, segundo Bonduki (1998), foram mais uma forma de investimento para preservar os recursos dos fundos previdenciários por meio de sua valorização imobiliária. No mesmo período, a Fundação da Casa Popular estimulava os municípios a doarem terrenos para a habitação, sem, no entanto, obter resultados expressivos.

Já o BNH delegava aos agentes promotores, públicos e privados, a viabilização de terrenos, que faziam parte do financiamento a ser concedido ao beneficiário final. Para os segmentos de mais baixa renda, as Cohabs municipais ou estaduais tinham a responsabilidade de adquirir terrenos, por meio de aquisição ou desapropriação, para contratar a construção dos empreendimentos. Como explica Silva (1997, p. 58-59),

\begin{abstract}
A escolha dos terrenos para programas populares do BNH decorre da falta de estratégias para redução de preços fundiários e das principais definições sobre a política habitacional. Os terrenos das Cohabs tinham que se adequar ao produto casa própria e ao financiamento sem subsídio. Para acomodar-se às condições de pagamento da população, esses produtos deveriam ter o menor custo possível, e nessa mesma lógica, o terreno deveria ter o menor preço possível. [...] Sem instrumentos para obter bons terrenos e preços menores, os terrenos adquiridos deveriam ser aqueles com o menor preço de mercado, geralmente os piores.
\end{abstract}

Silva (1997, p. 59) alerta ainda para a alta de preços de terrenos provocada pela disponibilidade de financiamentos e de como a política habitacional não se deteve diante do problema.

\begin{abstract}
Por outro lado, o SFH - tão autoritário para regulamentar o mercado financeiro não viu interesse em controlar o mercado fundiário. A alta de preços fundiários foi favorecida tanto pelos financiamentos aos programas populares como pelos destinados às faixas de renda média e alta. Como esta alta não prejudicava o desenvolvimento da indústria da construção e do mercado imobiliário enquanto houve financiamento, ela não foi verdadeiramente um problema para o sistema.
\end{abstract}

Uma forma de barateamento de custos foi a estratégia de "doação do terreno e/ou infraestrutura por parte dos estados e/ou municípios interessados na construção de conjuntos habitacionais" (ARRETCHE, 1990, p. 30), adotada a partir da defasagem detectada entre os custos de produção habitacional e a capacidade de endividamento do público-alvo. 
O BNH ainda tenta atuar mais fortemente sobre o tema, no final da década de 1970, com a criação do Departamento de Terras (Deter), mas obtém resultados pouco expressivos e enfrenta diversas dificuldades para a sua atuação (SILVA, 1997), especialmente relacionadas à localização dos terrenos.

A desapropriação torna-se um dos principais instrumentos para a aquisição de terras destinadas aos programas habitacionais. Apesar de ser um legítimo instrumento de política pública, sofre com avaliações fraudulentas, informações cartorárias débeis e cria uma indústria de ações indenizatórias, convertendo-se em excelente negócio para proprietários, advogados e investidores e gerando pesadas dívidas para estados e municípios, como relata a pesquisa desenvolvida por Maricato, E. ; Moreira, T. ; Haddad, E. ; Sandroni, P., sobre o tema.

As superindenizações precatoriais, provenientes das desapropriações, têm criado dificuldades pesando demasiadamente sobre o orçamento público e consequentemente limitando a implementação das políticas públicas urbanas, sejam elas relativas às áreas de habitação, de meio ambiente ou de vias públicas e rural, relativa à reforma agrária $(2000$, p. 5).

Com o fim do BNH e a restrição de financiamento ao setor público, que afeta diretamente as empresas públicas de habitação, outros modelos vão sendo adotados. Determinadas prefeituras, a partir do final da década de 1980, adotam iniciativas nesse sentido, como alteração em legislações municipais que definem o conceito de Zonas Especiais de Interesse Social (Zeis), criam diferenciais para a cobrança de Imposto Predial e Territorial Urbano (IPTU), como o IPTU progressivo e outros instrumentos urbanísticos, e viabilizam terrenos para sua política habitacional. Durante a gestão da prefeita Luiza Erundina, em São Paulo, por exemplo, 5 milhões de metros quadrados de terra (SILVA, 1997, p. 157) são viabilizados por iniciativa do órgão responsável pela política de HIS do município, por meio de aquisições e desapropriações.

Outra estratégia, desenvolvida pela CDHU, no Estado de São Paulo, com fonte própria de recursos, intensifica sua produção habitacional. Se, até o início dos anos 2000, a lógica era a aquisição, ou desapropriação, de terrenos ou, ainda, a doação, por parte de prefeituras, a partir daí, tem início o modelo da "empreitada integral", quando a CDHU passa a licitar não apenas a construção do empreendimento, mas o "pacote completo", com 
terreno, infraestrutura e edificação, indicando a quantidade de unidades e o município desejado. Os argumentos favoráveis a esse modelo giram em torno da agilidade, já que os processos de desapropriação são longos e com certo grau de imprevisibilidade.

Esse também é o modelo adotado pelo Programa de Arrendamento Residencial (PAR), criado pela Lei 10.188/2001, que adquiria unidades a serem construídas, em construção, concluídas a recuperar ou reformar, para o programa. Nesse modelo, cabia à construtora trazer a proposta com terreno viabilizado, que poderia ser comprado com recursos do programa. O poder público, nessa perspectiva, isentava-se totalmente da decisão e da viabilização dos terrenos, cabendo às empresas, dentro das regras de mercado, conseguir terrenos desimpedidos para apresentar ao governo. Como se verá, esse modelo inspira o que veio a ser o programa MCMV.

Em 2004, o Conselho Nacional das Cidades aprova a Política Nacional de Habitação, que

destaca o papel estratégico da política fundiária, a ser implementada mediante aplicação dos instrumentos do Estatuto da Cidade, tais como o parcelamento e edificação compulsórios e o IPTU progressivo, o solo criado, o direito de superfície e o estabelecimento de Zeis, que podem interferir na lógica de formação de preços no mercado imobiliário. (SNH/MCIDADES, 2009, p.13).

Ainda que traga o tema à agenda da política habitacional, novamente, a política fundiária para a produção habitacional é delegada à ação dos municípios, sem definir mecanismos ou critérios da política federal.

\subsection{Os conjuntos habitacionais}

O resultado dessas políticas tem sido, na maioria das vezes, a construção de conjuntos habitacionais distantes da malha urbana, sem acesso ou com precária infraestrutura. Como afirmam Rolnik, Cymbalista e Nakano (2008, p. 7): 
automóvel particular. No epicentro deste modelo - e sua interface com a questão habitacional - está a questão do solo urbano.

Moradia popular produzida com financiamento público vira sinônimo de conjuntos habitacionais com baixa qualidade de projeto, construção e, principalmente, inserção urbana. Via de regra, conjunto habitacional fica "longe da cidade", na expressão de seus moradores. Nahoum (2011, p. 77) denomina esse fenômeno de "déficit de localização". A distância, portanto, não é medida em metros, mas no que os afasta do acesso às oportunidades, aos serviços, enfim, dos direitos. Exemplo disso, a Cidade Tiradentes, complexo de conjuntos habitacionais que abriga mais de 40 mil famílias, só recebe em 2012 seu primeiro equipamento cultural público, 28 anos depois de sua implantação.

Essa tipologia de conjuntos, marcada pela mesmice arquitetônica e a lógica de que primeiro chegam as casas e depois chega a cidade, passa a ser adotada como modelo único. O aproveitamento de pequenos vazios, a reabilitação de edifícios ociosos e a aquisição de unidades usadas vagas na cidade praticamente são descartadas como alternativas nos programas de produção habitacional.

Para os setores de menor renda, a alternativa do loteamento ou conjunto
habitacional (lotes, apartamentos ou casas próprias) consagrou-se como o modelo
hegemônico, justificado pelo impacto do preço dos terrenos mais baixos na franja
externa das cidades. Todo o desenho da política habitacional a partir daí -
praticada por agentes públicos ou pelo setor privado - seguiu essa mesma lógica.
(PLANHAB, 2009, 41).

A moradia, nesse contexto, restringe-se à sua função de abrigo e "reprodutiva da força de trabalho", deixando de lado suas dimensões produtiva, social, cultural e espiritual, na expressão de Ortiz (2011, p. 21). A distância e a baixa densidade desses conjuntos, no lugar de representarem economia de recursos para a sua produção, provocam impacto no território, enorme custo de manutenção e incalculável custo social. O PlanHab (2009, p. 65) também alerta:

Ao adicionarmos aos custos da infraestrutura o custo de equipamentos e serviços públicos, como educação, saúde, segurança e lazer, teremos um impacto ainda maior, decorrente da baixa densidade. Sem contar que a proximidade com o comércio e as demais fontes de trabalho aumentam o poder aquisitivo da população e a qualidade de vida, pois são evitados gastos de tempo e de dinheiro em transporte. 
Ao lado de questionável sustentabilidade social, também se coloca em questão a sustentabilidade ambiental desses empreendimentos, ao exigirem deslocamentos diários de seus moradores para o trabalho e demais necessidades de equipamentos, realizados geralmente em transporte público poluente, a diesel e sobre pneus, exigindo uma frota cada vez maior, mais infraestrutura viária e impermeabilização do solo. Além disso, há exemplos de empreendimentos construídos em áreas ambientalmente frágeis, inclusive infringindo a legislação ambiental.

Característica desse modelo é a política voltada para a produção da casa própria e nova, com algumas exceções, como políticas locais ${ }^{87}$ ou PAR $^{88}$. Segundo Arretche (1990, p. 30), essa opção fundamenta-se em dois aspectos: um de caráter ideológico - transformar trabalhadores em proprietários os torna defensores da estabilidade social e contrários a mobilizações que coloquem em risco o patrimônio adquirido - e outro de caráter econômico - mais do que uma política social, o financiamento da construção de moradias estimula a cadeia da construção civil e do setor imobiliário. Com isso, qualquer outra forma de acesso à moradia seria descartada, tanto políticas de aluguel, desenvolvidas sobretudo em experiências europeias de locação social, quanto as formas cooperativistas, comuns sobretudo nos países nórdicos e no Uruguai.

A maioria dos recursos, orçamentários ou não, são destinados à produção de unidades novas. A reabilitação de edifícios ociosos, ou as melhorias habitacionais em moradias autoconstruídas, nunca foi priorizada e foi mantida como projetos-piloto pontuais ${ }^{89}$.

Marca dessas políticas é a separação do planejamento urbanístico da estratégia da produção habitacional - o primeiro destinado à cidade formal e à sua reprodução dentro da lógica do capital e, a outra, como política residual e compensatória. No início dos anos 2000, o projeto Moradia dá ênfase à

\footnotetext{
87 Um dos exemplos vem da Prefeitura de São Paulo que, no início dos anos 2000, construiu alguns conjuntos para locação social, como alternativa para famílias em situação de maior vulnerabilidade e que não poderiam arcar com financiamento habitacional.

88 O PAR arrenda as moradias adquiridas pelo FAR por um período de 15 anos, e que podem ser alienadas aos arrendatários no final desse período. Ou seja, com uma modalidade distinta, o programa ainda tem como objetivo final a transferência da propriedade.

${ }^{89}$ Também no PAR são feitas algumas reabilitações de edifícios em áreas centrais, sempre por proposição de movimentos sociais, após ocupações e pressão junto ao poder público.
} 
necessidade de aprovação do Estatuto da Cidade para facilitar e baratear o acesso à terra, combatendo a especulação com imóveis ociosos. A noção de que a questão da habitação não podia ser enfrentada sem uma forte intervenção no mercado fundiário e de modo articulado com a questão urbana (...) e ratificou a concepção de que o problema da moradia não se resolvia apenas com a construção de casinhas, mas era necessário enfrentar também a questão urbana e fundiária. (BONDUKI, 2009, p. 2).

A Política Nacional de Habitação, aprovada pelo Conselho Nacional das Cidades, em 2004, busca colocar em cena as propostas do projeto Moradia. No entanto, apesar de afirmar que sua implementação "exige uma articulação com a política urbana, particularmente com a política fundiária, que pode criar as condições de oferta de terra urbanizada e barateamento de imóveis e facilitar a produção de novas moradias" ${ }^{\prime 90}$, o tema foi relegado a segundo plano e no âmbito das políticas de habitação nenhuma estratégia concreta é definida.

Para Rolnik, Cymbalista e Nakano (2008, p. 44), a "própria natureza dos programas habitacionais - mais voltados para fomentar a indústria da construção do que para o atendimento das necessidades habitacionais contribui para este descolamento", pois é mais fácil construir onde há menos regulação do solo. O resultado reproduz a lógica perversa da expulsão dos mais pobres para os piores lugares, agora, porém, financiado com recursos públicos.

\subsection{Terra para Moradia nos Planos Diretores}

Além das questões já elencadas, é importante destacar que o MCMV ocorre no momento imediatamente posterior ao da maioria dos municípios, para os quais o programa foi dirigido (com mais de 100 mil habitantes), ter elaborado seus planos diretores, pósaprovação do Estatuto da Cidade ${ }^{91}$ e seus planos locais de habitação (a partir de 2006).

\footnotetext{
${ }^{90}$ MCIDADES. Política nacional de habitação. 2004, p. 94.

${ }^{91}$ O Estatuto da Cidade, em 2001, regulamenta o dispositivo constitucional previsto no artigo 182, tornando obrigatória a elaboração de planos diretores nos municípios maiores de 20 mil habitantes, e dá um prazo de 5 anos para a sua conclusão.
} 
Nesse sentido, existe uma expectativa em verificar quanto esses instrumentos podem ter apoiado ou não a implementação do programa.

Esse tema recebe atenção no decorrer da elaboração dos planos diretores participativos. Além de exigir a participação popular nesses processos, é constatada também a mobilização de diversos grupos diretamente ligados às lutas pela moradia, com o objetivo de inserir instrumentos que viabilizassem o acesso à terra urbanizada para a população de baixa renda e pelo reconhecimento das áreas já ocupadas.

Esses grupos defendem a utilização dos instrumentos urbanísticos para garantir acesso à terra urbanizada de qualidade, pela população excluída do mercado de terras e moradia, e que os instrumentos de planejamento urbano devem voltar-se a essa finalidade. O FNRU e suas entidades filiadas, além de outros agentes sociais, empreendem diversas ações no sentido de capacitar e mobilizar a sociedade para participar e trazer sua perspectiva para a implementação do Estatuto da Cidade e a elaboração dos Planos Diretores Participativos. Em julho de 2002, o FNRU aprova a Carta para Implementação do Estatuto da Cidade, no Encontro Nacional pelo Direito à Cidade, que destacava a importância da difusão da nova lei e as diretrizes a serem consideradas.

São realizados inúmeros seminários e publicadas cartilhas populares, material informativo para a sociedade civil, gestores municipais e Legislativo ${ }^{92}$, além de extensa produção acadêmica. É possível afirmar que, nos primeiros anos da década, a pauta do planejamento participativo teve seu auge nas discussões e ações desse conjunto de atores.

A evidência de que a falta de políticas fundiárias direcionadas à população de baixa renda inviabiliza a efetivação de uma política de habitação mais abrangente e efetiva, torna a agenda da reforma urbana cada vez mais presente na pauta dos movimentos de moradia. Nesse processo de difusão e sensibilização, ocorrido após a sanção do Estatuto da Cidade, o tema do acesso à terra urbanizada esteve sempre presente. Os exemplos a seguir trazem trechos de material utilizado nessa mobilização e capacitação e, principalmente,

\footnotetext{
${ }^{92}$ Destaca-se o Estatuto da Cidade: Guia para Implementação pelos Municípios e Cidadãos, publicado pelo Instituto Pólis e a Comissão de Desenvolvimento Urbano da Câmara dos Deputados, em 2001, e o Kit das Cidades, em 2002, também editado pelo Instituto Pólis, como instrumentos de difusão do Estatuto da Cidade.
} 
fundamentam a elaboração de propostas de incidência política desses movimentos nos níveis local e nacional.

O que é Zeis?

O nome Zeis quer dizer Zonas Especiais de Interesse Social. Elas são áreas da cidade que fica destinada pelo Plano Diretor para abrigar moradia popular.

As Zeis servem para:

- reservar terrenos ou prédios vazios para moradia popular em áreas onde já existe boa infraestrutura. Por exemplo, uma propriedade subutilizada no Centro da cidade pode virar uma Zeis;

- facilitar a regularização de áreas ocupadas. Quando uma área ocupada vira Zeis, seus moradores conseguem regularizar sua moradia de forma mais rápida. E também fica mais fácil lutar por melhorias para aquela região.

Mas devemos estar atentos no momento de marcá-las no mapa! O importante é que existam Zeis nas partes mais centrais, equipadas e providas de infraestrutura. Isso vai evitar que a população seja expulsa para os piores locais e pode induzir a ocupação das melhores partes da cidade pelas pessoas que precisam de moradia. Assim, ocupamos a cidade de forma mais equilibrada..$^{93}$

Figura 29 - Cartilha Vamos Mudar Nossas Cidades?

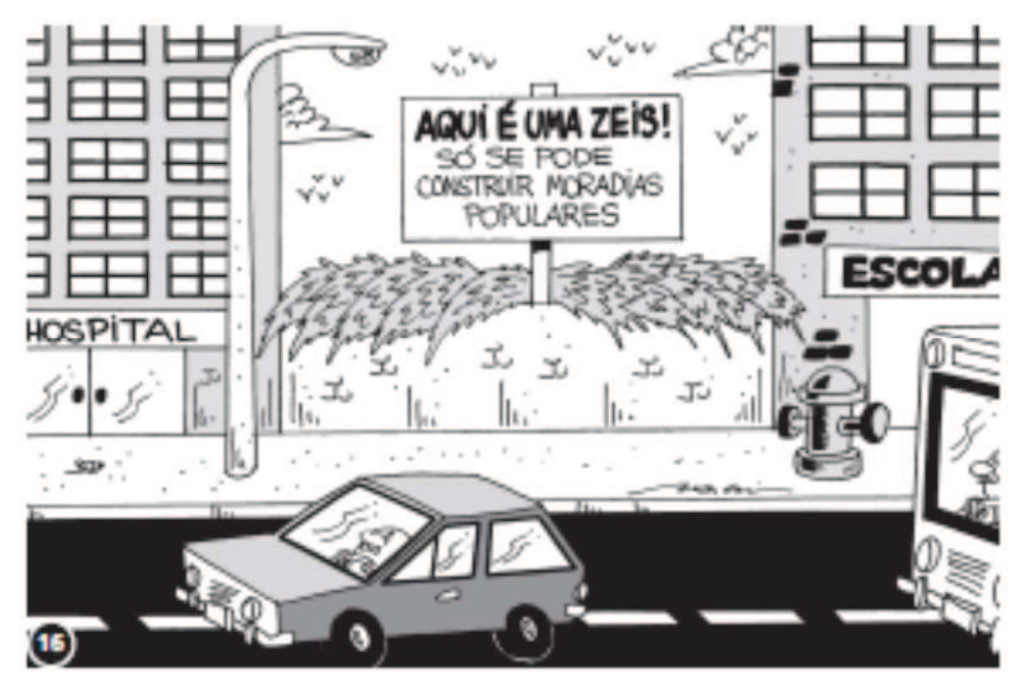

Fonte: Instituto Pólis, p. 16.

A campanha nacional Plano Diretor Participativo: Cidade de Todos, empreendida pela Secretaria Nacional de Programas Urbanos do MCidades, em conjunto com o Conselho Nacional das Cidades, entre 2005 e 2007, dá ênfase ao tema fundiário. A campanha atua em todo o País, constituindo 26 núcleos estaduais, compostos por diversos atores sociais, que

\footnotetext{
${ }_{93}^{93}$ INSTITUTO PÓLIS. Plano diretor: participar é um direito. 2005, p. 10.
} 
trabalham na apropriação dos preceitos e valores previstos no Estatuto das Cidades e ampliação da participação da sociedade na elaboração dos planos. Nesse contexto, o Conselho das Cidades inclui, como conteúdo mínimo dos planos diretores, questões dirigidas ao tema acesso à terra urbanizada, em sua Resolução 34/2005:

Art. 2ำ As funções sociais da cidade e da propriedade urbana serão definidas a partir da destinação de cada porção do território do município bem como da identificação dos imóveis não edificados, subutilizados e não utilizados, no caso de sua existência, de forma a garantir:

(...)

IV - terra urbanizada para todos os segmentos sociais, especialmente visando à proteção do direito à moradia da população de baixa renda e das populações tradicionais;

(...)

Art. 5․ A instituição das Zonas Especiais, considerando o interesse local, deverá:

I - destinar áreas para assentamentos e empreendimentos urbanos e rurais de interesse social;

Nesse processo, os movimentos ligados às lutas pela moradia também se mobilizam, com o objetivo de inserir instrumentos que viabilizassem o acesso à terra urbanizada para a população de baixa renda e pelo reconhecimento das áreas já ocupadas, combinando a ação direta com a mobilização institucional. Santos Jr. $(2008$, p. 10) destaca que

As organizações populares têm participado do processo de elaboração dos planos diretores, o que pode ser evidenciado pela composição da coordenação nacional da campanha, no âmbito federal, como também pela análise das organizações que integram os núcleos estaduais da mesma e que participaram das atividades de capacitação que foram promovidas. No entanto, isso não implica em dizer que essas organizações, das quais os Sem Teto são uma das expressões mais relevantes, estejam atuando nesse processo em detrimento de outras formas de luta, tais como as ocupações de imóveis vazios, atos públicos e etc. Ao contrário, temos fortes razões, tomando em conta o monitoramento dos conflitos urbanos realizado pelo Fórum Nacional de Reforma Urbana, que essas manifestações têm aumentado em todo país. Tal fato é um indício que essas organizações não estariam tomando parte do processo, enganadas pela "ilusão do plano diretor", mas que, pelo menos suas principais lideranças, percebem que esse é um espaço que deve ser ocupado (2008, p.10).

Os resultados dessa ação são avaliados pela Pesquisa Nacional dos Planos Diretores Participativos, desenvolvida pelo MCidades e o Observatório das Metrópoles, que formou uma Rede Nacional de Avaliação e Capacitação para a Implementação dos Planos Diretores Participativos. 
Oliveira e Biasotto (2011, p. 60) destacam que a maioria dos planos adota a função social da propriedade como diretriz, assim como o acesso à terra urbanizada. De modo geral, o tema aparece nos princípios, objetivos e diretrizes, mas poucos constituíram instrumentos concretos para a sua efetivação, nem fazem relação com as políticas que serão implementadas.

Um tema constante nos planos é a ampliação dos limites do perímetro urbano e criação de zonas de "expansão urbana", porém, em raras ocasiões, percebe-se a previsão de instrumentos para recuperar a valorização decorrente dessa ação, atos de planejamento nesses territórios ou a vinculação a intervenções de interesse social. Oliveira e Biasotto (2011) também notam a ausência de critérios para essas ampliações e posteriores revisões. Ou seja, esses dispositivos parecem atender muito mais aos interesses especulativos do que às necessidades do município, especialmente da população de baixa renda.

As Zeis são mencionadas na maioria dos planos, segundo a pesquisa, porém nem sempre acompanhadas da devida demarcação de seus perímetros e poucas tiveram, dentro do próprio plano, detalhada a regulamentação de seu uso, deixando para leis complementares que nem sempre chegaram a ser elaboradas ou aprovadas. Quando da demarcação das Zeis, a maioria dos municípios privilegiou as áreas já ocupadas com a finalidade de regularização.

As Zeis são instrumentos que demarcam, no zoneamento da cidade, áreas para a população de menor renda e podem ser utilizadas em áreas já ocupadas, favelas, ocupações, assentamentos populares com algum tipo de irregularidade - chamadas de Zeis de Regularização -, ou em áreas vazias, a serem reservadas para a produção de HIS. Rolnik e Santoro (2012, p. 1) destacam o papel das Zeis em

intervir sobre as regras que definem que o uso e a ocupação do solo poderia operar no sentido de ampliar o acesso à terra para populações que não encontram esta possibilidade no mercado e de acordo com as regras atuais do zoneamento. A possibilidade de utilização das Zeis para reservar espaços para habitação de interesse social no ordenamento territorial das cidades invertendo a lógica predominante do zoneamento como reserva de terra e proteção de valores de solo para os mercados de média e alta renda deveria colaborar também, em tese, para uma boa utilização de áreas subutilizadas e vazias mais centrais. 
Nesse sentido, as Zeis podem ser utilizadas como instrumento de resistência às remoções, e também como forma de viabilizar programas de investimento urbano, especialmente de habitação, de forma combinada e que reverta a lógica da expansão periférica (ROLNIK e SANTORO, 2012).

As Zeis de áreas vazias para a produção de HIS foi um instrumento bem menos utilizado nos planos diretores, e não há um levantamento preciso sobre o volume de terra vazia demarcada como Zeis nos planos diretores e leis de uso e ocupação do solo municipais e sua relação com o déficit habitacional, ou seja, se a quantidade de terra poderia atender à necessidade, mas, de modo geral, se constata a sua insuficiência.

Além da demarcação territorial de Zeis, também é necessário que a legislação municipal delimite seus parâmetros de utilização e aprovação de empreendimentos. Experiências de limitação da quantidade de metros quadrados, número de banheiros, ou vagas de garagem não garantem, necessariamente, a destinação dos imóveis à faixa de renda desejada ${ }^{94}$. Alguns outros condicionantes têm sido utilizados, como a proibição de remembramento, limitação de preço máximo da unidade habitacional, definição de agentes autorizados para atuar nessas áreas ou de vinculação a programa habitacional (SNH/MCIDADES, 2009).

Também não se verificou a incidência desse instrumento em áreas centrais, vazios urbanos em áreas consolidadas, sítios históricos e se esses instrumentos efetivamente têm tido incidência na melhor localização dos conjuntos habitacionais populares.

\footnotetext{
Em linhas gerais, o zoneamento foi pouco utilizado para garantir incremento no acesso à terra urbanizada e bem localizada e à moradia; a definição de Zeis em áreas vazias também foi pouco adotada, com baixa aplicabilidade e pequena incidência de delimitação espacial; a captação de recursos para fins habitacionais se mostra acanhada. (CARDOSO e SILVEIRA, 2011, p. 122).
}

A pesquisa indica ainda que a maioria dos planos também cita instrumentos de indução de desenvolvimento urbano e recuperação de mais-valias fundiárias, como parcelamento e edificação compulsórios, direito de preempção, entre outros, mas foram

\footnotetext{
${ }^{94}$ Em São Paulo, os imóveis produzidos em Zeis para HIS limitam a área do imóvel em 50 metros quadrados, com um banheiro, e impedem a construção de garagem coberta. Nem por isso, áreas demarcadas como Zeis e com imóveis com as características citadas deixaram de ser adquiridos por interessados com faixas maiores de renda.
} 
observados alguns problemas na sua efetivação, como a delimitação e regulamentação desses instrumentos relegada a legislação complementar e também a sua não vinculação a estratégias de política habitacional, nem à viabilização da utilização das ZEIS. Ainda se destaca enorme rol de exceções para a utilização dos instrumentos, demonstrando a força de interesses locais e pontuais e dificultando a democratização do acesso à terra.

Ainda quando os instrumentos são utilizados, não há garantia de que não serão apropriados pela especulação ou gerarão efeitos contrários aos pretendidos, especialmente quando são utilizados de forma isolada, sem articulação com os demais instrumentos de política urbana e investimentos na cidade. A simples flexibilização de exigências e parâmetros não garante, necessariamente, a queda do preço da terra. Como no exemplo abaixo, da cidade de Maringá, sobre as alterações de parâmetros urbanísticos:

\begin{abstract}
A primeira medida foi a liberação de lotes de alta densidade habitacional na zona de transição entre o perímetro urbano e a zona rural. A segunda foi reduzir de $30 \%$ para $10 \%$ a área do loteamento que deve ser doada para habitação popular, no caso de empreendimentos na zona rural, mas situados no limite com o perímetro urbano. Para a socióloga Ana Lúcia Rodrigues, coordenadora do núcleo de estudos Observatório das Metrópoles, as ações da prefeitura tiveram efeito contrário ao anunciado. 'Hoje o terreno em Maringá está mais valorizado do que no final do ano passado. A prefeitura liberou os loteamentos em áreas que não podiam ser loteadas. O preço desses terrenos subiu e valorizou os terrenos que agora estão melhor situados em relação a essas novas áreas.'

(...) Segundo Ana Lúcia, a valorização do preço da terra poderia ter sido contido se há três anos a prefeitura tivesse implantado o IPTU progressivo e o parcelamento compulsório, conforme o previsto no Plano Diretor da cidade ${ }^{95}$.
\end{abstract}

Cardoso e Silveira" chamam essa desarticulação de "ausência de estratégias socioambientais" pois, apesar de incluírem em seu plano diretor uma série de preocupações com o acesso ao solo urbanizado, não se articulam com planos, projetos e, principalmente, definições orçamentárias de ações.

Além disso, é fundamental a articulação desses instrumentos com os investimentos no MCMV. Sobre essa questão, Bonduki (2009) aponta a importância dos municípios.

É importante ressaltar que são limitadas as possibilidades do governo federal quanto a garantir uma localização adequada dos projetos se os municípios não estiverem dispostos a isso. (...). O PlanHab propôs incentivar, com prioridade no

\footnotetext{
95 Valor dos terrenos inibe 'Minha Casa, Minha Vida' em Maringá. Disponível em: (http://www.maringaimoveis.com.br/Noticias/Index/234743>. Acesso em:10.jan.2013 96 PDP, 2011, p.122.
} 
acesso aos recursos, os municípios que adotassem políticas fundiárias e urbanas corretas, como a instituição do imposto progressivo para combater os imóveis ociosos e subutilizados, lembrando que quase 2 mil municípios formularam planos diretores e, na sua grande maioria, não puseram em prática instrumentos para combater a especulação imobiliária ${ }^{97}$.

A competência do município, no entanto, não isenta que a política nacional e seus investimentos estimulem e, mais que isso, condicionem sua destinação a boas práticas territoriais.

\subsection{Estratégias urbanas e fundiárias no PlanHab}

Após aprovação da Política Nacional de Habitação e a promulgação da Lei do Sistema Nacional de Habitação de Interesse Social (Lei 11.124/2005), tem início a elaboração do Plano Nacional de Habitação (PlanHab). A questão da terra para habitação obteve destaque e foi um dos quatro eixos do plano, que propunha combinar estratégias dentro da política habitacional e articulá-la com outras políticas de desenvolvimento urbano.

O plano foi elaborado entre 2007 e 2008, época marcada pela recente abertura de capital de empresas do setor imobiliário, que investiram justamente na aquisição de terrenos e no lançamento de empreendimentos imobiliários, para o que as empresas classificam como "segmento econômico", ou seja, famílias de classe média e média baixa, com condições de assumir financiamentos de longo prazo, como demonstra Fix (2011, p. 138).

As empresas que pretendiam abrir capital e aquelas já listadas na bolsa passaram a aumentar significativamente o estoque de terras, em parte como modo de convencer os investidores de que seria possível conseguir o Valor Geral de Vendas (VGV) prometido nas ofertas de ações. Em consequência, a competição entre as empresas gerou o aumento do preço do solo, motivando a busca por terrenos mais distantes dos principais centros urbanos ou em outros municípios e estados.

Esse processo é parcialmente interrompido pela crise econômica mundial, e retomado pelo lançamento do programa MCMV.

97 BONDUKI, Nabil. Do projeto moradia ao minha casa minha vida. Teoria e Debate, n. 82, maio/jun. 2009, p. 13 
Já durante a elaboração do plano, verifica-se que qualquer política seria malograda, se não se ocupasse do tema da terra e tivesse mecanismos para conter a especulação, como afirma Bonduki (2008b, p. 2):

(...) o fundamental é controlar o preço da terra - o que deveria ter sido previsto nos planos diretores - e melhorar a produtividade da construção civil. Se ocorrer um boom imobiliário sem que haja uma adequada regulação do mercado de terras e sem preparar a cadeia da construção civil para uma produção massiva, o custo da habitação irá se elevar, afetando a possibilidade de ampliação da produção de habitação social. Se nada ocorrer, o crédito farto gerará um boom imobiliário, mas, novamente, os setores de baixa renda ficarão de fora, reproduzindo-se o tradicional processo de exclusão territorial e o desastre urbano e ambiental que tem sido uma marca do desenvolvimento urbano brasileiro.

O plano, nesse eixo, traz entre seus objetivos o binômio acesso à terra urbanizada para produção habitacional e a regularização de áreas já ocupadas para garantir e melhorar a permanência de seus moradores. Dentre as seis estratégias propostas apresentadas, algumas se relacionam com a ação dos municípios, mas parte delas necessita de ação do governo federal e do Legislativo.

\section{Objetivos gerais}

Garantir acesso à terra urbanizada, legalizada e bem localizada, para a provisão de HIS (unidades prontas ou lotes) na escala exigida pelas metas do PlanHab.

Regularizar os assentamentos informais, garantindo a permanência dos moradores de baixa renda.

\section{Estratégias}

1. Incorporar instrumentos de manejo do solo urbano e de regularização fundiária de assentamentos precários e informais no PL 3.057/2000;

2. Estimular os municípios a adotarem instrumentos para facilitar o acesso à terra urbanizada, utilizando o Índice de Capacidade Institucional Habitacional e Gestão Urbana;

3. Dimensionar a terra necessária para a produção de HIS e integrar a regularização fundiária nos Planos Locais de Habitação de Interesse Social;

4. Produzir e regularizar a habitação de interesse social nos imóveis da União;

5. Criar o Subsídio Localização para viabilizar a produção e a reabilitação de HIS em áreas históricas, centrais e consolidadas;

6. Aplicar os instrumentos de regularização fundiária previstos no Estatuto da Cidade e na Medida Provisória 2.220/2001. ${ }^{98}$

A primeira estratégia relaciona-se à revisão da Lei do Parcelamento do Solo (Lei 6766/1979), que se encontrava no Congresso Nacional e propõe algumas emendas no

\footnotetext{
98 PlanHab, p. 120.
} 
sentido de aumentar a oferta de lotes urbanizados e facilitar a regularização fundiária de áreas ocupadas. A maioria das propostas relacionadas com a regularização fundiária foi incluída pelo governo na Medida Provisória 459/2009, que cria o MCMV e se converte na Lei 11.977/2009. Essa lei define a regularização de interesse social, com parâmetros e procedimentos específicos; regulamenta a competência municipal e adapta os instrumentos da demarcação urbanística e legitimação de posse para a finalidade social, com o objetivo de trazer regularidade, inclusive, às obras do Plano de Aceleração do Crescimento (PAC), em assentamentos precários. A revisão da lei de parcelamento e as propostas que visam a ampliação do acesso à terra não foram aprovadas até o momento.

Para ampliar a quantidade de lotes destinados à habitação social, o plano propõe a doação de percentual obrigatório de terra em novos parcelamentos para HIS, que seriam empreendidos pelo poder público, ou por agentes privados, mas vinculados a um programa habitacional para baixa renda. Já existem iniciativas municipais nesse sentido, em implementação, como na cidade de Goiânia. Propõe, ainda, a exigência de o município elaborar Plano de Expansão Urbana, quando da extensão do perímetro urbano, prevendo a infraestrutura e os equipamentos necessários, demarcando áreas para HIS e evitando o parcelamento gleba a gleba. No campo do licenciamento, propõe integrar a legislação ambiental e urbanística, a fim de evitar os conflitos nessas duas áreas e contemplar a diversidade do território brasileiro, evitando os modelos que não dialogam com essa diversidade.

Também como estratégia, o PlanHab recupera os avanços recentes da legislação urbanística brasileira, estimulando os municípios a aplicá-los. Esse incentivo dar-se-á por uma pontuação no Índice de Capacidade Institucional e Gestão Urbana, viabilizando o acesso a mais recursos do FNHIS para os municípios que aplicam instrumentos como Zeis, direito de superfície, IPTU progressivo, entre outros, que favorecessem a ampliação de território para HIS.

Para o PlanHab, os PLHIS devem elencar os instrumentos necessários, e também dimensionar a quantidade de terra e infraestrutura necessárias para as necessidades habitacionais dos municípios, diferenciadas por produtos habitacionais e faixas de renda. 0 PlanHab recomenda que, a partir desse diagnóstico, sejam elaboradas as políticas fundiárias 
e leis de uso e ocupação do solo municipais, como a criação de Zeis, para que possam impactar no mercado fundiário.

A utilização de imóveis públicos para HIS, especialmente da União e de empresas e autarquias públicas, também é apontada como estratégia, fazendo com que esses imóveis também cumpram a sua função social. Para isso, é necessário o mapeamento dos imóveis e seu desembaraço, a simplificação da destinação, a utilização de instrumentos como a Concessão do Direito Real de Uso (CDRU) e ações no sentido de enfrentar entraves de caráter registral das terras públicas. A Secretaria do Patrimônio da União (SPU) criou em 2008, o Grupo de Trabalho Nacional para Programas de Provisão Habitacional de Interesse Social, no âmbito do Conselho Nacional das Cidades, com essa finalidade. Esse grupo e os grupos estaduais também criados têm trabalhado com imóveis do patrimônio da União e, mais recentemente, com imóveis da antiga Rede Ferroviária Federal. Embora alguns entraves já tenham sido superados, como a aceitação da CDRU nos financiamentos do programa $\mathrm{MCMV}^{99}$, a destinação de imóveis para HIS até agora tem sido residual e enfrenta muitos entraves burocráticos e lentidão.

A proposta de criar um "subsídio localização" tem como objetivo reverter a lógica de que os conjuntos de HIS sempre estão nas zonas mais periféricas da cidade. Esse mecanismo favorece a construção de moradia social em áreas centrais degradadas, centros históricos, áreas desindustrializadas, com infraestrutura disponível, e próximas a regiões com oportunidades de emprego, de forma a reduzir a necessidade de deslocamentos e utilizando redes muitas vezes ociosas. Nas áreas históricas, esse subsídio pode somar-se a recursos de preservação de patrimônio, garantindo também a ocupação, o uso e cuidado desses imóveis.

No entanto, poucas propostas, contidas no Eixo de Estratégias Urbanas e Fundiárias do PLANHAB foram implantadas, como se verá a seguir.

\footnotetext{
${ }^{99}$ NO FAR e FDS, a CDRU já vinha sendo aceita desde a concepção do programa. No FGTS, embora já houvesse previsão legal, foi necessária uma resolução do conselho curador, em 2011, para a contratação do primeiro empreendimento com CDRU, o Riacho Fundo II, em Brasília/DF.
} 


\subsection{Terra no Minha Casa Minha Vida}

Por ocasião do lançamento do programa MCMV, em março de 2009, vários setores alertaram para o fato de que o tema fundiário não estava sendo tratado de maneira adequada e que os acúmulos da sociedade advindos da luta pela reforma urbana, das Conferências das Cidades e do próprio PlanHab não estavam sendo considerados. Em reunião com a então ministra da Casa Civil, Dilma Roussef, algumas semanas antes do lançamento do programa, os movimentos populares apresentaram suas preocupações sobre a questão da terra no programa:

A primeira questão que foi levantada foi a ausência de uma estratégia fundiária para a construção dessas 1 milhão de casas. Foi lembrado que já temos uma política nacional de habitação aprovada, além de marcos legais importantes. Não queremos repetir os erros do passado, com a construção de conjuntos habitacionais longe das cidades, servindo somente à especulação imobiliária e não construindo qualidade de vida nessas intervenções. Lembramos da necessidade de atrelar os investimentos aos planos diretores dos municípios e também da necessidade de aprovação de medidas mais ousadas, no PL 3057, como a que destina $10 \%$ dos novos loteamentos para HIS ${ }^{100}$.

Após a apresentação do programa MCMV e durante a aprovação no Congresso Nacional, várias propostas foram encaminhadas ao governo federal, algumas por meio de emendas à Medida Provisória e outras por documentos e manifestos de entidades e movimentos sociais, como o do FNRU:

O FNRU entende, ainda, que a prioridade na alocação de recursos deva ser para as áreas centrais e infraestruturadas dos centros urbanos, com parâmetros diferenciados de financiamento nestes casos, de modo que os setores privado e público priorizem a implantação de moradias em locais com serviços de saúde, educação, transporte, empregos e oportunidades de desenvolvimento humano, revertendo a tendência atual de concentrar os empreendimentos de moradia popular em áreas distantes e sem infraestrutura urbana e social e provocando o aumento da segregação e da violência urbana ${ }^{101}$.

O deputado federal Zezéu Ribeiro (PT-BA), coordenador da Frente Parlamentar pela Reforma Urbana, apresenta a emenda, não aprovada, que priorizaria, na distribuição das unidades do programa, os municípios que doassem terrenos localizados em área urbana

\footnotetext{
100 UNMP. Relato de reunião com a ministra Dilma Roussef em 3/3/2009. Brasília, 2009.

${ }^{101}$ FNRU. Boletim a reforma urbana e o programa Minha Casa Minha Vida. 2009.
} 
consolidada para a implementação do programa, desonerassem tributos para as construções de HIS, e implementassem os instrumentos do Estatuto da Cidade, visando ao controle da retenção de áreas urbanas ociosas ${ }^{102}$.

No programa MCMV, a disponibilização de terrenos para os empreendimentos é de competência dos agentes promotores, em mais de $85 \%$ dos casos, empresas construtoras e, na minoria, entidades, cooperativas e prefeituras ${ }^{103}$. A princípio, o custo do terreno está incluído no valor do investimento. O poder público é chamado a contribuir de diversas formas, com o apoio institucional ou o aporte financeiro, de serviços ou bens.

Os municípios também são chamados a apoiar o programa com a destinação de terrenos públicos, que deverão ser doados ou cedidos para o empreendimento, mas essa não é uma condição restritiva para a aprovação ou implementação do projeto. O decreto que regulamenta o MCMV 2 aponta critérios de priorização para os empreendimentos relacionados com a inserção urbana e a aplicação de instrumentos do Estatuto da Cidade, mas tais mecanismos não têm sido observados, visto que o número de propostas ainda é inferior ao orçamento disponibilizado.

\footnotetext{
Art. 4ำ Em áreas urbanas, deverão ser respeitados os seguintes critérios de prioridade para projetos do MCMV, observada a regulamentação do Ministério das Cidades:

I - a doação pelos estados, pelo Distrito Federal e pelos municípios de terrenos localizados em área urbana consolidada para implantação de empreendimentos vinculados ao programa;

II - a implementação pelos estados, pelo Distrito Federal e pelos municípios de medidas de desoneração tributária para as construções destinadas à habitação de interesse social; e

III - a implementação pelos municípios dos instrumentos da Lei no 10.257, de 10 de julho de 2001, que visam ao controle da retenção das áreas urbanas em ociosidade ${ }^{104}$.
}

Sem uma política explícita para o tema, a lógica do menor preço de terreno para impactar menos no valor da obra, torna-se a regra. A fórmula é clara: quanto menor o custo do terreno, maior a possibilidade de lucro da construtora, já que o teto do programa é

\footnotetext{
${ }^{102}$ Disponível em:

<http://www.camara.gov.br/proposicoesWeb/prop_mostrarintegra;jsessionid=A50F2C4611E4CEA9AD48BB13 6818CC5A.node2?codteor $=646031$ \& filename $=$ TramitacaoEMC+87/2009+MPV45909+\%3D\%3E+MPV+459/2009>. Acesso em: 7 jan. 2013.

${ }^{103}$ No MCMV-E e PNHR, a responsabilidade é da entidade proponente, e na Oferta Pública de Recursos (Sub 50) cabe ao município.

${ }^{104}$ Decreto 7.499, de 16 de junho de 2011.
} 
prefixado de acordo com a população do município e estado em que está inserido e se pertence a alguma região metropolitana.

Além disso, como o programa atende a diferentes faixas, uma lógica perversa direciona os melhores terrenos às Faixas 2 e 3, segmento econômico que depende de aceitação de "mercado", já que esses empreendimentos são vendidos, pelos próprios empreendedores, diretamente às famílias, que buscam o financiamento do MCMV. Fix (2011, p. 192) comenta o impacto desse segmento no mercado imobiliário:

\begin{abstract}
A atuação no segmento econômico implicou aumento de escala - para obter valor geral de venda elevado com custo unitário mais baixo - e a busca de terras mais baratas. As empresas que atuavam no segmento de luxo estavam habituadas a vender exclusividade, ou seja, viviam em grande medida de oferecer um diferencial em relação ao restante da cidade. [...]

Esse mecanismo não funciona, no entanto, no chamado segmento econômico. Ou melhor, funciona ao revés. As empresas passam a procurar terras que antes não apresentavam interesse, justamente pela precariedade da infraestrutura e pela distância em relação aos centros de dinheiro e poder. Começam mesmo a disputar terras com os movimentos populares e as Cohabs, que antes viam nessas terras as únicas passíveis de serem adquiridas para a implantação de conjuntos habitacionais. Além disso, as empresas beneficiam-se de uma diminuição da desigualdade entre os rendimentos dos trabalhadores (mas não na distribuição funcional da renda entre lucro e salário). Embora pequena e restrita, essa redução contribui para incluir, via consumo, uma parcela da população na clientela das empresas.
\end{abstract}

Os recursos captados no mercado de capitais, como visto, são, em parte gastos na compra de terras. A procura simultânea de tantas empresas capitalizadas gera forte disputa, inicialmente ainda concentrada em poucas cidades. O resultado é a elevação significativa do preço da terra em algumas regiões, dificultando a realização de novos empreendimentos para o segmento.

Para a Faixa 1, as construtoras praticam o limite mínimo aceitável, de acordo com as regras do programa, já que contam com demanda cativa, sempre muito maior do que o volume produzido, e previamente selecionada e organizada pelo poder público. Para essa faixa, sobram os terrenos ainda mais distantes e de custo mais baixo, não raras vezes com o apoio do município na alteração de legislação e/ou implantação de infraestrutura requerida pelo programa. A regulamentação do programa destinado à Faixa 1, em parceria com as construtoras (PNHU com recursos do FAR), coloca alguns requisitos, para a utilização de 
terrenos, que determinam o que e onde o programa pode atuar. Ainda segundo Fix (2011, p. 143):

\begin{abstract}
O modelo favorece, no caso da provisão de 0 a 3 salários, principalmente a produção de casas térreas em grandes conjuntos nas periferias urbanas ou em áreas rurais que serão transformadas em urbanas. A operação depende da mudança nos limites do perímetro urbano autorizada pelas Câmaras Municipais que, frequentemente, representam os interesses dos proprietários de terra. Apenas essa mudança da venda da terra de hectares (área rural) para metros quadrados (área urbana) é mecanismo poderoso de apropriação de renda.
\end{abstract}

Os terrenos a serem utilizados no programa devem estar totalmente regularizados nos aspectos dominial e de parcelamento, no início do processo. Não podem incidir dívidas ou hipotecas sobre os mesmos e, quando da aquisição de terrenos, sobre os proprietários. Os imóveis a serem produzidos devem estar licenciados e em condições de terem sua propriedade transmitida ao beneficiário final tão logo sejam entregues. Essa condição é uma mudança de paradigma, se comparamos com o histórico da produção habitacional em programas habitacionais no Brasil. Muitos, por que não dizer a maioria dos imóveis produzidos pelas diferentes políticas públicas, continham algum grau de irregularidade. Terrenos ainda em processo de desapropriação, sem registro, ou com matrículas imprecisas e conflitantes nos Cartórios de Registro de Imóveis, parcelamentos e edificações não aprovados e/ou averbados nas matrículas foram uma constante dessa produção.

A título de exemplo, imóveis produzidos na década de 1980, pela Cohab-SP, só foram regularizados cerca de 20 anos depois ${ }^{105}$, após um esforço da empresa específico para essa finalidade. Em 2007, a CDHU contabilizava cerca de 80\% das unidades construídas com algum tipo de irregularidade ${ }^{106}$. Os próprios financiamentos, concedidos por meio do programa Operações Coletivas, com recursos do FGTS, também não tinham a regularidade plena como exigência prévia. Ou seja, produzir moradias para famílias de baixa renda de forma regular não estava na cultura da maioria dos órgãos públicos.

O principal argumento para essa exigência, no MCMV, além da perspectiva de dar uma escritura ao beneficiário final, é a garantia do financiamento, especialmente na forma de alienação fiduciária, onde, em caso de inadimplência, o agente financeiro pode retomar o

\footnotetext{
${ }^{105}$ A Cohab Juscelino Kubitscheck, em São Paulo, iniciada em 1984 e entregue em 1987, teve sua regularização concluída em 2003 (COHAB, 2013).

106 UNMP. Audiência com Secretaria Nacional de Habitação. 2007.
} 
imóvel através de processo administrativo e com brevidade. Para o instrumento ser aplicável, deve estar gravado em uma matrícula no Registro de Imóveis, só permitido nos casos em que cada unidade habitacional tenha sua regularidade plena.

Esse parâmetro estendeu-se a todo o programa, inclusive na Faixa 1, em que a fonte de recursos não é onerosa, mas orçamentária, e os níveis de subsidio, como já apontado, chegam a 95\%. Ou seja, uma medida extrema, com molde bancário, foi aplicada a um programa de caráter social. Ao estabelecer um programa com esse formato, o MCMV delimita o mercado formal como seu espaço de atuação, a propriedade privada individual e registrada como único modelo e exclui quaisquer outras formas de acesso à moradia, como locação social ou propriedade coletiva ou cooperativa.

Além da regularidade, o programa formalmente coloca requisitos de localização para a utilização de terrenos. Esse tema sofre diversas alterações, ao longo dos quatro anos de existência do MCMV. A primeira regulamentação, ocorrida ainda em 2009 ${ }^{107}$, era bastante vaga, se comparada à vigente no $\mathrm{MCMV} 2^{108}$, que coloca mais condicionantes para a habilitação de áreas.

Em ambas, exige-se que o terreno seja localizado "em área urbana ou de expansão urbana, conforme previsto no plano diretor do município". Exige-se também que os terrenos "contem com a existência de infraestrutura básica que permita as ligações domiciliares de abastecimento de água, esgotamento sanitário e energia elétrica, bem como vias de acesso e transportes públicos" ${ }^{109}$. Essas medidas visavam impedir a construção de conjuntos em áreas isoladas e sem acesso. No entanto, verificação empírica do que já foi produzido e entregue no MCMV demonstra que esses regramentos não foram suficientes para coibir conjuntos em áreas distantes e descoladas da malha urbana. Foram verificadas também, mudanças em legislações municipais, a fim de "ajustar" terrenos indicados às exigências normativas, como a extensão de perímetro urbano ou de expansão urbana.

\footnotetext{
107 Portaria 139, de 13 de abril de 2009, do Ministério das Cidades.

108 Portaria 465, de 3 de outubro de 2011, do Ministério das Cidades e suas alterações.

${ }^{109}$ Anexo II da Portaria 139, de 13 de abril de 2009, do Ministério das Cidades.
} 
Figuras 30, 31 e 32 - Exemplos de Conjuntos do MCMV - FAR distantes do tecido urbano - 2010 e 2011
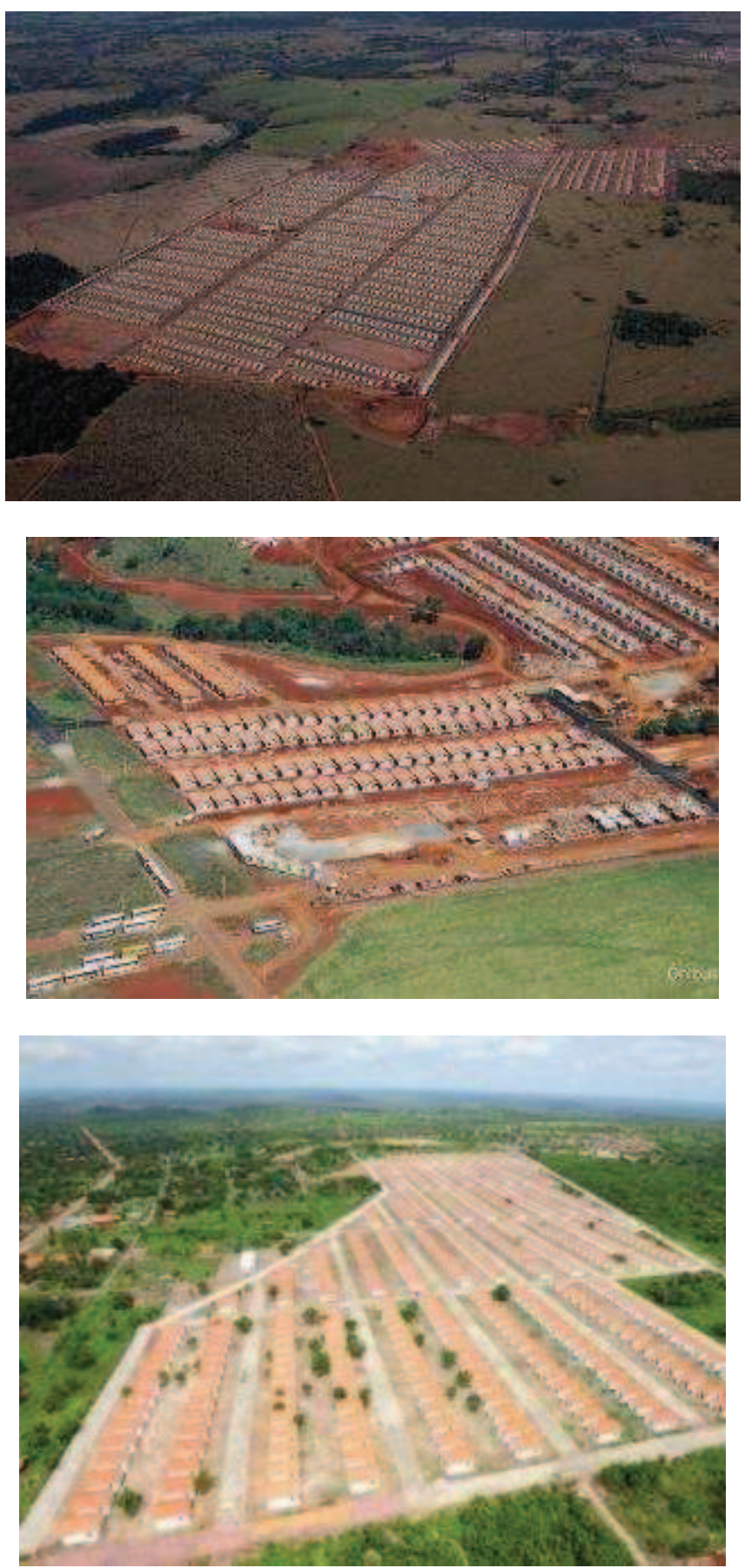

Fonte: MCidades

O tamanho dos empreendimentos foi outro ponto de controvérsia. Na primeira versão, os empreendimentos poderiam ter no máximo 500 unidades. Não havia, no entanto, impedimento, para a construção de diversos módulos contíguos, gerando, na prática, grandes conjuntos. O maior deles, Meu Orgulho (hoje, Viver Melhor), em Manaus, somadas a primeira e a segunda fases, somará 8.895 unidades. 
Figura 33 - Residencial Meu Orgulho - Manaus/AM (foto parcial) - 2012

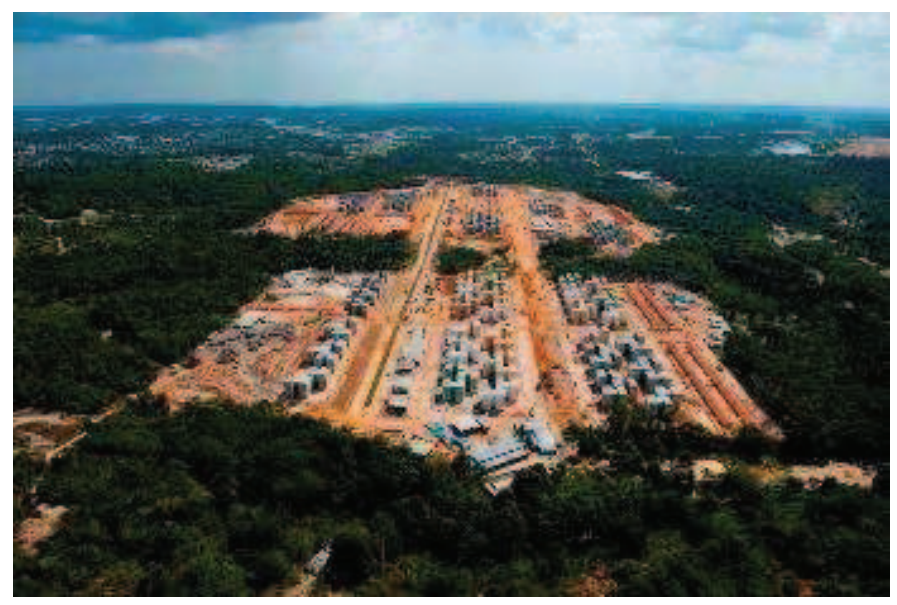

Fonte: Valor Econômico

No MCMV 2, a questão é regulamentada de forma mais precisa, tendo sido introduzidos condicionantes diferenciados, como a garantia de existência de área para a implantação dos equipamentos sociais para os empreendimentos acima de 1.000 unidades e limitando o conjunto de empreendimentos contíguos em uma mesma área em 5 mil unidades.

No MCMV 1, previa-se que deveria "ser considerada a existência ou ampliação dos equipamentos e serviços relacionados à educação, saúde e lazer"110, sem mais especificações sobre o tema, sendo que os municípios assinavam um termo de adesão ao programa, com o compromisso de atender à demanda gerada pelos novos conjuntos. $\mathrm{Na}$ segunda etapa, essa exigência se aprofunda, com a necessidade de uma série de procedimentos que envolvem diretamente o MCidades e o município, para o atendimento dessas demandas sociais, com a destinação de área para os equipamentos sociais e a assinatura de uma Matriz de Responsabilidade por parte dos municípios, com dotações orçamentárias e compromisso na execução dos equipamentos, atendimento das demandas de saúde, educação e transporte. Cabe aos municípios disponibilizar os recursos para esses equipamentos ou captá-los nos órgãos relacionados, executar as obras e colocá-los em funcionamento em tempo compatível com a entrega dos conjuntos.

\footnotetext{
110 In: Anexo único, item 4.1.1 da Portaria 139, de 13 de abril de 2009, do Ministério das Cidades
} 
Figura 34 - Exemplo de empreendimento do MCMV - FAR inserido na malha urbana - 2011

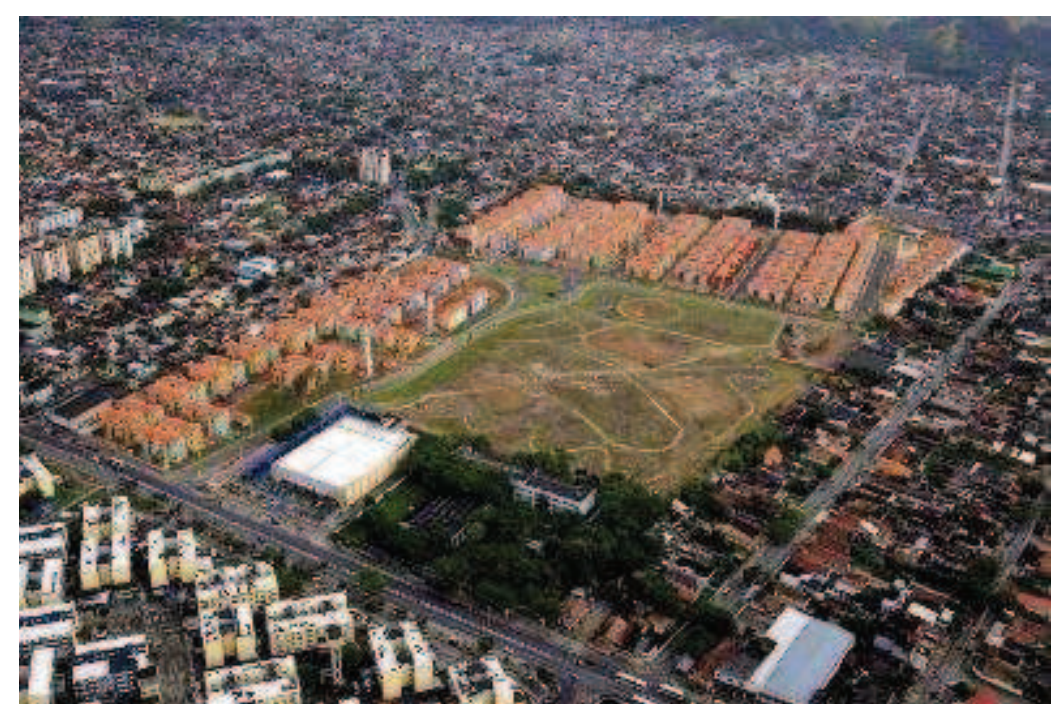

Fonte: MCidades

Essas exigências foram contestadas por diversos atores ligados ao setor da construção e ao poder público local. A necessidade de pavimentação nos conjuntos e viabilização dos equipamentos foi alvo de ataques, como o realizado pelo secretário de estado de Habitação e das Cidades do Mato Grosso do Sul e presidente do Fórum Nacional de Secretários de Habitação e Desenvolvimento Urbano, Carlos Marun:

Seria ótimo podermos entregar residenciais com toda a infraestrutura. Mas vejo como prioridade a remoção e realocação de famílias que morem em área de risco e/ou favelas. Entregamos casas em condições de habitabilidade, ou seja, possuem rede de energia, água, esgoto e arruamento. As demais benfeitorias vêm com o tempo. Asfalto, creche, escola, posto de saúde, isso é conquistado pela comunidade ${ }^{111}$.

Como já explicitado, os terrenos podem ser adquiridos com recursos do programa, doados ou cedidos por órgãos públicos, assim como a execução da infraestrutura. $\mathrm{Na}$ primeira versão do MCMV, caso houvesse algum aporte de órgãos públicos, em dinheiro, bens ou serviços, esse valor seria descontado do teto para o programa. Atualmente, esse dispositivo foi alterado e os recursos podem ser incorporados às propostas, desde que sejam destinados à viabilização do empreendimento, ao aumento da área da unidade e número de cômodos ou equipamentos comunitários. No caso da rede elétrica, resolução da Aneel ${ }^{112}$

\footnotetext{
${ }^{111}$ Entrevista ao Jornal Dourados Agora. Disponível em: <http://www.douradosagora.com.br/noticias/capital/secretario-defende-nao-exigencia-de-pavimentacao-nominha-casa-minha-vida-ii>. Acesso em: 12 nov. 2012.

112 Resolução Normativa 414, de 9 de setembro de 2010, da Agência Nacional de Energia Elétrica (Aneel).
} 
determina que as concessionárias devem instalar, sem ônus para a construtora, a rede em empreendimentos do MCMV. Ou seja, todos os aportes complementares, inclusive de terreno, não servem para baratear o custo de produção das unidades.

Os agentes promotores do MCMV têm privilegiado a adoção do condomínio como forma de parcelamento dos empreendimentos. Alegando as exigências da Lei 6.766/1979, como a doação de áreas públicas e o tempo necessário para a aprovação de loteamentos, grande parte dos conjuntos tem sido edificada em forma de condomínios, ou figuras jurídicas semelhantes, criadas por legislação municipal, independentemente da tipologia das habitações (casas ou apartamentos). É necessário ressaltar que a figura do condomínio de um conjunto de casas é uma figura controversa, adotada em legislação municipal, mas que não existe na Lei 6.766 e revisões, questionada em diversas ações judiciais promovidas pelo Ministério Público em variadas partes do País.

Na Faixa 1, destinada a famílias de baixa renda, poder-se-ia questionar a sustentabilidade dessa opção, já que teriam grandes extensões de área privativa do condomínio e, portanto, não públicas, para custear a manutenção, onerando ainda mais seu orçamento doméstico. Considerando esse problema, que já aparece em conjuntos da primeira etapa, que já foram entregues, o normativo do programa inclui no Termo de Adesão a ser assinado por estados e municípios o compromisso de promover "ações para viabilizar a manutenção das vias, calçadas e áreas verdes comuns internas dos empreendimentos operados com recursos do Fundo de Arrendamento Residencial (FAR), organizados sob a forma de condomínio"113. Tal dispositivo pode ser questionado tanto por ferir a autonomia municipal quanto por imputar ao poder público a manutenção de uma área, em última análise, privada.

O MCMV tem sido apontado como indutor de um boom no aumento preço dos terrenos para habitação. Por isso, houve pressão do setor da construção civil e o programa, na Faixa 1, já registra três reajustes no valor do teto de financiamento, desde o seu lançamento, em 2009. Essa fórmula tem característica autofágica, já que a cada aumento do teto do programa, na ausência de qualquer política fundiária, novamente aumenta o preço

\footnotetext{
113 Item "q" da cláusula 2a do Modelo de Termo de Adesão contido na Portaria 465, de 3 de outubro de 2011, do Ministério das Cidades, e suas alterações.
} 
dos terrenos. Ao mesmo tempo em que têm apontado o aumento dos preços de terrenos como dificuldade na operação do programa, empresários do setor defendem explicitamente a elevação do teto nas diversas faixas de renda: "O que é necessário para que o programa deslanche é uma constante atualização dos valores que poderão ser financiados. É o custo do terreno e da mão de obra, é a lei da oferta e da procura. Então é preciso que o valor do programa vá ao encontro daquilo que vemos no mercado"114.

Bonduki (2009, p. 7), por ocasião do lançamento do programa, já alertava:

\begin{abstract}
A localização dos empreendimentos poderá ser inadequada, em áreas carentes de emprego, infraestrutura e equipamentos, correndo o risco, ainda, de gerar impactos negativos como a elevação do preço da terra, que representaria a transferência do subsídio para a especulação imobiliária, desvirtuando os propósitos do programa.
\end{abstract}

Esse modelo com que as políticas habitacionais têm tratado a questão da terra, de forma desarticulada, na maioria das vezes, com o planejamento urbano, afeta também o mercado imobiliário. O discurso da falta de terrenos disponíveis para habitação popular

\begin{abstract}
tem um duplo efeito: legitima a demanda por um aumento no valor do financiamento para os mais pobres e oculta as práticas especulativas das próprias construtoras, geradoras da valorização fundiária que se dá através da combinação da estocagem de terras na periferia com a produção em grande escala de empreendimentos para os segmentos acima de três salários. (LAGO, 2011, p.7).
\end{abstract}

A Câmara Brasileira da Indústria da Construção Civil (CBIC) qualifica como uma ameaça ao programa a escassez de terrenos a preços compatíveis. A direção da entidade afirma que a especulação imobiliária é um "fenômeno natural", impossível de ser contido. Em recente documento da entidade, além de propor medidas imediatas, como redução da burocracia, financiamento para aquisição de terrenos e não incidência dos custos de infraestrutura sobre os imóveis, afirma que

A carência de terrenos urbanizados dentro dos centros urbanos aponta para a necessidade de construção de 'minicidades' localizadas na periferia dos grandes centros. Essas novas áreas habitacionais - diferentemente do que aconteceu no passado - precisam ser cuidadosamente planejadas para atender às distintas

\footnotetext{
114 Preços limitam alcance do Minha Casa. Disponível em: <http://www.gazetadopovo.com.br/imobiliario/conteudo.phtml?id=1329110\&tit=Precos-limitam-alcance-doMinha-Casa>. Acesso em: 6 jan. 2013.
} 
demandas da população: saúde, educação, lazer, emprego e locomoção, dentre outras $^{115}$.

A proposta articula-se com a modelagem das Parcerias Público-Privadas (PPPs) e tem sido defendida em atividades públicas, pelo setor. Com nova roupagem, a solução apontada é negar a cidade e seus conflitos, expulsar a população mais pobre e, dessa dificuldade, fazer novos e lucrativos negócios.

O programa também não apresenta distinção de estratégias ou valores, para a localização intraurbana dos empreendimentos, ou seja, o mesmo teto de valor é destinado para uma moradia localizada em áreas mais centrais ou nas franjas periféricas de determinada cidade ou Região Metropolitana. Essa posição praticamente arbitra a localização dos imóveis da Faixa 1 e não atribui a melhor localização como item de qualidade ou priorização no programa, como propõe o PlanHab, nem estimula a utilização dos diversos instrumentos previstos no Estatuto da Cidade, com a finalidade de prover terra urbanizada e mais barata para habitação popular. Bonduki (2009, p. 13) destaca que

\begin{abstract}
O programa não adota o conjunto das estratégias que o PlanHab julgou indispensável para equacionar o problema habitacional, sobretudo nos eixos que não se relacionavam com os aspectos financeiros; em consequência, aborda-o de maneira incompleta, incorrendo em grandes riscos, ainda mais porque precisa gerar obras rapidamente sem que se tenha preparado para isso.
\end{abstract}

Apesar de prever, em suas modalidades, a requalificação de imóveis vazios, convertendo-os em HIS, o programa, até dezembro de 2012, não contrata nenhuma operação desse caráter. Alguns critérios do programa são flexibilizados para essa finalidade, como valores e área mínima das unidades. Em 2013, está prevista a contratação de alguns empreendimentos em imóveis cedidos pela Secretaria do Patrimônio da União e adquiridos do Fundo Previdenciário, que não terão incidência no valor da requalificação. Essas exceções apenas confirmam a regra da não adequação do MCMV para outra tipologia que não seja o típico conjunto habitacional.

Um mês após o lançamento do MCMV, a União dos Movimentos de Moradia de São Paulo realiza ato público e diversas ocupações, denominados Minha Casa e Minha Vida são

\footnotetext{
${ }^{115}$ CBIC. Terra urbanizada. Position Paper. Disponível em: <http://www.cbic.org.br/sala-de-imprensa/positionpapers/terra-urbanizada>. Acesso em 2 jan. 2012.
} 
no Centro!, reivindicando a utilização de imóveis ociosos, públicos e privados, para o programa. Em seu manifesto, afirmam:

Lutamos pelo direito de morar em áreas urbanizadas, infraestruturadas e com acesso a equipamentos sociais, transporte e, principalmente, próximo ao local de trabalho! Queremos nossas casas próximas aos locais onde construímos nossas vidas! (UMM-SP, 2009). 
5 A QUESTÃO DA TERRA NOS PROGRAMAS AUTOGESTIONÁRIOS DE MORADIA POPULAR 


\subsection{Movimentos Sem-Terra na cidade}

A questão do acesso à terra para moradia foi a primeira luta travada pelos movimentos por moradia, especialmente naqueles que adotam a proposta autogestionária, e sempre esteve em sua pauta prioritária. Característica de diversos movimentos de moradia formados na década de 1980 é a autodenominação Movimentos Sem-Terra ${ }^{30}$. Esse fenômeno urbano ocorre simultaneamente com a formação do Movimento dos Trabalhadores Rurais Sem-Terra (MST), no momento da redemocratização do País. A expressão "sem-teto", utilizada hoje por vários movimentos e pelos meios de comunicação, apareceu bem depois, na década de 1990.

Ao serem questionados sobre a razão de serem denominados de "sem-terra" e não "sem-teto", diversos documentos e lideranças indicam tanto a origem dos movimentos nas ocupações de terra, quanto a prioridade dada ao tema na formação e organização das agendas de luta, bem como o caráter político dessas ações, ao denunciarem a exclusão social e a territorial. Em um de seus manifestos, ainda na década de 1980, o Movimento Sem-Terra da Zona Leste afirmava:

A terra foi destinada a todos. No Brasil, grupos de poderosos dentro do governo e com apoios armados roubaram a terra [...] Cidade e campo estão unidos nesta luta por terra e moradia. A terra e moradia não são somente abrigo para a sobrevivência, é o lugar de ser cidadão, de fazer a nossa história ${ }^{116}$.

Para além da semântica, também foi consagrado pelos movimentos o termo "ocupação", em oposição ao termo "invasão", este até hoje utilizado pelos governos e meios de comunicação como forma de criminalizar as ações de luta dos movimentos, provocando discriminação na sociedade. Ocupação, nesse contexto, é a expressão legítima da luta organizada para garantir o acesso à terra e moradia.

A maioria desses movimentos urbanos e seus contemporâneos iniciou-se nas grandes ocupações de terra ocorridas em periferias de diversas cidades, no final da década de 1980 . Dados da UMM (1993) mencionam mais de 100 mil pessoas em ocupações coletivas de terra em São Paulo, em 1987. Rodrigues e Conforto elencam "a falta de áreas para novas favelas,

\footnotetext{
${ }^{116}$ Folheto do Movimento Sem Terra da Zona Leste, São Paulo, 1987.
} 
o inchaço das já existentes, as restrições impostas pelas novas leis dificultando a abertura de novos loteamentos (Lei 6.766/79), valorização da terra urbana, aliados à crise econômica, inflação e desemprego"(1992, p. 89) como principais fatores conjunturais para esse fenômeno. Esse processo sofreu mudanças ao longo da década de 1980.

Em 31/3/1987 o pedreiro Adão Manoel foi morto a tiros pela guarda metropolitana. Seu enterro foi um protesto político de mais de 4.000 pessoas gritando o slogan "o povo sem-terra é capaz de ir à guerra". Não foram à guerra, mas perceberam claramente que a luta pelo acesso à terra é questão de vida ou morte. (RODRIGUES e CONFORTO, 1992, p. 89).

As primeiras ocupações massivas tinham caráter de solução imediata, com o "loteamento", pela própria organização, da área ocupada e cada família teria que construir em seu lote. Num segundo momento, as ocupações passaram a ser coletivas, sem a demarcação de lotes individuais e com a reivindicação de que o poder público viabilizasse a aquisição do terreno e posterior financiamento para a construção das moradias.

Figura 35 - Ocupação Jd. S. Francisco - 1993 - São Paulo-SP

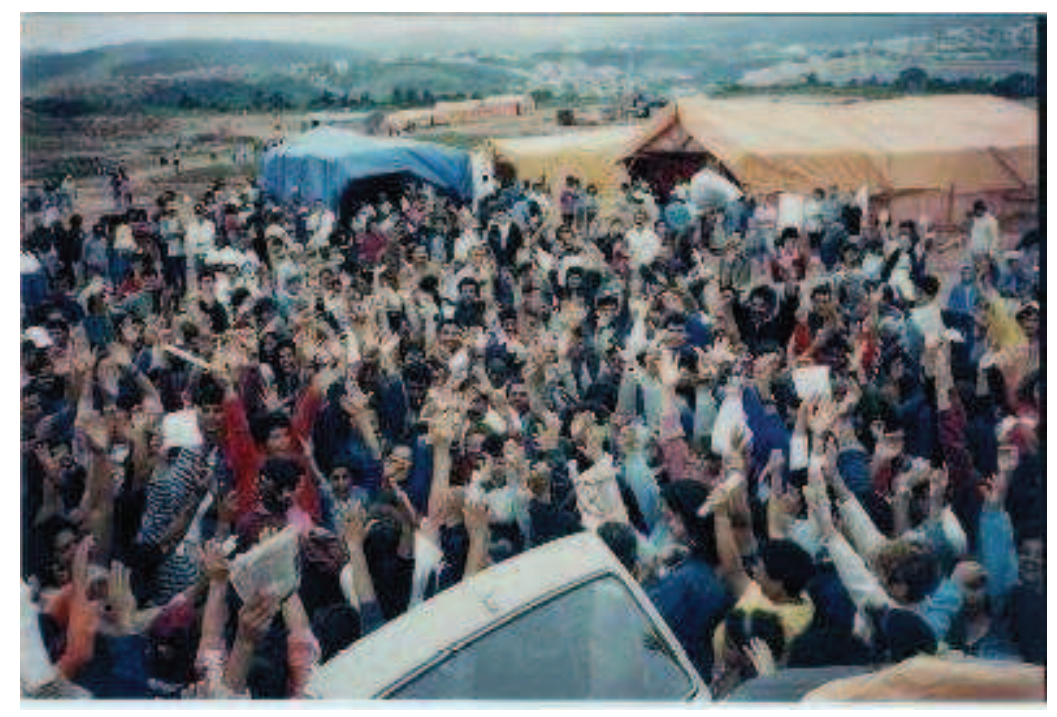

Fonte: Acervo UMM-SP

Esse processo forneceu a base social necessária para a organização de diversos movimentos de moradia, os quais, a partir da ocupação e articulação de diversos grupos, deram os primeiros passos para a elaboração de propostas para as políticas habitacionais e também para o caráter emancipatório dessas organizações. Fundadores da UMM-SP comentam: 
Um grupo de lideranças começou uma articulação, chamada União dos Movimentos de Moradia, a partir das ocupações de terra que ocorreram. Através dessas ocupações, começou-se a discutir uma proposta habitacional. (...) Através da luta concreta, (as pessoas) começam a entender o que é a cidade capitalista, como é organizada, como acontecem as relações de exploração em nível econômico, social e político (RODRIGUES e CONFORTO, 1992, p. 89).

Paz (1996, p. 90) ressalta a importância desse processo de ocupações para a organização e a formação do ideário desses movimentos:

\begin{abstract}
Os movimentos de ocupação tiveram um grau de vitória pequeno, sendo a maioria desalojada ou transferida, mas representaram, nos anos 80 , a denúncia de falta de políticas públicas para o setor e as dificuldades de acesso à terra, como também a abertura de negociações com os governos estaduais e municipais.(...) Debates, palestras sobre a função social da terra, a especulação imobiliária, a propriedade privada, o BNH, o FGTS, etc., passaram a fazer parte do universo de compreensão de trabalhadores, que inicialmente apenas queriam conquistar sua casa.
\end{abstract}

As ocupações em São Paulo acabam por pressionar o governo estadual a adquirir diversas glebas periféricas para a construção de conjuntos habitacionais. O movimento monitora a aquisição dessas áreas que foram, em alguns casos, compradas de seus proprietários e, em outros, desapropriadas. Várias denúncias ocorrem, acusando os processos de superfaturamento nos valores dos terrenos. Algumas áreas foram destinadas a programas de habitação com autogestão, mas a maioria, especialmente as adquiridas pelo governo do Estado, acabou sendo destinada para programas convencionais com empreitada global e sem nenhuma participação dos movimentos que se envolveram na luta por obtê-las.

A pauta da moradia em áreas centrais coexiste com todo esse processo. Concomitantemente com as lutas para a melhoria das condições de vida nos cortiços (contratos de locação e sublocação, tarifas sociais de água e luz, manutenção), desde o final da década de 1980, movimentos de cortiços de São Paulo formulam propostas para a questão da moradia no centro:

1) Moradia para os trabalhadores no centro da cidade, pois os mesmos têm esse direito; 2) desapropriações de cortiços, para futuros repasses aos movimentos e às famílias; 3) financiamento para construção de nova edificação adaptando a moradia a padrões adequados e dignos; 4) um estudo para a reformulação do zoneamento de áreas de cortiços (OLIVEIRA, 1992, p. 81). 
Nesse momento, são registradas algumas vitórias pontuais, com os primeiros projetos habitacionais em área central, como os mutirões Madre de Deus e Celso Garcia ${ }^{117}$. O tema volta a ter incidência a partir de 1997, com ocupações organizadas pelos movimentos de moradia em imóveis ociosos do centro. Devido à sua visibilidade e por expor o tema da ociosidade de imóveis em áreas dotadas de toda a infraestrutura, as ocupações em prédios em áreas centrais obtêm grande atenção da mídia. E, embora, até hoje não se configurou em uma política habitacional efetiva, apenas com alguns projetos pontuais, esses conflitos colocaram o tema na agenda dos governos.

Figura 36 - Ocupação imóvel público em área central - São Paulo-SP - 1997

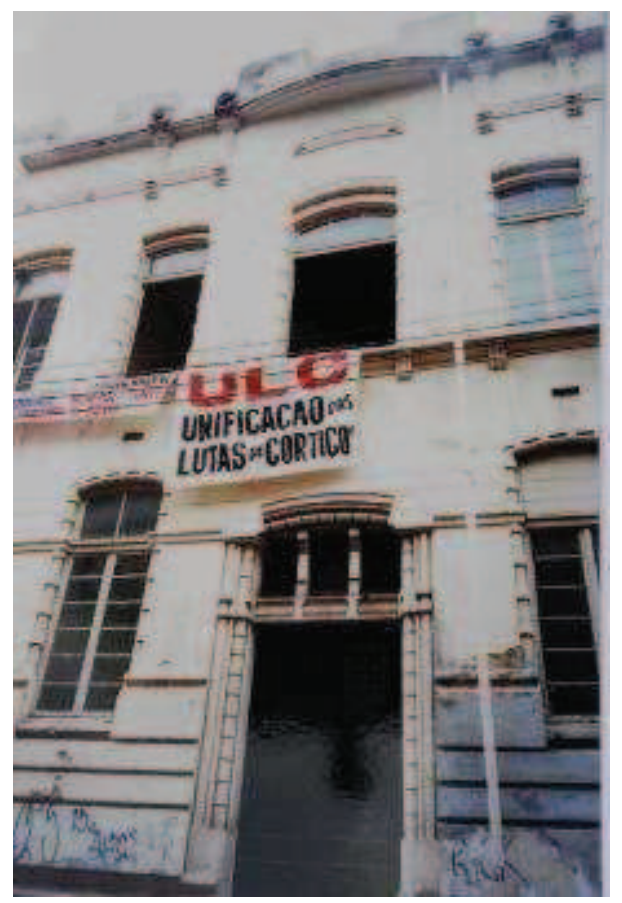

Fonte: Acervo UMM-SP

117 São dois cortiços adquiridos pela Prefeitura de São Paulo, na gestão 1989-92, bem como alguns terrenos vizinhos, onde foram construídos dois empreendimentos habitacionais autogestionários, pioneiros na proposta de moradia popular em área central. 
Figura 37 - Manifestação em defesa de moradia em área central - São Paulo-SP - 2006

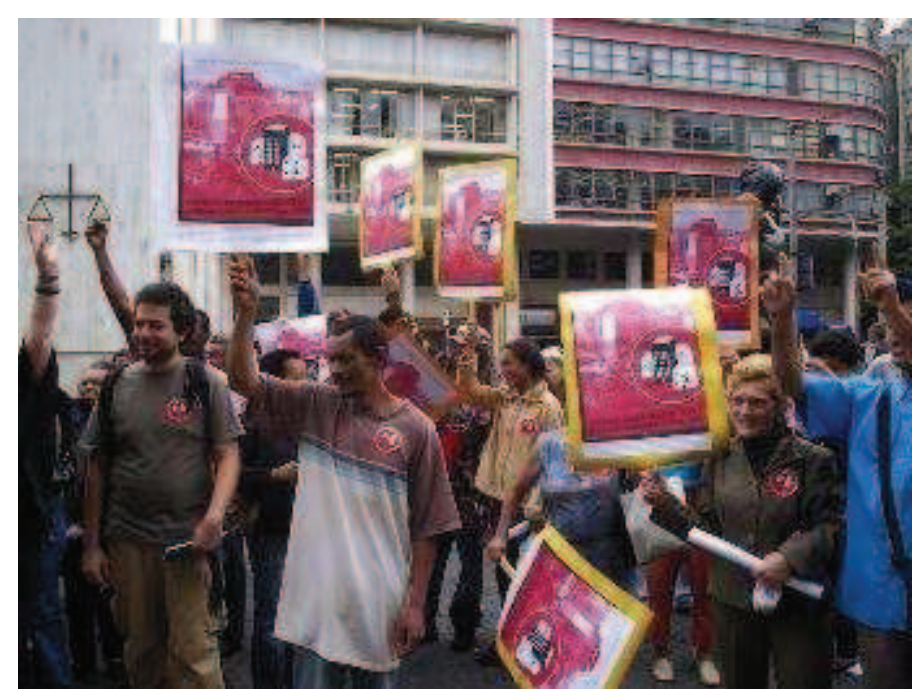

Fonte: Acervo UMM-SP

Nesses e em diversos momentos dessa trajetória, as ocupações geraram um grande número de processos judiciais contra as lideranças dos movimentos, "por formação de quadrilha, como uma forma de deter a força que vínhamos acumulando através de articulações com movimentos" explica Tijiwa (1993, p. 32). O processo de criminalização de lideranças por ocupações de terras e prédios ociosos torna-se constante, deixando claro que a exigência do cumprimento da função social da propriedade defronta-se com limites claros quando questiona o direito de propriedade, como afirma Maricato (2011, p. 190):

A construção ideológica que cerca o conceito de propriedade privada é tão forte que, numa inversão completa de papéis, homens e mulheres que deveriam se beneficiar da aplicação das leis, e em nome dos quais elas são aprovadas, são acusados de se insurgir contra elas.

A questão da terra permanece na agenda dos movimentos e a estratégia da ocupação de terras e edifícios ociosos, públicos e privados, nunca foi abandonada e continua, até os dias de hoje, sendo adotada pela maioria dos movimentos por moradia. A partir de 2004, já com a organização do movimento em nível nacional, a UNMP passa a adotar como estratégia realizar ocupações simultâneas em diversos estados, com uma bandeira de luta unificada em nível nacional combinada com pautas locais.

A estratégia inspira-se nas mobilizações do MST, como o Abril Vermelho, e em ações coordenadas do movimento de moradia que vinha ocorrendo em São Paulo e Recife. A 
proposta dá visibilidade à articulação do movimento e às pautas da política nacional de habitação, com enfoque em imóveis públicos. Em alguns momentos, o FNRU ao articular os quatro grandes movimentos nacionais, também adota a mesma estratégia, combinado as ações locais com mobilizações e caravanas a Brasília.

\subsection{A questão da terra nos programas locais de autogestão}

A destinação de áreas públicas, ou adquiridas pelo poder público, para programas de habitação autogestionários foi utilizada na maioria das experiências anteriores aos programas Crédito Solidário e Minha Casa Minha Vida. Os movimentos reivindicavam a desapropriação de uma área ou, no caso de áreas já pertencentes ao poder público, a sua destinação para os programas habitacionais.

No caso do programa de Mutirões da Cidade de São Paulo (1989-1992), contou-se com áreas municipais ou em processo de desapropriação, áreas de propriedade da Cohab-SP e, em alguns poucos casos, áreas adquiridas pelas associações. Dos 94 contratos firmados, com cerca de 12 mil unidades, pelo menos 68 envolviam terras da prefeitura ou da Cohab, que já eram de sua propriedade ou foram adquiridas na vigência do programa para essa finalidade (FASE, 1995).

No programa estadual, a CDHU detinha um estoque de terras - várias que haviam sido ocupadas pelos movimentos e desapropriadas pelo Estado ${ }^{118}$ - que foi sendo destinado para seu programa de empreitada global e para o Programa Paulista de Mutirões. Nos municípios do interior e em alguns da Região Metropolitana de São Paulo, os terrenos eram viabilizados pelas prefeituras. Em Belo Horizonte/MG, áreas foram adquiridas pela prefeitura e destinadas às associações através de processos de participação, como o Orçamento Participativo da Habitação.

O movimento dos sem-casa, como se verá adiante, conquistou terrenos para construção de moradias nos processos de discussão pública do Orçamento Participativo que aconteceram nos anos de 1993 e 1994. Essas conquistas seriam

118 Inclui-se nessa relação áreas da Fazenda da Juta, de Colorado, Jova Rural, Brasilândia, Vila Sílvia, Voith, entre outras localizadas na periferia da cidade de São Paulo. 
somadas às do Fórum dos Sem Casa e agregadas, mais tarde, às conquistas obtidas no Orçamento Participativo da Habitação (OPH), criado em 1995. (...) A Urbel encaminhou, então, a definição e a desapropriação dos terrenos e, dentre eles, quatro foram destinados a empreendimentos por autogestão, por decisão da Comforça Habitação ${ }^{119}$ e dos núcleos contemplados. (BEDÊ, 2005, p. 242).

Após a conquista de determinada área e sua destinação para determinado grupo ou associação iniciavam-se os procedimentos para viabilizar o financiamento da construção. Ou seja, a definição do terreno iniciava o processo de autogestão. A associação passa, a partir daí, a definir o grupo de participantes, a assessoria técnica, a elaboração de projetos e orçamentos e a buscar as aprovações. Todos esses passos só eram dados após a "garantia" de que determinado terreno estava destinado para aquele grupo. Geralmente, a área já estava atrelada a determinado número de unidades habitacionais e a um valor teto de financiamento que limitaria a proposta a ser apresentada. Em alguns casos, o poder público responsabilizava-se pela infraestrutura, mas observam-se casos em que às associações também cabia a execução de terraplenagem, ligações de água, energia e esgoto.

Uma exceção a esse modelo ocorreu na cidade de Goiânia/GO onde as associações já haviam adquirido terrenos em gleba bruta e buscavam recursos municipais e estaduais para a construção dos conjuntos habitacionais.

No estado de São Paulo, quando os estoques de terra da CDHU começaram a se esgotar, os movimentos sociais, por iniciativa do então deputado estadual Roberto Gouveia (PT) conquistaram a Lei da Compra da Terra ${ }^{120}$, que destina recursos do governo do estado para associações, cooperativas e sindicatos adquirirem terrenos, visando à construção de casas populares por mutirão ou autogestão. O projeto de lei, apresentado em 1997, levou três anos para ser aprovado e nunca foi implementado, coincidindo com o declínio do programa de mutirões do governo estadual. De qualquer forma, a proposta refletiu a dificuldade de viabilizar áreas para habitação e também questionava a forma de aquisição feita por desapropriação, com várias denúncias de superfaturamento do preço dos terrenos.

\footnotetext{
${ }^{119}$ A Comforça Habitação é uma instância de participação, eleita no Fórum Municipal da Habitação, composta por movimentos de moradia que fiscalizam a aplicação dos recursos e acompanham a execução das obras do Orçamento Participativo da Habitação, no Município de Belo Horizonte.

120 Lei Estadual 10.535, de 4 de abril de 2000.
} 


\subsection{Terra nos programas federais - PCS e MCMV}

Desde o lançamento do PCS, os movimentos alertaram para a dificuldade de inserção das famílias de mais baixa renda e da viabilização de áreas bem localizadas para o programa. Como relatado no capítulo anterior, essa situação foi agravada com o boom imobiliário que antecedeu à crise financeira mundial, de 2008. Os movimentos sentiram cada vez mais dificuldades em negociar terrenos para o programa e desencadearam um processo de ocupações, prioritariamente em áreas do governo federal, como as ocorridas em abril de 2008.

Figura 38 - Ocupação em Superintendência do INSS - São Paulo/SP - 2008

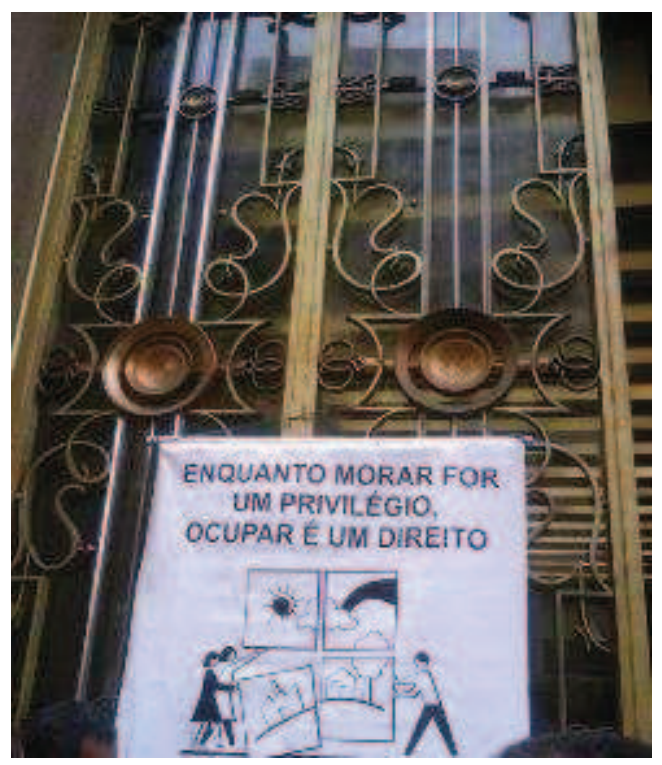

Fonte: A autora.

Estamos em luta porque somos os excluídos e as excluídas da cidade formal. A falta de uma política fundiária, que viabilize o acesso à terra urbanizada às famílias de baixa renda, faz com que, enquanto o mercado imobiliário festeja seus ganhos cada vez maiores e aumentam os financiamentos para as classes alta e média, as poucas terras com infraestrutura urbana disponíveis ficam cada vez mais caras, obrigandonos a morar cada vez mais longe e em condições cada vez piores (UNMP, 2008).

Após o lançamento do MCMV, com a disponibilização de recursos consideráveis para a produção de novos empreendimentos habitacionais, em diversas faixas de renda, os movimentos passam a disputar as mesmas áreas, em condições ainda mais desfavoráveis, com o mercado e o programa do MCMV para a Faixa 1 operado por construtoras. 
O tema fundiário vai ganhando cada vez mais importância na agenda política entre os movimentos e o governo federal. Em reunião com a presidenta Dilma Roussef, ocorrida em 14 de junho de 2012, as lideranças dos quatro movimentos nacionais e do FNRU afirmaram que o principal problema para a implementação do MCMV, especialmente na faixa destinada à mais baixa renda, era a especulação imobiliária e que o governo federal deveria atuar de forma mais incidente sobre o tema.

Conforme exposto no capítulo anterior, os programas federais de habitação sempre se concentraram nos aspectos financeiros e institucionais e delegavam ao agente promotor a viabilização das áreas para os empreendimentos. A mesma lógica foi aplicada aos programas em parceria com os movimentos sociais, como o Crédito Solidário e o MCMV-E.

Os dois programas admitem a construção em terreno próprio, da família ou da entidade, em terrenos doados pelo poder público e em terrenos adquiridos dentro do próprio programa. No MCMV-E, no caso do terreno ter sido doado, o valor teto do empreendimento sofria uma redução de $8 \%$, que poderia ser reincorporada, se a entidade apresentasse unidade maior ou equipamentos comunitários. Essa redução foi extinta no MCMV-E somente em 2012, com a Resolução 193, do CCFDS.

Outra característica dos dois programas é que a contratação da operação só ocorre depois de elaborado, aprovado e licenciado o projeto do empreendimento. Até então, toda a proposta é elaborada sem o aporte de recursos públicos e, caso não se viabilize, o custo financeiro total é arcado pela própria entidade, com recursos de cooperação ou das contribuições das próprias famílias sem-teto. Ou seja, em termos bancários, o "risco" da operação corre totalmente por conta da parte mais fragilizada do processo.

Para verificar as dificuldades e os constrangimentos enfrentados pelas entidades para conseguir viabilizar terrenos para o programa, foram realizadas, no âmbito desta pesquisa, entrevistas com lideranças e assessorias técnicas responsáveis por 40 empreendimentos do PCS e do MCMV-E, contratados ou em via de contratação ${ }^{121}$. Também foram utilizados os dados oficiais quantitativos disponibilizados pelo MCidades e Caixa sobre os programas. Esses dados e entrevistas ilustram as dificuldades encontradas pelas entidades, e como as

\footnotetext{
${ }^{121}$ O Anexo 1 traz a relação dos empreendimentos pesquisados.
} 
regras e normas do programa limitaram sua ação. Mesmo nos casos em que o empreendimento foi viabilizado, ficam evidentes as inúmeras barreiras quebradas.

\subsubsection{Diagnóstico e considerações sobre os empreendimentos pesquisados}

Para esta pesquisa, foram realizadas entrevistas ${ }^{122}$ com lideranças e/ou assessorias técnicas de 40 empreendimentos dos programas Crédito Solidário e MCMV-E, distribuídos pelas cinco regiões brasileiras, contratados entre 2006 e 2012, ou em fase de contratação. Foram levantados dados de 16 empreendimentos do PCS, 23 do MCMV-E e, excepcionalmente, um do programa de Produção Social da Moradia ${ }^{123}$. A amostra representa $8 \%$ do universo total de 480 empreendimentos do PCS e MCMV-E, com 6.778 Unidades Habitacionais (UHs), correspondente a $17 \%$ das unidades contratadas nos dois programas $^{124}$.

Apesar de os empreendimentos estarem distribuídos em 17 municípios, de nove estados, nas cinco regiões, a maioria concentra-se no Sudeste (48\%) e no Nordeste (27\%); 70\% estão localizados em Regiões Metropolitanas, onde se concentram os movimentos de moradia organizados, enquanto que, destes, $45 \%$ se localizam nas capitais e $25 \%$ em outros municípios das Regiões Metropolitanas. (Tabela 7 e Gráfico 5).

\footnotetext{
$122 \mathrm{O}$ roteiro das entrevistas encontra-se no Anexo 2

123 O empreendimento do PSM estudado tem 98 unidades e não está computado nesta amostra. Decidiu-se mantê-lo no estudo por trazer elementos interessantes quanto à estratégia de viabilização.

124 Observados em separado, o PCS teve $5 \%$ de seus empreendimentos pesquisados (com $8,8 \%$ das unidades) e, o MCMV-E, $15,6 \%$ dos empreendimentos, o que representa $26,5 \%$ das unidades.
} 
Tabela 7 - Distribuição regional dos empreendimentos e das unidades habitacionais

\begin{tabular}{l|r|r}
\hline Região & Empreendimentos & \multicolumn{2}{|l}{$\begin{array}{l}\text { Quantidade de } \\
\text { UHs }\end{array}$} \\
\hline Centro-Oeste & 4 & 600 \\
\hline Nordeste & 11 & 1.966 \\
\hline Norte & 3 & 600 \\
\hline Sudeste & 19 & 2.820 \\
\hline Sul & 3 & 890 \\
\hline Total & $\mathbf{4 0}$ & $\mathbf{6 . 8 7 6}$ \\
\hline
\end{tabular}

Fonte: Elaboração própria.

Gráfico 5 - Localização dos empreendimentos

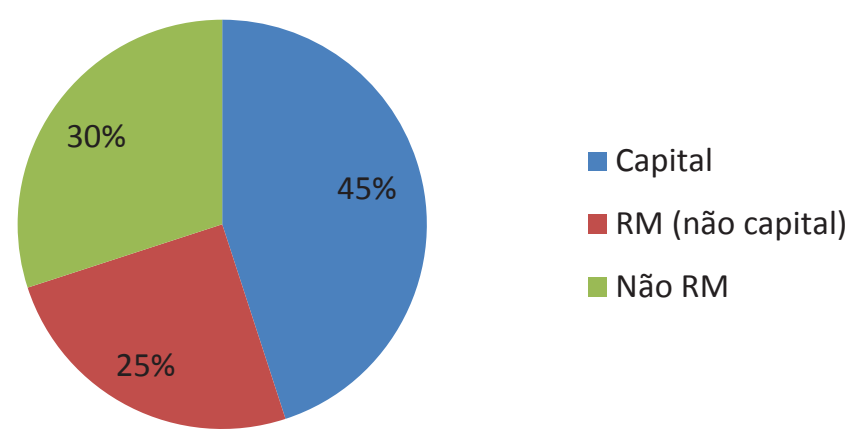

Fonte: Elaboração própria.

A amostra distribui-se nas diversas modalidades dos programas, descritas a seguir. A modalidade Construção em Terreno Adquirido pelo FDS (Fase 2) trata das áreas adquiridas por Compra Antecipada (Aquisição de Terreno e Elaboração de Projetos) e que já tiveram a sua segunda etapa contratada, possibilitando o início das obras de edificação. (Gráfico 6).

Gráfico 6 - Modalidades de contratação

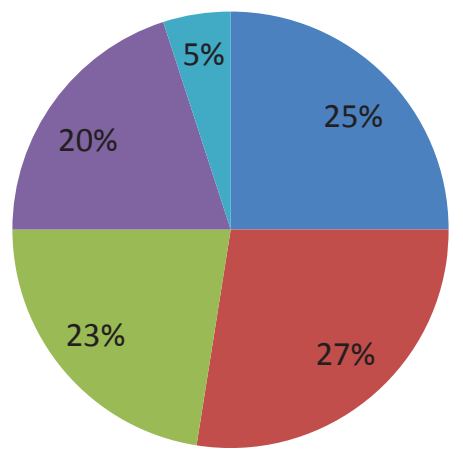

- Aquisição de Terreno e Elaboração de Projetos

- Aquisição e Construção

- Construção em Terreno de Terceiros

- Construção em Terreno Próprio

- Contrução em Terreno Adquirido pelo FDS (Fase 2)

Fonte: Elaboração própria. 
Também foram estudados empreendimentos em variadas etapas de implementação e que se depararam com as diversas fases dos programas, desde 2004. Há seis empreendimentos em fase de contratação, 14 já concluídos e os demais estão em diversas fases de construção ou elaboração e aprovação de projetos (Gráfico 7).

Gráfico 7 - Situação dos contratos

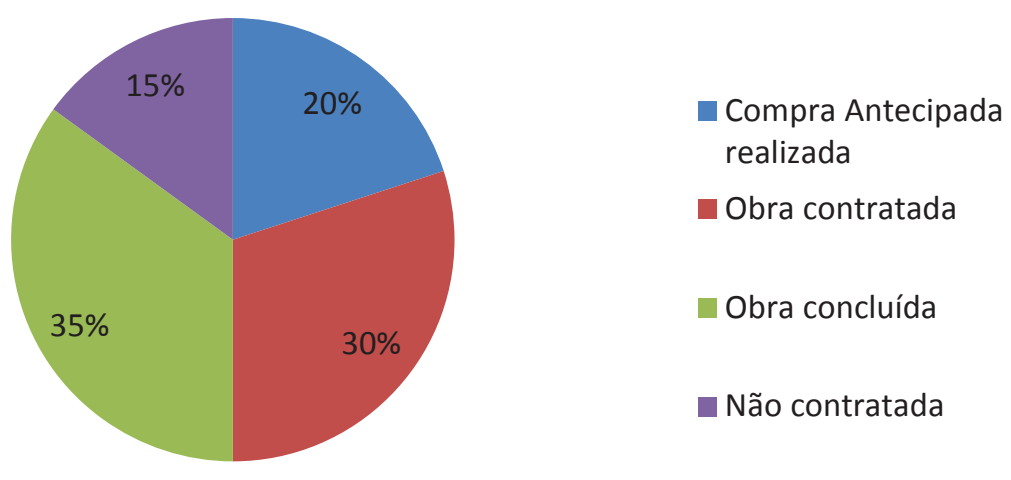

Fonte: Elaboração própria.

Quanto ao regime de construção, há clara opção pela administração direta e pela autogestão ${ }^{125}$, adotados por $82 \%$ dos empreendimentos analisados, com 33 casos e apenas sete optaram pela empreitada global. Essa informação contrasta com o panorama geral dos programas, em que a empreitada global é o regime de grande parte dos empreendimentos. Essa diferença acontece devido à escolha da amostra, que se deu dentro de movimentos ligados a entidades nacionais do movimento popular ou com trajetória em autogestão. A adoção da administração direta e da autogestão não necessariamente significa a realização de trabalho mutirante, em que os próprios participantes contribuem com parte da mão de obra necessária à edificação. Dos 33 casos, apenas 21 contaram com mão de obra mutirante. Os demais trabalharam somente com mão de obra contratada, direta ou indiretamente. (Gráfico 8).

${ }^{125}$ Até o MCMV 2 não havia o regime de Autogestão regulamentado nos normativos, no entanto, as entidades utilizavam a figura da Administração Direta, quando optavam por gerenciar a produção do empreendimento. 
Gráfico 8-Regimes de construção

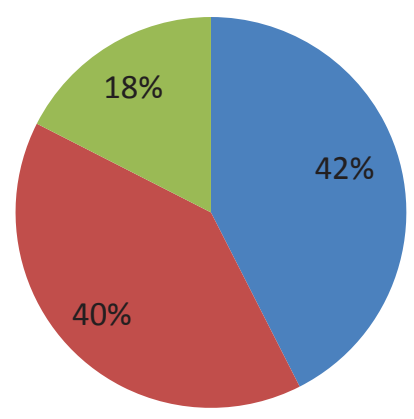

- Administração direta

- Autogestão

Empreitada Global

Fonte: Elaboração própria.

Articulado com o foco deste trabalho, que se deteve no aspecto fundiário dos empreendimentos, a ênfase está na verificação da forma de acesso aos terrenos para a construção dos empreendimentos.

A primeira questão levantada trata da forma de aquisição do terreno. Mais da metade das áreas (23 casos) foi adquirida no mercado, com recursos dos programas. Os demais foram doados ou cedidos por prefeituras e apenas três áreas disponibilizadas pelo governo federal (Gráfico 9). Apenas um terreno, no município de Diadema/SP foi adquirido pelos participantes organizados em associação, provavelmente porque os programas atendem às faixas de renda mais baixa, sem condições para tal aporte prévio. Nos casos de disponibilização de áreas por órgão público (prefeituras e SPU), há clara preferência pela doação, ocorrida em 12 casos, e apenas em quatro empreendimentos se utiliza a CDRU como forma de transferência.

Gráfico 9 - Forma de aquisição do terreno
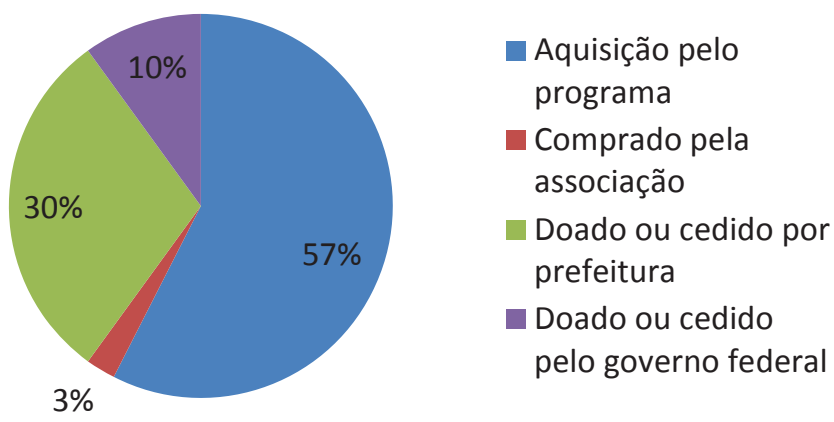

1. Fonte: Elaboração própria. 


\subsubsection{Doação de terras pelas prefeituras}

Nas primeiras discussões do PCS, havia a expectativa, por parte do governo federal, de que governos estaduais e municipais doassem terrenos para as entidades edificarem. De fato, isso ocorreu em pequenos municípios ou em lugares onde a política municipal de habitação estava mais consolidada e havia um compromisso com os movimentos sociais. 0 caso mais emblemático é o da cidade de Belo Horizonte/MG, onde o Orçamento Participativo da Habitação, que já havia destinado terrenos para as entidades, mas que encontrava dificuldades no financiamento da edificação, articulou sua estratégia ao PCS, repassando os terrenos e fazendo os aportes complementares para viabilizar os empreendimentos. Outro município pesquisado, Alfenas/MG, também contou com a doação de imóveis para o movimento popular viabilizar empreendimentos, articulado com a política municipal de habitação, que propunha a construção de pequenos conjuntos dentro da malha urbana da cidade.

No entanto, essa não foi uma experiência verificada em todo o País, no PCS ou no MCMV-E. Apesar da atuação dos movimentos nos conselhos locais de habitação e a pressão feita sobre as prefeituras, a falta de um estoque de terras nos municípios, influenciada inclusive pelo contingenciamento de recursos públicos para habitação do momento anterior, foi um dos primeiros obstáculos encontrados. Além disso, poucos municípios, até então, tinham apoiado propostas autogestionárias e estavam comprometidos com ela. Não se pode deixar de considerar também que muitas das entidades populares estão envolvidas em disputas políticas locais e são excluídas de qualquer ação dessas prefeituras.

Na cidade de São Paulo, por exemplo, a Cohab detinha algumas áreas remanescentes e, no início do MCMV, decidiu aportá-las ao programa, na modalidade das construtoras. A transação deveria ser feita pelo Fundo Municipal de Habitação e aprovada pelo Conselho Municipal, que tem maioria da sociedade civil. Como os movimentos apresentaram emenda ao voto, destinando parte das áreas para o MCMV-E, a Cohab simplesmente tirou o voto de pauta, aprovando sua proposta original na gestão seguinte, em nova composição política do Conselho. 
Nos casos em que as doações de terrenos foram levadas para a aprovação do Legislativo municipal, os representantes dos movimentos acompanharam todo o processo de tramitação. Foram realizados ações de convencimento e de pressão junto aos vereadores. Em Salvador/BA, o terreno do empreendimento Mar Azul só teve sua doação autorizada pela Câmara após vigílias e manifestações realizadas em diversas sessões. Em Suzano/SP, o movimento acompanhou todas as sessões de discussão do projeto de lei. Após os vereadores rejeitarem a proposta de doação da área para o PCS, diversas lideranças foram detidas pela Polícia Militar por manifestar-se de forma contrária.

Apesar de não haver restrição formal para a utilização de instrumentos de cessão de áreas públicas, como a Concessão de Direito Real de Uso (CDRU) e a Cessão de Uso Especial para fins de Moradia (Cuem), observou-se que essas figuras foram pouco utilizadas, tendo sido priorizado o instrumento da doação dos terrenos. A exceção ocorreu nos terrenos da Secretaria do Patrimônio da União, que, como se verá a diante, privilegiou a CDRU como instrumento de disponibilização. O que se percebe é a reafirmação da cultura que apenas valoriza a propriedade plena e desconsidera os avanços legais recentes.

\subsubsection{O Movimento vai ao Mercado}

Sem política fundiária nem apoio institucional para obter terrenos, restou às entidades lançar-se no mercado imobiliário para a aquisição de áreas. Se, em 2004, ano de lançamento do PCS, esse mercado estava pouco ativado, o que se viu nos anos seguintes foi o seu aquecimento gradativo. Moreira (2009, p.150) ressalta:

\footnotetext{
As terras disponíveis vão rapidamente para as mãos daqueles que tem reservas ou crédito fácil (pois apresentam garantias reais) e flexibilidade de negociação, enquanto os financiamentos públicos impõem uma lógica engessada e burocrática, dificultando ainda mais o acesso à escassa disponibilidade de terras para produção oficial de HIS.
}

A falta de terrenos e seu encarecimento são sentidos diretamente pelas entidades do movimento popular. O relato de Donizete Fernandes, coordenador da UNMP, à revista Caros Amigos, resume bem esse quadro: 
Na cidade de São Paulo, por exemplo, como as terras estão acabando, o que restam são pequenos espaços urbanos vazios. Tem bairros que já estão formados, inclusive na periferia, só que esse espaço está sendo disputado com a especulação imobiliária(...).

o Estatuto da Cidade dá um instrumento para os prefeitos cobrarem, por exemplo, o IPTU progressivo. Só que os prefeitos não usam essa lei porque têm medo, então, não cobram, por exemplo, o IPTU progressivo desse pessoal que está fazendo a especulação com receio de perder a eleição, ficar impopular.

No Jaraguá, a gente construiu muita moradia para a população com rendimento de até três salários mínimos. Só que, como o bairro possui boa infraestrutura, as classes altas, donas do dinheiro, estão chegando lá e disputando [espaço] com a gente. Estão comprando terras para vender moradia para uma faixa da população de rendimentos de seis a dez salários-mínimos.

A consequência dessa disputa com a especulação imobiliária, segundo afirma o representante da UNMP, é a elevação desenfreada do preço do metro quadrado na região. "Assim, teremos que construir em Francisco Morato, Caieiras, Franco da Rocha...", referindo-se a municípios metropolitanos mais afastados do Centro de São Paulo. “À medida que o governo não toma as rédeas, os trabalhadores são jogados para as periferias das periferias" (PARMESANNI, 2013, p. 3).

Isso tem levado as entidades a ficar com os terrenos que sobram no mercado, especialmente nos períodos do boom imobiliário, que ocorreu após o lançamento do programa MCMV. Lideranças do movimento, de modo irônico, qualificaram esse modelo como a "lógica da laranja madura"126, ou seja, os terrenos baratos e acessíveis para aquisição pelo movimento através dos programas sempre têm alguma restrição, seja por sua localização, características físicas, ou documentação, caso contrário, já teriam sido adquiridos pelo mercado.

Nesse contexto, forma-se uma cadeia predatória da terra: os terrenos que não servirem ao mercado de alto padrão ou renda média podem ser utilizados pelo segmento econômico, financiado pelo MCMV; os que não servirem a esse segmento podem ser destinados à Faixa 1, para ser operado pelas construtoras; os que ainda assim sobrarem podem ir para as associações. Fix (2011, p. 199) relata esse cenário em algumas capitais brasileiras.

\footnotetext{
${ }^{126}$ Refere-se à música de Ataulfo Alves, de 1966, com a seguinte letra: “Laranja madura, na beira da estrada, tá bichada, Zé, ou tem marimbondo no pé".
} 
O movimento de moradia geralmente assina uma carta de compromisso de compra do terreno e, com isso, ganha um prazo para aprovar o projeto e conseguir o financiamento. $O$ processo é lento e muitas vezes o prazo precisa ser renovado, o que não costumava ser problema até que a disputa com as construtoras se acirrasse. Uma das questões é que as empresas têm departamentos jurídicos capazes de resolver imbróglios que geralmente caracterizam os terrenos mais baratos na cidade. Com isso, conseguem comprar a preços baixos, resolver as pendências jurídicas e vender depois com sobre preço. Os movimentos, diferentemente, passam por uma via crucis e muitas vezes não conseguem viabilizar o projeto.

Poucas entidades tinham experiência na aquisição de terrenos e muito menos o mercado estava acostumado a lidar com esse ator. Um misto de desconhecimento da existência de programas públicos que financiavam os movimentos e de preconceitos, cevados por anos de conflitos em ocupações, fez com que os movimentos, muitas vezes, sequer conseguissem abrir negociações com imobiliárias e proprietários. Em negociação com um proprietário em São Paulo, uma entidade viu-se compelida a incluir uma cláusula incomum no termo de opção de compra e venda que assinaria com o proprietário: o compromisso de que, em momento algum, mesmo que o negócio não se concretizasse, o movimento ocuparia o terreno ${ }^{127}$.

${ }^{127}$ Empreendimentos Florestan Fernandes e José Maria Amaral, Zona Leste, São Paulo/SP. 
Figuras 39, 40, 41 e 42 - Visita para aprovação e realização de estudo de terreno para MCMV Entidades - São Paulo-SP - 2009
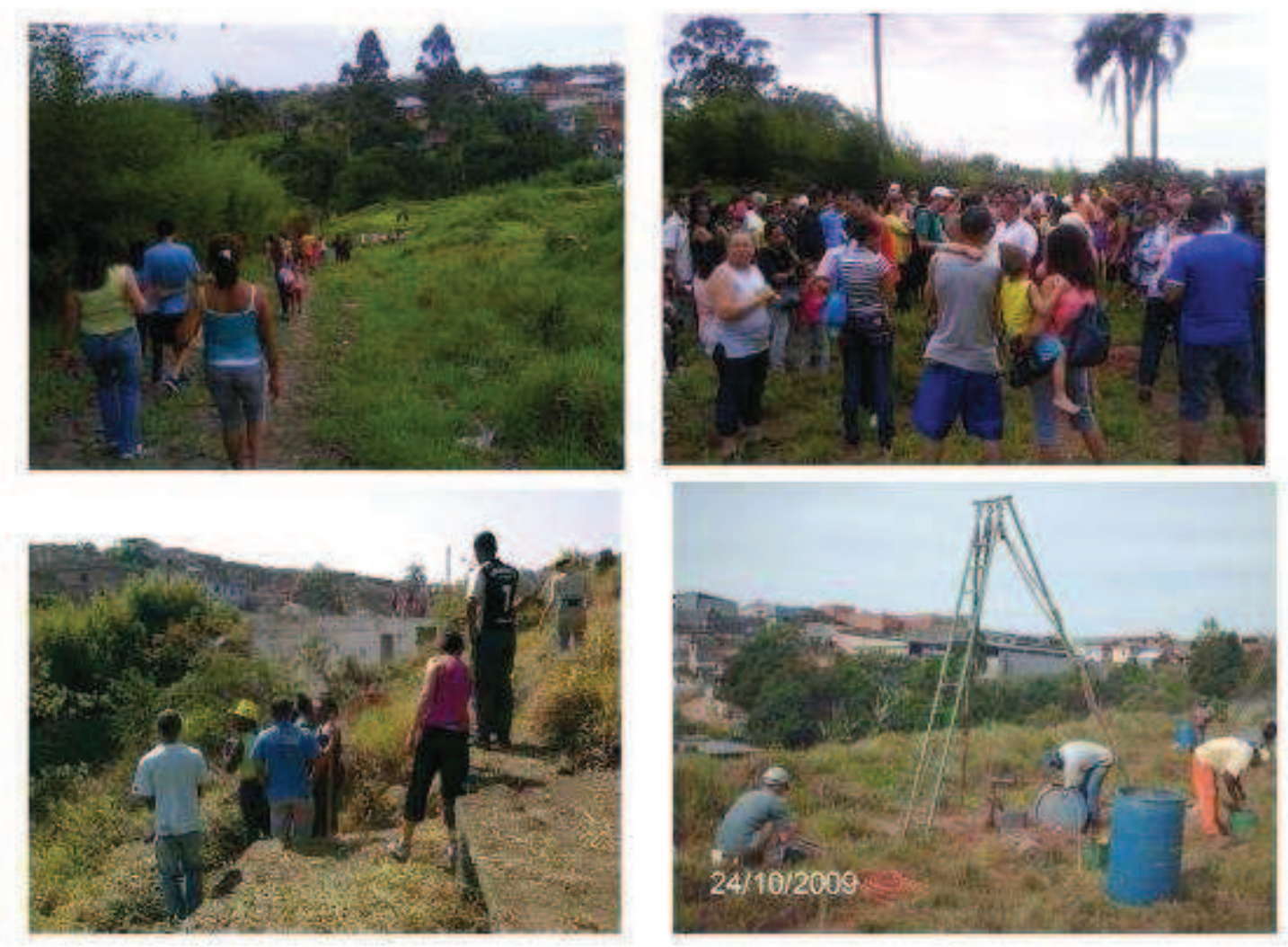

Fonte: A autora

Sem capital, nem suporte institucional, as entidades peregrinam por imobiliárias e proprietários até conseguirem um terreno que tenha viabilidade técnica, preço acessível e a disponibilidade de ser adquirido, após todo o desenvolvimento de projeto, aprovações nos órgãos de licenciamento e enquadramento nas regras dos programas.

Em geral, esses processos têm levado mais de um ano, com alguns casos, que foram levantados nesta pesquisa, chegando até a quatro ou cinco anos. Em decorrência disso, diversas entidades já perderam áreas identificadas, onde já haviam investido recursos para projetos e aprovações. Com o mercado aquecido, o prazo de opção de compra tem ficado cada vez menor, prejudicando ainda mais as entidades.

Nos casos estudados, verificou-se que, em função desses prazos alongados, também ocorre a solicitação de reajuste por parte dos proprietários, gerando assim a necessidade de nova avaliação do imóvel e readequação dos orçamentos. O terreno do empreendimento Zorilda, em Suzano/SP, sofreu sucessivos reajustes, que alcançaram $47 \%$ do valor inicial, durante os cinco anos de negociações; esses valores foram incorporados ao orçamento, o 
que foi possível devido aos novos valores quando da aprovação do MCMV-E. Quando isso não é possível, o terreno é descartado - e com isso todo o trabalho realizado anteriormente - ou as próprias famílias arcam com a diferença, como ocorreu no empreendimento Alexius Jafet, em São Paulo.

Há casos positivos, como os de Eldorado Oeste, em Goiânia/GO, e de Vila de São Miguel, em Itaquaquecetuba/SP, nos quais a avaliação de mercado feita pela Caixa foi inferior ao valor proposto pelo proprietário. Nesses casos, a avaliação pressionou os proprietários a diminuírem o preço. Isso também justifica uma solicitação constante dos movimentos, para que a Caixa, o Ministério e a prefeitura apoiem as entidades nas negociações no mercado, trazendo às entidades reconhecimento junto a esse ator que o desconhece ou o discrimina.

A alternativa adotada por algumas entidades tem sido propor aos proprietários dos imóveis uma Opção de Compra Onerosa, em troca de prazos mais longos de vigência, ou seja, a entidade paga um percentual do valor da área na assinatura da opção de compra e quando da aquisição do terreno, o financiamento paga o valor restante. Caso a contratação não se concretize no prazo de vigência da opção de compra, a entidade perde o valor adiantado. Esse formato tem exacerbado os riscos das entidades e dos participantes, que, na maioria das vezes, têm que se cotizar para fazer o pagamento do percentual adiantado. Novamente, todo o risco fica com a parte mais frágil do processo. A entidade corre não somente o risco financeiro de perder o dinheiro, mas da credibilidade junto à comunidade, ficando sujeita, inclusive, a denúncias na mídia ${ }^{128}$, processos judiciais e representação do Ministério Público.

Há casos excepcionais, como o ocorrido no Empreendimento Mangueiras, localizado em Salvador/BA. Após quatro anos, com diversas renovações da opção de compra, enquanto a entidade vencia as etapas de licenciamento do projeto, o proprietário decidiu não mais renová-la, encerrando as negociações com a entidade e negociando o terreno com uma construtora privada. Há que se notar que, durante o período, a região do entorno do terreno recebeu diversos investimentos públicos e privados, tendo sido valorizada. Após tentativas

\footnotetext{
128 Reportagens na mídia, no final de 2011, denunciavam a cobrança de taxas para o MCMV por parte de entidades. O que há de se diferenciar, no entanto, são cobranças abusivas e com fins espúrios, com a necessária contrapartida financeira ou não para a viabilização de empreendimentos.
} 
de retomada das negociações, inclusive com incremento no preço, a entidade decidiu tomar duas medidas: ação judicial e ocupação do terreno.

A ação judicial pedia, de forma liminar, o embargo da matrícula do imóvel e visava demonstrar que o proprietário havia agido de má-fé, já que a negociação com o outro comprador estava em andamento, ainda durante a validade da opção de compra do movimento, e que as famílias participantes do movimento teriam a expectativa de direito frustrada pela desistência do proprietário. A combinação da pressão e o embargo da matrícula decidida por liminar forçaram a retomada das negociações e o terreno foi, enfim, comprado pelo movimento, através do PCS.

Uma das preocupações constantes relatadas nas entrevistas foi o prazo necessário para a conclusão das análises e aprovações para a contratação e aquisição do terreno. Dentre os empreendimentos com aquisição de terreno financiada pelos programas, cerca de $80 \%$ levaram mais de um ano para concluir o processo. Nos casos estudados de compra antecipada, curiosamente, o tempo para aquisição das áreas não foi menor do que os demais, como é o objetivo da modalidade. Uma hipótese é que são os primeiros empreendimentos da modalidade, ainda com muitas situações imprevistas e mudanças de normativos. (Gráfico 10).

Gráfico 10 - Prazo para a aquisição do terreno

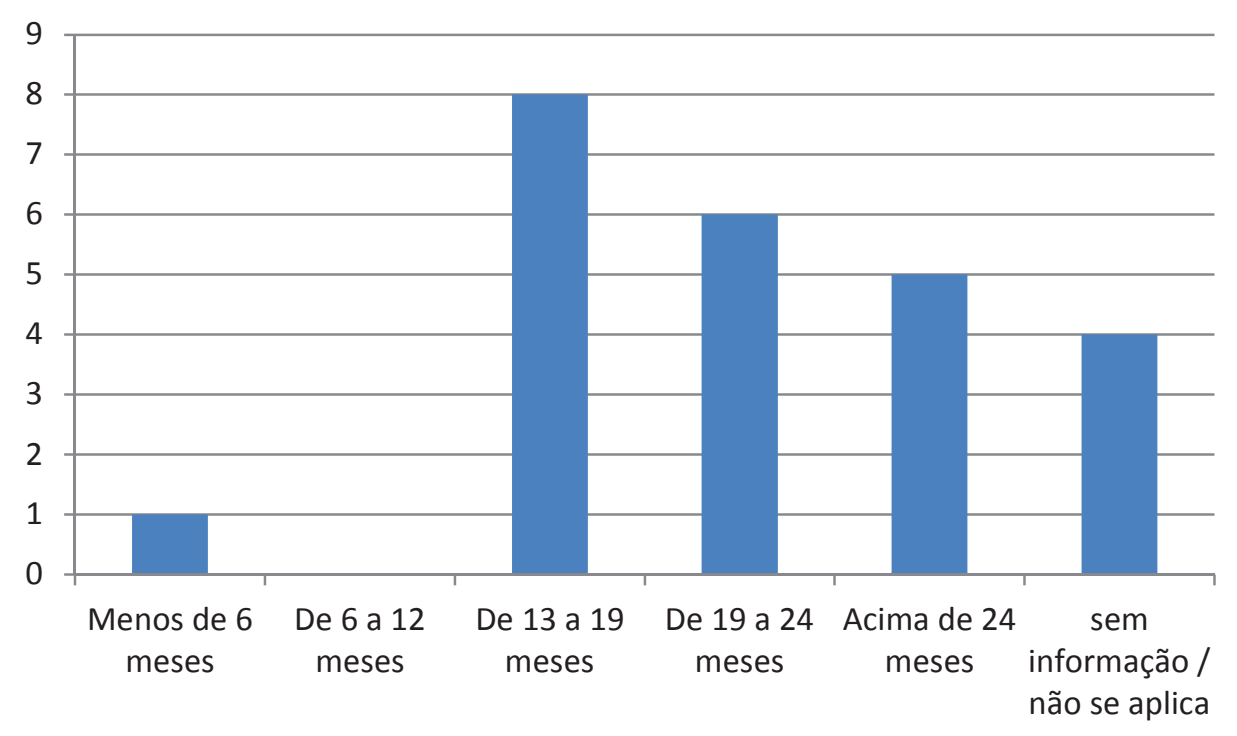

Fonte: Elaboração própria. 
Para identificar os terrenos para os empreendimentos, $42 \%$ dos casos tiveram a intermediação de uma imobiliária ou corretor de imóveis, o que demonstra essa busca no mercado formal. Foram relatados ainda contatos informais com vizinhos, caseiros ou terceiros, na negociação dos terrenos. (Gráfico 11).

A maioria dos relatos indicou também que, antes de viabilizar a compra do terreno contratado, vários outros foram vistoriados, negociados e até apresentados formalmente à Caixa para aquisição, porém foram inviabilizados devido a preço, pendências documentais ou de tributos, ou devido à demora para a conclusão, o que fez o proprietário desistir da venda, fato que recebeu destaque nas entrevistas.

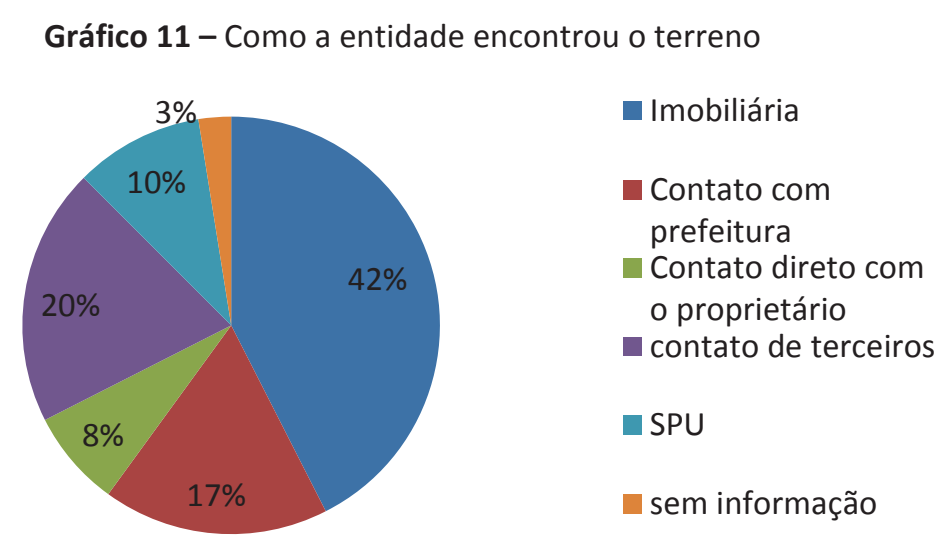

Fonte: Elaboração própria.

Também foi observado que a maioria dos terrenos, públicos e privados, foram viabilizados em negociações com órgãos públicos ou relação comercial com o proprietário ou imobiliária. Apenas 7\% dos imóveis estudados foram ocupados pelo movimento, como forma de pressão, antes da contratação. As ocupações de imóveis federais ou órgãos públicos, como a Caixa Econômica Federal, para pressionar o governo para introduzir mudanças ou agilizar os programas foi estratégia utilizada em diversas ocasiões. (Gráfico 12). Foram relatadas outras formas de pressão, como manifestações, vigílias e acampamentos, utilizadas como ferramentas de luta para viabilizar a aquisição dos terrenos. Os alvos prioritários e objetivos identificados foram: 
- Prefeituras - aprovação dos projetos, oficialização de vias ou aportes de infraestrutura ou recursos financeiros;- Ministério das Cidades e a Caixa - alteração de normativos e agilização de análises;

- Câmaras Municipais - aprovação de doação de terrenos e alteração de legislação municipal;

- Concessionárias - aprovação de projetos de água, esgoto e energia;

- Governos estaduais - aporte financeiro;

- SPU e INSS - destinação de imóveis ociosos para HIS.

Gráfico 12 - Ocupação no terreno

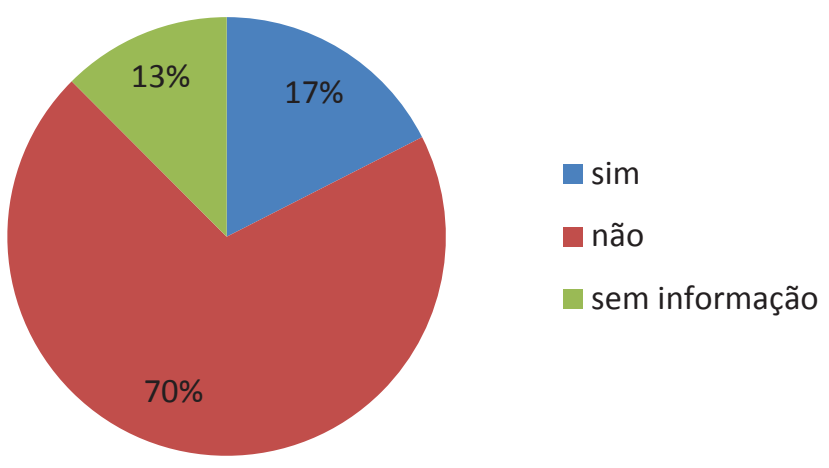

Fonte: Elaboração própria

Por fim, foram observados os gastos realizados pela entidade para a efetivar a contratação e/ou aquisição do terreno. Nesses custos, estão incluídos estudos e projetos, taxas públicas e cartorárias, reprodução de documentos e plantas, apoio administrativo para a elaboração da proposta, assessoria de engenharia e arquitetura, jurídica e social. Não foram aqui considerados os custos de mobilização da demanda, que já fazem parte da atuação dos movimentos, mas apenas os gastos com a proposta.

Em 17\% dos casos, as entidades afirmam não registrar gastos ou que foram inferiores a $\mathrm{R} \$ 5$ mil. Esses casos coincidem com os empreendimentos que tiveram apoio institucional, especialmente da prefeitura. Os demais relatam gastos mais altos, arcados, em sua maioria, pelas próprias famílias participantes do empreendimento. Em apenas cinco casos foram 
relatados apoios de ONGs nacionais ou internacionais. Na maioria dos empreendimentos, foram identificados "contratos de risco", em que as assessorias técnicas aceitaram receber o valor de projeto após a contratação.

O Gráfico 13 demonstra que, além da capacidade de mobilização e pressão, a entidade, para acessar os recursos dos programas federais, necessita ter capacidade empreendedora e mobilizadora de recursos, excluindo dessa possibilidade as pequenas organizações.

Gráfico 13 - Gastos realizados pela entidade até a contratação
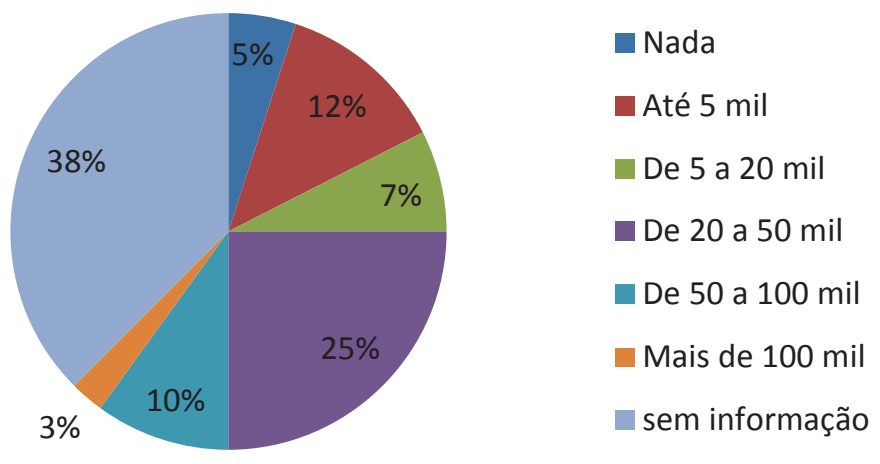

Fonte: Elaboração própria.

Nos 24 casos em que houve aquisição de terrenos, verificou-se o valor da compra e sua relação com a proposta a ser produzida. A primeira constatação foi de que os terrenos com o valor de metro quadrado mais caro destinaram-se à construção de apartamentos e os terrenos com valores mais baixos à de conjuntos horizontais. (Gráfico 14).

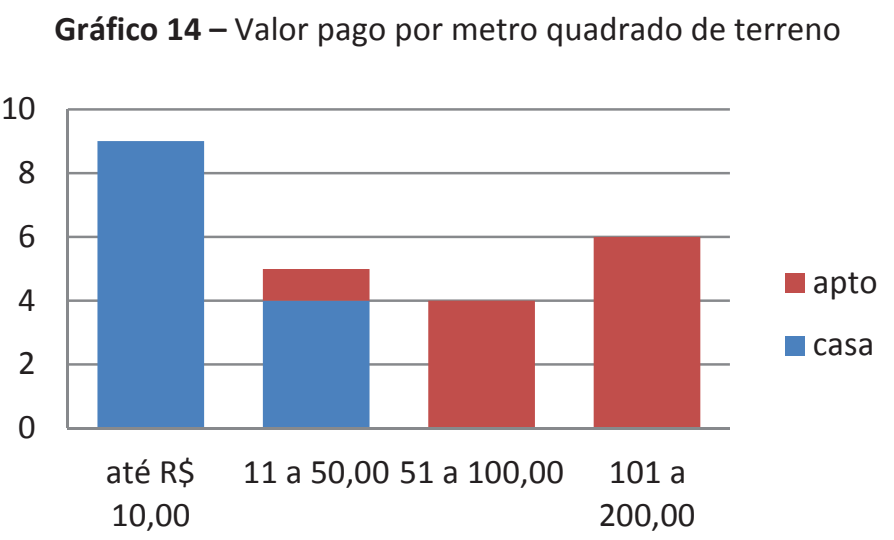

Fonte: Elaboração própria. 
No entanto, a informação sobre o valor do metro quadrado não pareceu muito relevante, visto que o período abrangido é de cerca de 6 anos e as realidades locais muito diversas, bem como o aproveitamento dos terrenos. Assim, pareceu mais significativo aferir quanto o valor do terreno incidiu no valor total do financiamento. Os programas, em duas diferentes etapas, definiram um valor teto para as unidades, de acordo com o estado e o porte do município. Além disso, no MCMV-E estabeleceu-se um teto de $15 \%$ do valor da unidade para aquisição de terrenos.

Essa norma poderia ser excepcionada mediante justificativa técnica apresentada pela entidade. O que foi verificado é que a maioria dos empreendimentos teve incidência próxima ao teto permitido, independentemente de se tratar de conjuntos de casas ou de apartamentos, ou seja, o valor do teto do financiamento determina o mercado. (Gráfico 15).

Gráfico 15 - Relação entre valor do terreno e valor do empreendimento (\%)

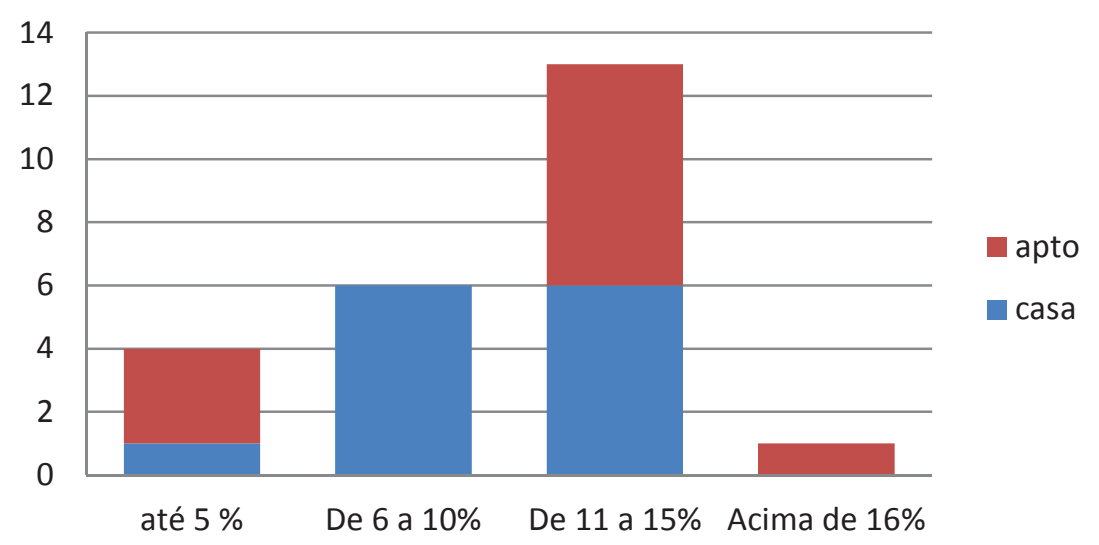

Fonte: Elaboração própria.

Também foi verificado o valor da fração ou lote do terreno em Reais, nesses empreendimentos. Enquanto em quase $70 \%$ dos empreendimentos horizontais o valor por família foi inferior a R\$ 4 mil, nos verticais há casos em todas as faixas de preço. (Gráfico 16). 
Gráfico 16 - Valor da fração por UH (R\$)

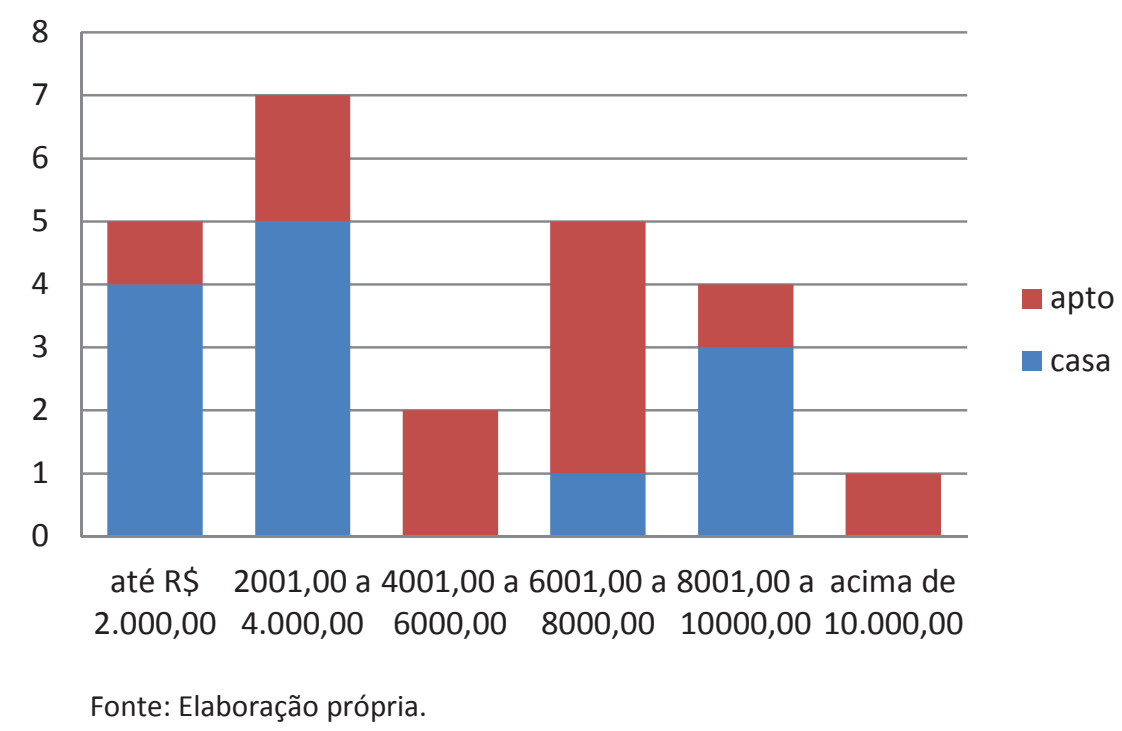

Também foi observado o tamanho da fração de terreno destinado a cada família, na totalidade dos empreendimentos analisados. Obviamente, os empreendimentos verticalizados tiveram frações menores, mas os empreendimentos horizontais variaram de cerca de 100 a 450 metros quadrados de tamanho, demonstrando diversidade na tipologia. Uma das hipóteses verificada nos casos de frações maiores refere-se a exigências de caráter ambiental, como área para reserva legal e APPs de curso d'água ou nascente. Cinco empreendimentos verticais, com frações abaixo de $50 \mathrm{~m}^{2}$ contam com edifícios de mais de dez andares, com elevador, demonstrando a necessidade de privilegiar a verticalização para melhor aproveitar as áreas e viabilizar financeiramente o empreendimento. (Gráfico 17).

Gráfico 17 - Tamanho da fração de terreno por UH $\left(\mathrm{m}^{2}\right)$

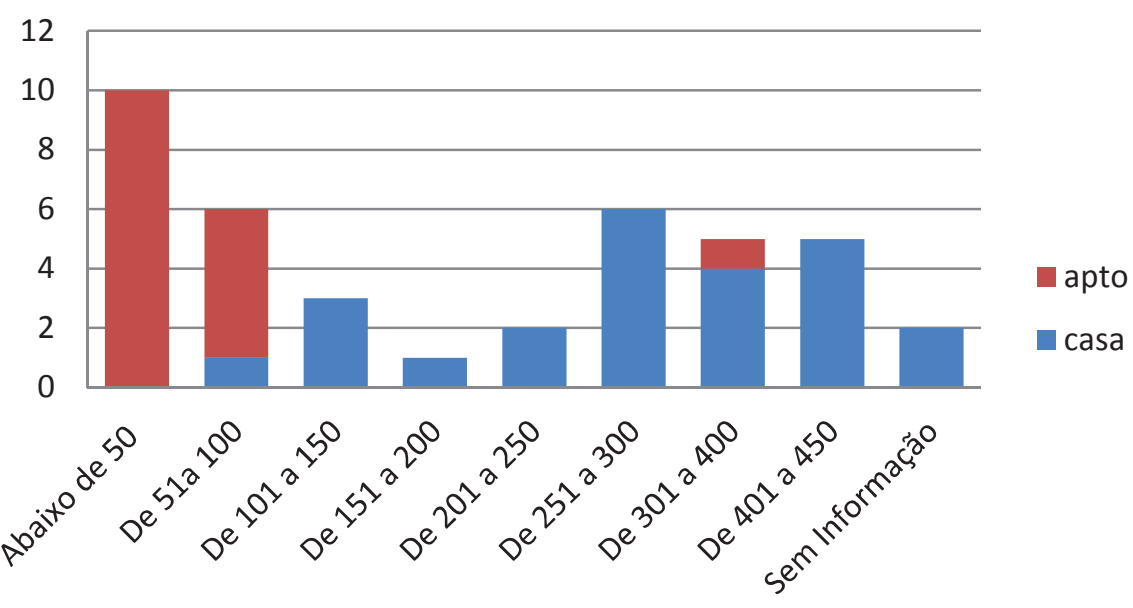

Fonte: Elaboração própria. 
Dos dez casos com frações menores do que $50 \mathrm{~m}^{2}$, seis se localizam na cidade de São Paulo e um em outro município dessa Região Metropolitana, na qual os preços de terreno têm sido maiores. Em cinco desses casos, a opção encontrada para viabilizar a proposta foi a construção de edifícios com mais de dez pavimentos e com utilização de elevadores, tipologia pouco comum em empreendimentos de habitação popular. Ainda é preciso destacar que, no Estado de São Paulo, acordo firmado com o governo estadual, aporta até R\$ 20 mil por unidade da MCMV.

Figura 43 - Projeto José Maria Amaral e Florestan Fernandes - MCMV-E - São Paulo-SP- 2010

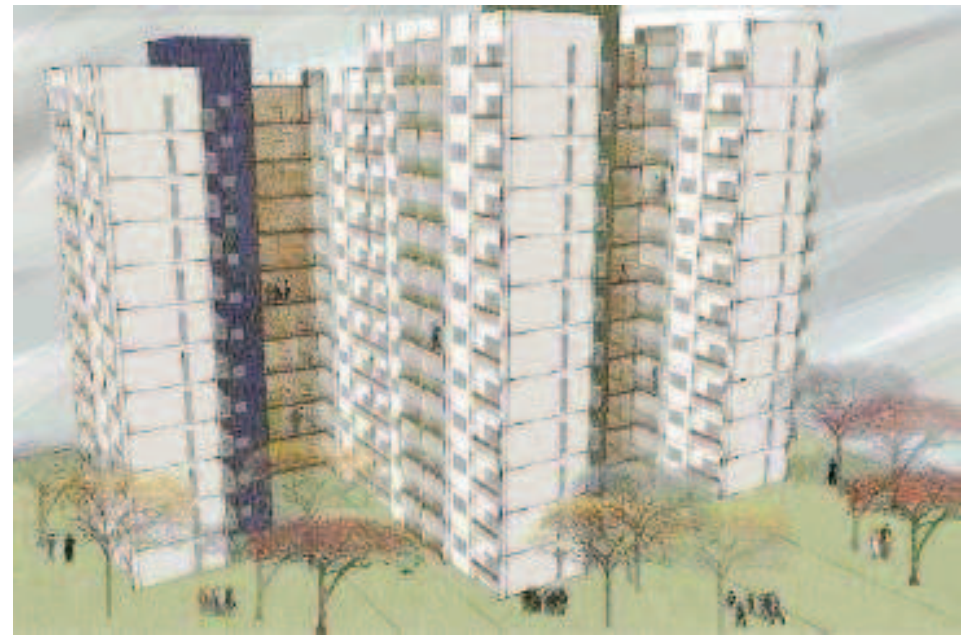

Fonte: Ambiente

Ainda com fração inferior a $50 \mathrm{~m}^{2}$, encontra-se o empreendimento Vila Patrimonial, do PCS, em São Paulo, que se encontra em bairro popular totalmente ocupado, em um vazio urbano. O empreendimento tem 96 apartamentos, em prédios de cinco pavimentos e centro comunitário, em um terreno de pouco mais de $4.000 \mathrm{~m}^{2}$ de alta declividade, demonstrando alto aproveitamento, com qualidade de projeto e boa inserção urbana. 
Figuras 44, 45 e 46 - Implantação, edificação e entorno do empreendimento V. Patrimonial - São Paulo/SP - 2012
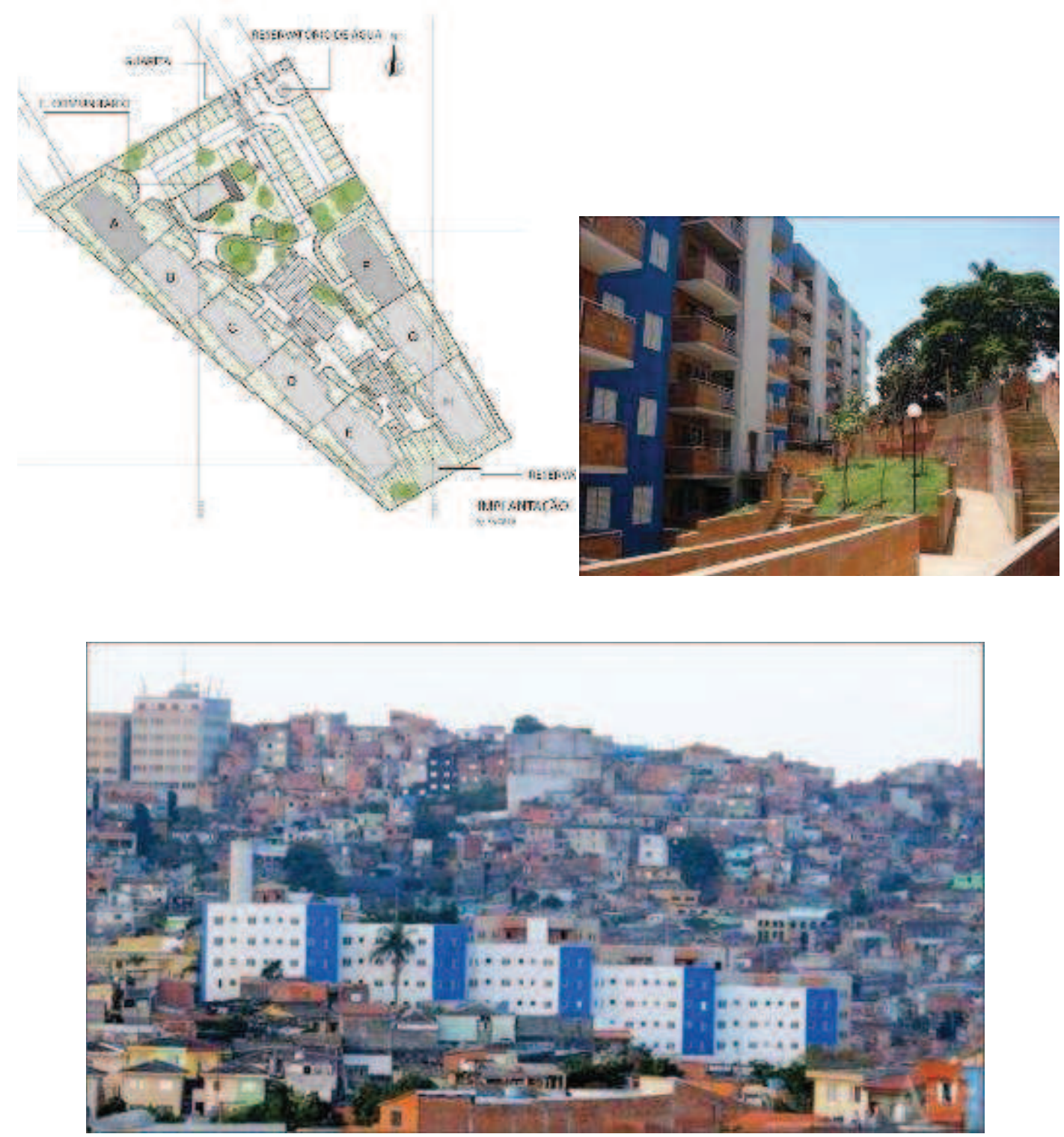

Fonte: Ambiente Arquitetura 


\subsubsection{Localização e Infraestrutura}

Devido às exigências dos programas, a maioria das áreas já contava com algum tipo de infraestrutura pré-existente, especialmente de água e energia. No entanto, o item esgoto não foi verificado em todos os empreendimentos, já que o programa prevê, na ausência de rede coletora, a adoção de solução alternativa, desde que aceita pelos órgãos locais. Em alguns casos foi necessário reforçar a rede ou construir Estações de Tratamento de Esgoto (ETEs) independentes. Embora o programa preveja a construção da ETE e sua doação à concessionária, este tem sido um ponto de conflito em alguns estados, como São Paulo.

Além disso, é considerada infraestrutura incidente, ou seja, passível de financiamento, aquelas inseridas dentro da poligonal do empreendimento. Qualquer infraestrutura externa necessária deverá ser financiada por contrapartida de órgão público, ou da concessionária, ou aportada pelos participantes do empreendimento. Isso tem inviabilizado a contratação de alguns empreendimentos, como o Esmeralda, da Praia Grande/SP, que necessita da construção de 500 metros de rede de esgoto para a conexão ao sistema da concessionária, mas esta não assumiu, até o momento, a sua execução. (Gráfico 18).

Gráfico 18 - Infraestrutura preexistente no entorno do terreno

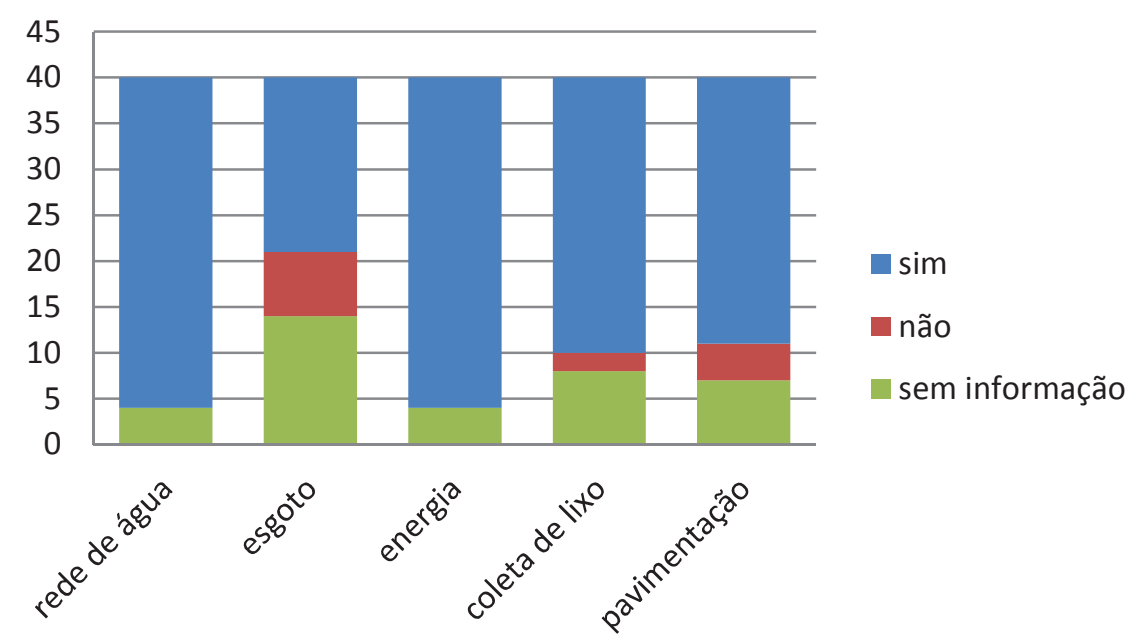

Fonte: Elaboração própria. 
Mesmo quando existe o compromisso formal da prefeitura, ou concessionária, com a implantação de infraestrutura externa, ou interna, não há, muitas vezes, compatibilidade de cronogramas, já que o empreendimento está descolado da política local de desenvolvimento urbano, gerando conflitos e atrasos nas aprovações. Em Apucarana/PR, a construção do empreendimento Orlando Bacarim já estava concluída, mas o atraso da concessionária de energia impedia a entrega das unidades, fato que só foi solucionado após acampamento dos participantes do empreendimento na sede da empresa de energia.

A maioria dos empreendimentos estudados relata a existência de escola de ensino fundamental nas proximidades, com até 1 quilômetro de distância. Apenas em dois casos foi relatada a necessidade de utilizar transporte para esse deslocamento. A situação é menos favorável no que diz respeito à existência de creches e de escolas de ensino médio, visto que $25 \%$ dos entrevistados relatam a inexistência desses equipamentos no entorno. Em $25 \%$ dos casos, também foi relatada dificuldade de acesso a equipamentos de saúde, como Unidades Básicas. Outros equipamentos citados em alguns empreendimentos foram Centro de Referência de Assistência Social, Centro de Atenção Psicossocial, posto policial, campo de futebol, biblioteca, parque e Centro de Convivência do Idoso.

Quanto ao transporte público, a maioria relatou a existência de linhas regulares de ônibus na proximidade do empreendimento. Apenas em dois casos foi constatada a ausência de linhas regulares, com a existência de apenas transporte "alternativo" - vans ou mototáxis - e em outros três empreendimentos a parada de ônibus fica a cerca de 1 km de distância. Apesar da existência de linhas regulares, 22 entrevistas relataram a utilização de mototáxis, demonstrando a precariedade do transporte público.

A maioria dos entrevistados afirmou existir comércio local próximo ao empreendimento. A maioria também citou o setor de comércio e serviços como as oportunidades de emprego mais próximas para os futuros moradores. Apenas os empreendimentos localizados na Região Metropolitana de São Paulo ( $A B C D$ e Alto Tietê) e Goiânia/GO citaram oportunidades em indústrias da região. Em Manaus/AM, há previsão de um polo industrial próximo ao empreendimento no plano diretor, mas ainda sem prazo de implantação. A agricultura foi citada como responsável por postos de emprego apenas no empreendimento de Apucarana/PR. 
Figura 47, 48 e 49 - Localização Mutirão Barra do Jacaré e Vale das Flores - São Paulo-SP e Parque das Aguas PCS - Ipatinga-MG
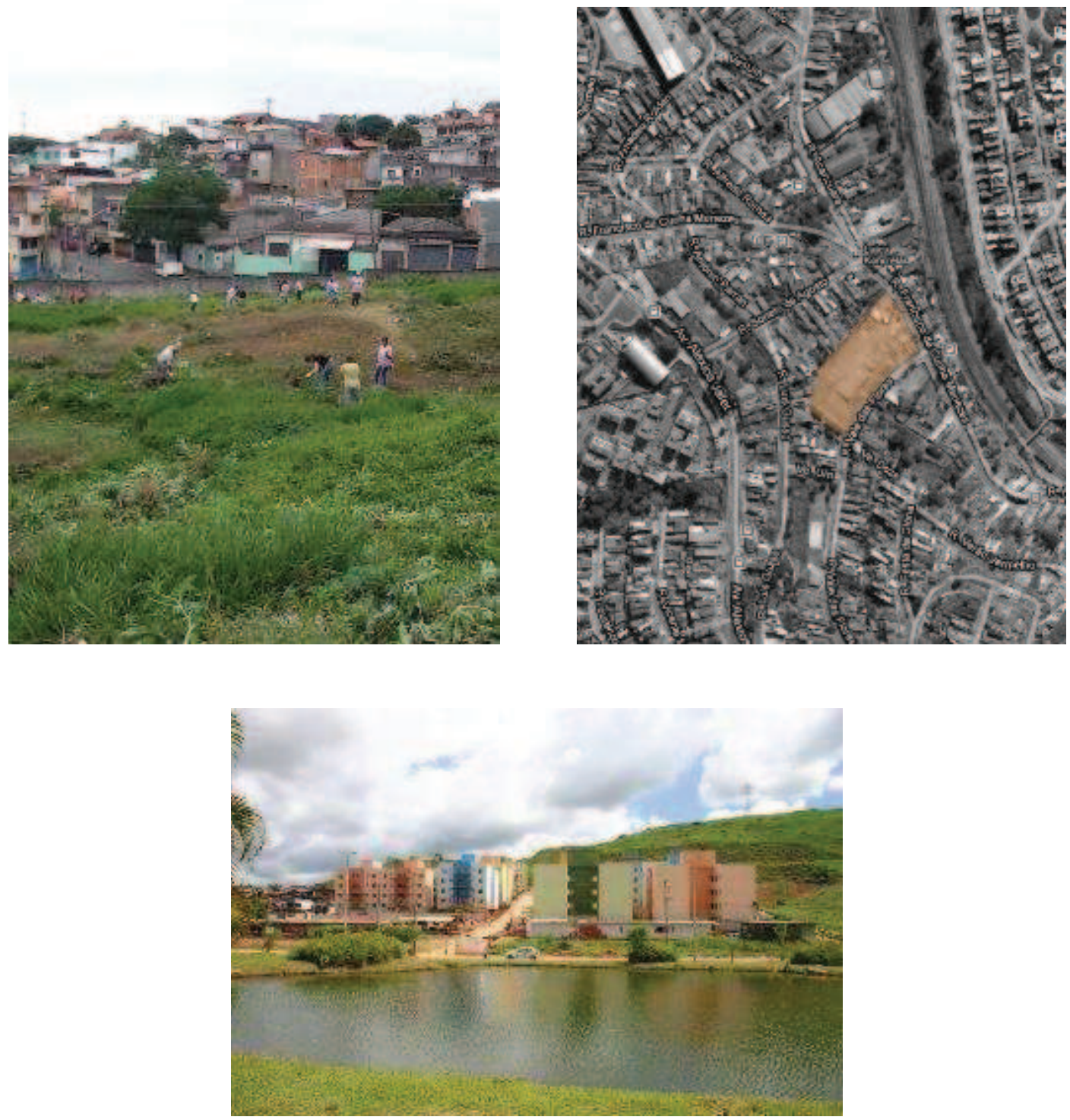

Fontes: Acervo Mov. Sem Terra Zona Oeste e Associação Habitacional de Ipatinga

No Anexo 3, é retratada a localização de 20 empreendimentos em seis municípios. Neles se confirma a inserção periférica da maioria dos empreendimentos, com algumas exceções. Além da distância em relação ao centro do município, também foram observadas sua contiguidade ou não com a malha urbana e relação com os bairros já existentes. 


\subsubsection{Aprovação e Licenciamento}

A questão das aprovações e licenciamentos também é prática nova para a maioria das entidades e suas assessorias técnicas. Diversos programas anteriores não tiveram essa exigência ou, melhor, por não ter sido exigida a terra regularizada, sequer chegaram à fase de aprovação dos parcelamentos ou das edificações. As aprovações davam-se no próprio órgão financiador, como no caso da CDHU. No caso do PCS e do MCMV-E, como já foi apresentado, o parcelamento e o projeto do conjunto habitacional devem ser previamente aprovados pelos órgãos licenciadores, conforme a legislação municipal e estadual incidente. Além disso, diversas entidades relataram dificuldades com esses órgãos, pois seus projetos eram preteridos nas análises em favor de grandes empreendimentos ou empreendimentos de alto padrão. Também foram relatados casos de cobrança de propina para a aprovação ágil de projetos, como prática usual em diversos órgãos públicos.

Em poucos casos foi relatada a existência de algum procedimento específico para a aprovação de empreendimentos de interesse social, caindo na "vala comum" das aprovações. Em alguns casos, quando se percebe a parceria entre o movimento e o município, é relatada a intervenção de gestores públicos para agilizar o processo. Há episódios, no sentido contrário, de que, cansados de esperar pelo trâmite, os movimentos realizaram manifestações públicas, exigindo a aprovação do empreendimento.

Assim como no MCMV destinado às construtoras, o modelo de financiamento também induziu que a maioria dos empreendimentos do PCS e MCMV-E fosse aprovada como condomínio, sejam as tipologias horizontais ou verticais, já que a aprovação de condomínios tem se demonstrado mais ágil do que a de loteamentos e com menores exigências, especialmente no que diz respeito à doação de áreas para o município. Percebese aí a lógica equivocada da incidência do valor da terra no financiamento: tratada como promotora privadas, no caso de loteamento, a entidade seria responsável por doar terreno para equipamentos públicos em vez de ter ação articulada com o município.

Quanto à tipologia dos empreendimentos analisados, 16 são conjuntos de apartamentos em condomínio e os demais 24 são empreendimentos horizontais, com casas ou sobrados. Nestes, a figura de parcelamento principal adotada é o loteamento, enquanto 
que há três condomínios horizontais e quatro empreendimentos não informaram. Além disso, 36 empreendimentos, ou 90\% da amostra, afirmaram ter equipamento comunitário construído ou previsto dentro do conjunto, construídos com recursos do FDS, demonstrando a preocupação com a posterior organização comunitária.

No quesito zoneamento, $75 \%$ dos terrenos dos empreendimentos encontram-se em Zeis. Em quatro casos, em São Luís/MA e Suzano/SP, foi relatada a mudança de zoneamento provocada pela necessidade de aprovação do empreendimento. O melhor aproveitamento do terreno foi a principal vantagem apontada pelas entrevistas para esse zoneamento. No entanto, informam não ter notado qualquer influência do instrumento na negociação para a aquisição do terreno e citam que muitos dos proprietários sequer sabiam que seu terreno estava demarcado como Zeis ou o que isso impactava na sua utilização. As entidades também afirmaram que nenhum outro instrumento urbanístico previsto no Estatuto da Cidade incidiu sobre as áreas utilizadas.

Outro empecilho encontrado foi a divergência encontrada nos diferentes órgãos licenciadores. A aprovação em órgãos ambientais e sua maior incidência nos últimos anos trouxeram não somente o alongamento dos prazos, mas também regras pouco claras para a aplicação da legislação. Em um dos casos estudados, o Zorilda, na cidade de Suzano/SP, o órgão ambiental estadual deu três diferentes interpretações para a exigência de reserva legal interna ao conjunto. Com isso, a entidade teve que refazer o projeto e perdeu cerca de $10 \%$ das unidades previstas quando da primeira análise do projeto.

A interpretação dos critérios e o grau de aplicação das normas ambientais podem variar de localidade para localidade, com maior ou menor rigor ou, ainda, com conflitos entre os próprios órgãos responsáveis. No empreendimento João do Vale, no Município de São Luís/MA, a prefeitura aprovou o projeto, a CAIXA comprou o terreno e contratou a obra em um local, aonde, depois da obra iniciada, foi constatado que se tratava de Zona de Preservação Ambiental. Para a continuidade do empreendimento, a prefeitura teve que enviar projeto de lei à Câmara Municipal para modificar o zoneamento, transformando-a em Zeis e regularizar um empreendimento já em obras.

Além do enquadramento na legislação municipal e estadual, os projetos também são analisados pela CAIXA que verifica o enquadramento nas regras do programa. O MCMV 
adota o conceito de "especificação mínima" para os projetos a serem financiados pelo programa, com diversos quesitos a serem atendidos na unidade habitacional e na implantação dos conjuntos. Apesar de ser qualificado como preocupação com a habitabilidade dos conjuntos, os movimentos classificaram esse processo como "dupla aprovação", exigindo uma sintonia inexistente entre os órgãos municipais e o programa federal.

Essa postura privilegia a repetição de projetos, prática comum nas construtoras e que desconsidera as características regionais e da demanda e dificulta a construção coletiva de projetos proposta pelas entidades autogestionárias. As entidades são orientadas por técnicos da Gidur a "não inventar", segundo uma liderança ${ }^{129}$, e assim ter mais agilidade na análise. Dessa maneira, ratifica-se a monotonia dos conjuntos habitacionais tanto na tipologia das habitações, quanto na forma de implantação. Mesmo nesse contexto, entidades e assessorias têm apresentado alternativas e enfrentado a resistência para a sua aprovação

Os movimentos, por diversas vezes, têm solicitado à CAIXA e ao MCidades o apoio junto aos órgãos locais de licenciamento. Como se tratam de empreendimentos pulverizados na malha urbana ou em suas bordas, dificilmente essas propostas relacionam-se com o planejamento urbano das cidades, tampouco com os instrumentos urbanísticos existentes.

Apesar de muitas entidades não terem informado quais os prazos necessários para as diversas aprovações que viabilizam os empreendimentos, verificou-se que a maioria dos casos relata prazos inferiores a seis meses para cada uma das diversas aprovações, enquanto que o processo de aprovação do projeto de edificação nas prefeituras é o que apresenta prazos maiores, superiores a um ano. Nem todos os empreendimentos necessitaram aprovar - parcelamento, visto que se tratava de condomínios ou, como no caso dos empreendimentos Florestan Fernandes e José Maria Amaral, o desdobro foi aprovado de forma simultânea à aprovação das edificações, modelo que se repete nos três empreendimentos Alexius Jafet. Apenas 13 empreendimentos relataram a exigência de aprovação em órgão ambiental. (Gráfico 19).

\footnotetext{
${ }^{129}$ Depoimento informal à autora.
} 
Gráfico 19 - Prazos para licenciamento

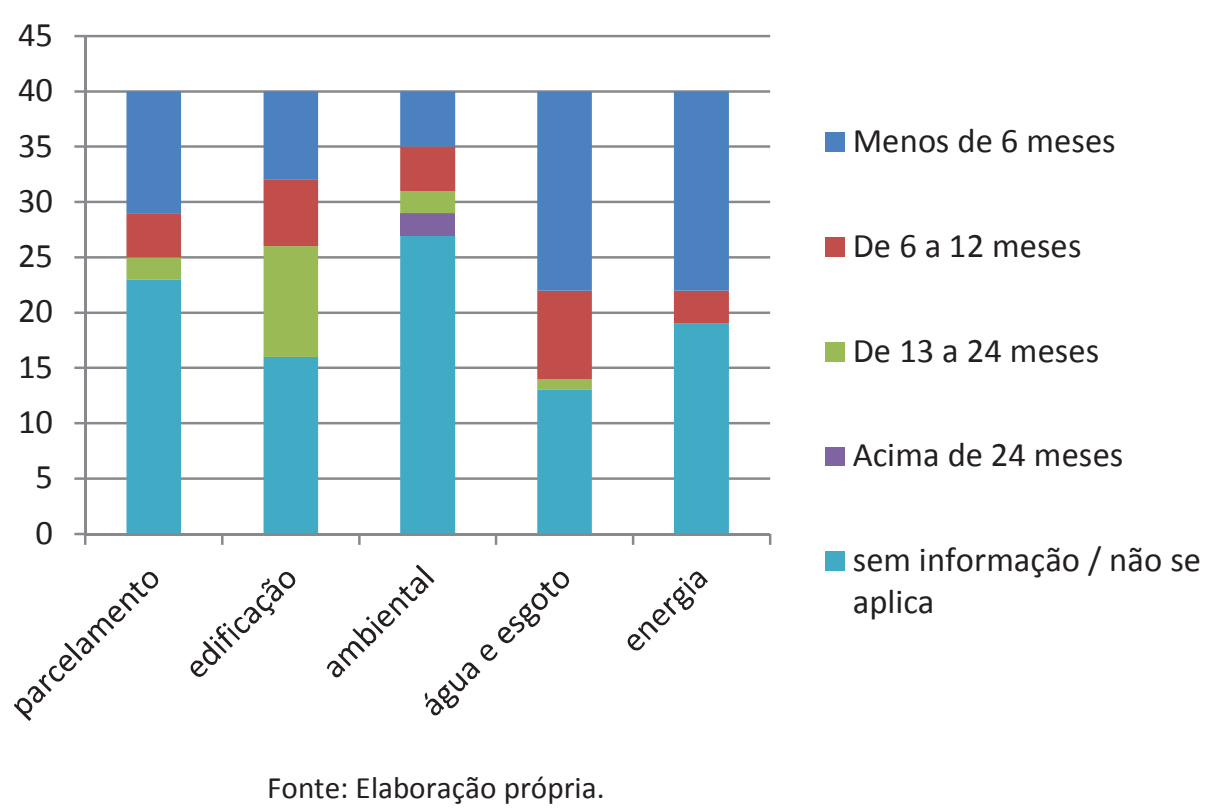

As empresas privadas que atuam no FAR têm feito as mesmas críticas aos procedimentos e à burocracia na aprovação interna na Caixa e nos órgãos de licenciamento, mas têm encontrado outras maneiras de enfrenta-la, como vimos no capítulo 4: alterações de normas e legislação; maior rapidez na "fila" de aprovações e excepcionalidades, garantidas muitas vezes por convergências de interesses; relações com ocupantes de cargos públicos; e até pagamento de propina ${ }^{130}$.

Aos movimentos fica a capacidade de pressão e mobilização como ferramentas utilizadas, ainda que parte deles, em situações pontuais, também usem os expedientes de relações com o poder. Cena que ilustra esse quadro é a mobilização realizada pela UMM, em São Paulo, em junho de 2011, no órgão responsável pela aprovação: Mais de 2 mil pessoas participaram para reivindicar "agilidade na aprovação dos Projetos de HIS e Terrenos vazios para o Programa Minha Casa Minha Vida Entidades" e foram recebidas com truculência pela Guarda Civil Metropolitana, "borrifando gás pimenta sobre os manifestantes, e ferindo outras pessoas, e ainda dando voz de prisão a uma companheira do Movimento ${ }^{131 ",}$ na, talvez, primeira repressão policial que se tem notícia a uma reivindicação desse caráter.

\footnotetext{
${ }^{130}$ Teve repercussão nacional a denúncia do Ministério Público contra Hussain Aref Saab, ex-diretor do Departamento de Aprovação de Edificações (Aprov) da Prefeitura de São Paulo. Disponível em: <http://g1.globo.com/sao-paulo/noticia/2012/05/advogado-diz-que-ex-servidor-de-sp-comprou-77-imoveisem-sete-anos.html>.

131 Mensagem eletrônica enviada pela UMM-SP, em 28/6/2011.
} 
Novamente, nota-se o papel e o significado da burocracia na manutenção dos privilégios e concentração de riqueza e oportunidades.

\subsubsection{Relação com os cartórios}

O Cartório de Registro de Imóveis (RI) é outro ator que passa a ter relevância no processo de viabilização de empreendimentos autogestionários no PCS e MCMV-E. Com o objetivo de transferir a propriedade plena e regular de cada unidade habitacional produzida ao final do contrato e de gravar a garantia bancária desde a contratação, todos os procedimentos da produção privada de habitação foram incorporados aos programas.

Os terrenos mais baratos onde os projetos habitacionais podem ser construídos têm, em algum momento, algum tipo de pendência jurídica: ou são glebas maiores que necessitam de aprovação de parcelamento; ou são áreas pendentes de retificação do perímetro, que devem tributos ao Estado, têm problemas na cadeia dominial ou na conclusão de inventários. Novamente, são os terrenos que sobraram no mercado imobiliário.

Para ser aceito no programa, pendências no Cartório de Registro de Imóveis, como retificações, finalização de inventários, dívidas e impostos incidentes, devem ser solucionadas antes da aquisição, ou retiram desses imóveis a possibilidade de ser adquiridos pelas entidades. Para viabilizar a aquisição desses terrenos, as entidades têm investido trabalho e recursos das famílias em áreas sobre as quais não têm garantia alguma de que vão adquiri-las.

No conjunto Vila de São Miguel, em Itaquaquecetuba/SP, as famílias arcaram com os custos de retificação e remembramento do imóvel ainda antes da compra, já que o proprietário afirmara que nada investiria para realizar a venda do terreno. Empresas privadas têm adquirido esses imóveis a preços mais baixos, com recursos próprios, solucionado as pendências e depois os colocando nos programas, a preços maiores. 
É preciso destacar que, muitas vezes, há dificuldades reais para a viabilização dos empreendimentos e má-fé dos vendedores, que passam a oferecer o que não podem entregar, com práticas ilegais de corretagem imobiliária. Como a maioria desses terrenos se encontra na periferia das cidades, lugares a princípio com regulação e base cadastral menos precisas, já foram verificadas matrículas e procurações falsas, assim como sobreposições de matrículas, poligonais que não coincidem com a realidade ou com conflitos não resolvidos com os proprietários confrontantes. As entidades passam a necessitar de apoio profissional para não investir em áreas que correm o risco de não servir para a aquisição pelo programa.

Além disso, soma-se a falta de experiência das entidades e assessorias técnicas em atuarem com os cartórios e seus procedimentos. Por se tratar de entidades do movimento popular, não havia relação anterior com os Rls, fazendo com que os prazos se alonguem e a desconfiança seja mútua. No empreendimento Vila Patrimonial, em São Paulo, o registro do contrato demorou mais de 100 dias, muito além dos 15 dias previstos pela legislação, impedindo o início do repasse dos recursos para a edificação.

Aos cartórios, não se pode exigir que deixem de aplicar a lei, mas, igualmente, não é razoável que, diante de questões novas postas pela legislação urbanística, também recusem o seu cumprimento. Nos empreendimentos do Grupo Esperança, no Rio de Janeiro/RJ e no Orlando Bacarin, em Apucarana/PR, houve dificuldades para registrar o contrato de financiamento em área cedida através de CDRU. O caso do Grupo Esperança foi ainda mais complexo, pois o cartório afirmava não poder lançar a garantia sobre uma CDRU coletiva, exigindo a individualização dos lotes previamente. Uma alternativa foi construída, com a definição de vários pequenos condomínios, mas, ainda assim, o início da obra atrasou em um ano, prejudicando as famílias, defasando o orçamento previsto e desconstruindo o arranjo social da CDRU coletiva.

Depois de resolvidas as questões sobre o domínio do imóvel, enfrenta-se a discussão sobre o parcelamento para a implantação do conjunto habitacional, que, após a aprovação nos órgãos licenciadores também deve ser registrado no RI, gerando novos procedimentos, prazos e custos. O PCS e o MCMV-E apenas excepcionalmente admitem a aquisição do terreno e a contratação sem o parcelamento aprovado. 
Outra dificuldade tem ocorrido, no caso de contratação de financiamento diretamente com os beneficiários finais, quando há necessidade de substituir a demanda. Como o lote, a fração ideal, ou até a gleba bruta, estão registrados em nome de cada uma das famílias participantes, no caso de substituição, é necessário transferir esse imóvel para o novo integrante do grupo, acarretando novos custos e prazos. Essa dificuldade foi vencida com a contratação dos financiamentos com a entidade organizadora, mas não na totalidade dos casos.

A lei do MCMV, na primeira etapa, determinou um desconto de $90 \%$ nos custos cartorários para os empreendimentos destinados à Faixa 1. Na segunda etapa do programa, esse desconto baixou para $75 \%$, devido à pressão dos registradores. Ainda assim, houve muita resistência, por parte dos cartórios, na aplicação do desconto, que foi inclusive contestado judicialmente, e, em algumas situações, somente foi aplicado após intervenção junto à corregedoria.

No caso de empreendimento em condomínio, também é exigida a incorporação imobiliária prévia à contratação. Esse item também foi alvo de divergências e exigiu mudanças no programa, como se verá no próximo item.

Apesar de ser obrigatório nos orçamentos dos programas, em alguns empreendimentos, os recursos destinados não foram suficientes para finalizar a legalização das unidades. Em Feira de Santana/BA, as famílias participantes do empreendimento Mangabeiras tiveram que tomar um empréstimo pessoal para arcar com parte dos custos cartorários.

Além disso, a multiplicidade de atores envolvidos para a regularização final dos empreendimentos - ligações das concessionárias de água, esgoto e energia, vistoria do corpo de bombeiros, companhia de gás, habite-se, regularidade no recolhimento de encargos à Previdência Social, que antecede o averbamento em cartório - faz com que esse processo se arraste para muito depois do término da obra. Como é necessário garantir a segurança das unidades concluídas e, na maioria dos casos, há pressão da própria demanda pela ocupação das unidades, diversos conjuntos foram ocupados por seus mutuários. Sem uma solução imediata para o problema, o poder público tolera a situação, mas mantém o empreendimento como "irregular" e "não concluído", em seus controles internos. 
A relação com o Rl é um cenário de constante enfrentamento, no qual, inclusive, a ação direta, por meio da ocupação da sede de um cartório na cidade de São Paulo, ocorrida em 2011, já foi utilizada como mecanismo de pressão para solucionar impasses. Dentre as propostas apresentadas pelos movimentos, algumas tentaram adaptar a exigência do MCMV-E às práticas dos movimentos:

\footnotetext{
- Individualização das matrículas (se for o caso) somente no final da obra, evitando gastos e burocracia desnecessários, bem como o desgaste das relações internas da obra;

- Garantir a gratuidade do registro para as etapas de contratação e entrega das moradias $^{132}$.
}

Mas a questão que rege essa diretriz tem relação com a possibilidade de inscrição de garantia real nos contratos do crédito imobiliário, de todas as faixas de renda do MCMV. Se, para os imóveis financiados pelo FGTS, essa garantia é fundamental, para os programas da Faixa 1, essa garantia é, no mínimo, inoperante. A medida foi questionada pela UNMP:
os processos autogestionários devem ser acompanhadas de medidas pró-ativas que impeçam a judicialização dos conflitos e a insegurança nos contratos. A alienação fiduciária para contratos de baixa renda é uma contradição, pois foi desenvolvida como medida de segurança dos contratos do Sistema Financeiro, enquanto o Minha Casa Minha Vida tem um caráter social ${ }^{133}$.

O embate com os cartórios tende a se ampliar, na medida em que os programas autogestionários vão se nacionalizando e novas questões surgem dos casos concretos.

\subsection{Compra antecipada}

As dificuldades encontradas pelas entidades para viabilizar terrenos e o aporte de recursos prévios para a elaboração e aprovação dos projetos no PCS, fez com que os movimentos elaborassem uma proposta que buscava reverter a lógica de contratação adotada pelo governo federal. Embora a questão já tivesse sido levantada em diversas negociações, foi somente nas reuniões que antecederam o lançamento do MCMV que o

132 UNMP, Propostas para o Minha Casa Minha Vida Entidades 2, 2011.
133 Idem. 
tema ganha um formato mais concreto, quando apresentada à então ministra da Casa Civil, Dilma Roussef.

A UNMP apresentou a proposta ao MCidades da seguinte maneira:

\begin{abstract}
Contratar em duas etapas: Na 1 a liberar recursos $(2 \%$ a $4 \%$ do valor do empreendimento + custo do terreno) para aquisição de terrenos, projetos, topografia e sondagem e capacitação do grupo pra autogestão na fase pré-obra mediante entrega da documentação para análise da viabilidade. Após elaboração dos projetos e aprovações, realiza-se a 2 a contratação para construção das casas. 0 terreno ficaria em nome da associação até a contratação do 2o contrato de financiamento das moradias. A garantia real para a Caixa seria o próprio terreno (UNMP, 2009).
\end{abstract}

A justificativa que mais sensibilizou o governo foi a constatação de que, diante de um mercado imobiliário aquecido, nenhuma entidade conseguiria obter um termo de opção de compra com prazo suficiente para elaborar e aprovar projetos, como citado anteriormente. Com a nova modalidade, esse prazo chegaria a cerca de 3 meses, mais aderente à realidade constatada pelos movimentos em suas negociações com as imobiliárias e os proprietários.

Apesar de ter sido aceita nas mesas de negociação, na formatação do MCMV, no início de 2009, a modalidade encontrou muita resistência interna no governo e só foi regulamentada 1 ano e 3 meses e algumas mobilizações depois ${ }^{134}$. A modalidade estava restrita a $20 \%$ dos recursos do programa ${ }^{135}$ e foi formalmente chamada de "Aquisição de terreno, elaboração de projetos e legalização", mas ficou conhecida pelos movimentos como Compra Antecipada. Para a contratação, a entidade deve apresentar um conjunto de documentos que dá a segurança jurídica para a aquisição do terreno ${ }^{136}$ e demonstrar a sua viabilidade técnica de utilização dentro dos parâmetros do programa, além dos documentos da própria entidade e das famílias que participarão do empreendimento.

A primeira área adquirida foi um terreno de $18.800 \mathrm{~m}^{2}$, na Cidade Tiradentes, em São Paulo, pelo Movimento Sem Terra Leste 1, filiado à UNMP e assessorado pela Ambiente Arquitetura, onde serão construídos os empreendimentos José Maria Amaral e Florestan Fernandes, com 198 apartamentos cada, em edifícios de até 11 andares. Tratava-se de uma

\footnotetext{
${ }^{134}$ Resolução 143, do CCFFDS.

${ }^{135}$ Atualmente, a modalidade tem como limite $30 \%$ dos recursos do programa. O MCidades alega que a necessidade de reservar recursos para as obras "esteriliza" os recursos do programa por um tempo muito longo.

${ }^{136} \mathrm{~A}$ área e seus proprietários devem estar desimpedidos de qualquer ônus.
} 
área privada, com origem em uma ação de usucapião, em frente a um conjunto da CDHU, implantado há mais de 15 anos. O processo de aquisição durou cerca de 15 meses, durante os quais os normativos do programa do MCidades e da Caixa foram sendo construídos simultaneamente à apresentação da proposta. Por fim, a entidade e a assessoria técnica apresentaram um projeto bem mais desenvolvido do que seria o necessário na proposta inicial da modalidade e com custos ainda elevados arcados pelo conjunto das famílias e por apoio externo ao projeto ${ }^{137}$.

Nesse momento da implementação da modalidade, a discussão que envolveu os movimentos, assessorias, a Caixa e o MCidades foi em torno do que seria o mínimo necessário para tornar-se um terreno apto para o programa. Sem as aprovações prévias, questionava-se o grau de imprevisibilidade com que a proposta se depararia. Os movimentos e assessorias se concentraram na construção de um conceito de "propostas aprováveis". Ou seja, após elaborar um estudo de massa para a implantação do empreendimento e um laudo ${ }^{138}$ onde, apesar de não ter passado pelos órgãos licenciadores, a proposta deve demonstrar que se enquadra na legislação incidente, como lei de uso e ocupação do solo, leis e normativos ambientais, e tem diretrizes de abastecimento de água e energia e de esgotamento sanitário. Em alguns municípios, existe a figura da certidão de viabilidade, que pode ser utilizada para essa finalidade, porém foram verificados poucos casos até o momento.

No entanto, o grau de subjetividade desse conceito levou a, muitas vezes, solicitações excessivas, desvirtuando o principal objetivo da Compra Antecipada, que é a agilização da operação. Temas como APPs, contaminação, necessidade de retificação cartorária, foram aparecendo como empecilhos à aquisição de áreas. O movimento argumentava que essas questões poderiam ser superadas após a compra e antes da contratação de obra. O que ocorreu foi que cada um dos empreendimentos contratados teve que ser tratado de forma específica. Nos últimos meses, tem se buscado um tratamento mais razoável da questão, após a realização de uma oficina com a Caixa e os movimentos, que será tratada adiante.

137 Além dos aportes mensais dos participantes, a proposta só se viabilizou com recursos oriundos de empréstimos da Igreja Católica e da ONG Hábitat para a Humanidade, além do trabalho da assessoria técnica Ambiente.

${ }^{138} \mathrm{O}$ roteiro proposto para a elaboração do laudo de viabilidade encontra-se no Anexo 4. 
Um exemplo dessa situação é o empreendimento Alexius Jafet, em São Paulo. Após a primeira vistoria, a área foi desqualificada pela equipe técnica da Caixa. O movimento reagiu e pediu a revisão do parecer apresentado, apelando para instâncias superiores no banco. Ao reapresentar a proposta e cotejá-la com a planta oficial da Empresa Paulista de Planejamento Metropolitano (Emplasa), verificou-se que continha um rio, que não mais existia no terreno. A proposta só foi aprovada quando a assessoria técnica apresentou um estudo onde deixava sem uso a faixa de APP do rio que não existia.

Comprado o terreno, conseguiu-se a descaracterização do rio e o projeto foi refeito com a nova diretriz. Ironicamente, após a compra e apresentação do projeto ao órgão ambiental, este levantou um problema diferente, a suposta existência de uma APP de Topo de Morro, que não havia sido detectado nem pela entidade, nem pela Caixa. Ou seja, as precauções que geraram atraso e retrabalho à associação não impediram que outras questões aparecessem.

A dificuldade em definir o que é considerado aprovável também se refere à questão do zoneamento, uso e ocupação do solo. No laudo de viabilidade, a entidade e sua assessoria técnica devem transcrever a legislação incidente, como as características do zoneamento, coeficiente de aproveitamento, gabarito, taxa de ocupação, dimensões mínimas permitidas, entre outros, e demonstrar que a proposta atende a esses requisitos. No entanto, enquanto os movimentos entendiam essa informação como suficiente, também surgiram divergências quanto ao papel da Caixa na interpretação da legislação local. Um dos casos, verificados, a proposta do empreendimento Santa Sofia, na Zona Sul de São Paulo, que se localiza em Área de Mananciais e é demarcada como Zeis, portanto, possui uma série de requisitos para a aprovação.

O Movimento de Habitação e Ação Social e a assessoria Ambiente apresentaram a proposta demonstrando terem seguido a legislação específica e a análise foi suspensa por se tratar de área de mananciais e, portanto, de alta complexidade para uma Compra Antecipada. Curiosamente, a mesma área havia sido citada como um exemplo positivo de Zeis na publicação do MCidades intitulada Como Delimitar e Regulamentar Zonas Especiais de Interesse Social. O impasse só foi superado e a análise retomada dois anos depois, após a pressão dos movimentos de moradia. 
Figura 50 - Área do empreendimento Santa Sofia

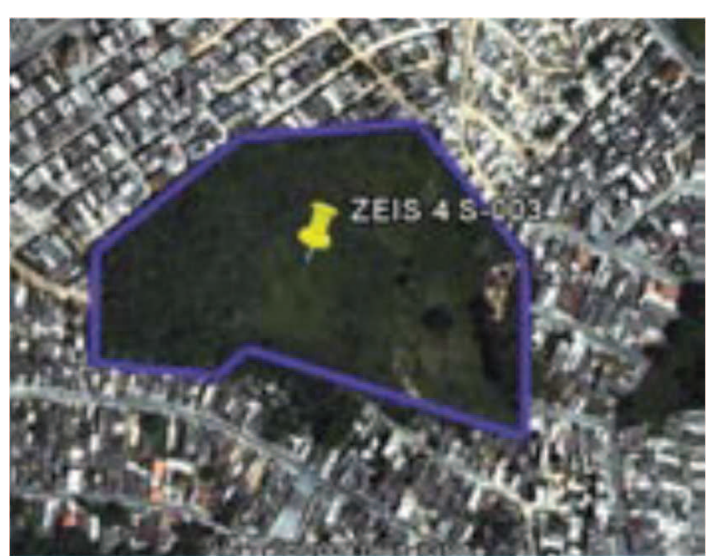

Fonte: Ministério das Cidades, Como Delimitar e Regulamentar Zonas Especiais de Interesse Social

Outro aspecto que limitou a Compra Antecipada foi a discussão sobre a suspeita de contaminação em áreas propostas pelos movimentos. Com a intenção de adquirir terrenos em áreas melhor localizadas, por exemplo, em regiões em processo de desindustrialização, o governo levantou a necessidade de laudos e pareceres sobre a possibilidade de contaminação dessas áreas e, nos casos positivos, sobre as alternativas de mitigação. Para conseguir esses laudos, as entidades necessitam de prazos mais longos e, principalmente, recursos, que não são disponibilizados pelo programa. Os órgãos ambientais têm pouca informação a respeito, restringindo-se apenas a informar sobre a possibilidade de contaminação.

A proposta do empreendimento Beneditinos, em Santo André/SP, é um dos casos exemplares que passou por essa situação. A entidade apresentou laudos que afirmavam existir a contaminação do lençol freático, por haver abrigado uma pocilga, o que impediria a utilização de água do subsolo. Apesar de a entidade apresentar um projeto com diretriz para a ligação na rede de água da concessionária e, portanto, não utilizar água do subsolo, foram exigidos novos laudos e a aprovação prévia do órgão ambiental. Foi necessário levar o problema à mesa de negociação em nível nacional para que a proposta fosse aceita, desde que houvesse uma cláusula em contrato de que a entidade se comprometia, novamente, em não utilizar a água do subsolo.

A questão que permeou todo esse debate, no entanto, se referiu ao risco da operação, ou seja, caso a proposta não fosse aprovada nos órgãos de licenciamento, como 
seria restituído o valor utilizado na compra do terreno. Por fim, estruturou-se uma operação de financiamento com a entidade, com carência de até 24 meses (12 meses prorrogáveis por mais 12). Caso a obra não fosse contratada, o financiamento entraria em retorno e a entidade teria que quitar a dívida em 12 meses. Embora esse dispositivo seja totalmente inócuo, dada a falta de capacidade financeira das entidades em saldar a dívida, esse formato aplacou a preocupação financeira e deu à modalidade um verniz de crédito hipotecário. Novamente, a lógica bancária se sobrepõe ao objetivo social do programa.

Ainda assim, a compra antecipada foi vista com desconfiança e pouco divulgada e utilizada. Na primeira etapa do MCMV-E, foram comprados apenas sete terrenos nessa modalidade, todos na Região Metropolitana de São Paulo, destinados à construção de 1.952 unidades, com um esforço empreendido muito maior do que os resultados conquistados. Nesse sentido, quando discutida a segunda etapa do MCMV, a UNMP apresentou ao MCidades algumas propostas para ampliar sua atuação e dirimir algumas dificuldades encontradas:

\footnotetext{
- Ampliar e aperfeiçoar a modalidade Compra Antecipada como instrumento de combate à especulação imobiliária, garantindo a desburocratização dos procedimentos;

- Aumentar o percentual de recursos para a modalidade da Compra antecipada;

- Simplificar e difundir os critérios da Modalidade, possibilitando a aquisição de terrenos com projetos "aprováveis", justificado com o cumprimento da legislação incidente;

- Aceitar terrenos com pequenas retificações a serem feitas, desde que essas não interfiram no número de unidades e qualidade do empreendimento (UNMP, 2011).
}

Uma das razões para a modalidade não ter tido maior abrangência no País foi a resistência e o desconhecimento dentro da própria Caixa. Apesar de os movimentos terem divulgado a Compra Antecipada para sua base, em nível nacional, há relatos de grupos que ao solicitar informações para apresentar terrenos para a aquisição. foram informados de que a "modalidade não existia" no $\mathrm{MCMV}^{139}$. Somente após a intervenção do movimento e de áreas da Matriz da Caixa é que a questão foi esclarecida.

\footnotetext{
${ }^{139}$ Essa situação foi relatada por coordenadores do movimento de moradia em Fortaleza/CE, Aracaju/SE e Manaus/AM, entre outros.
} 
Já na vigência do MCMV 2, o tema foi retomado pelos movimentos, que realizaram algumas manifestações, como a Caravana à Brasília, do FNRU, em outubro de 2011, ocasião em que reivindicaram:

uma urgente política de distribuição de terras para que se possa alavancar com mais agilidade a produção habitacional nos centros e nas periferias, e para democratizar o acesso às terras do governo federal. Para enfrentar a especulação imobiliária, que tira a possibilidade de produção habitacional para as famílias de renda, é fundamental a ampliação dos recursos para compra antecipada de terrenos (FNRU, 2011).

Figura 51 - Caravana à Brasília- 2011 - FNRU

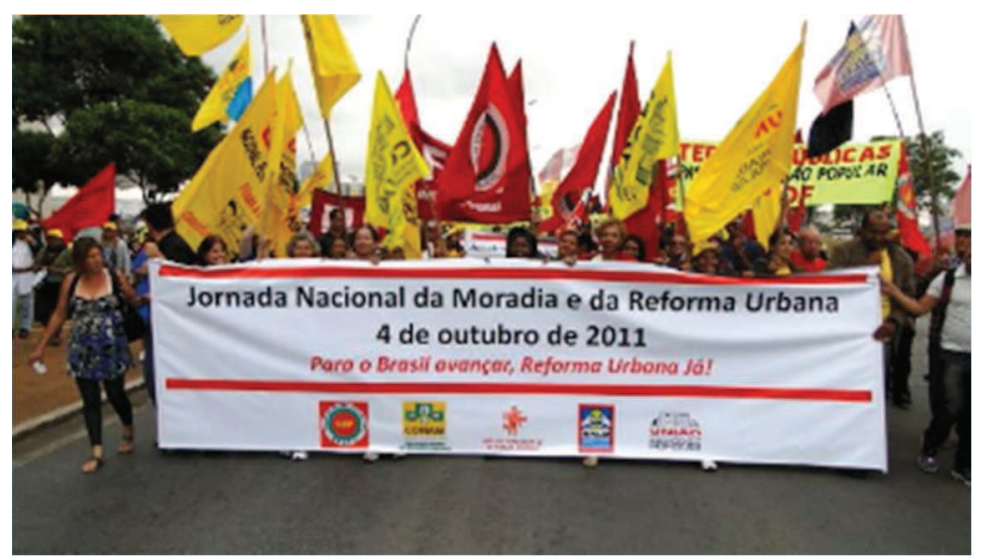

Fonte: Acervo FNRU

Em nova jornada, as dificuldades encontradas no programa são destacadas, inclusive com uma ocupação da Matriz da Caixa em Brasília, em abril de 2012, exigindo a agilização do programa:

Reafirmamos que a compra antecipada de imóveis para moradia popular foi uma conquista dos movimentos, e é um avanço para o Programa MCMV, no entanto, as dificuldades colocadas são tantas, que a viabilização dos terrenos - que já são difíceis de serem encontrados - muitas vezes, pela demora, acabam não se efetivando, dificultando ainda mais, a vida das Associações e das famílias que esperam por anos a sua moradia (UMM-SP, 2012).

Nesse momento, as primeiras áreas que haviam sido adquiridas em 2010 entram na fase de contratação de obra e novas dificuldades aparecem. Como se tratava de operação de financiamento para a entidade adquirir o terreno, na contratação da obra com os beneficiários seria feita uma operação contábil em que a entidade venderia frações desse terreno aos participantes, que quitaria a operação inicial. No entanto, para que o novo 
financiamento pudesse ser concedido e formalizado em Cartório de RI, a entidade deveria realizar "incorporação imobiliária".

Os movimentos entenderam que tal exigência desvirtuaria completamente os seus princípios, pois não thes cabe vender áreas aos próprios associados. Além disso, a incorporação imobiliária é uma figura da produção privada que não se aplica à produção comunitária, em que a associação é uma representação do coletivo e não um terceiro, alheio ao grupo. Também foram encontrados empecilhos nos cartórios, no registro da incorporação. Os movimentos não aceitaram a exigência e, em conjunto com o governo, desenharam uma alteração, reivindicada na mobilização citada anteriormente:

Fim da exigência da incorporação imobiliária prévia;

Regulamentação da modalidade da contratação da entidade como substituta dos futuros moradores até a conclusão da obra, com garantia de enquadramento da demanda ${ }^{140}$.

O impasse só foi superado com a Resolução 190/2012, quatro meses depois. A medida também permitiu que os empreendimentos pudessem ser contratados diretamente com a entidade, individualizando-os apenas ao término da obra de construção. A UNMP manifestou que essas modalidades "reconhecem o protagonismo das entidades populares e fortalecem a autogestão" (UNMP, 2012).

Em maio de 2012, a Caixa realizou um Seminário Nacional sobre o programa, que contou com participantes de movimentos e das Gidur de todo o País, de assessorias técnicas, das áreas da Matriz da Caixa envolvidas com o programa, do MCidades e da SPU. Esse seminário teve como objetivo discutir as alterações necessárias ao funcionamento do programa e divulgar a modalidade Compra Antecipada.

No seminário foram aprovadas 138 propostas, sobre os mais diferentes aspectos do programa, o que levou à mudança de algumas regras e também à realização de seminários em todos os estados para a difusão da modalidade. Dentre as regras de operação modificadas, está a simplificação de documentos para a modalidade, o estabelecimento de prazos para as análises e a divulgação de material com os requisitos do programa. Além

\footnotetext{
140 Ofício da UMM-SP ao Governo Federal, abril de 2012.
} 
disso, novas resoluções ${ }^{141}$, além de criar as modalidades citadas, deram melhor definição para os itens financiáveis do programa, retiraram o teto do valor de avaliação das unidades produzidas $^{142}$ e regularam a análise do enquadramento das famílias participantes, no caso de contratação direta com a entidade. Essas mudanças começaram a ser aplicadas recentemente e ainda não é possível verificar os seus efeitos.

Apesar da lenta implementação e das resistências encontradas, a Compra Antecipada passou a ser vista pelos movimentos como uma ferramenta importante que, ao mesmo tempo, reconhece as dificuldades das entidades no mercado imobiliário, colocando alguma vantagem em suas mãos. Até o final de 2012, o MCMV 1 e o 2 haviam contratado, nessa modalidade, a aquisição de 16 áreas para 32 empreendimentos ${ }^{143}$ com 7.300 unidades, representando $40 \%$ das contratações do programa. Além de São Paulo, a modalidade também foi implementada em Goiás, Pernambuco, Amazonas, Minas Gerais e Rio Grande do Sul.

Tabela 8 - Contratos de aquisição de terreno e

\begin{tabular}{|c|c|c|}
\hline UF & Empreendimentos & UHs \\
\hline $\mathrm{GO}$ & 3 & 900 \\
\hline PE & 1 & 500 \\
\hline AM & 3 & 600 \\
\hline MG & 1 & 192 \\
\hline RS & 6 & 932 \\
\hline SP & 18 & 4.176 \\
\hline Total & 32 & 7.300 \\
\hline
\end{tabular}

Fonte: Elaboração própria.

Existem, dentro da Caixa para análise e contratação, propostas em pelo menos 15 cidades e espera-se que, com a realização dos seminários locais entre os movimentos e a Caixa, mais propostas sejam apresentadas. A modalidade, no entanto, está limitada, por resolução do CCFDS, como já foi dito, a 30\% dos recursos disponíveis para o programa.

\footnotetext{
${ }^{141}$ Resoluções do CCFDS 190, 193 e 194, de 2012.

142 O programa tinha um limite de valor de avaliação muito próximo ao de financiamento. No entanto, com os aportes conquistados junto aos governos locais e às ações de autogestão, os imóveis a serem produzidos apresentavam avaliação de mercado muito superiores, exigindo a sua flexibilização. $O$ apartamento que será construído no empreendimento Florestan Fernandes, com R\$ 96 mil, teve avaliação de mercado acima de $R \$$ 130 mil.

${ }^{143}$ A modalidade permite a aquisição de um terreno para ser desdobrado em até três empreendimentos.
} 


\subsection{Terras públicas federais}

A utilização de áreas ociosas da União e de empresas e autarquias federais é pauta constante na agenda de lutas dos movimentos sociais, no sentido de exigir que o governo federal também cumpra os preceitos da função social da propriedade previstos na Constituição Federal e no Estatuto da Cidade. A constatação de que existem muitos imóveis ociosos localizados em áreas centrais de diversas cidades fazem com que estes sejam considerados estratégicos em uma política de viabilizar habitação popular no centro. Inicialmente, os próprios movimentos e depois o MCidades e a Secretaria do Patrimônio da União identificaram um conjunto de imóveis considerável que teria interesse e vocação habitacional. Entretanto, em dez anos, poucos imóveis foram efetivamente destinados e convertidos em habitação.

A estratégia de ocupar imóveis federais foi adotada pelos movimentos participantes do FNRU durante os últimos 15 anos. A ocupação do edifício do INSS da Avenida 9 de Julho, em São Paulo, em 1997, é emblemática, tanto pela visibilidade que teve à época, repercutindo a questão dos imóveis vazios e vinculando o tema à falta de moradia, quanto pela constatação do nível de dificuldade para a sua destinação e viabilização de moradias: após cinco ocupações, dois incêndios, três Presidentes da República, projetos aprovados e após ter transitado por todos os programas habitacionais criados no período, até o momento, o edifício continua vazio e em processo de franca deterioração.

Figura 52 - Edifício do INSS da Avenida 9 de Julho - 2001

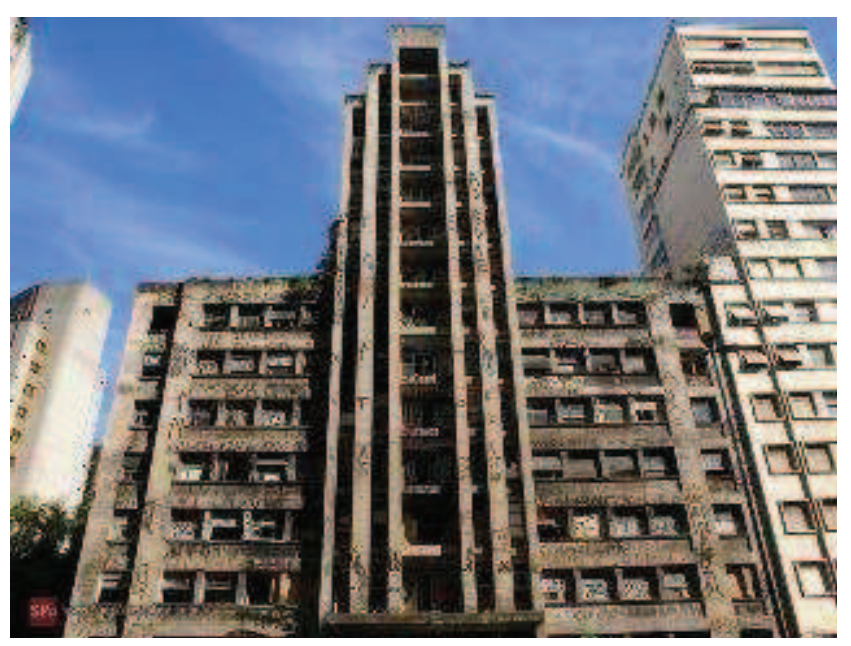

Fonte: <www.saopauloantiga.com.br>. Acesso em: 12 jan. 2012 
A partir de 2003, o governo afirma a intenção de destinar os imóveis vazios federais para habitação. Em diversas situações públicas, o Presidente Lula manifesta essa intenção, inclusive cobrando dos órgãos responsáveis a sua efetivação. No entanto, essa proposta demonstra ser muito mais difícil de ser viabilizada do que se cogitava à época. A máquina estatal estava montada e amparada em uma série de dispositivos legais e infra-legais que, na prática, inviabilizavam a destinação de imóveis para finalidades sociais, mas privilegiavam o setor econômico. Os mecanismos de aforamento e leilões obrigatórios para a destinação de imóveis deixaram sempre de lado justamente os mais pobres, sem acesso aos imóveis ou a financiamento para obtê-los.

Além disso, diversos procedimentos permeados por interesses privados e expedientes de corrupção interpunham-se em diversos órgãos e faziam, por exemplo, com que o governo sequer tivesse um inventário completo de seus imóveis. Uma série de esforços foram empreendidos desde então pelo MCidades, SPU e Ministério da Previdência Social, com a identificação de imóveis e inclusive mudança de legislação para os imóveis da SPU e do INSS ${ }^{144}$ e com o patrimônio da extinta Rede Ferroviária Federal (RFFSA) sendo incorporado ao patrimônio da União.

Uma das dificuldades encontradas foi a falta de uma base cadastral sólida e consolidada sobre os imóveis ociosos do governo federal. Esse processo, iniciado pela Secretaria Nacional de Programas Urbanos busca consolidar listas de imóveis, e realiza vistorias em conjunto com movimentos sociais, identificando imóveis adequados para a finalidade habitacional, mas com resultados aquém do esperado na efetiva destinação.

Isso gera inúmeras manifestações e ocupações em imóveis federais: de 2003 a 2012, foram identificadas cerca de 15 mobilizações organizadas em diversos estados brasileiros, com a ocupação de cerca de 40 imóveis da SPU, INSS e RFFSA. Em todos os documentos dos movimentos, as expressões "agilização" e "desburocratização" na destinação de terras públicas figuram, tendo sido protagonista dos momentos de impasse entre os movimentos e o governo, nesse período.

Outro tema importante é a questão da terra para moradia e a situação dos imóveis da União. Exigimos uma urgente política de distribuição de terras para que se possa

\footnotetext{
${ }^{144}$ Lei 11.481, de 31 de maio de 2007.
} 
alavancar com mais agilidade a produção habitacional nos centros e nas periferias, e para democratizar o acesso às terras do governo federal (UMM, 2011).

Figura 53 - Ocupação em imóvel do INSS - São Paulo-SP - 2010

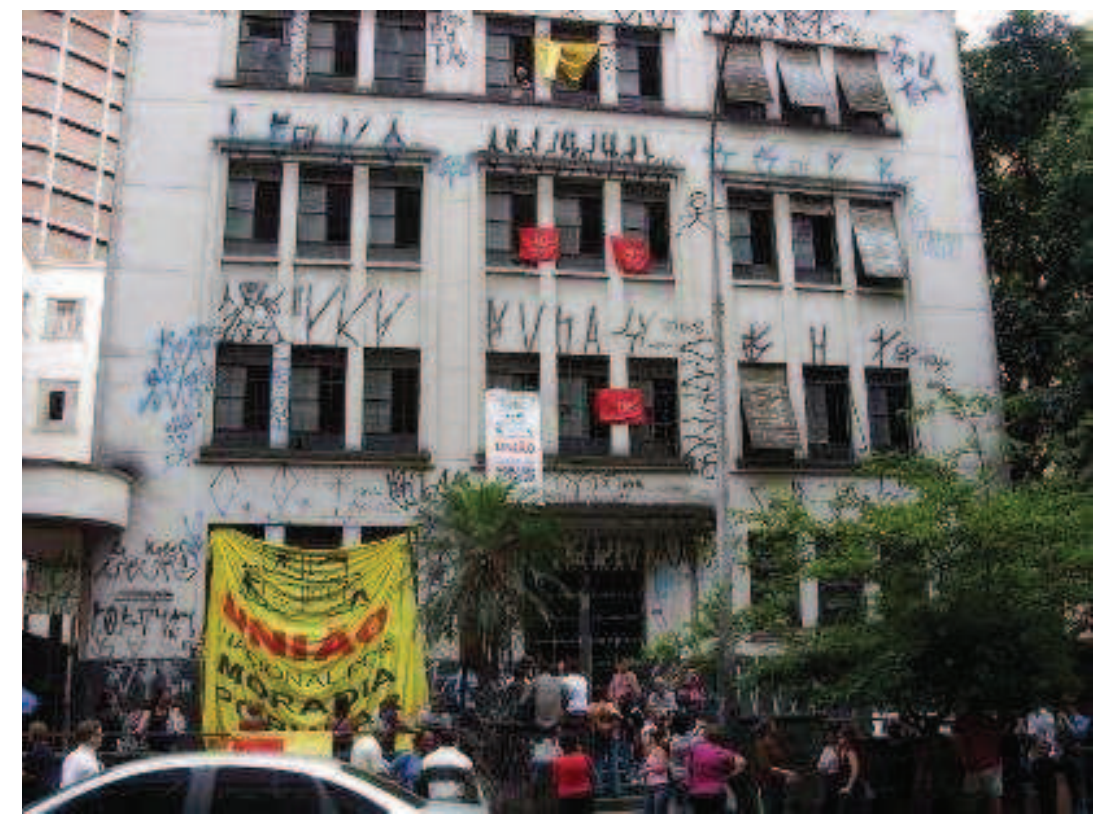

Fonte: Acervo UMM-SP

A SPU criou, em 2008, o Grupo de Trabalho (GT) Nacional para Programas de Provisão Habitacional de Interesse Social, integrado por membros do Conselho Nacional das Cidades e com a finalidade de "destinação de imóveis da União para programas de provisão habitacional de interesse social e fortalecimento da gestão democrática desse patrimônio"145. O grupo discutiu a compatibilização dos normativos e exigências dos programas de habitação com a legislação e procedimentos para destinação da SPU, além de criar os critérios de seleção pública para os imóveis da União.

Com o protagonismo dos movimentos sociais dentro desse GT e as atividades de pressão, o grupo definiu e priorizou a destinação de imóveis para os programas das entidades sociais. Como ação complementar ao GT Nacional, foram criados Grupos de Trabalho Estaduais (GTEs), com composição semelhante à instância nacional, e com a atribuição de identificar os imóveis desembaraçados passíveis de destinação e acompanhar os editais de seleção de entidades para a atribuição de cada imóvel.

\footnotetext{
145 Portaria 80, de 26 de março de 2008, da Secretaria do Patrimônio da União.
} 
Os GTEs tiveram funcionamento irregular. Em alguns Estados, houve maior envolvimento das Superintendências Regionais do Patrimônio da União e das próprias entidades da sociedade civil, viabilizando alguns imóveis para HIS. No entanto, avaliação recente dos movimentos, cobra maior efetividade dessas ações e denuncia que os objetivos não têm sido alcançados.

(Esses problemas) têm resultado numa série de problemas que dificultam a cessão das áreas para os movimentos populares, privilegiam o poder público, não disponibilizam os cadastros fundiários de forma transparente, criam GTEs fictícios e dificultam a realização das tarefas deliberadas pelo GTN (UNMP, 2012).

Além desses problemas, o governo deparou-se com a fragilidade de sua base fundiária e a falta de regularidade de registro de suas áreas: o cadastro da SPU (Sistema Integrado de Administração Patrimonial - Siapa) apresenta lacunas, há várias matrículas antigas e imprecisas nos cartórios e não existe um tratamento padronizado para a sua regularização, o que tem dificultado e, em alguns casos, até impedido a destinação para HIS. A SPU deparou-se também com conflitos locais, envolvendo prefeituras e outros interesses econômicos, que pressionam para que a área não seja destinada para moradia popular, chegando a inviabilizar propostas apresentadas por entidades. Esse conjunto de dificuldades fez com que o resultado fosse avaliado pelos membros do GT como insuficiente. Em quatro anos de atuação do GT,

24 (vinte e quatro) processos de destinação foram concluídos e tiveram os contratos assinados, sendo ao todo destinados 4.582.565,00 $\mathrm{m}^{2}$ a associações sem fins lucrativos e cooperativas (e) 7.754 famílias serão diretamente beneficiadas (...) e 28 (vinte e oito) imóveis, com cerca de 626.131,00 $\mathrm{m}^{2}$, foram reservados para as entidades sem fins lucrativos e cooperativas (desenvolverem projetos e apresentarem ao MCMV) (SPU, 2012).

Outra área de enfrentamento envolve as terras da extinta RFFSA. A Lei 11.483, de 31 de maio de 2007, extinguiu a RFFSA e destinou seus imóveis não operacionais remanescentes para o Patrimônio da União. No entanto, também determinou a constituição de um Fundo Contingente para o pagamento das dívidas, especialmente trabalhistas da empresa, integrado, dentre outros, pelo produto da venda dos imóveis não operacionais. Isso gerou um impasse, devido a uma interpretação de que os imóveis somente poderiam ser incorporados à SPU, e, por consequência, destinados quando o Fundo de Contingência estivesse integralizado, paralisando todo o processo de incorporação. 
Somente em 2011, foi estabelecido que deveria ser feita uma reserva de imóveis para o Fundo, que liberaria a carteira restante. No entanto, aconteceram diversas denúncias de que imóveis não foram nem destinados ao Fundo, nem à SPU, mas destinados sem qualquer transparência ou controle. Além disso, a falta de um cadastro preciso, as dificuldades encontradas nos cartórios na incorporação e no desmembramento dessas áreas, que por vezes abrangem até três estados da Federação e ações judiciais sobre esses imóveis impediram, mais uma vez, a efetiva destinação de um número significativo de imóveis para HIS.

Além disso, outra frente de discussão relaciona-se aos imóveis de propriedade do INSS. Em geral, são antigas dependências do Instituto ou imóveis recebidos em pagamento de dívidas de empresas para com o Fundo Previdenciário. Desse modo, integram o patrimônio desse fundo e não podem ser destinados sem restituição de seu valor, devendo ser vendidos em leilão ou a outros órgãos públicos. Por se tratar, muitas vezes, de imóveis bem localizados, mas bastante deteriorados, não conseguem ser vendidos em leilão e permanecem desocupados por vários anos, resultando em um problema para as cidades. Os movimentos empreenderam diversas lutas para viabilizar a destinação desses imóveis para HIS.

Mesmo com a alteração legal feita em $2007^{146}$, que revisou as condições de venda dos imóveis do INSS e permite que os imóveis sejam alienados pelo valor de viabilidade econômica do programa habitacional, o impasse continuou. Foi aprovada, para uma lista de imóveis historicamente reivindicados pelo movimento, uma excepcionalidade que permitia a aquisição desses imóveis pelo "valor de viabilidade" para programas habitacionais, mas, até o momento, apenas um edifício no centro de Porto Alegre/RS, ocupado pelo MNLM por ocasião do 4응́rum Social Mundial, em 2004, efetivamente foi destinado para HIS por meio do programa Crédito Solidário.

\footnotetext{
${ }^{146}$ Lei 11.481, de 31 de maio de 2007.
} 
Figura 54 e 55 - Edifício Residencial Conquista - PCS - 48 UH - Coopernova - MNLM - Porto Alegre/RS - 2010
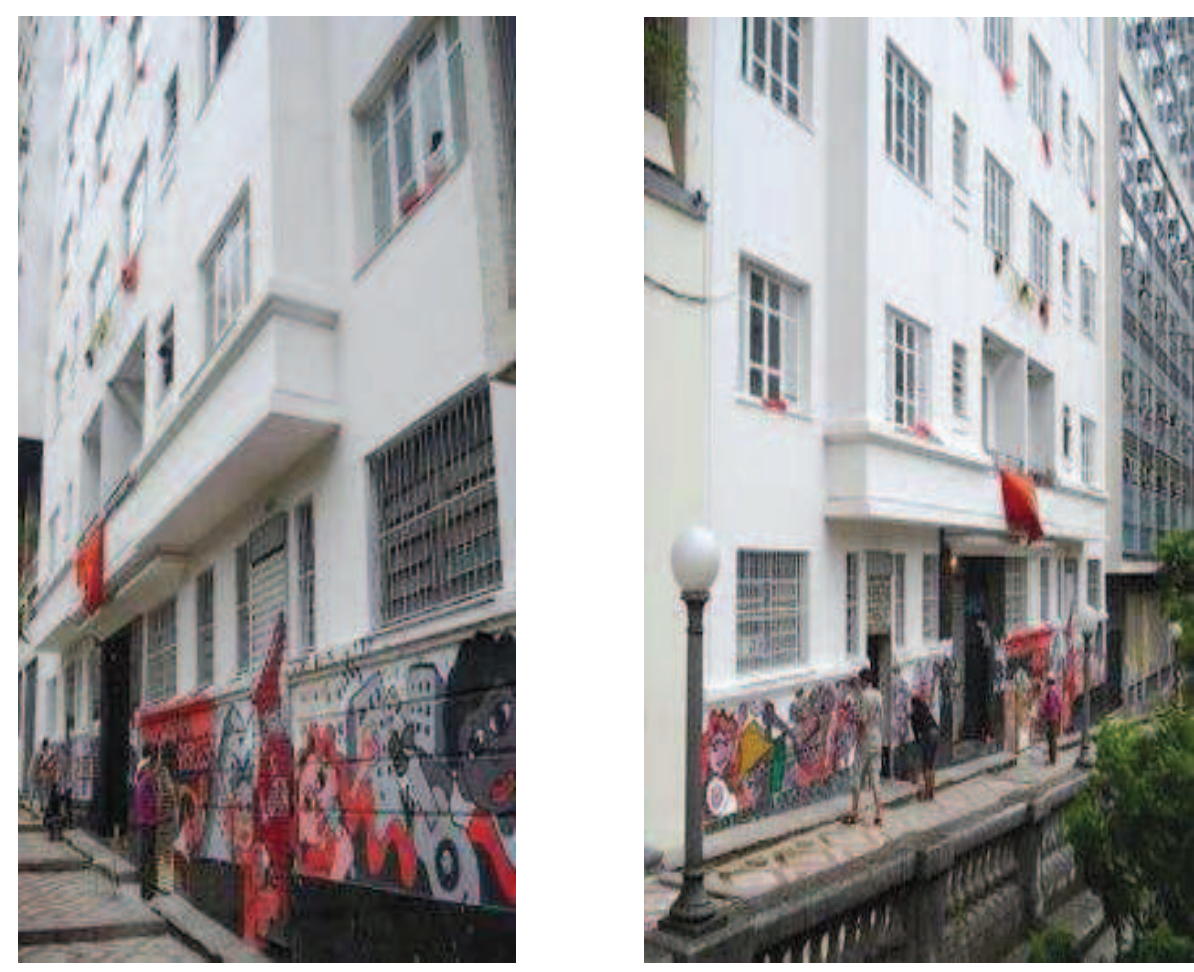

Fonte: Coopernova

Em 2009, por meio do MCidades, com uma rubrica específica do OGU, o governo comprou 23 imóveis do INSS para repassá-los ao FAR, por meio da seleção de construtoras para desenvolver projeto e obra e de entidades para a indicação de demanda. Devido a uma série de dificuldades encontradas na viabilização, até o momento, apenas dois conjuntos foram entregues nessas áreas. Essa estratégia, no entanto, não teve seguimento nos anos seguintes, apesar da reivindicação dos movimentos.

Por fim, no início de 2012, a Presidência da República solicitou à SPU prioridade na destinação de terrenos para o MCMV, porém, justificando a necessidade de agilidade na produção das moradias, esses imóveis não passariam pelos GTEs ou GTN e seriam destinados ao FAR para serem utilizados por empresas construtoras. Isso provocou novas ações do movimento de moradia, como a manifestação realizada nos dias 2 e 3 de setembro, denominada Em Defesa do Acesso às Terras Públicas para Moradia Popular! Dentre as reivindicações, destacavam-se:

Transparência na discussão e destinação de imóveis do governo federal, dando prioridade ao interesse social; Retomada da destinação de imóveis não operacionais da extinta RFFSA para habitação social com apoio técnico para a regularização dos imóveis; Desburocratização da destinação e apoio para a 
elaboração de projetos em imóveis do governo federal; Nenhum terreno público para as construtoras. Que as construtoras não sejam priorizadas nem no tratamento, nem no limite de valores do Programa Minha Casa Minha Vida em detrimento das entidades, exigimos equiparação entre os valores do FDS e FAR (CMP e UNMP, 2012).

Essa dificuldade na destinação dos imóveis para HIS e no combate à ociosidade dos imóveis públicos leva a uma reflexão sobre o cumprimento da função social desses imóveis. Inclusive por terem, muitas vezes, localização estratégica, nos centros das cidades, no entorno de antigas estações ferroviárias, além de abrigarem famílias de baixa renda, sem moradia, poderiam cumprir um papel indutor na reabilitação de áreas centrais. Esses imóveis têm sido alvo do interesse especulativo privado e historicamente destinados ao uso das elites, como clubes e condomínios a beira-mar. Romper com essa lógica e destiná-los ao uso coletivo e à moradia dos mais pobres significa romper com uma estrutura montada para outra finalidade.

Além disso, esses imóveis são isentos de qualquer imposto e estão imunes à maioria dos instrumentos urbanísticos, seja por disposição legal ou por opção política dos gestores. Nesse sentido, quando vazios, deseducam a cidade, ao não cumprir o disposto constitucional e o Estatuto da Cidade. 


\section{Conclusões}

A proposta autogestionária de produção habitacional no Brasil nasce junto com o processo de redemocratização, com o fim da ditadura militar incorporando os princípios de construção de poder popular, descentralização do poder e disseminação da economia solidária, por meio de um processo de produção não mercantil que valoriza a moradia como direito e a cidade como território de realização de direitos.

A política habitacional brasileira tem, historicamente caminhado no sentido oposto ao priorizar a produção privada em todos os seus aspectos, inclusive aquelas financiadas ou subsidiadas com recursos públicos. Hoje o Programa Minha Casa Minha Vida convoca o mercado, para que esse ofereça propostas a serem financiadas pelo poder público, se eximindo de seu papel de planejar, projetar e implementar as políticas habitacionais.

O Programa Minha Casa Minha Vida inovou também ao estabelecer uma meta quantitativa relevante e destinar recursos subsidiados e onerosos para a produção de 3,4 milhões de unidades habitacionais em seis anos. No entanto, adota o modelo de produção privada praticamente como modelo único e a propriedade individualizada do imóvel como garantia real de financiamento, mesmos nos casos de financiamento altamente subsidiado.

Nesse contexto, o programa Minha Casa Minha Vida Entidades não se diferencia, em sua essência, da sua versão dirigida às construtoras. Com regras e procedimentos bastante semelhantes, o programa busca enquadrar entidades e cooperativas na lógica da produção privada.

As moradias produzidas em processos autogestionários tem, de modo geral, melhor qualidade de projeto e de construção e certamente os processos sociais dos grupos que se organizam para produzir coletivamente são muito distintos dos conjuntos produzidos tradicionalmente e das demandas indicadas para habita-los sem um processo anterior de organização. 
Algumas organizações de luta por moradia fazem um movimento de resistência, buscando adaptar o programa aos princípios da proposta autogestionária, alterando as regras e procedimentos, sem no entanto, conseguir mudar a concepção do programa. Hoje, as entidades são enquadradas como "produtores privados", ignorando-se a relação intrínseca entre as entidades e seus associados, que são tradados como clientes de um negócio e não como agentes da ação coletiva. Esses impasses tem desafiado o movimento a discutir o marco legal que incide sobre a relação entre estado e entidades sociais, especialmente na implementação de políticas, com uma melhor definição de seu papel na produção habitacional, como agentes públicos não estatais.

Verifica-se também o pouco apoio dado às propostas autogestionárias e à organização e capacitação de entidades para a viabilização de propostas. Sem política para o tema, cabe às próprias entidades buscarem em recursos captados entre os seus associados ou nas poucas entidades de cooperação para a sua estruturação e qualificação de quadros para a gestão de empreendimentos habitacionais e a ação formativa junto aos participantes. Na sua ausência, permanece um caráter voluntarista e com dificuldade da ampliação da escala de atuação, além de restringir a participação de pequenos grupos que não contam com estrutura própria e/ou apoio externo, ou ainda abrindo caminho para práticas oportunistas e empresariais que destoam da proposta autogestionária.

A mesma situação ocorre com o tema das assessorias técnicas, que encontram dificuldades para estruturar-se e/ou dedicar-se exclusivamente à produção autogestionária, bem como reter quadros técnicos na disputa com o mercado. Como os financiamentos públicos são focados em cada um dos empreendimentos isoladamente, eles não atendem à necessidade dos movimentos em contar com assessoria permanente para trabalhar processos de organização e formulação de propostas para aperfeiçoamento das políticas e programas, busca de áreas e elaboração participativa dos projetos.

Esse quadro se é mais agudo se analisarmos a relação dos movimentos de moradia na viabilização de terrenos para a produção habitacional de interesse social. A questão do acesso à terra está presente desde a organização dos movimentos de moradia desde a década de 1980. Muitos dessas entidades iniciaram sua organização através de ocupações de terra e do questionamento, de forma direta, do não cumprimento da função social da 
propriedade. As ocupações de terras e edifícios vazios questionam o próprio conceito de propriedade.

De modo geral, as políticas habitacionais têm tratado a questão da terra como acessória estando focadas apenas no financiamento e estabelecidas a partir do objetivo de dinamização econômica, a partir da capacidade de geração de empregos na cadeia do setor da construção civil. O resultado é bastante conhecido: a maior parte da produção se dá através dos conjuntos habitacionais construídos nas periferias das cidades, com baixa qualidade urbanística e arquitetônica e com vínculo precário à malha urbana.

Relevante ainda para os objetivos deste trabalho é a necessidade de se reconhecer hegemonia do modelo liberal de aquisição da propriedade. O processo de privatização da terra está presente desde o Brasil Colônia e atingiu sua forma definitiva com sua clara identificação como mercadoria com a Lei de Terras de 1850. A evolução de sua implementação acarreta o impasse mais substantivo no que diz respeito a realização dos objetivos fundamentais das políticas urbanas em geral, e da garantia de acesso à terra urbanizada para todos preconizada no Estatuto das Cidades, em particular. Esse quadro se agrava com a recente financeirização do mercado imobiliário, que coloca a terra urbana em lugar de destaque na constituição de ativos das empresas.

O Programa Minha Casa Minha Vida não oferece alternativa a esse modelo, pelo contrário, ao disponibilizar recursos consideráveis para a produção habitacional e sem definir, em conjunto com municípios, uma estratégia fundiária, colabora para a o incremento dos preços da terra e a exclusão dos mais pobres para os piores lugares, ratificando o ciclo de exclusão territorial característico de nossas cidades.

Aos movimentos por reforma urbana, em especial aos movimentos por moradia, restou compreender que a luta pelo solo urbano deslocou-se do campo formalmente institucional para a arena dos negócios internacionais, aumentando o nível de complexidade envolvido na questão. Além da atuação através das estratégias tradicionalmente hegemônicas na cultura atual da política urbana, para qual a solução dos conflitos fundiários se daria em arenas públicas dedicadas à regulação das por meio de processos participativos e garantidores de certa distributividade das políticas públicas, os movimentos lançaram-se 
também na disputa direta pelo território, sem, entretanto dispor das condições objetivas para tanto. Os resultados demonstram a precariedade dessa estratégia e seus limites.

A ação dos movimentos de moradia na busca de terras para os programas habitacionais tem consumido as energias desses atores sem conseguir alterar a lógica da produção habitacional periférica para os segmentos de mais baixa renda. Apesar de ter acesso a mecanismos de financiamento para a aquisição de terrenos no mercado, sob um cenário em que as forças de cada agente são extremamente desiguais, restam para as entidades as áreas que sobram no mercado. Ainda assim, os diversos expedientes necessários para que essas áreas sejam aproveitáveis no programa, como licenciamentos e regularização registrária, dificultam ainda mais esse caminho. Esses requisitos são exigidos pelos programas habitacionais para que essas áreas se tornem executáveis pelos agentes financeiros, utilizando-se do instrumento da alienação fiduciária para rapidamente retomar o imóvel em caso de inadimplência. Trata-se de mecanismos de mercado regulando um programa social, demonstrando sua total incoerência.

A inserção dos movimentos na lógica da disputa do mercado fundiário é, no mínimo, limitada, além de deslocar aquilo que deveria ser uma política pública abrangente sobre o território para ações pontuais e desconexas.

Por outro lado, a utilização de terras públicas, que poderia ser um contraponto a esse modelo fornecendo uma ação exemplar na utilização de vazios urbanos para moradia popular, não tem ocorrido na velocidade e quantidade necessárias. Mais uma vez percebe-se que o aparato burocrático e legal - inclusive aquele que rege a terra pública - não está montado para atender aos interesses coletivos e ao direto à moradia, especialmente dos mais pobres.

Nesse contexto, as promessas contidas no Estatuto da Cidade na democratização do acesso à terra e no cumprimento da função social da propriedade parecem não conseguir fazer frente à voracidade do mercado imobiliário na era da financeirização. Uma serie de instrumentos de planejamento urbano, captura de mais-valia fundiária e de controle social, apesar de inscritos em grande parte dos planos diretores, não são colocados em funcionamento. Concebidos em um momento de pouco investimento no setor, esses instrumentos são abandonados justamente no momento em que recursos públicos e 
privados inundam o mercado imobiliário, não se constituindo em qualquer forma de regulação do mercado, turbinado pela presença de vultuosos recursos e de grandes corporações.

A efetividade dos instrumentos de planejamento urbano dependem de um período de implantação, ao passo que a ação do capital imobiliário muitas vezes atua ao largo desse processo. A convergência de interesses públicos e privados, no âmbito político e econômico, reforçam o modelo de política urbana excludente, submetido à lógica do capital e não do interesse coletivo.

É nesse cenário que a proposta autogestionária na produção habitacional atua e constrói sua estratégia de lutas, empreendendo ações, ainda que pontuais, de resistência ao modelo dominante. 


\section{REFERÊNCIAS ${ }^{1}$}

ALFONSIN, Jacques. A função social da propriedade privada urbana como propriedade de funções. In: ALFONSIN, Betânia; FERNANDES, Édésio (Orgs.). Direito à moradia e segurança da posse no estatuto da cidade. Belo Horizonte: Fórum, 2004.

ARAGÃO, T. A.; CARDOSO, A. L. A reestruturação do setor imobiliário e o programa Minha Casa Minha Vida. In: Estado e capital imobiliário: convergências atuais na produção do espaço urbano brasileiro. Belo Horizonte: C/Arte, 2011.

ARANTES, P. F. Assessoria técnica para autogestão. In: SEMINÁRIO PRÁTICAS DE MORAR. CICLO INTERNACIONAL DE DEBATES - ONG CIDADE. Porto Alegre, Faculdade de Arquitetura/UFRGS, 9.12.2011. Disponível em:

$<$ www.youtube/watch?v=RFUaMisa90Y\&feature=relmfu $>$.

; USINA, Coletivo. Arquitetura, política e autogestão: um comentário sobre os mutirões habitacionais. Urbania, v. 3, p. 47-60, 2008.

BARANDIER JÚNIOR, José Renato da Gama. Acessibilidade da população alvo do programa habitacional para baixa renda na cidade do Rio de Janeiro. Rio de Janeiro: UFRJ/Coppe, 2012.

BARAVELLI, J. E. O cooperativismo uruguaio na habitação social de São Paulo. Das cooperativas Fucvam à Associação de Moradia Unidos de Vila Nova Cachoeirinha. Dissertação (Mestrado em Habitat) - Faculdade de Arquitetura e Urbanismo, Universidade de São Paulo, São Paulo, 2007. Disponível em:

<http://www.teses.usp.br/teses/disponiveis/16/16137/tde-20052010-141433/>. Acesso em: 20 nov. 2011.

BARROS, Mariana Cicuto. Autogestão na implementação de políticas habitacionais: 0 mutirão autogerido Brasilândia B23. Dissertação (Mestrado em Teoria e História da Arquitetura e do Urbanismo) - Escola de Engenharia de São Carlos, Universidade de São Paulo, São Carlos, 2011. Disponível em:

<http://www.teses.usp.br/teses/disponiveis/18/18142/tde-28072011-153425/>. Acesso em: 20 nov. 2011.

BASSUL, José Roberto. Reforma urbana e Estatuto da Cidade. EURE , v. 28, n. 84, Santiago, 2002. Disponível em: <http://www.scielo.cl/scielo.php?script=sci_arttext\&pid=SO250$71612002008400008 \&$ lng=es\&nrm=iso>. Acesso em: 10 mar. 2010.

BEDÊ, Mônica. Trajetória da formulação e implantação da política habitacional de Belo Horizonte na gestão da Frente BH Popular: 1993-1996, 2005. Dissertação (Mestrado em Geografia) - Instituto de Geociências da Universidade Federal de Minas Gerais, Belo Horizonte.

\footnotetext{
${ }^{1}$ De acordo com a Associação Brasileira de Normas Técnicas. NBR 6023
} 
BIASOTTO, Rosane; OLIVEIRA., F. L. O acesso à terra urbanizada nos planos diretores brasileiros. In: SANTOS JÚNIOR, O. A. dos; MONTANDON, Daniel Todtmann (Orgs.). Os planos diretores municipais pós estatuto da cidade: balanço crítico e perspectivas. Rio de Janeiro: Observatórios das metrópoles: Universidade Federal do Rio de Janeiro, 2011.

BOCCHINI, Maria Otília; SANTORO, Paula; ROLNIK, Raquel; CYMBALISTA, Renato; BRIANESI, Thaís. Vamos mudar nossas cidades? São Paulo: Instituto Pólis, 2002.

BONDUKI, N. G. Do projeto Moradia ao Minha Casa Minha Vida. Teoria e Debate, n. 82, maio/jun. 2009.

As duas fases da cidade brasileira. 2008c. Disponível em:

$<$ http://www.nabil.org.br/wp content/uploads/2012/09/ASDUASFACESDACIDADEBRASILEIRA2.pdf>.

; ROSSETTO, R. O plano nacional de habitação e os recursos para financiar a autogestão. Scripta Nova, v. 116, p. 33-38, Barcelona, 2008.

1992.

Habitação e autogestão - construindo territórios de utopia. Rio de Janeiro: Fase,

Origens da habitação social no Brasil. Arquitetura moderna, lei do inquilinato e difusão da casa própria. São Paulo: Estação Liberdade/Fapesp, 1998.

Política habitacional e inclusão social no Brasil: revisão histórica e novas perspectivas no governo Lula. Revista eletrônica de Arquitetura e Urbanismo, 01, São Paulo: Universidade São Judas Tadeu, 2008a.

. O boom imobiliário vai chegar à habitação de interesse social? Agência Estado, 15 de janeiro de $2008 b$.

BRASIL. Câmara dos Deputados. Coordenação de publicações. Estatuto das cidades: guia para a implementação pelos municípios e cidadãos: Lei n. 10.257, de 10 de julho de 2001. Rolnik, Raquel (Coord. Geral), 2. ed. Brasília, 2002.

Ministério das Cidades. Acesso à terra urbanizada: Implementação de planos diretores e regularização fundiária plena. Florianópolis, 2008.

. Ministério das Cidades. Política Nacional de Desenvolvimento Urbano, Brasília, 2004.

Ministério das Cidades. Resoluções da $\mathbf{1}^{\text {ạ }}$ Conferência Nacional das Cidades, Brasília, 2003.

Ministério das Cidades. Fundação João Pinheiro. Déficit Habitacional no Brasil, Ministério das Cidades. Belo Horizonte, 2007. 
. Ministério das Cidades. Plano diretor participativo. Guia para a elaboração pelos municípios e cidadãos. Brasília, 2004.

Ministério das Cidades. Plano nacional de habitação. Brasília, 2009.

. Ministério das Cidades. Planos locais de habitação de interesse social. CURSO A DISTÂNCIA - EAD-PLHIS. O processo de urbanização brasileira e a função social da propriedade urbana. Aula 01, 2007.

. Ministério das Cidades. Planos locais de habitação de interesse social. DENALDI, Rosana (Org.); FERREIRA, José Sette Whitaker. CURSO A DISTÂNCIA - EAD-PLHIS. O processo de urbanização brasileira e a função social da propriedade urbana.

CAMPOS, R. C. O preço da terra urbana e moradia de baixo custo. In: Estado e capital imobiliário: convergências atuais na produção do espaço urbano brasileiro. Belo Horizonte: C/Arte, 2011.

CARDOSO, A. L.; ARAGÃO, T. A.; ARAÚJO, Flávia. Habitação de interesse social: política ou mercado: Reflexos sobre a construção no espaço metropolitano. In: XIV ENCONTRO NACIONAL DA ASSOCIAÇÃO NACIONAL DE PÓS-GRADUAÇÃO E PESQUISA EM PLANEJAMENTO URBANO. Rio de Janeiro, 2011.

CBIC. Position paper. Terra urbanizada. Disponível em: <http://www.cbic.org.br/sala-deimprensa/position-papers/terra-urbanizada>.

COLETIVO USINA. Reforma urbana e autogestão na produção da cidade: história de um ciclo de lutas e desafios para a renovação da sua teoria e prática. In: Gestão pública e sociedade: fundamentos e políticas públicas de economia solidária, v. II - São Paulo: outras expressões, 2012.

CONTI, Alfio. A experiência da autogestão em Ipatinga: uma busca pelo conceito. Dissertação (Mestrado em Arquitetura Teoria e Prática do Projeto Arquitetônico)- Escola de Arquitetura da Universidade Federal de Minas Gerais, Belo Horizonte, 1999.

CORRÊA, Ricardo. Direito à terra e habitação. v. II, Rio de Janeiro: Fundação Bento Rubião, 2007.

COSTA, G. M.; MENDONÇA, J. G. Planejamento urbano no Brasil: trajetória, avanços e perspectivas. Belo Horizonte: Arte, 2008.

DE GRAZIA, G. Estatuto da cidade: uma longa história com vitórias e derrotas. In: OSÓRIO, L. M. (Org.). Estatuto da cidade e reforma urbana: novas perspectivas para as cidades brasileiras. Porto Alegre: Sérgio Antônio Fabris Editor, 2002.

DINIZ, M. Sesmarias e posse de terras: política fundiária para assegurar a colonização brasileira. Publicado em junho de 2005. Disponível em: 
<http://www.historica.arquivoestado.sp.gov.br/materias/anteriores/edicao02/materia03>. Acesso em: 22 jan. 2013.

FAORO, R. Os donos do poder: formação do patronato político brasileiro. São Paulo: Globo, 3. ed. 10 a reimpr., 2001.

FASE. Mutirões autogestionários levantamento das obras - 1989 a 1995. São Paulo, 1995.

FERNANDES, E.; VALENÇA, M. M. Brasil urbano. Rio de Janeiro: Mauad, 2004.

FERNANDES, F. A revolução burguesa no Brasil - ensaio de interpretação sociológica. Rio de Janeiro: Zahar Editores, 1975.

FERREIRA, J. S. W. A cidade para poucos: breve história da propriedade urbana no Brasil. In: SIMPÓSIO INTERFACES DAS REPRESENTAÇÕES URBANAS EM TEMPOS DE GLOBALIZAÇÃO. Anais... Bauru, Unesp, 21 a 26 de agosto de 2005. Disponível em:

$<$ http://pt.scribd.com/doc/56678804/A-Cidade-Para-Poucos-breve-Historia-Da-PropriedadeUrbana-No-Brasil-JOAO-WHITAKER-1>.

FIX, M. A. B. Parceiros da exclusão: duas histórias da construção de uma "nova cidade" em São Paulo: Faria Lima e Água Espraiada. São Paulo: Boitempo, 2001.

. Financeirização e transformações recentes no circuito imobiliário no Brasil. Tese (Doutorado)- Instituto de Economia da Universidade Estadual de Campinas, 2011. Disponível em: <http://www.bibliotecadigital.unicamp.br/document/?code=000815022 >. Acesso em: 22 jan. 2013.

São Paulo cidade global: fundamentos financeiros de uma miragem. São Paulo: Boitempo, 2007.

GOHN, M. G. M. Movimentos sociais e lutas pela moradia. v. 1, São Paulo: Edições Loyola, 1991.

2009.

Novas teorias dos movimentos sociais. v. 1500, 2. ed. São Paulo: Edições Loyola,

FÓRUM NACIONAL DE REFORMA. Diversos autores. Texto aprovado no Encontro Nacional pelo Direito à Cidade, julho de 2002. Disponível em:

<http://www.forumreformaurbana.org.br/index.php/documentos-do-fnru/41-cartas-emanifestos/134-carta-para-implementacao-do-estatuto-da-cidade.html>. Acesso em: 15 fev. 2013.

GORENDER, J. Regime territorial no Brasil escravista. In: O escravismo colonial. 5. ed. rev. e ampl. São Paulo: Ática, 1988.

INSTITUTO CIDADANIA. Projeto moradia. São Paulo: IC, 2000. 
KLECHEN, C. F.; BARRETO, R. O.; PAUL, A. P. P. Pilares para a compreensão da autogestão: o caso de um programa de habitação da Prefeitura de Belo Horizonte. Rio de Janeiro, 2010.

LABHAB ; FUPAM. Produzir casas ou construir cidades? Desafios para um novo Brasil urbano. Parâmetros de qualidade para a implementação de projetos habitacionais e urbanos. Coordenador: João Sette Whitaker Ferreira. São Paulo , 2012.

LAGO, L. Autogestão da moradia na superação da periferia urbana: conflitos e avanços. Revista E-metropoles, v. 5, p. 6-12, 2011.

(Org.) Autogestão habitacional no Brasil: utopias e contradições. Rio de Janeiro: Rede Nacional INCT. Observatório das Metrópoles, 2012.

MARICATO, E. Brasil, cidades: alternativas para a crise urbana. v. 1, 3. ed. Petrópolis/RJ: Vozes, 2001.

O nó da terra. In: O impasse da política urbana no Brasil. Petrópolis: Vozes, 2011.

; MOREIRA, T. ; HADDAD, E. ; SANDRONI, P. Preço de desapropriação de terras:

limites às políticas públicas nas áreas de habitação, meio ambiente e vias públicas em São Paulo. 2000. Relatório de pesquisa.

MARTINS, J. S. O cativeiro da terra. 9. ed. rev. e ampl., São Paulo: Contexto, 2010.

MELO, M. A. B. Legitimação de posse dos imóveis urbanos e o direito à moradia. Rio de Janeiro: Lumen Juris Editora, 2008.

MINISTÉRIO DAS CIDADES. Contextualização do Plano Nacional de Habitação:

análise e sistematização do contexto habitacional atual, constrangimentos, potencialidades e cenários possíveis. 2008. Disponível em:

$<\mathrm{http}$ ///www.google.com.br/url?sa=t\&rct=j\&q=\&esrc=s\&frm=1\&source=web\&cd=1\& cad=rja\&ved=0CDMQFjAA\&url=http\%3A\%2F\%2Fwww.usp.br\%2Ffau\%2Fdepprojeto\% 2Flabhab\%2Fbiblioteca\%2Fprodutos\%2Fplanhab_produto2_vol2.pdf\&ei=_38aUYraM 4Tq8gS31IH4CQ\&usg=AFQjCNF9uPvLkSuVdT5OTA3pL3SURLX2nw\&sig2=iTczc89KEfYY x6lpjHDgtA\&bvm=bv.42261806,d.eWU>.

MOREIRA, Fernanda Accioly. O lugar da autogestão no governo Lula. Dissertação (Mestrado em Hábitat) - FAU-USP, São Paulo, 2009.

NOGUEIRA, J. A. S. C.; PIRES, M. C. S. O Federalismo brasileiro e a lógica cooperativacompetitiva. In: Consórcios públicos: Instrumento do federalismo cooperativo. Belo Horizonte: Fórum, 2008.

OLIVEIRA. F. L. O acesso à terra urbanizada nos planos diretores brasileiros. In: SANTOS JÚNIOR, Orlando Alves dos; MONTANDON, Daniel Todtamann (Orgs.) Os planos diretores municipais pós estatuto da cidade: balanço crítico e perspectivas. Rio de Janeiro:

Observatórios das Metrópoles. Universidade Federal do Rio de Janeiro, 2011. 
ORTIZ, E; ZARATE, M.L. (compiladores) Vivitos y coleando. 40 años trabajando por el hábitat popular en América Latina.HIC-AL, Universidad Autónoma Metropolitana, México, 2002.

De la Marginación a la Ciudadania: 38 Casos de Producción y Gestión Social del Habitat, Forum Barcelona 2004, Habitat International Coalition y Diálogos Ciudad y Ciudadanos del siglo XXI . Ciudad de México, 2004

PALUMBO, A. P.; PEREIRA, M. A.; BALTRUSIS, N. (Orgs.). Direito à moradia: uma contribuição para o debate. São Paulo: UMM-SP: FASE: Ed. Paulinas, 1992.

PARMEZANI, E. Especulação explode nas periferias. Caros amigos. v. 190, p. 10 - 13, 2013.

PAZ, R. D. O. Fundo nacional de moradia popular: marco histórico de participação da união dos movimentos de moradia de São Paulo. Dissertação (Mestrado)- Pontifícia Universidade Católica de São Paulo (PUC-SP), São Paulo, 1996.

PRADO, C. Evolução política do Brasil. São Paulo: Brasiliense, 1953.

RIBEIRO, L. C. Q.; CARDOSO, A. L. Reforma urbana e gestão democrática: promessas e desafios do Estatuto da Cidade. Rio de Janeiro: Fase, 2003.

RIBEIRO, L. C. Q. SANTOS JÚNIOR, O. A. (Org.). As Metrópoles e a Questão Social Brasileira. Rio de Janeiro: Revan, 2007.

RODRIGUES, E. L.; BARBOSA, B. R. Movimentos populares e o estatuto da cidade In: $\mathbf{O}$ estatuto da cidade: um comentário. São Paulo: Cities Alliance, 2010.

ROLNIK, R.; CYMBALISTA, R.; NAKANO, K. Solo urbano e habitação de interesse social: A questão fundiária na política habitacional do país. 2008. Disponível em:

<http://raquelrolnik.wordpress.com>.

Solo urbano e habitação de interesse social: a questão da moradia nos planos diretores participativos. In: MORAIS, Maria da Piedade (Org.). Política habitacional e assentamentos informais. Brasília: Ipea. No prelo.

; SANTORO, P. Zonas especiais de interesse social (Zeis) em cidades brasileiras trajetória recente de implementação de um instrumento de política fundiária. Lincoln Institute of Land Policy, 2012. No prelo.

; SAULE Jr., N. Estatuto da cidade: guia para a implementação pelos municípios e cidadãos. 2. ed. Brasília: Câmara dos Deputados, 2002.

A cidade e a lei: legislação, política urbana e territórios na cidade de São Paulo. Fapesp, 2007.

SALLES. A. V. P. Regularização fundiária: questões enfrentadas pelos grandes centros urbanos e dificuldades procedimentais para melhor organização das cidades. In: ROLNIK, 
Raquel et. al. Regularização fundiária sustentável: conceitos e diretrizes. Ministério das Cidades, 2004.

SANTORO, P.; BONDUKI, N. G. O desafio do parcelamento do solo a partir do periurbano: a composição do preço da terra na mudança de uso do solo rural para urbano. In: XIII ENANPUR - ENCONTRO NACIONAL DA ANPUR. Anais Florianópolis: Anpur, 2009. CD-ROM.

SANTOS JR., O. A. dos; MONTANDON, D. T. Os planos diretores pós-estatuto da cidade: balanço crítico e perspectivas. Rio de Janeiro: Letra Capital e Observatório das Cidades: IPPUR/UFRJ, 2011.

Reforma urbana: desafios para o planejamento como práxis transformadora. In: COSTA, Geraldo M.; MENDONÇA, Jupira G. de (Orgs.). Planejamento urbano no Brasil: trajetórias, avanços e perspectivas. Belo Horizonte: C/Arte, 2008.

SILVA, H. M. B. Terra e moradia: que papel para o município? Tese (Doutorado)- FAU-USP, São Paulo, 1997.

SINGER, P. O uso do solo urbano na economia capitalista. In: MARICATO, E. A produção capitalista da casa (e da cidade) no Brasil industrial. 2. ed., São Paulo: Alfa-Ômega, 1982.

Introdução à economia solidária. São Paulo: Fundação Perseu Abramo, 2002.

SMITH. R. Propriedade da terra e transição: Estudo da formação da propriedade privada da terra e transição para o capitalismo no Brasil. 2. ed. São Paulo: Brasiliense, 2008.

SNH/MCIDADES. Como delimitar e regulamentar Zonas Especiais de Interesse Social - ZEIS em vazios urbanos. Brasília, 2009.

SPU, Balanço das atividades dos Grupos de Trabalho criados no âmbito da SPU, para destinação de imóveis da União em apoio à política de Habitação de Interesse Social, Brasília, 2012.

UMM-SP. Cartilha de formação de lideranças, São Paulo, 2010. Mimeografado.

UNMP. União Nacional por Moradia Popular: um pouco de nossa história de luta pela transformação da sociedade. In: Organización y lucha de la Secretaria Latino Americana de la vivienda popular. Caracas. No prelo.

VARELA, L. B. Das sesmarias à propriedade moderna: um estudo de história do direito brasileiro. Rio de Janeiro: Renovar, 2005.

VÁRIOS autores. Derecho al suelo y la ciudad en América Latina La realidad y los caminos posibles. Centro Cooperativo Sueco, San José, 2012.

. El camino posible producción social del habitat en América Latina. Centro

Cooperativo Sueco, San José, 2011. 


\section{DECRETOS, LEIS E PROJETOS DE LEI}

Decreto no 6962/2009, de 17 de setembro de 2009 .

Decreto no 7.499, de 16 de junho de 2011.

Decreto no 7.795 de 24 de agosto de 2012.

Lei ㅇ 10.257/2001 - Estatuto da Cidade

Lei ㅇ 10.391/2004

Lei o 11.124/2005 - Sistema Nacional de Habitação de Interesse Social

Lei no 11.977, de 7 de julho de 2009.

Lei $n$ ㅇ 11.888 , de 24 de dezembro de 2008

Lei no 12.424, de 16 de junho de 2011.

Medida provisória no 459, de 25 de março de 2009.

Portaria Interministerial no 326, de 31 de agosto de 2009 .

Portaria Interministerial no 484, de 28 de setembro de 2009.

Portaria 80, de 26 de março de 2008

Resolução Normativa no 414, de 9 de setembro de 2010, da Agência Nacional de Energia Elétrica (Aneel)

\section{FAR - MCMV - PNHU}

Portaria n. 139, de 13 de abril de 2009, do Ministério das Cidades.

Portaria n. 325, de 7 de julho de 2011.

Portaria 465, de 3 de outubro de 2011, do Ministério das Cidades.

Portaria n. 546, de 23 de novembro de 2011.

FDS - MCMV Entidades 
Instrução Normativa n. 36, de 15 de julho de 2009.

Instrução Normativa n. 34, de 28 de setembro de 2011.

Instrução Normativa n. 45, de 9 de novembro de 2012.

Portaria Interministerial n. 464, de 30 de setembro de 2011.

Portaria n. 355, de 29 de julho de 2011.

Portaria n. 618, de 14 de dezembro de 2010.

Resolução n. 141, de 10 de junho de 2009.

Resolução n. 182, de 18 de agosto de 2011.

Resolução n. 183, de 10 de novembro de 2011.

Resolução n. 190, de 7 de agosto de 2012.

Resolução n. 194, de 12 de dezembro de 2012.

FDS - PCS

Instrução Normativa n. 14, de 25 de março de 2008.

Instrução Normativa n. 39, de 28 de dezembro de 2005.

Resolução n. 121, de 9 de janeiro de 2008.

\section{DOCUMENTOS DE ENTIDADES}

CENTRO COOPERATIVO SUECO. Estratégia regional para o acesso ao solo urbano. San José, 2009.

1aㅡ CONFERÊNCIA DAS CIDADES. Carta das cidades. São Paulo, 1999.

FÓRUM NACIONAL DE REFORMA URBANA. Manifesto da marcha nacional da reforma urbana. Brasília, 2005.

Investimentos do PAC não garantem direito à moradia digna. Rio de Janeiro, 2007.

. Boletim n. 41. Rio de Janeiro, 2007. 
Boletim n. 54. Rio de Janeiro, 2008.

. A reforma urbana e o pacote habitacional. Boletim n. 59, Rio de Janeiro, 2009.

- A reforma urbana e o programa Minha Casa Minha Vida. Boletim n. 62. Rio de Janeiro, 2009.

. Carta mundial pelo direito à cidade. São Paulo, 2001.

. ENCONTRO NACIONAL PELO DIREITO À CIDADE. Carta para implementação do Estatuto da Cidade. julho de 2002.

Plataforma do direito à cidade e reforma urbana: caminho para cidades justas democráticas e sustentáveis. São Paulo, 2012.

FÓRUM NACIONAL DE REFORMA URBANA. Manifesto por mais moradia popular. Rio de Janeiro, 2008.

SECRETARIA LATINO AMERICANA DE LA VIVIENDA POPULAR. Declaración de Quito. Quito, 2011.

. XIII ENCONTRO. Documento final. Caracas, 2011.

. Manifiesto Que es SELVIPi, Buenos Aires, 2009.

UNIÃO DOS MOVIMENTOS DE MORADIA. Bases de uma política habitacional. São Paulo, 1994.

. Ofício à Diretoria de Desenvolvimento Urbano da Caixa. São Paulo, 1999.

2001. Contribuição municipal para a conferência municipal de habitação. São Paulo, . 6 ENCONTRO ESTADUAL DE MORADIA - HABITAÇÃO E INCLUSÃO SOCIAL.

Relatório. 2001, São Paulo, 2001.

. Em defesa do acesso às terras públicas para moradia popular. São Paulo, 2012.

. Carta aberta à prefeitura municipal de São Paulo. São Paulo, 2001.

. Sem teto exigem agilidade na aprovação dos projetos de HIS e terrenos vazios para o programa Minha Casa Minha Vida Entidades. São Paulo, 2011.

Ato público minha casa e minha vida são no centro. São Paulo, 2009. 
UNIÃO NACIONAL POR MORADIA POPULAR. SEMINÁRIO NACIONAL DA UNMP. Carta. Arapongas, 1998.

1999.

Proposta para mutirões no programa de arrendamento residencial. São Paulo,

. ENCONTRO nACIONAL DE MORADIA POPULAR. Relatório. Paripueira, 2002.

Ofício ao Ministério das Cidades e Caixa. São Paulo, 2003.

. ENCONTRO NACIONAL DE MORADIA POPULAR - OCUPAR, RESISTIR E CONSTRUIR O

DIREITO À MORADIA E À CIDADE. Relatório. Nova Iguaçu, 2004.

. Carta de Pernambuco. Recife, 2004.

. 10ํENCONTRO NACIONAL DE MORADIA POPULAR. Resolução. Salvador, 2006.

UNIÃO NACIONAL POR MORADIA POPULAR. Carta de São Paulo. São Paulo, 2006.

.. Carta Aberta - UNMP nas ruas em defesa da moradia e da reforma urbana. São Paulo, 2007.

. Ofício ao Presidente da República. São Paulo, 2007.

. Ofício ao Presidente a República. São Paulo, 2008.

. Enquanto morar for um privilégio, ocupar é um direito. São Paulo, 2008.

. 11ํㅡㄹ ENCONTRO NACIONAL DE MORADIA POPULAR - Produção social da moradia:

desafio para a política de habitação. Resolução. Goiânia, 2008.

. SEMINÁRIO NACIONAL ACESSO À TERRA URBANIZADA. Relatório. São Paulo, 2008.

. Considerações ao PlanHab. São Paulo, 2008.

. Lula recebe movimentos populares em audiência. Brasília, 2009.

. REUNIÃO COM A MINISTRA DILMA ROUSSEF. Relato. Brasília, 2009.

. Sugestões para a reformulação do Crédito Solidário. São Paulo, 2009.

. Jornada em defesa da moradia popular. São Paulo, 2009.

. SEMINÁRIO NACIONAL DE BALANÇO DA IMPLEMENTAÇÃO DOS INSTRUMENTOS

URBANOS PARA HABITAÇÃO POPULAR NOS PLANOS DIRETORES. Relatório. Belo Horizonte, 2009. 
. Minha Casa Minha Vida: Tá na hora de sair do papel. São Paulo, 2010.

. Propostas para o Minha Casa Minha Vida 2. São Paulo, 2011.

. SECRETARIA-GERAL DA PRESIDÊNCIA. Ofício. São Paulo, 2011.

2011.

. 12 ENCONTRO NACIONAL DE MORADIA POPULAR . Resolução. Belo Horizonte,

. SECRETARIA NACIONAL DE HABITAÇÃO. Ofício. São Paulo, 2012.

. Dia de mobilização e luta pela moradia - quanto mais burocracia, menos moradia. São Paulo, 2012.

. MINISTÉRIO DAS CIDADES E CAIXA. Ofício. São Paulo, 2012.

. O que muda com a nova resolução do Ministério das Cidades. São Paulo, 2012.

UNIÃO NACIONAL POR MORADIA POPULAR. Carta à SPU. Brasília, 2012.

\section{SITES CONSULTADOS}

<http://www.camara.gov.br/internet/sitaqweb/TextoHTML.asp?etapa=5\&nuSessao=319.1.5 3.0

\&nuQuarto $=47 \&$ nuOrador $=2 \&$ nulnsercao $=11 \&$ dt HorarioQuarto $=10: 32 \&$ sgFaseSessao $=O D$ \&Data=13/11/2007\&txApelido=VICENTINHO, PT-SP\&txFaseSessao=Ordem do Dia \&txTipoSessao=Extraordinária - CD\&dtHoraQuarto=10:32\&txEtapa=>.

<http://www.maringaimoveis.com.br/Noticias/Index/234743>.

<http://www.camara.gov.br/proposicoesWeb/prop_mostrarintegra;jsessionid=A50F2C4611 E4CEA9AD48BB136818CC5A.node2 ?codteor $=646031 \&$ filename=Tramitacao$\mathrm{EMC}+87 / 2009+\mathrm{MPV} 45909+\% 3 \mathrm{D} \% 3 \mathrm{E}+\mathrm{MPV}+459 / 2009>$. Acesso em: 7 jan. 2013.

<http://www.valor.com.br/carreira/1078112/construcao-civil-inova-para-atrair-mao-deobra>.

<http://www.gazetadopovo.com.br/imobiliario/conteudo.phtml?id=1329110\&tit=Precoslimitam-alcance-do-Minha-Casa>. Acesso em: 6 jan. 2013.

<www.forumreformaurbana.org.br>. Acesso em: 9 out. 2012.

<http://www.cbic.org.br/sala-de-imprensa/position-papers/terra-urbanizada>. Acesso em: 2 jan. 2012. 
<http://www.brasildefato.com.br/node/11604\#.UPwpEx72IFE.facebook>. Acesso em: 21 jan. 2012.

<www.cdhu.sp.gov.br>. Acesso em: 20 jun. 2012.

<http://www.forumreformaurbana.org.br/index.php/documentos-do-fnru/41-cartas-emanifestos/133-carta-mundial-pelo-direito-a-cidade.html>. Acesso em: 20 dez. 2012.

<http://www.fazenda.gov.br/portugues/documentos/2012/Apresenta\%C3\%A7\%C3\% A3o_Constru\%C3\%A7\%C3\%A3o_Civil_Final.pdf>.

<http://mail.camara.rj.gov.br/APL/Legislativos/discvot.nsf/8b99ca38e07826db03256 5300046fdf1/0486a67a21c5c745832578c30060c6c7?OpenDocument >. 
$\overrightarrow{ }$

\begin{tabular}{|c|c|c|c|c|c|c|c|c|c|c|}
\hline 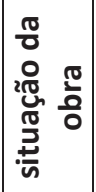 & 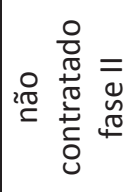 & 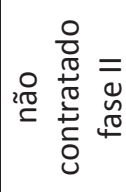 & 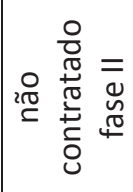 & $\begin{array}{l}\frac{\pi}{O} \\
\frac{O}{3} \\
\frac{U}{0} \\
0\end{array}$ & 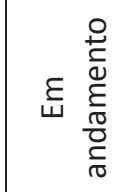 & $\begin{array}{l}\frac{\pi}{0} \\
\frac{O}{3} \\
\frac{E}{0} \\
0\end{array}$ & $\begin{array}{l}\frac{\pi}{0} \\
\frac{O}{3} \\
\frac{E}{0} \\
0\end{array}$ & $\begin{array}{l}\frac{\pi}{0} \\
\frac{O}{3} \\
\\
0 \\
0\end{array}$ & 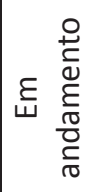 & 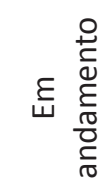 \\
\hline 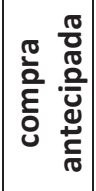 & $\frac{E}{n}$ & $\frac{\varepsilon}{n}$ & $\frac{\varepsilon}{n}$ & $\stackrel{2}{2 \pi}$ & 20 & 2i⿱ & 2i⿱ & i⿱乛⿻ & $\underset{20}{\check{20}}$ & 200 \\
\hline 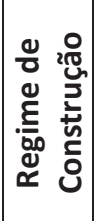 & 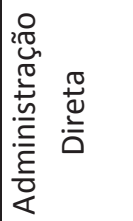 & 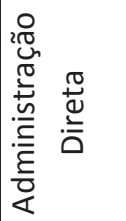 & 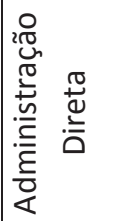 & 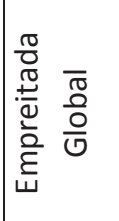 & 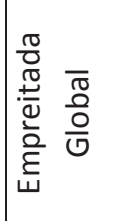 & 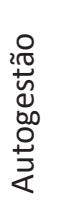 & 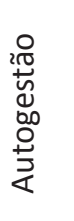 & 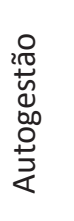 & 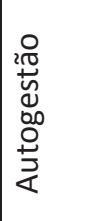 & 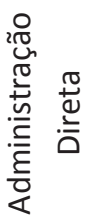 \\
\hline $\begin{array}{l}\frac{0}{0} \\
\frac{\pi}{0} \\
\frac{0}{\pi} \\
\frac{\pi}{0} \\
\Sigma\end{array}$ & 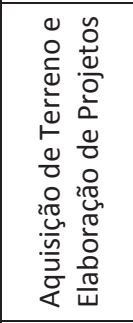 & 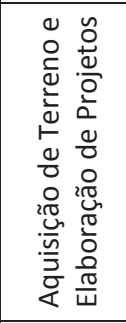 & 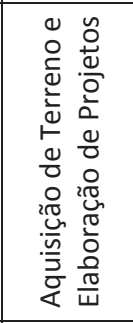 & 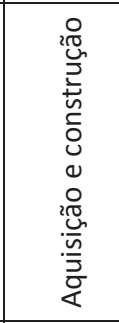 & 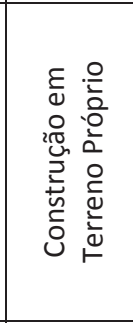 & 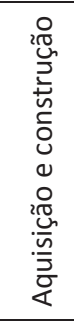 & 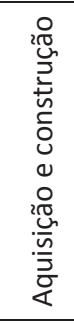 & 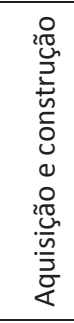 & 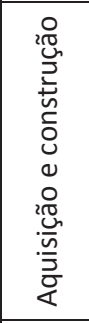 & 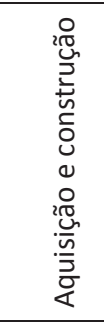 \\
\hline 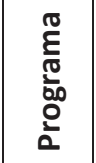 & 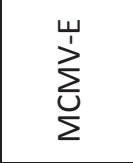 & $\sum_{\sum}^{u}$ & 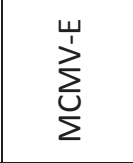 & $\sum_{\sum}^{u}$ & $\sum_{\sum}^{u}$ & $\tilde{y}$ & $\tilde{\swarrow}$ & $\tilde{\complement}$ & y & 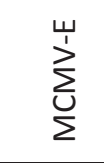 \\
\hline $\begin{array}{l}\frac{\sigma}{00} \\
\frac{0}{0} \\
\stackrel{0}{0} \\
i=\end{array}$ & $\begin{array}{l}\tilde{0} \\
\tilde{J} \\
\tilde{J}\end{array}$ & $\begin{array}{l}\widetilde{n} \\
\widetilde{n} \\
\widetilde{U}\end{array}$ & $\begin{array}{l}\text { 怘 } \\
\text { ల్ర }\end{array}$ & $\begin{array}{l}\stackrel{0}{0} \\
0 \\
\frac{0}{\sigma}\end{array}$ & 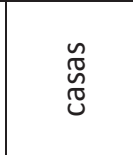 & $\begin{array}{l}\tilde{0} \\
\tilde{J} \\
\tilde{J}\end{array}$ & $\begin{array}{l}\tilde{0} \\
\tilde{J} \\
\tilde{J}\end{array}$ & $\begin{array}{l}\tilde{J} \\
\tilde{J} \\
\widetilde{U}\end{array}$ & $\begin{array}{l}\text { 芯 } \\
\text { ల్ }\end{array}$ & 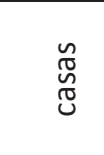 \\
\hline 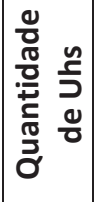 & ঃ & ঃ & ¿ & 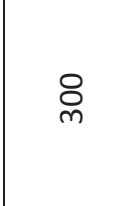 & 옥 & 옴 & 号 & 옥 & 号 & 옥 \\
\hline 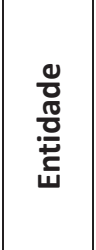 & 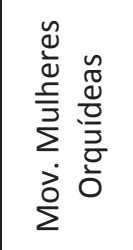 & 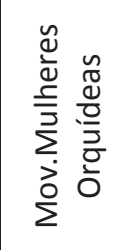 & 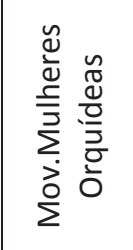 & 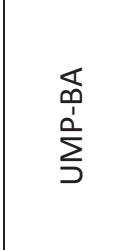 & 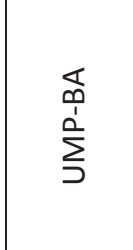 & $\begin{array}{l}\text { O } \\
\bigcup \\
\sum_{\text {品 }}\end{array}$ & $\begin{array}{l}\text { O } \\
\bigcup \\
\sum_{\text {品 }}\end{array}$ & $\begin{array}{l}\text { O } \\
\text { 足 } \\
\sum_{\text {岁 }}\end{array}$ & 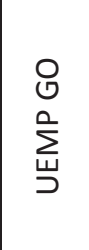 & 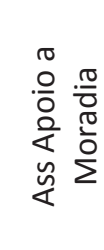 \\
\hline 岇 & $\sum_{<}$ & $\sum_{<}$ & $\sum_{<}$ & ৫ & ৫ & ০ ৩ & ০ ৩ & ᄋ ৩ & ᄋ ৩ & $\stackrel{\nwarrow}{\Sigma}$ \\
\hline $\begin{array}{l}\frac{0}{\frac{0}{2}} \\
\frac{0}{\frac{0}{5}} \\
\frac{5}{\Sigma}\end{array}$ & $\begin{array}{l}\frac{n}{J} \\
\frac{\pi}{\pi} \\
\frac{\pi}{\pi}\end{array}$ & $\begin{array}{l}\stackrel{n}{0} \\
\stackrel{0}{0} \\
\frac{\pi}{n} \\
\Sigma\end{array}$ & $\begin{array}{l}\frac{n}{7} \\
\stackrel{\pi}{0} \\
\frac{\pi}{\pi} \\
\sum\end{array}$ & 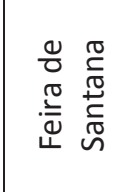 & 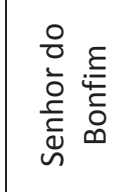 & 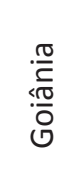 & 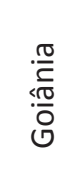 & 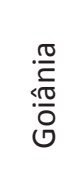 & 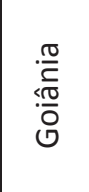 & 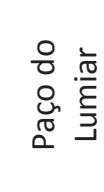 \\
\hline 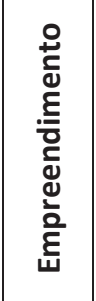 & $\begin{array}{l}\vec{y} \\
\overline{0} \\
\frac{d}{0} \\
\frac{0}{\bar{O}} \\
\frac{\overline{0}}{0} \\
0\end{array}$ & $\begin{array}{l}N \\
0 \\
0 \\
\frac{0}{0} \\
\frac{0}{3} \\
0 \\
0 \\
0\end{array}$ & 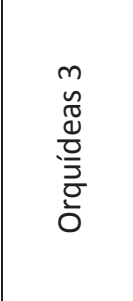 & 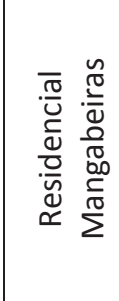 & 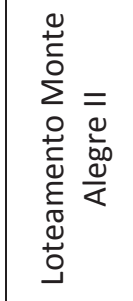 & 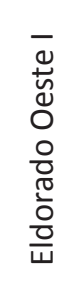 & 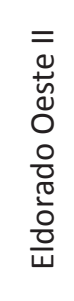 & 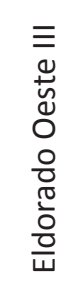 & 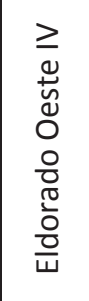 & 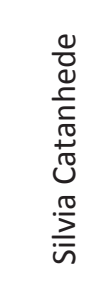 \\
\hline
\end{tabular}


$\stackrel{\infty}{\sim}$

\begin{tabular}{|c|c|c|c|c|c|c|c|c|c|c|}
\hline 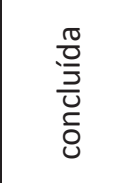 & $\begin{array}{l}\frac{\tilde{\sigma}}{\bar{z}} \\
\frac{\bar{\sigma}}{\tilde{\sigma}}\end{array}$ & $\begin{array}{l}\frac{\pi}{\frac{\pi}{\bar{z}}} \\
\frac{\bar{z}}{\mathrm{~g}}\end{array}$ & $\begin{array}{l}\frac{0}{\frac{0}{5}} \\
\frac{\bar{z}}{5}\end{array}$ & 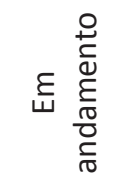 & 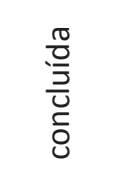 & 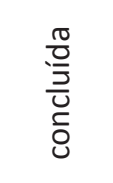 & $\begin{array}{l}\frac{\tilde{m}}{\underline{\underline{z}}} \\
\frac{\bar{z}}{\mathrm{~g}}\end{array}$ & $\begin{array}{l}\frac{\pi}{\frac{\pi}{\bar{z}}} \\
\frac{\bar{c}}{5}\end{array}$ & 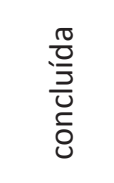 & 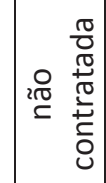 \\
\hline 兑 & 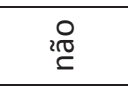 & 兽 & 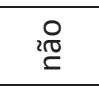 & 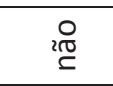 & 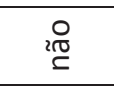 & 鄫 & 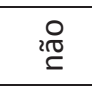 & 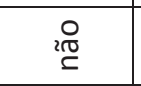 & 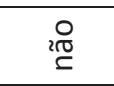 & 兽哭 \\
\hline 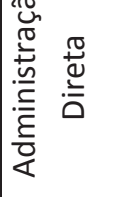 & 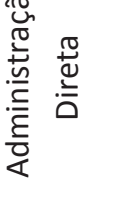 & 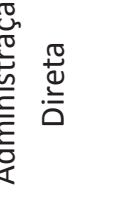 & 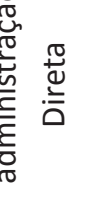 & 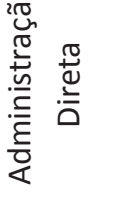 & 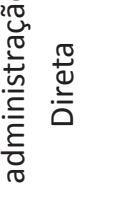 & 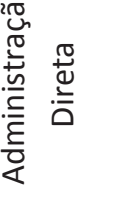 & 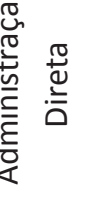 & 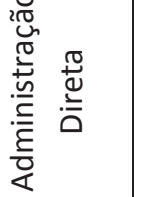 & 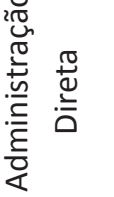 & $\mid$ \\
\hline 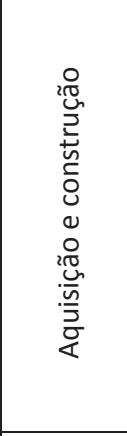 & 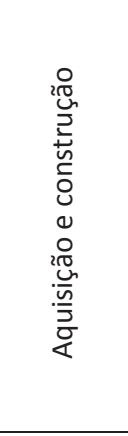 & 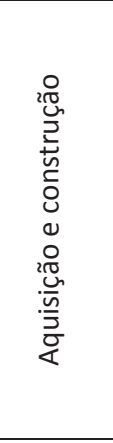 & 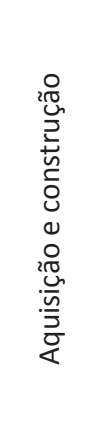 & 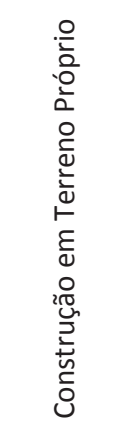 & 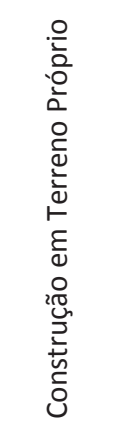 & 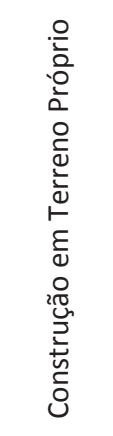 & 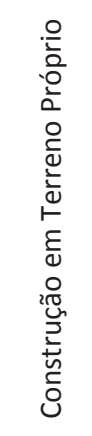 & 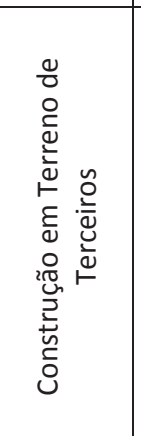 & 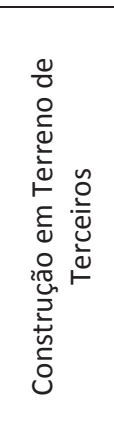 & 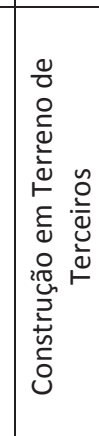 \\
\hline 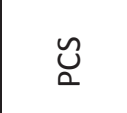 & $\check{\check{L}}$ & $\ddot{\Xi}$ & $\check{\check{L}}$ & $\check{z}$ & $\check{y}$ & $\check{y}$ & $\check{Z}$ & $\check{z}$ & $\check{z}$ & س \\
\hline 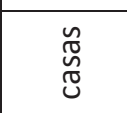 & 嘈 & 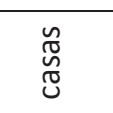 & 㩊 & 总 & 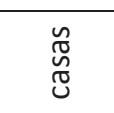 & 㩊 & 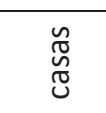 & $\frac{\stackrel{o}{o}}{\frac{0}{\sigma}}$ & $\frac{\mathrm{o}}{\frac{0}{\sigma}}$ & 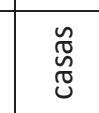 \\
\hline 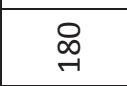 & $\stackrel{\circ}{\circ}$ & $\stackrel{్}{\circ}$ & $\stackrel{g}{g}$ & \& & $\stackrel{t}{\omega}$ & $\stackrel{8}{\circ}$ & $\stackrel{\circ}{\circ}$ & $\Xi$ & $\Xi$ & $\stackrel{\infty}{\square}$ \\
\hline 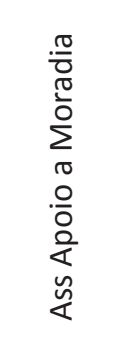 & 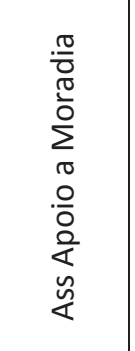 & 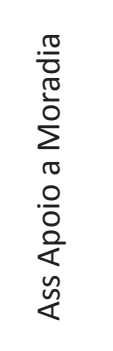 & 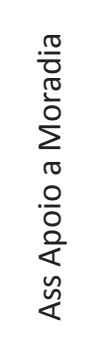 & 总 & 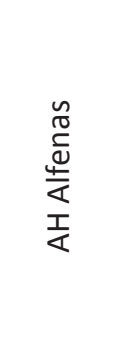 & 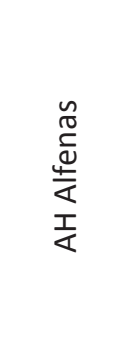 & 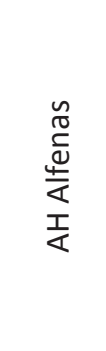 & 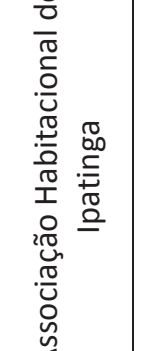 & 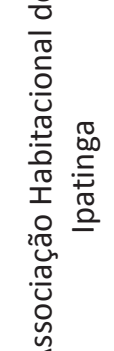 & 点 \\
\hline$\frac{\pi}{\Sigma}$ & $\frac{\pi}{2}$ & $\frac{\pi}{\Sigma}$ & $\frac{\pi}{\Sigma}$ & $\frac{0}{\Sigma}$ & $\stackrel{0}{\Sigma}$ & $\frac{0}{\Sigma}$ & $\stackrel{0}{\Sigma}$ & $\frac{O}{\Sigma}$ & $\stackrel{0}{\Sigma}$ & w \\
\hline 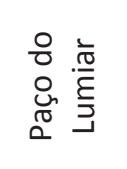 & 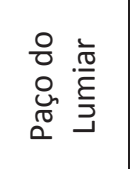 & 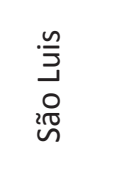 & 总 & 兽 & 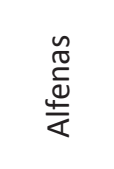 & 总 & 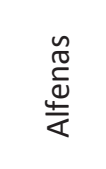 & $\begin{array}{l}\text { 总 } \\
\underline{\underline{\underline{w}}} \\
\underline{\underline{\underline{m}}}\end{array}$ & 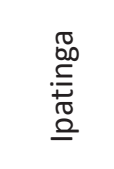 & 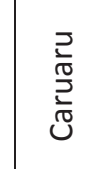 \\
\hline 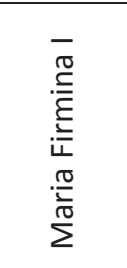 & 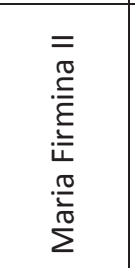 & 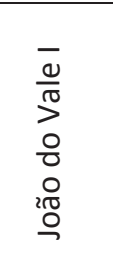 & 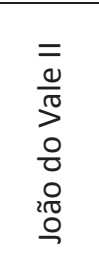 & 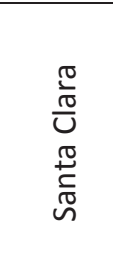 & 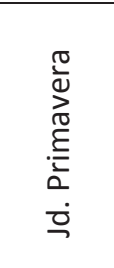 & 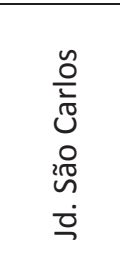 & 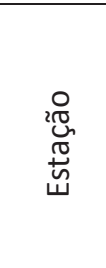 & 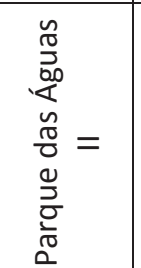 & 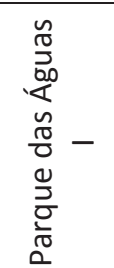 & \begin{tabular}{|l|}
$\overline{\overline{0}}$ \\
$\overline{\bar{z}}$ \\
$\bar{\partial}$ \\
$\bar{o}$ \\
$\bar{z}$ \\
$\bar{y}$
\end{tabular} \\
\hline
\end{tabular}




\begin{tabular}{|c|c|c|c|c|c|c|c|c|c|c|c|c|c|c|}
\hline 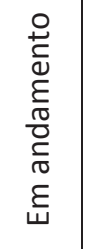 & 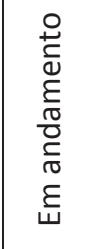 & 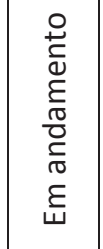 & 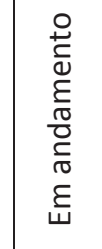 & 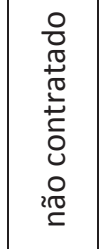 & 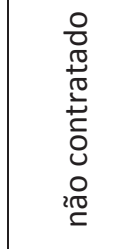 & 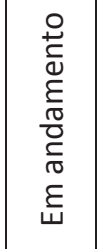 & 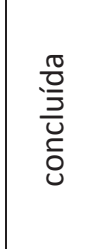 & 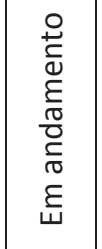 & 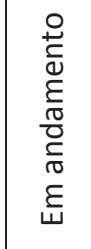 & 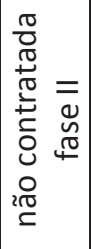 & 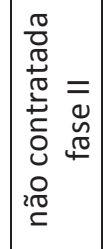 & 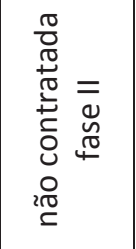 & 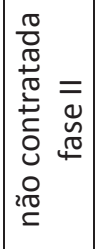 & 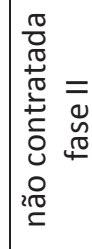 \\
\hline \begin{tabular}{ll|}
$\stackrel{0}{c}$ \\
\end{tabular} & $\begin{array}{ll}\stackrel{\circ}{c} \\
\end{array}$ & 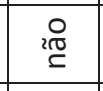 & 粱 & $\frac{\varepsilon}{\bar{n}}$ & 离 & 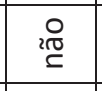 & 离 & $\frac{E}{\bar{n}}$ & 离 & $\frac{\varepsilon}{\bar{n}}$ & $\frac{\varepsilon}{\bar{n}}$ & $\frac{\varepsilon}{\bar{n}}$ & $\frac{\varepsilon}{\bar{n}}$ & $\frac{\varepsilon}{\bar{n}}$ \\
\hline 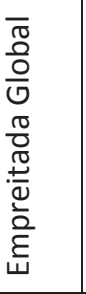 & 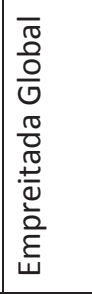 & 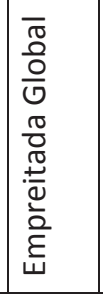 & 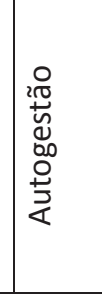 & 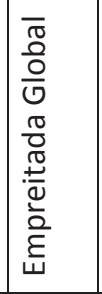 & 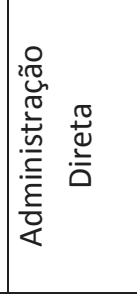 & 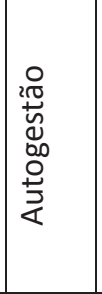 & 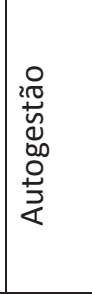 & 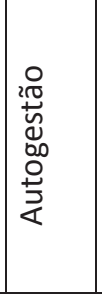 & 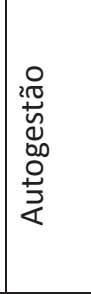 & 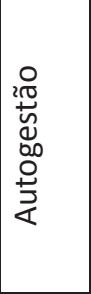 & 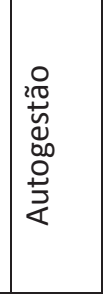 & 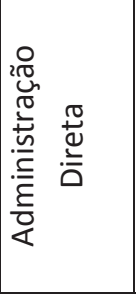 & 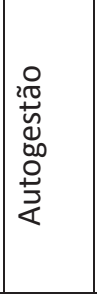 & 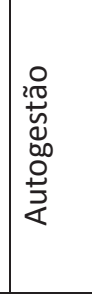 \\
\hline 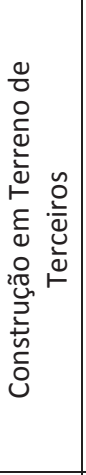 & 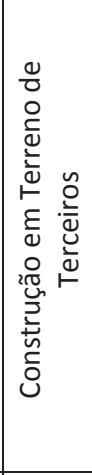 & 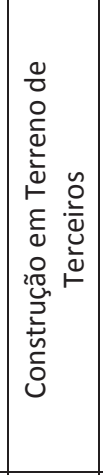 & 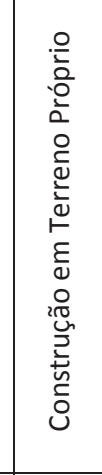 & 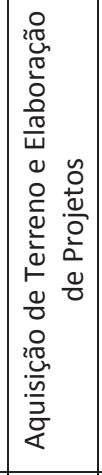 & 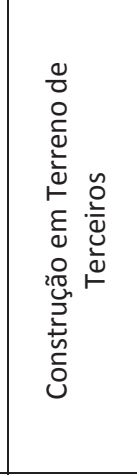 & 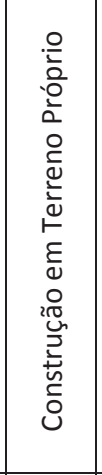 & 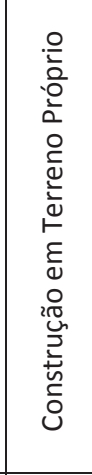 & 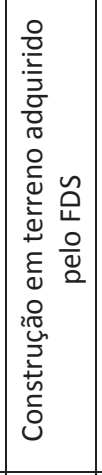 & 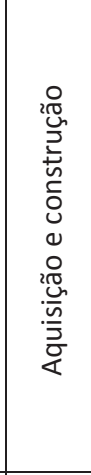 & 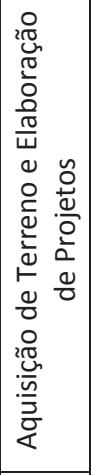 & 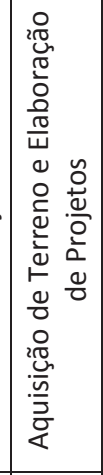 & 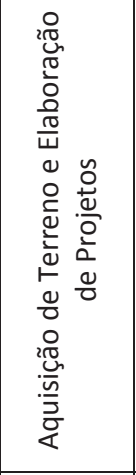 & 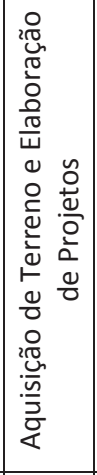 & 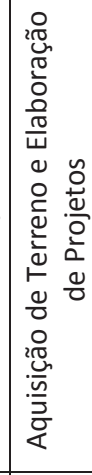 \\
\hline$\sum_{0}$ & $\sum_{\sum}^{1} \omega$ & $\sum_{\sum}^{1} \omega$ & $\sum_{\sum}^{1} \omega$ & $\sum_{\sum}^{1} \omega$ & 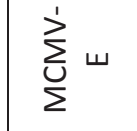 & $\sum_{\sum}^{\dot{\sum}} \omega^{\prime}$ & $\check{O}$ & $\sum_{\sum}^{\dot{\sum}} \omega^{\prime}$ & $\check{O}$ & $\sum_{\Sigma}^{\prime}$ & $\sum_{\sum}^{1} \omega$ & $\sum_{\sum}^{i} \omega$ & $\sum_{\Sigma}^{\prime} \omega$ & 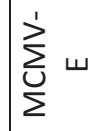 \\
\hline 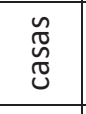 & 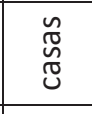 & 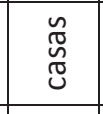 & 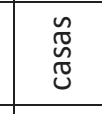 & \begin{tabular}{|l|}
$\frac{0}{0}$ \\
\multirow{0}{*}{} \\
\end{tabular} & $\frac{\stackrel{0}{\circ}}{\frac{0}{\pi}}$ & 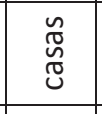 & $\begin{array}{l}\frac{\Delta}{0} \\
\frac{\Delta}{\pi}\end{array}$ & \begin{tabular}{|l|}
$\frac{0}{0}$ \\
$\frac{0}{0}$ \\
\end{tabular} & $\begin{array}{l}\frac{\Delta}{0} \\
\frac{\Delta}{\pi}\end{array}$ & $\begin{array}{l}\frac{0}{0} \\
\frac{0}{\sigma 0}\end{array}$ & \begin{tabular}{l|}
$\frac{0}{0}$ \\
$\frac{\Delta}{\sigma}$ \\
\end{tabular} & $\frac{\substack{0 \\
\frac{0}{\sigma 0}}}{\pi}$ & $\begin{array}{l}\frac{0}{0} \\
\frac{0}{\pi}\end{array}$ & $\begin{array}{l}\frac{0}{0} \\
\frac{0}{\sigma}\end{array}$ \\
\hline$\infty$ & 号 & $\stackrel{\mathscr{q}}{ }$ & 号 & $\begin{array}{l}P \\
\end{array}$ & 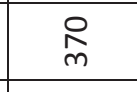 & 2 & 8 & 导 & ஃ & $\underset{\rightarrow}{\infty}$ & $\stackrel{\infty}{\rightarrow}$ & ৪্ল & 思 & $\stackrel{乛}{\%}$ \\
\hline 索 & $\frac{5}{8}$ & $\frac{5}{8}$ & 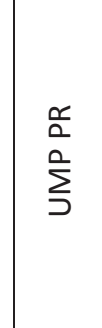 & 竞 & 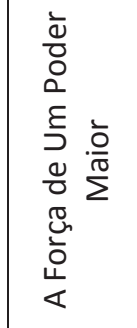 & 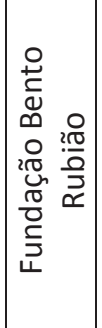 & $\sum_{\frac{5}{4}}^{\overrightarrow{5}}$ & 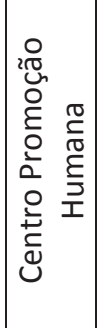 & \begin{tabular}{|l}
$\frac{u}{3}$ \\
$\frac{1}{\partial}$ \\
$\Sigma$
\end{tabular} & 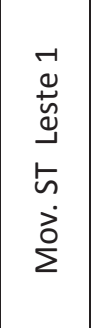 & $\begin{array}{l}\overrightarrow{0} \\
\underline{\underline{\Delta}} \\
\overrightarrow{5} \\
\vec{c} \\
\vec{c}\end{array}$ & 呈 & 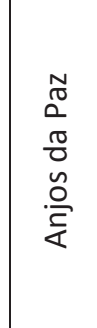 & 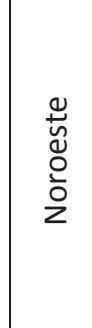 \\
\hline 뜸 & 씀 & шّ & $\frac{\alpha}{\alpha}$ & $\frac{\alpha}{\alpha}$ & $\frac{\alpha}{\alpha}$ & $\vec{\alpha}$ & $\bar{s}$ & i & $\dot{s}$ & is & ì & ì & 高 & is \\
\hline 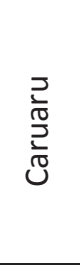 & 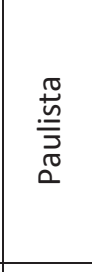 & 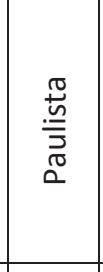 & $\begin{array}{l}\frac{\pi}{0} \\
\frac{0}{\pi} \\
\frac{0}{2} \\
\frac{3}{4}\end{array}$ & 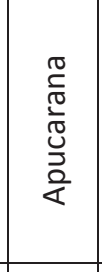 & 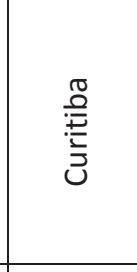 & 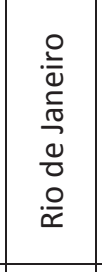 & 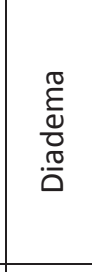 & 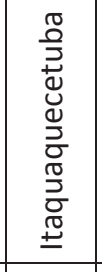 & 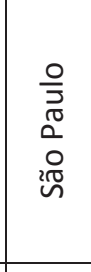 & 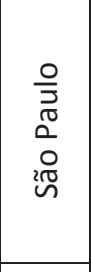 & 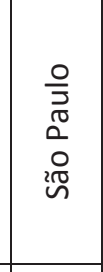 & 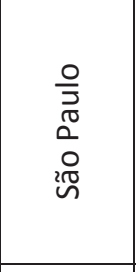 & 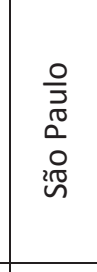 & 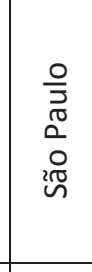 \\
\hline $\begin{array}{l}\overline{0} \\
\overline{\frac{0}{0}} \\
\frac{0}{0} \\
\frac{0}{4}\end{array}$ & $\mid \begin{array}{l}m \\
\tilde{w} \\
\frac{w}{0} \\
w \\
w \\
0 \\
z \\
z\end{array}$ & 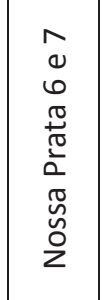 & 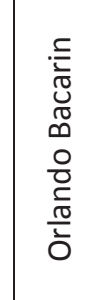 & 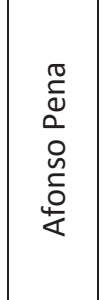 & 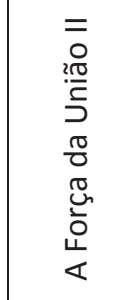 & 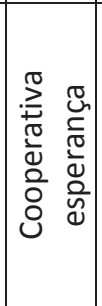 & 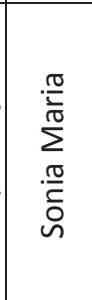 & 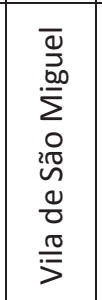 & 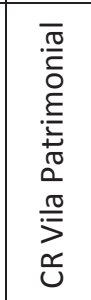 & 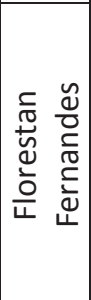 & 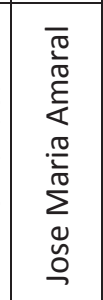 & 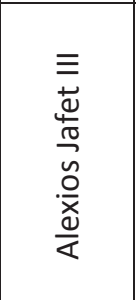 & 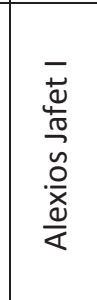 & 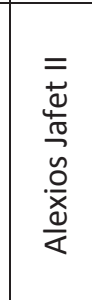 \\
\hline
\end{tabular}


ิㅗ

\begin{tabular}{|c|c|c|c|}
\hline 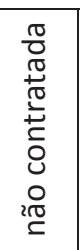 & 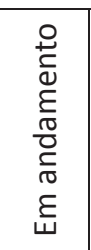 & 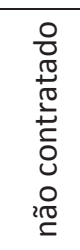 & 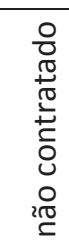 \\
\hline$\frac{\varepsilon}{\bar{n}}$ & $\frac{\varepsilon}{\bar{n}}$ & 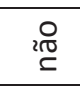 & $\stackrel{2 \pi}{\check{2}}$ \\
\hline 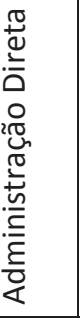 & 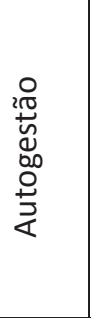 & 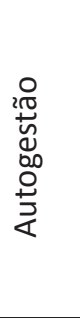 & 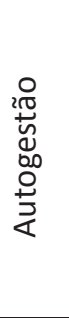 \\
\hline 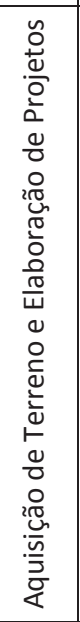 & 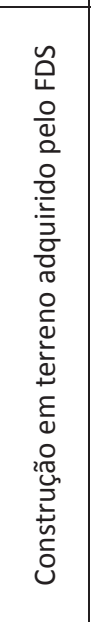 & 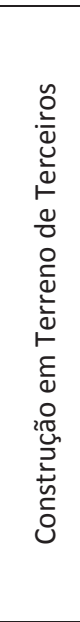 & 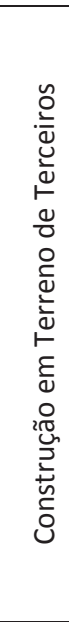 \\
\hline$\sum_{\Sigma}^{山}$ & $\begin{array}{l} \\
\sum_{i}^{u} \\
\Sigma\end{array}$ & $\sum_{\Sigma}^{u}$ & $\sum_{\Sigma}^{u}$ \\
\hline $\begin{array}{l}\frac{c}{0} \\
\frac{0}{\sigma}\end{array}$ & 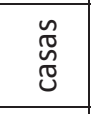 & $\begin{array}{l}\frac{o}{0} \\
\frac{0}{0}\end{array}$ & $\begin{array}{l}\frac{0}{0} \\
\frac{0}{0}\end{array}$ \\
\hline 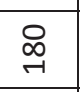 & $\infty$ & $\infty$ & $\stackrel{\circ}{n}$ \\
\hline $\begin{array}{l}\frac{u}{1} \\
\frac{1}{2} \\
\Sigma\end{array}$ & 芯 & 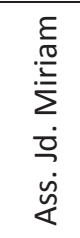 & 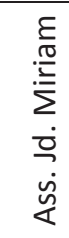 \\
\hline ì & is & in & is \\
\hline 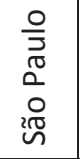 & $\begin{array}{l}\circ \\
\stackrel{\circ}{\bar{N}} \\
\bar{n}\end{array}$ & $\begin{array}{l}\stackrel{\circ}{\bar{N}} \\
\stackrel{\Xi}{n}\end{array}$ & $\begin{array}{l}\stackrel{\circ}{\bar{N}} \\
\stackrel{3}{n}\end{array}$ \\
\hline 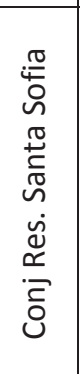 & 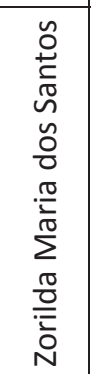 & 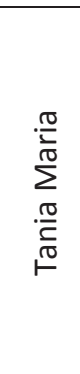 & 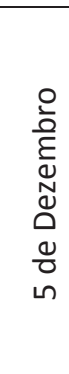 \\
\hline
\end{tabular}




\section{ANEXO 2 - Roteiro para entrevista de caracterização do empreendimento}

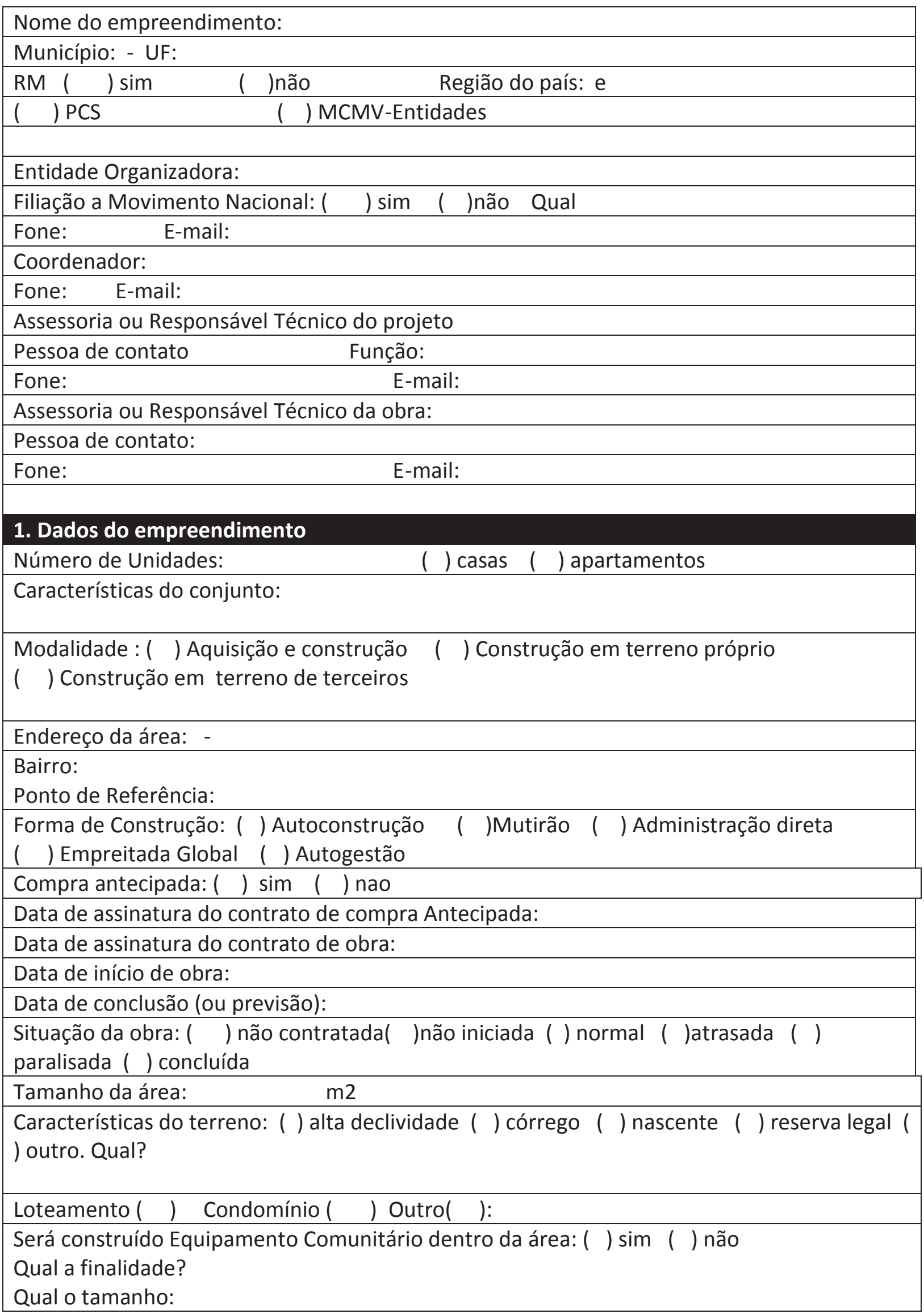




\begin{tabular}{|l|}
\hline Atividade de geração de renda: ( ) sim ( ) não \\
Outro equipamento dentro da área: \\
\hline Empreendimento fechado: ( ) sim ( ) não - Tipo de fechamento: \\
\hline Portaria: ( ) sim ( ) não \\
\hline
\end{tabular}

\section{Forma de obtenção do terreno}

( ) Aquisição pelo programa

( ) Doado pela prefeitura ( )Doado pelo gov. estadual ( ) Doado pela SPU

( ) Doado por terceiros. Quem

( ) Outro

Valor de aquisição da área: Total $\mathrm{R}$ Valor por $\mathrm{m} 2$ :

Densidade: $\quad \mathrm{m} 2 / \mathrm{uh}$

Valor da Fração: R\$

Tempo para a aquisição:

Como encontraram a área:

Quem encontrou? Houve intermediação de corretores?

A prefeitura se envolveu na compra?como?

Apoios obtidos:

Especificar de quem e de que tipo:

Mudança de valor durante a negociação:

Comparação com região / Motivo: ..

Dificuldades encontradas:

Quem arcou com os custos de projeto e documentação

Valor gasto até a contratação:

Quantos terrenos foram analisados antes deste e porque foram descartados.

Observações sobre a obtenção do terreno:

\section{Características Urbanísticas da área}

O terreno é ZEIS（） sim （ )não Tipo de zoneamento:

Incide sobre o terreno outro instrumento do Estatuto da Cidade? IPTU progressivo (); preempção() , outro(): isenção IPTU

Legislação especial para parcelamento do solo? quais as diferenças em relação a legislação geral da cidade?

Infra estrutura existente antes do empreendimento:

$($ ) rede de água ( ) rede de esgoto ( ) energia ( ) drenagem () coleta de lixo ( )pavimentação

Especificar se não houver estes serviços, a que distancia estes serviços estão do empreendimento 


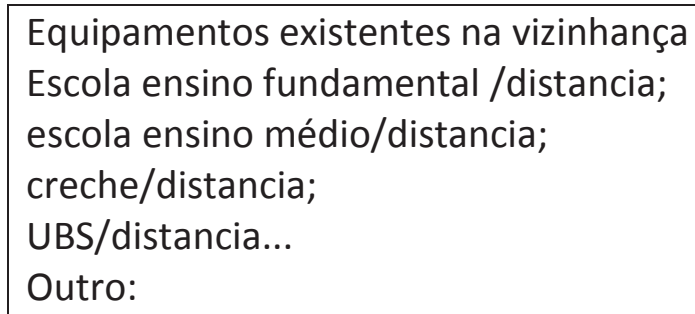

Bairros anteriores de Moradia das famílias do empreendimento:

Condição anterior de moradia das famílias (quantidades)

casa cedida ( casa ou terreno de parentes) \%

Aluguel

Casa em ocupação/favela

Casa própria em outro bairro

\section{Aprovações}

Processo de aprovação do parcelamento:

Tempo:

Dificuldades:

Processo de aprovação da edificação na prefeitura:

Tempo:

Dificuldades:

Processo de aprovação em órgãos ambientais:

Tempo:

Dificuldades:

Rojeto para Fornecimento de água e/ou esgoto

Tempo:

Dificuldades:

Energia Elétrica

Tempo:

Dificuldades:

Outras aprovações: Oficialização da rua

Tempo:

Dificuldades:

Houve necessidade de alteração de alguma lei municipal: ( ) sim ( )não 


\begin{tabular}{|l|}
\hline Houve necessidade de utilização da Lei de regularizaçãod ( ) sim $($ )não \\
\hline Quem ajudou neste processo: \\
\hline Quem atrapalhou este processo: \\
\hline \\
5. Registro \\
\hline Situação da matrícula antes da aquisição: \\
\hline Registro no cartório de imóveis feito em que momento \\
\hline Matrículas individuais feita em que momento: \\
\hline Dificuldades junto ao Rl: \\
\hline
\end{tabular}

\section{Processo de luta}

O terreno foi ocupado pelo movimento em algum momento?

Foi necessária pressão o movimento? Que tipo? Sobre que órgãos?

Obs gerais:

Pessoa entrevistada::

Responsável pelo preenchimento da Ficha:

Data de preenchiimento: 


\section{Anexo 3 - Localização de empreendimentos PCS e MCMV}

Neste anexo, é apresentada a localização de alguns dos empreendimentos pesquisados e, no caso de São Paulo, alguns que não pertence ao universo da pesquisa, mas que nos ajudam na observação.

É importante ressaltar que não se trata apenas de verificar a distância de cada um deles do centro de cada um dos municípios, mas através das referências dadas pelos entrevistados e pelo conhecimento empírico de cada lugar, ter um panorama dessa localização.

\section{São Paulo - SP}

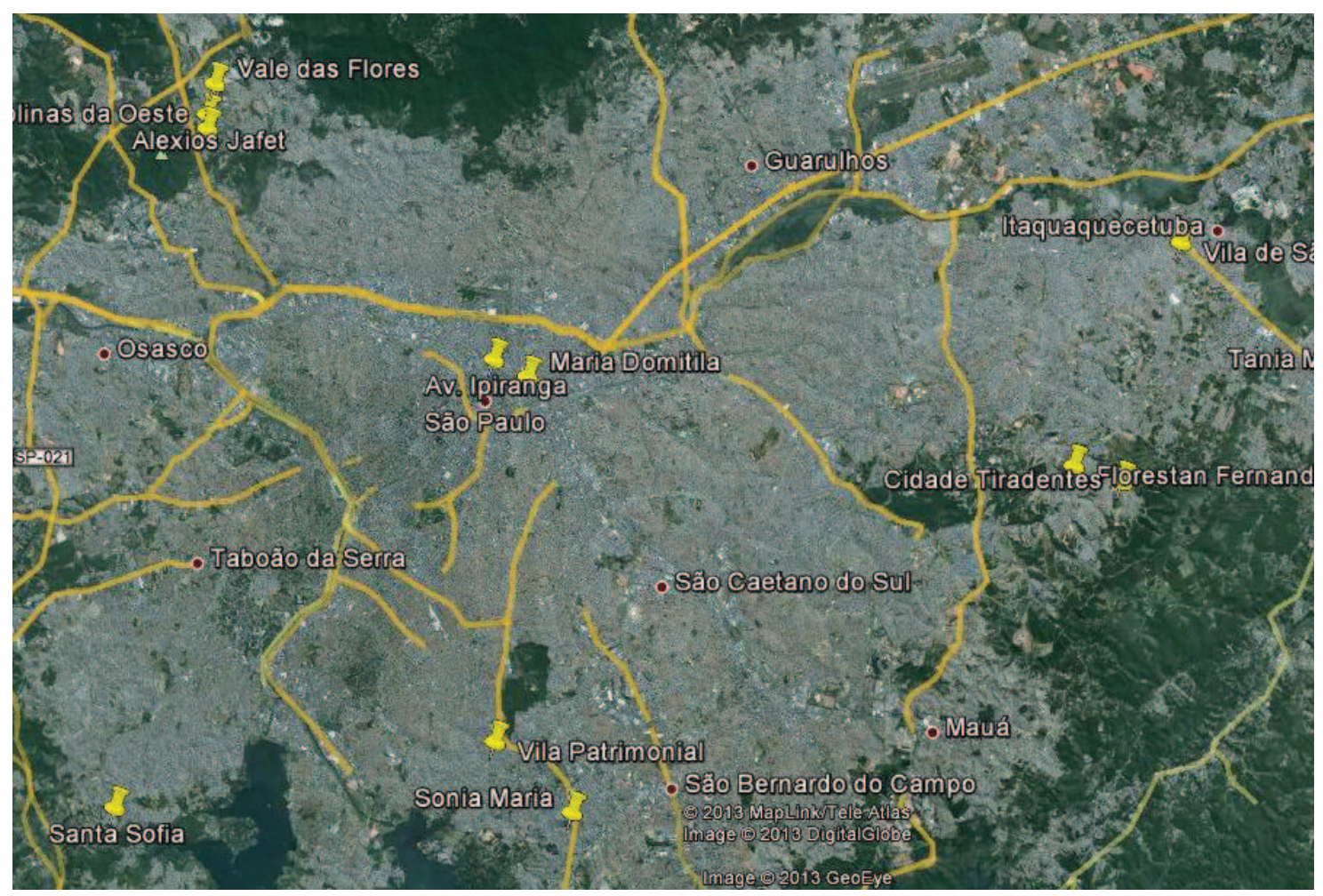

Fonte: Google Earth

No mapa da cidade de São Paulo, estão identificadas 9 áreas que compreendem 12 empreendimentos, com 2.868 unidades. Desses, 3 áreas pertencem ao grupo de empreendimentos pesquisados (Cidade Tiradentes, Av. Ipiranga e Maria Domitila). Também 
aparecem na imagem um empreendimento de Itaquaquecetuba e outro de Diadema, municípios conurbados a São Paulo.

Nota-se claramente a localização periférica da maioria dos empreendimentos, com exceção do Av. Ipiranga e Maria Domitila, não casualmente localizado em terrenos da SPU e INSS, respectivamente que se encontram no centro da cidade. Também o empreendimento Vila Patrimonial, apesar de se localizar a $18 \mathrm{~km}$ do centro, está em bairro popular estruturado e totalmente urbanizado, além de próximo a região de alta renda e serviços de alto padrão ( $8 \mathrm{~km}$ do Brooklin) e a 2,5 km do centro de Diadema.

Na Zona Noroeste, a cerca de $25 \mathrm{~km}$ do centro estão as áreas dos empreendimentos Colinas da Oeste, Alexius Jafet e Vale das Flores na franja periférica da cidade. Esses empreendimentos, no entanto, contam com uma vantagem ao estarem próximo a uma linha de trens urbanos, fazendo que o trajeto até o centro seja de cerca de 50 minutos.

Já os empreendimentos localizados no extremo da Zona Leste, na Cidade Tiradentes, se encontram a cerca de $30 \mathrm{~km}$ do centro, em região conhecida por seus inúmeros conjuntos habitacionais. O trajeto em transporte público até o centro leva cerca de 1 hora e 30 minutos, utilizando o Metrô. A estação de Metrô mais próxima, Itaquera, fica a $12 \mathrm{~km}$ dos empreendimentos, fazendo com que qualquer deslocamento para as áreas de oferta de empregos tome mais de uma hora.

O outro empreendimento localizado na Zona Sul da cidade, Santa Sofia, fica a $28 \mathrm{~km}$ do centro, em região de precário acesso e baixa qualidade do transporte coletivo. 


\section{Salvador - BA}

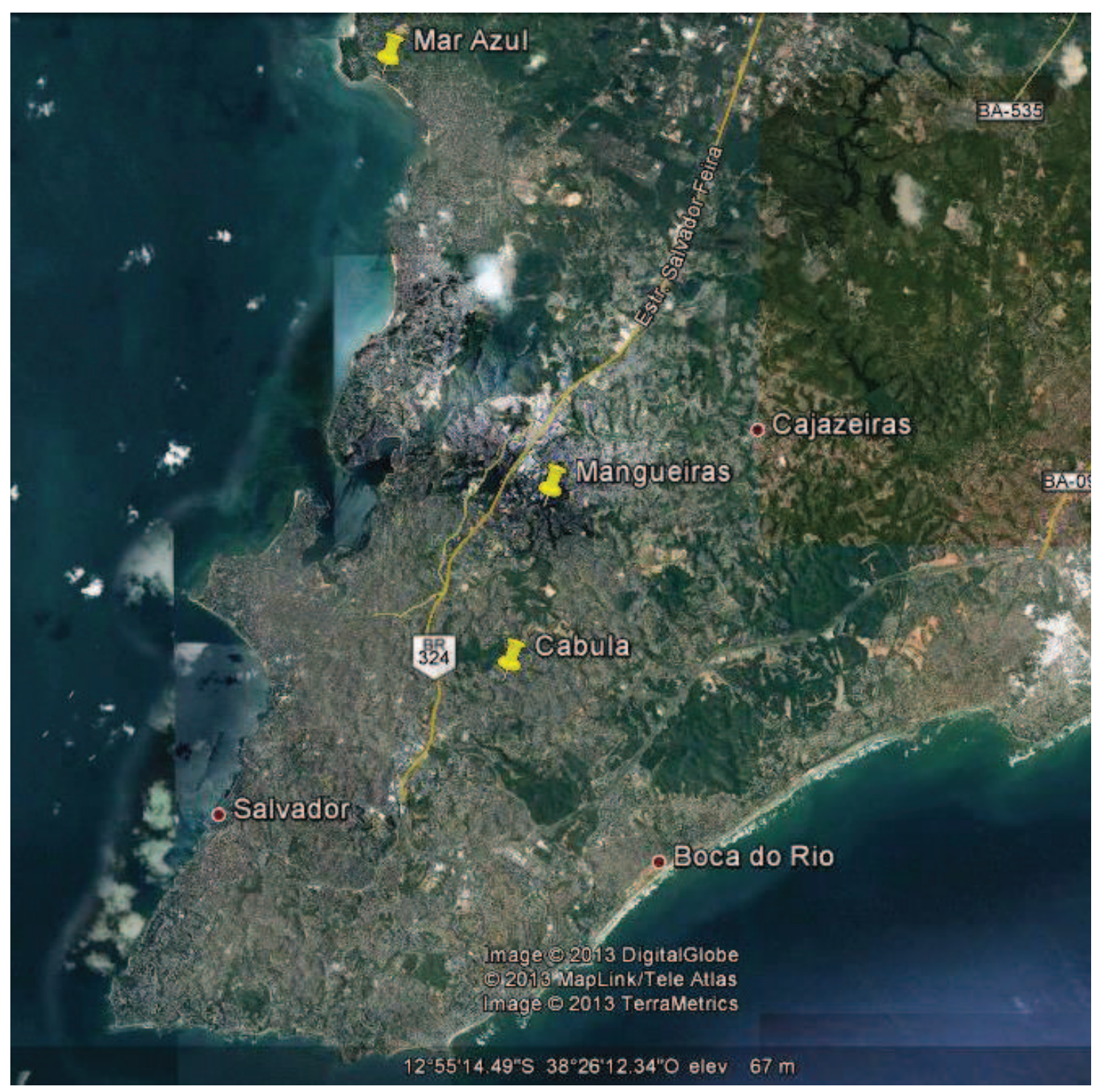

Fonte Google Earth

Em Salvador, destaca-se o empreendimento Vitória da União, localizado no bairro de Cabula, a $12 \mathrm{~km}$ do centro, em uma região de urbanização já consolidada, próxima a equipamentos públicos, comércio e com vasta opção de transporte público.

O empreendimento Mangueiras se encontra a $16 \mathrm{~km}$ do centro em região com infraestrutura em consolidação, mas que tem sido, nos últimos anos, frente de expansão do capital imobiliário para rendas média e alta. O empreendimento se localiza a poucos metros do condomínio provado "Alphaville 2", símbolo de ocupação de alto padrão. 
Já o empreendimento Mar Azul se localiza no extremo do chamado Subúrbio Ferroviário de Salvador, em Paripe, a $21 \mathrm{~km}$ do centro. Trata-se de região de ocupação popular, com o empreendimento localizado em frente à Baía de Todos os Santos, 2 km após o centro do bairro. A região conta com trem urbano a $2 \mathrm{~km}$, mas devido à sua precariedade, o transporte em ônibus é o mais utilizado.

\section{São Luis - MA}

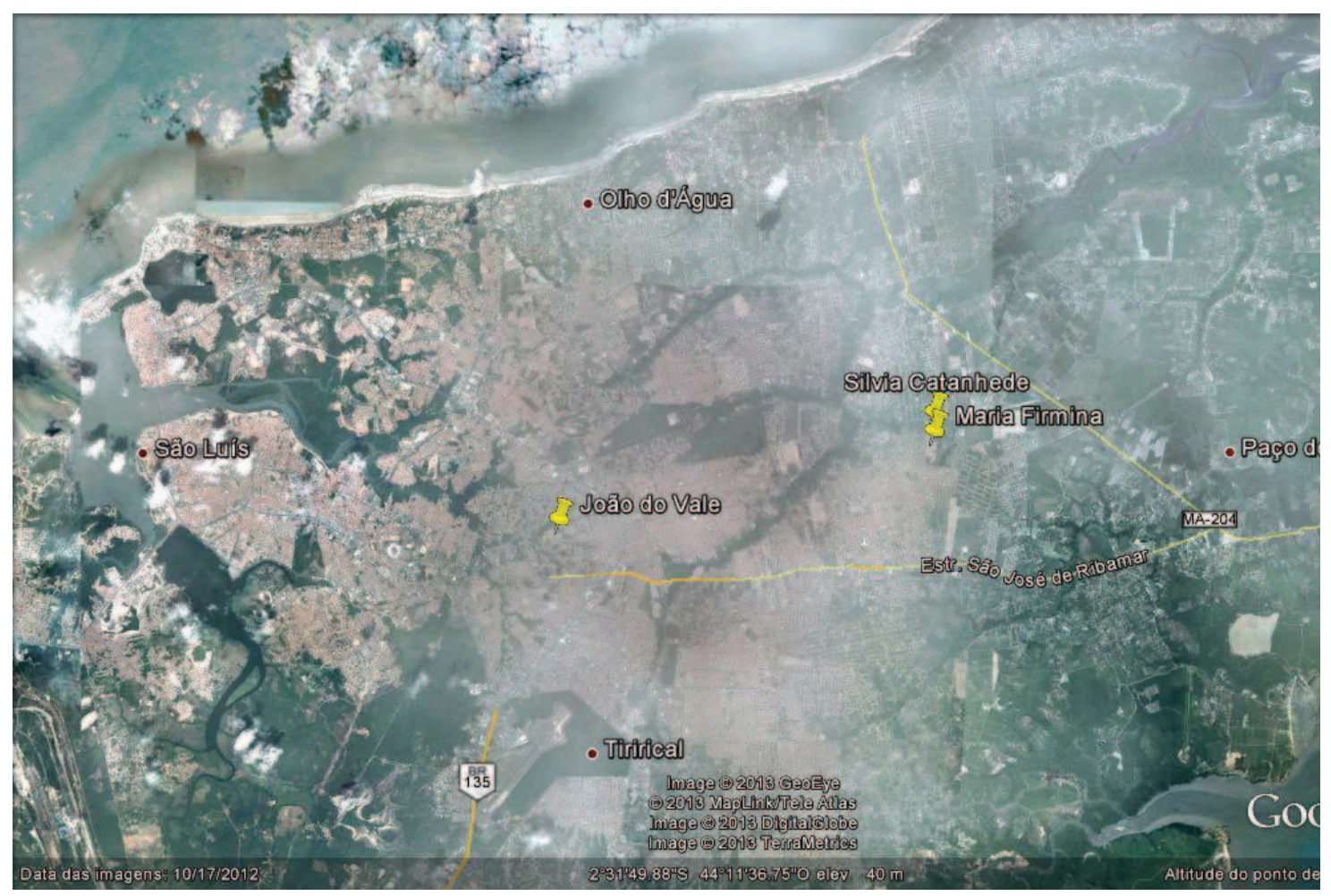

Fonte Google Earth

O empreendimento João do Vale está localizado na periferia consolidada da cidade, há cerca de $12 \mathrm{~km}$ do centro, onde estão concentradas as oportunidades de emprego (majoritamente no setor de serviços). O deslocamento demanda cerca de 40 minutos por meio do transporte coletivo. Os empreendimentos Maria Firmina e Silvia Cantanhede, embora pertençam ao município de Paço do Lumiar, também se relacionam prioritariamente com o centro da capital, de onde distam cerca de $23 \mathrm{~km}$. 


\section{Suzano - SP}

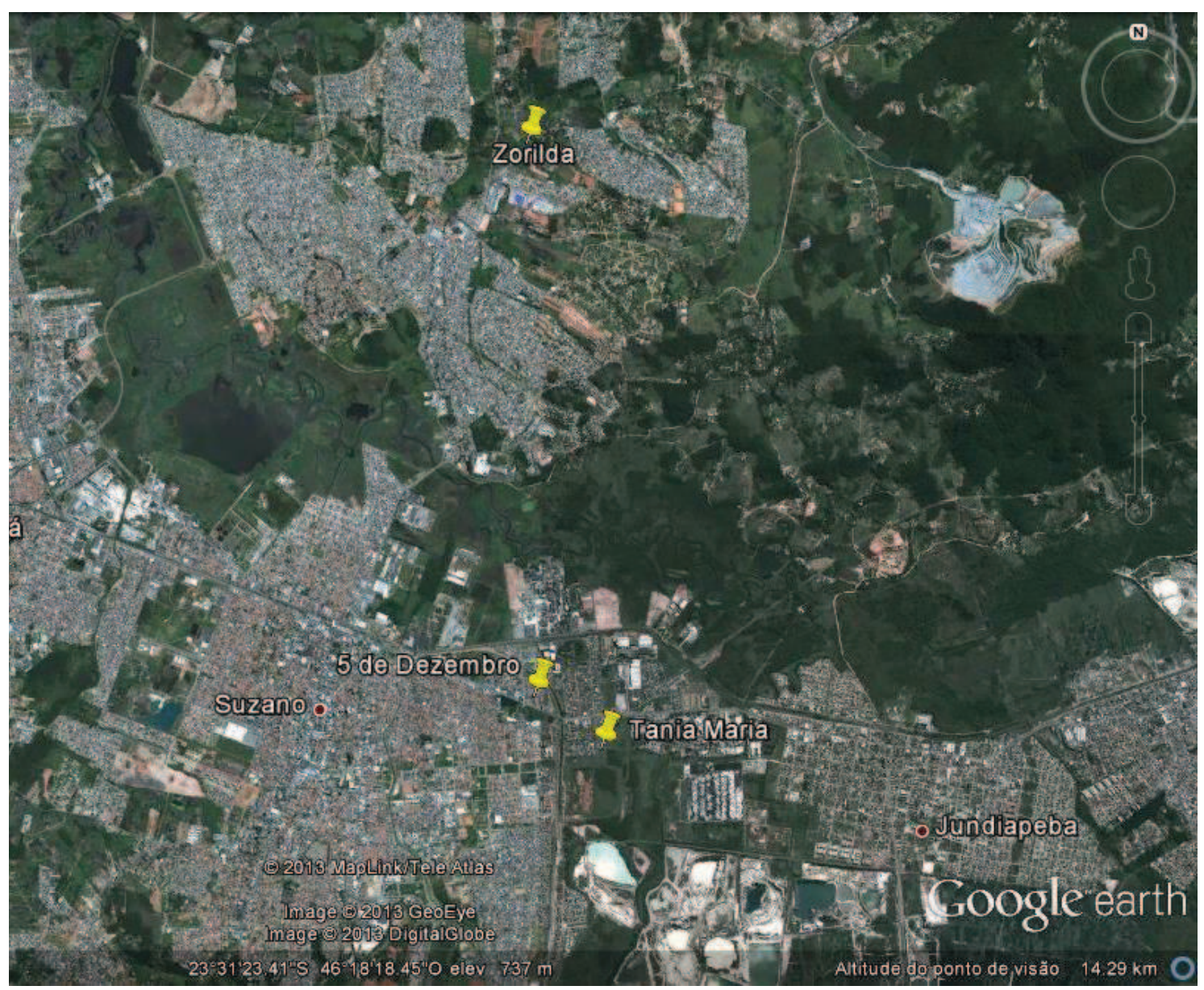

Fonte Google Earth

Este município da Região Metropolitana de São Paulo, conta com um parque industrial próprio, fazendo com que parte da população encontre trabalho no próprio município. No entanto, o crescimento populacional da capital, cuja maior intensidade se dá nas extremidades da cidade, pressiona a região onde estão localizados os empreendimentos. A cidade é ligada à capital por uma linha de trem urbano e o percurso de $45 \mathrm{~km}$ é feito em cerca de 1 hora (Estação da Luz).

Os empreendimentos Tania Maria e Cinco de Dezembro localizam-se em áreas doadas pela Prefeitura Municipal e estão a 4 e a 3,5 km de distância do centro e da estação ferroviária ou 10 minutos de ônibus. São bairros contíguos ao centro da cidade.

Já o empreendimento Zorilda está a pouco mais de $5 \mathrm{~km}$ do centro após um conjunto de bairros populares, em região antes destinada a chácaras e que começa a ser convertido 
em loteamentos e condomínios. Apesar da proximidade com o centro, a infraestrutura viária é precária, fazendo com que o deslocamento leve em torno de 30 minutos até a estação ferroviária.

Alfenas - MG

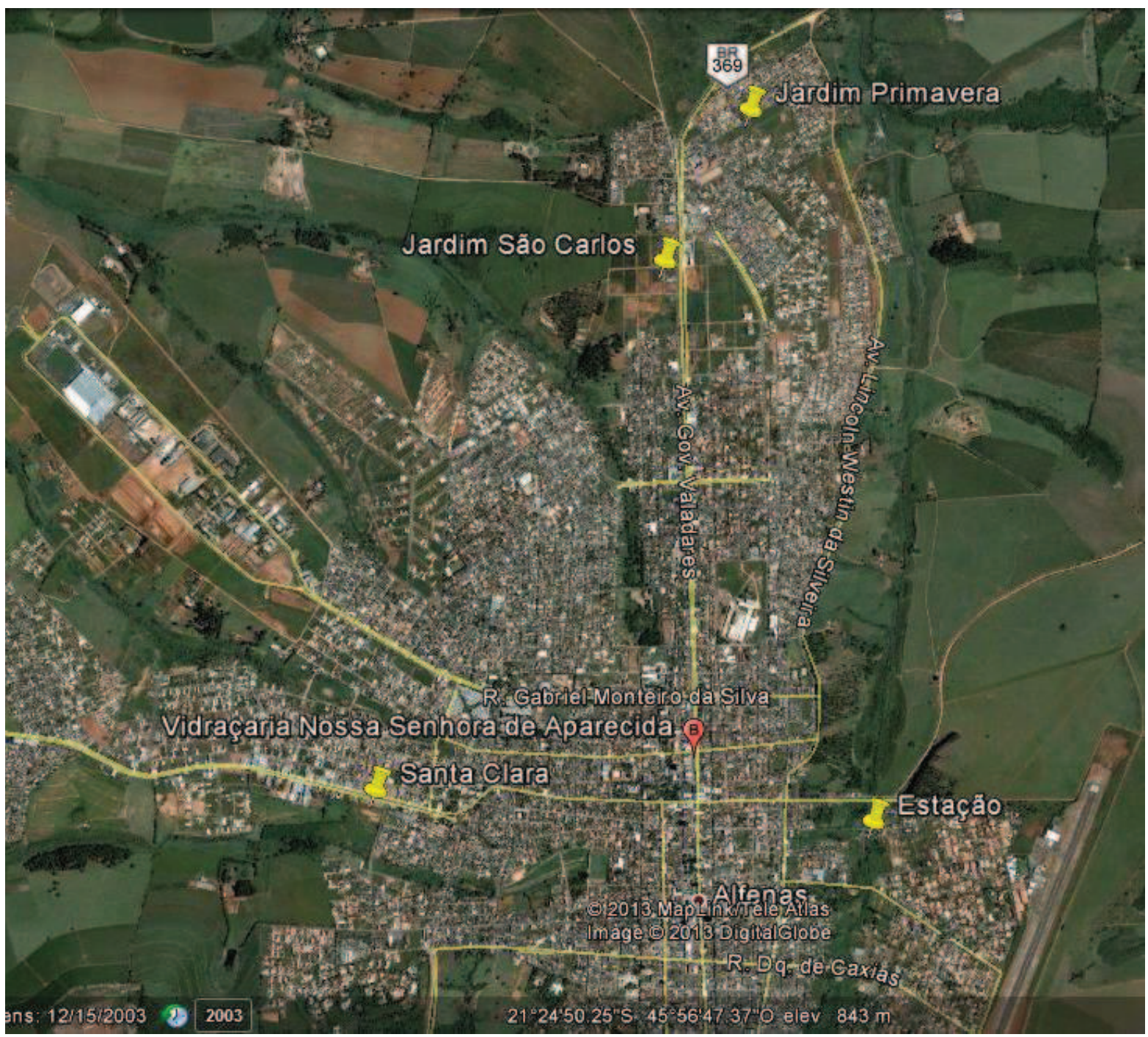

Fonte Google Earth

A cidade está localizada no sul de Minas Gerais, possui população de aproximadamente 74.000 habitantes, segundo os dados do Censo 2010/IBGE. Os empreendimentos estão bem distribuídos e localizados na periferia da cidade, em regiões que são dotadas de razoável infraestrutura urbana. 


\section{ANEXO 4 - ROTEIRO PARA ELABORAÇÃO DO “LAUDO DE VIABILIDADE TÉCNICA DE EMPREENDIMENTOS HABITACIONAIS DE INTERESSE SOCIAL" - PMCMV-E}

\section{Fonte de Recursos: FDS}

Modalidade: Aquisição de terreno pela EO, pagamento de despesas de legalização do terreno e pagamento de assistência técnica para elaboração de projetos

\section{CONDICIONANTES URBANÍSTICOS E AMBIENTAIS}

1.1. Análise legislação municipal:

- Zoneamento;

- Plano diretor;

- Código de obras.

1.2. Análise legislação estadual:

- Proteção combate a incêndios

- Ambiental (área de mananciais e outras)

1.3. Análise legislação federal, em especial:

- Parcelamento

- Resoluções CONAMA e Código Florestal (ocorrência de APP ou vegetação)

2. ÁREA E LOCALIZAÇÃO DO EMPREENDIMENTO (entorno)

2.1. Breve descrição da área de localização do empreendimento, equipamentos públicos e institucionais, infraestrutura urbana, transporte público, comércio e serviços e breve histórico de ocupação do bairro;

2.2. Mapa que localize o empreendimento em relação à cidade e aos equipamentos do entorno;

2.3. Análise da densidade de ocupação e tipologia arquitetônica predominante no entorno;

2.4. Análise do entorno para identificação de potencial de contaminação do terreno (Anexo 2 do Guia de Avaliação do Potencial de contaminação em Imóveis www.cetesb.sp.gov.br - solo - áreas contaminadas) e preenchimento do questionário da CETESB (acesso pelo site), se for o caso; 
2.5. Análise sobre o entorno e terrenos lindeiros sobre existência de linhas de transmissão, torres de celular, cursos d'água, servidão de passagem e outros que podem afetar ou restringir a implantação do empreendimento;

2.6. Indicação das soluções para abastecimento de água e esgotamento sanitário cf. carta de viabilidade das concessionárias.

\section{TERRENO}

3.1. Informar sobre a declividade do terreno, previsão de movimentação de terra, empréstimo e/ou bota-fora de material e necessidade de contenções e obras especiais;

3.2. Análise sobre toda a legislação impactante sobre o terreno e implantação do condomínio ou loteamento;

3.3. Análise da situação do terreno em relação à cota de inundação, no caso de terreno lindeiro a curso ou espelho d'água;

3.4. Breve relato sobre a situação fundiária do terreno.

4. APRESENTAÇÃO DA PROPOSTA

4.1. Caracterizar o empreendimento proposto (infraestrutura, equipamentos comunitários, tipologia arquitetônica, padrão de acabamento, $\mathrm{n}^{\circ}$ de blocos, $\mathrm{n}^{\circ}$ de pavimentos, $\mathrm{n}^{\circ}$ de dormitórios, área útil, área construída, área equivalente, área de APP, área de recuos, áreas non aedificandi,...);

4.2. Ilustrar a descrição do empreendimento com figuras indicativas da implantação e tipologia habitacional

\section{ANÁLISE DA VIABILIDADE ECONÔMICA DO EMPREENDIMENTO}

5.1. Análise dos valores de investimento indicados no QCl, conforme parâmetros abaixo:

5.2. Custo de aquisição do terreno e quota parte por unidade habitacional (UH);

5.3. Custo estimado da unidade habitacional, incluindo BDI/ LDI (lucro e despesas indiretas);

5.4. Custo estimado das soluções de implantação e infraestrutura;

5.5. Custo de elaboração dos estudos e projetos e da assessoria à obra;

5.6. Custo das despesas de legalização;

5.7. Contrapartida: Indicação de parcerias para composição dos valores de investimento ou. contrapartida das famílias (serviços e/ou financeira) 


\section{CONCLUSÃO}

6.1. Devem ser prestadas informações finais e conclusivas sobre a viabilidade do empreendimento e a necessidade da aquisição antecipada do terreno.

6.2. Declarar: "Declaro que o empreendimento apresentado é viável para construção de habitação para população de baixa renda, nos termos das informações prestadas neste Laudo, sobre as quais assumimos total responsabilidade e garantimos sua veracidade e retidão."

6.3. Declarar: "Declaro que os projetos de arquitetura e complementares, urbanístico e de infra-estrutura a serem desenvolvidos no âmbito do PMCMV-Entidades para o empreendimento a ser edificado nesse terreno serão pautados pela boa técnica e atenderão a toda a legislação incidente e normas pertinentes, especialmente:

6.3.1. NBR 9050 - Acessibilidade a edificações, mobiliário, espaços e equipamentos urbanos;

6.3.2. NBR 15575 - Desempenho : Edifícios habitacionais de até 5 pavimentos;

6.3.3. NBR 08036 - Programação de Sondagens para Simples Reconhecimento.

\section{ANEXOS}

7.1. Diretrizes das concessionárias de água, esgoto e energia;

7.2. Relação da legislação incidente (Bibliografia);

7.3. Parecer Ambiental - se for o caso.

7.4. ART de Laudo (atividade técnica 29)

Fonte: Caixa, 2012 